Universidade de São Paulo

Faculdade de Saúde Pública

LIDIANE ALONSO PAIXÃO DOS ANJOS

\title{
ANÁLISE DA GESTÃO DOS CORPOS HÍDRICOS URBANOS DA BACIA HIDROGRÁFICA DO ALTO TIETÊ
}




\section{Universidade de São Paulo Faculdade de Saúde Pública}

LIDIANE ALONSO PAIXÃO DOS ANJOS

Análise da gestão dos corpos hídricos urbanos da Bacia Hidrográfica do Alto Tietê

Dissertação apresentada ao Programa de Pós-Graduação Ambiente, Saúde e Sustentabilidade, da Faculdade de Saúde Pública, da Universidade de São Paulo, para a obtenção do título de Mestre em Ciências.

Orientador: Prof. Dr. José Luiz Negrão Mucci 
É expressamente proibida a comercialização deste documento, tanto na sua forma impressa como eletrônica. Sua reprodução, total ou parcial, é permitida exclusivamente para fins acadêmicos e científicos, desde que na reprodução figure a identificação do autor, título, instituição e ano da dissertação.

\section{Catalogação da Publicação}

Biblioteca/CIR: Centro de Informação e Referência em Saúde Pública Faculdade de Saúde Pública da Universidade de São Paulo

Anjos, Lidiane Alonso Paixão

Análise da gestão dos corpos hídricos da Bacia Hidrográfica do Alto Tietê. Prof. Dr. José Luiz Negrão Mucci (orientador) - São Paulo - 2016.

$\mathbf{N}^{\circ}$ fls. 224 f.: il.

Dissertação (Mestrado) - Universidade de São Paulo, 2017

1. rios urbanos. 2. gestão de recursos hídricos. 3. legislação ambiental. 4. Comitê da Bacia Hidrográfica do Alto Tietê. 5. saúde pública. 
ANJOS, Lidiane Alonso Paixão, Análise da gestão dos corpos hídricos da Bacia Hidrográfica do Alto Tietê Faculdade de Saúde Pública da Universidade de São Paulo, São Paulo, 2017. 


\section{FOLHA DE APROVAÇÃO (DISSERTAÇÃO)}

\section{ANJOS, Lidiane Alonso Paixão}

Análise da gestão dos corpos hídricos da Bacia Hidrográfica do Alto Tietê. Dissertação apresentada ao Programa de Pós-Graduação Ambiente, Saúde e Sustentabilidade, da Faculdade de Saúde Pública, da Universidade de São Paulo, para a obtenção do Título de Mestre em Ciências.

Aprovado em:

\section{BANCA EXAMINADORA}

Prof. Dr. José Luiz Negrão Mucci (orientador)

Instituição: Universidade de São Paulo - USP

Julgamento:

Assinatura:

Prof. Dr. Leandro Luiz Giatti

Instituição: Universidade de São Paulo - USP

Julgamento:

Assinatura:

Profa. Dra. Ana Lúcia Brandimarte

Instituição: Universidade de São Paulo - USP

Julgamento:

Assinatura:

Prof. Dr. Ricardo de Sousa Moretti

Instituição: Universidade Federal do ABC - UFABC

Julgamento: Assinatura: 


\section{AGRADECIMENTOS}

Primeiramente agradeço aos meus pais, por me apoiarem nesta jornada e me darem todo o suporte necessário e não mediram esforços para que eu chegasse até esta etapa da minha vida. Assim como minhas irmãs e meu irmão, que sempre acreditaram em minha capacidade.

A Universidade de São Paulo e todo corpo docente, direção e administração, que realizam seu trabalho com tanto amor e dedicação, trabalhando incansavelmente para que nós, alunos, possamos contar com um ensino de extrema qualidade.

Em especial, ao professor José Luiz Negrão Mucci, pela paciência na orientação, dedicação, ensinamentos e esforço para que eu pudesse ter confiança e segurança na realização deste trabalho.

A todos os professores que me auxiliaram ao longo do processo nas bancas de qualificação e defesa para que eu pudesse melhorar o texto e realizar um trabalho mais completo.

Meus sinceros agradecimentos a todos que direta ou indiretamente fizeram parte da minha formação. 
OS RIOS

Os rios que eu encontro

vão seguindo comigo.

Rios são de água pouca,

em que a água sempre está por um fio.

Cortados no verão

que faz secar todos os rios.

Rios todos com nome

e que abraço como a amigos.

uns com nome de gente, outros com nome de bicho, uns com nome de santo,

Muitos só com apelido.

Mas todos como a gente

que por aqui tenho visto:

a gente cuja vida

se interrompe quando os rios.

(João Cabral de Melo Neto) 


\section{RESUMO}

ANJOS, L. A. P. Análise da gestão dos corpos hídricos urbanos da Bacia Hidrográfica do

Alto Tietê. 2017. 224 f. Dissertação (Mestrado) - Faculdade de Saúde Pública, Universidade de São Paulo, São Paulo, 2017.

Diante das modificações ocorridas com o crescimento urbano ao longo dos anos e a consequente falta de saneamento básico observada no início deste crescimento, a degradação dos rios e córregos da Região Metropolitana de São Paulo foram devastadoras para a sua qualidade, trazendo desconforto e doenças de veiculação hídrica para a população do entorno. Este projeto tem por objetivo analisar como os corpos d'água que não possuem relevância para o abastecimento e que estão localizados na Bacia do Alto Tietê estão sendo tratados pela legislação e por seus gestores, compilando as ações tomadas que favorecem a despoluição dos mesmos. Desenvolveu-se uma pesquisa qualitativa de estudo de caso, com caráter exploratório a partir de dados fornecidos pelo Comitê de Bacia Hidrográfica do Alto Tietê e dados secundários. Conclui-se que apesar de ser discutido dentro do Comitê, os corpos hídricos inseridos na Região Metropolitana de São Paulo não possuem grande importância, tendo o Comitê assuntos prioritários, como abastecimento, assim como a destinação de recursos indicados e aprovados pelo FEHIDRO e os investimentos da SABESP.

Palavras-chave: rios urbanos, gestão de recursos hídricos, legislação ambiental, Comitê da Bacia Hidrográfica do Alto Tietê. 


\section{ABSTRACT}

ANJOS, L. A. P. Analysis of the management of the urban water bodies of AltoTietê watershed. 2017. 224 f. Dissertação (Mestrado) - Faculdade de Saúde Pública, Universidade de São Paulo, São Paulo, 2017.

In the face of the changes that have occurred with urban growth over the years and the consequent lack of basic sanitation observed at the beginning of this growth, the degradation of the rivers and water streams of the São Paulo Metropolitan Area were devastating to its quality, bringing discomfort and waterborne diseases of circulation for the surrounding population. The objective of this project is to analyze how the water bodies among those that do not have relevance for the supply and that are located in the Alto Tietê Watershed are being treated by the legislation and its managers, compiling the actions that were taken to favor the depollution of those specific kind of water body. A qualitative study of a case study was developed, with an exploratory character based on data provided by the Committee of the Alto Tietê Watershed and secondary data. It was concluded that, despite being discussed within the Committee, the water bodies inserted in the São Paulo Metropolitan Region are not of great importance, with the Committee having priority subjects, such as supply, as well as the allocation of resources indicated and approved by FEHIDRO and investments of SABESP.

Key words: urban rivers, water resources management, environmental legislation, Alto Tietê Watershed Committee. 


\section{LISTA DE SIGLAS E ABREVIATURAS}

ABRH - Associação Brasileira de Recursos Hídricos

ANA - Agência Nacional de Águas

APP - Áreas de Preservação Permanente

APRM - Área de Proteção e Recuperação de Mananciais

BH-AT - Bacia Hidrográfica do Alto Tietê

BID - Banco Interamericano de Desenvolvimento

BNDES - Banco Nacional de Desenvolvimento Econômico e Social

CATI - Coordenadoria de Assistência Técnica Integral

CBH - Comitê de Bacia Hidrográfica

CBH-AT - Comitê de Bacia Hidrográfica Alto Tietê

CERH - Conselho Estadual de Recursos Hídricos

CETESB - Companhia Ambiental do Estado de São Paulo

CF/88 - Constituição Federal de 1988

CNRH - Conselho Nacional de Recursos Hídricos

COFEHIDRO - Conselho de Orientação de Fundo Estadual de Recursos Hídricos

CONSEMA - Conselho Estadual de Meio Ambiente

CONESAN - Conselho Estadual de Saneamento

CORHI - Comitê Coordenador do Plano Estadual de Recursos Hídricos

CRH - Conselho Estadual de Recursos Hídricos

CT - Câmara Técnica

CTGI - Câmara Técnica de Gestão de Investimentos

CTMH - Câmara Técnica de Monitoramento Hidrológico

CTPA - Câmara Técnica de Planejamento e Articulação

DAEE - Departamento de Águas e Energia Elétrica

DBO - Demanda Bioquímica de Oxigênio

EIA/RIMA - Estudo de Impacto Ambiental/ Relatório de Impacto Ambiental

ETE - Estação de Tratamento de Esgoto

FABHAT - Fundação Agência da Bacia Hidrográfica do Alto Tietê

FEBEM - Fundação Centro de Atendimento Socioeducativo ao Adolescente

FEHIDRO - Fundo Estadual de Recursos Hídricos

FUSP - Fundação de apoio à Universidade de São Paulo 
GOD - Groundwater occurrence, Overall lithology of the unsaturated zone, Depth to the water table

GT - Grupo de Trabalho

GTGD - Grupo de Trabalho de Gestão da Demanda

IAP - Índice de Qualidade de Águas Brutas para Fins de Abastecimento Público

IBGE - Instituto Brasileiro de Geografia e Estatística

IET - Índice de Estado Trófico

IGR - Índice de Qualidade de Gestão de Resíduos Sólidos

IPT - Instituto de Pesquisas Tecnológicas do Estado de São Paulo

IPRS - Índice Paulista de Responsabilidade Social

ISTO - Índice de Substâncias Tóxicas e Organolépticas

IQA - Índice de Qualidade de Água

IQC - Índice de Qualidade de Usinas de Compostagem

IQR - Índice de Qualidade de Aterro de Resíduos

IVA - Índice de Preservação da Vida Aquática

MMA - Ministério do Meio Ambiente

OD - Oxigênio dissolvido

OMS - Organização Mundial da Saúde

PCJ - rios Piracicaba, Capivari e Jundiaí

PDPA - Plano de Desenvolvimento e Proteção Ambiental

PDMAT - Plano de Macrodrenagem da Bacia Alto Tietê

PFTHM - Potencial de Formação de Trihalometanos

PLANASA - Plano Nacional de Saneamento Básico

PMSP - Prefeitura Municipal de São Paulo

PND - Plano Nacional de Desenvolvimento

PNRH - Política Nacional de Recursos Hídricos

RMSP - Região Metropolitana de São Paulo

SABESP - Companhia de Saneamento Básico do Estado de São Paulo

SEADE - Fundação Sistema Estadual de Análise de Dados

SEMA - Secretaria Especial do Meio Ambiente

SER - Society for Ecological Restoration

SigRH - Sistema Integrado de Gerenciamento de Recursos Hídricos

SIM - Sistema Integrado Metropolitano 
SNGRH - Sistema Nacional de Gerenciamento de Recursos Hídricos

SNIS - Sistema Nacional de Informações sobre Saneamento

SRHSO - Secretaria de Recursos Hídricos, Saneamento e Obras

SRHU - Secretaria de Recursos Hídricos e Ambiente Urbano

UGRHI - Unidades de Gerenciamento de Recursos Hídricos

UGRHI-06 - Unidade de Gerenciamento de Recursos Hídricos Alto Tietê

UNCED - Conferência das Nações Unidas 


\section{LISTA DE QUADROS}

Quadro 1 - Composição do Conselho Estadual de Recursos Hídricos. 49

Quadro 2 - Densidade demográfica, população total e grau de urbanização dos municípios da Bacia Hidrográfica do Alto Tietê.

Quadro 3 - Situação dos Planos de Saneamento nos municípios da Bacia Hidrográfica do Alto Tietê.

Quadro 4 - Índice de Gestão de Resíduos Sólidos na Bacia Hidrográfica do Alto Tietê - 2012 ........ 72

Quadro 5 - Lista de projetos indicados para recebimento de recursos financeiros do FEHIDRO no ano 1996

Quadro 7 - Lista de alguns projetos indicados para recebimento de recursos financeiros do FEHIDRO no ano 2002 com recursos de 2001. 100

Quadro 8 - Lista de alguns projetos indicados para recebimento de recursos financeiros do FEHIDRO do ano 2003. 101

Quadro 9 - Lista de alguns projetos desconsiderados pelo COFEHIDRO e homologados para o exercício de 2004.

Quadro 10 - Lista de alguns projetos desconsiderados pelo COFEHIDRO e homologados para o exercício de 2004. 103

Quadro 11 - Lista de alguns projetos indicados para recebimento de recursos financeiros do FEHIDRO do ano 2005. 104

Quadro 12 - Lista de alguns projetos indicados para recebimento de recursos financeiros do FEHIDRO do ano 2009. 108

Quadro 13 - Lista de alguns projetos indicados para recebimento de recursos financeiros do FEHIDRO do ano 2011

Quadro 14 - Lista de alguns projetos indicados para recebimento de recursos financeiros do FEHIDRO do ano 2012.

Quadro 15 - Lista de alguns projetos indicados para recebimento de recursos financeiros do FEHIDRO do ano 2014.

Quadro 16 - Lista de alguns projetos indicados para recebimento de recursos financeiros do FEHIDRO do ano 2016, em processo de análise.

Quadro 17 - Investimentos da SABESP em 2016. 


\section{LISTA DE TABELAS}

Tabela 1 - População Total e Taxas de Crescimento Populacional - Estado de São Paulo, Região Metropolitana de São Paulo e Município de São Paulo - 1970 a 2000. 28

Tabela 2 - Mortalidade por doenças infecciosas ( $\mathrm{n}^{\circ}$ absoluto e coeficiente / 100.000) no Município de São Paulo, 1901, 1960 e 2000. 37

Tabela 3 - Percentual de coleta e tratamento de esgoto nos municípios que operam seus sistemas de esgotamento sanitário, em 2015

Tabela 4 - Distribuição porcentual das categorias do IQA na Bacia Hidrográfica do Alto Tietê em 2015 77

Tabela 5 - Distribuição porcentual das categorias do IVA na Bacia Hidrográfica do Alto Tietê em 2015 78

Tabela 6 - Médias anuais do IAP na Bacia Hidrográfica do Alto Tietê, em 2015. 79

Tabela 7 - Porcentual do Índice de Estado Trófico na Bacia Hidrográfica do Alto Tietê em 2015.... 80 


\section{LISTA DE FIGURAS}

Figura 1 - Crescimento demográfico por área de ponderação da Região Metropolitana de São Paulo, entre os anos 1991 a 2000.

Figura 2 - Crescimento demográfico por área de ponderação da Região Metropolitana de São Paulo, entre os anos 2000 a 2010.

Figura 3 - Estrutura do Sistema Nacional de Gerenciamento de Recursos Hídricos. 46

Figura 4 - Divisão do Estado de São Paulo das Unidades de Gerenciamento de Recursos Hídricos.. 48

Figura 5 - Estrutura do Comitê de Bacia Hidrográfica do Alto Tietê. 56

Figura 6 - Hidrografia da Bacia do Alto Tietê. 58

Figura 7 - Subcomitês da Bacia do Alto Tietê. 59

Figura 8 - Sistema de abastecimento da Região Metropolitana de São Paulo 68

Figura 9 - Sistema de Esgotamento Sanitário da Região Metropolitana de São Paulo. 71

Figura 10 - Porcentagem de domicílios por setor censitário com lixo coletado na Bacia Hidrográfica do Alto Tietê e RMSP em 2010

Figura 11- Índice de Qualidade de Aterro de Resíduos na Bacia Hidrográfica do Alto Tietê - 2015.75

Figura 12 - Localização dos pontos de monitoramento da CETESB, em 2015. 81

Figura 13 - Índice de Qualidade de Água no Estado de São Paulo por bacia hidrográfica em 2015. . 82

Figura 14 - Índice de Qualidade de Proteção da Vida Aquática nas águas da Bacia Hidrográfica do Alto Tietê em 2015

Figura 15 - Índice de Qualidade de Águas Brutas para Fins de Abastecimento Público da Bacia Hidrográfica do Alto Tietê em 2015.

Figura 16 - Média anual do Índice de Estado Trófico da Bacia Hidrográfica do Alto Tietê em 2015.85

Figura 17 - Mapa de Recarga Potencial dos aquíferos da Bacia Hidrográfica do Alto Tietê. 88

Figura 18 - Pontos de monitoramento de qualidade das águas subterrâneas da Bacia Hidrográfica do Alto Tietê em 2015 .

Figura 19 - Mapa de Vulnerabilidade Natural à Contaminação de Aquífero da Bacia Hidrográfica do Alto Tietê - Método GOD. 90

Figura 20 - Mapa de áreas críticas integradas da Bacia Hidrográfica do Alto Tietê 91 


\section{LISTA DE GRÁFICOS}

Gráfico 1 - População no município de São Paulo e na Região Metropolitana de São Paulo (RMSP) nos anos 1991, 2000, 2010 e 2015.

Gráfico 2 - Porcentagem de crescimento demográfico no município de São Paulo e na Região Metropolitana de São Paulo (RMSP) entre os anos de 1991 - 2000, 2000 - 2010 e 2010 - 2015...... 30

Gráfico 3 - Porcentagem dos recursos disponibilizados pelo FEHIDRO por Comitê de Bacia

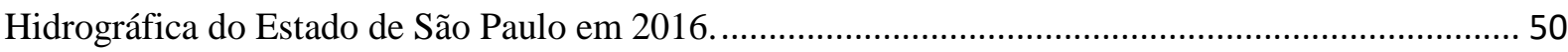

Gráfico 4 - Porcentagem de municípios por grupo do IPRS - ano base 2012 ................................. 62 


\section{SUMÁRIO}

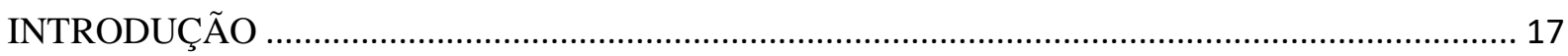

Problematização da pesquisa.................................................................................................. 19

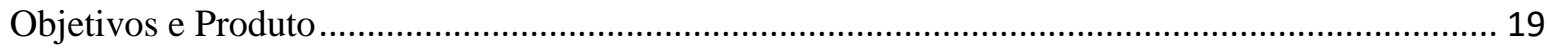

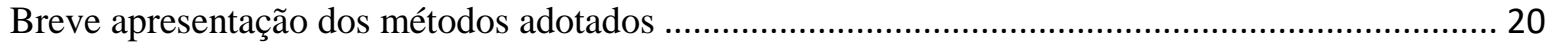

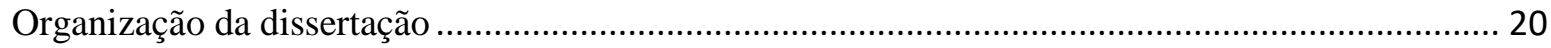

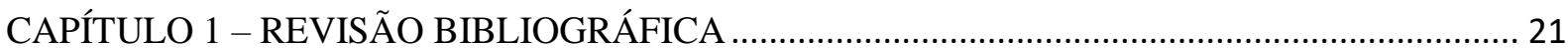

1.1. CRESCIMENTO URBANO DO MUNICÍPIO E DA REGIÃO METROPOLITANA DE

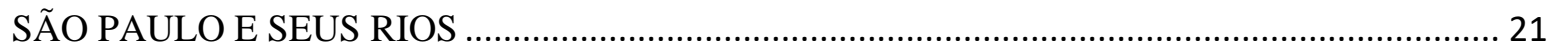

1.1.1. SURGIMENTO DO MUNICÍPIO DE SÃO PAULO …............................................. 21

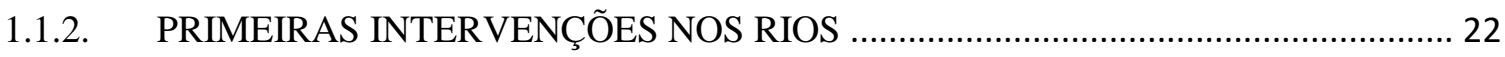

1.1.3. RETIFICAÇÃO DOS RIOS E CONSTRUÇÃO EM FUNDO DE VALE ................... 23

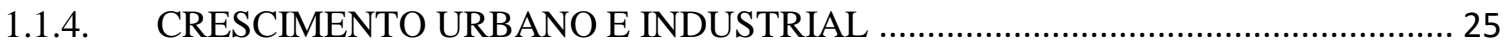

1.1.5. A REGIÃO METROPOLITANA DE SÃO PAULO ..................................................... 29

1.1.6. CONSEQUÊNCIAS DO MODELO DE CRESCIMENTO DO MUNICÍPIO.............. 33

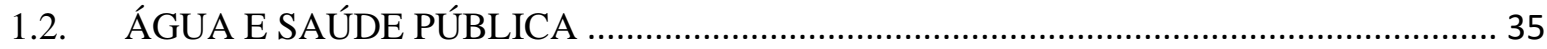

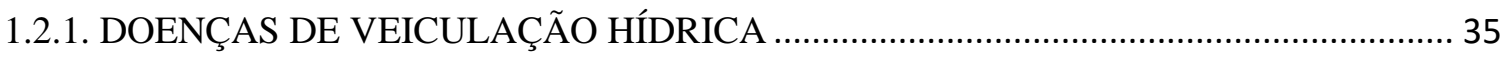

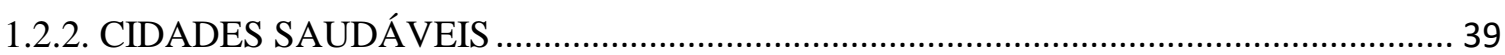

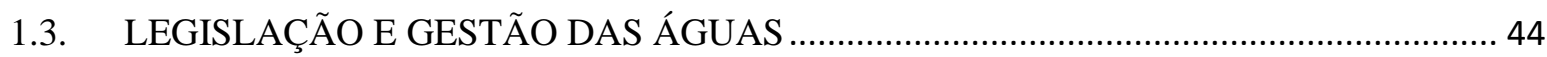

1.3.1 LEGISLAÇÃO E GOVERNANÇA DOS RECURSOS HÍDRICOS NO BRASIL ............. 44

1.3.2 LEGISLAÇÃO E GESTÃO DOS RECURSOS HÍDRICOS NO ESTADO DE SÃO

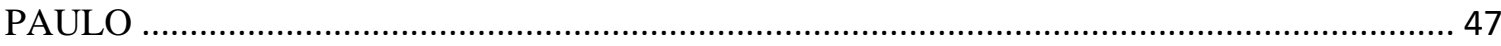

CAPITULO 2 - ESTUDO DE CASO - BACIA HIDROGRÁFICA DO ALTO TIETÊ ..................... 53

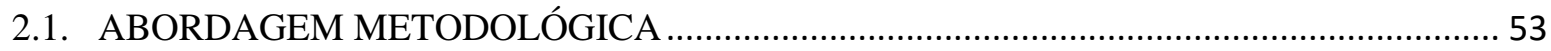

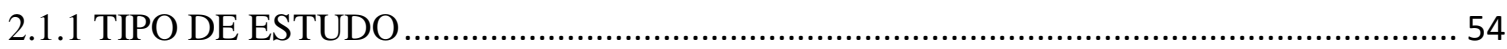

2.1.2 DELIMITAÇÃO DA PESQUISA ............................................................................... 54

2.2. ASPECTOS GERAIS DA BACIA HIDROGRÁFICA DO ALTO TIETÊ................................ 55

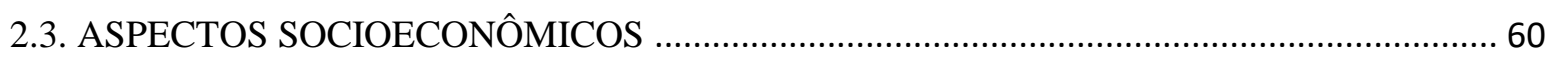

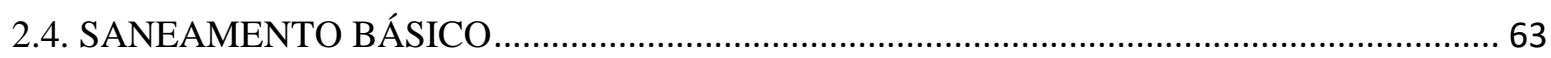

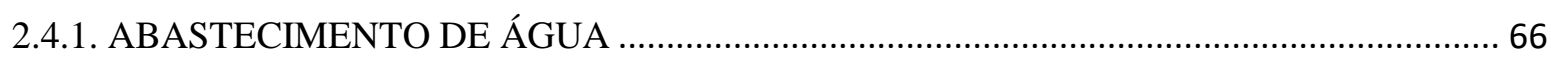

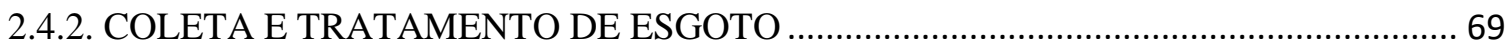

2.4.3. COLETA E DESTINAÇÃO DE RESÍDUOS SÓLIDOS......................................................71 


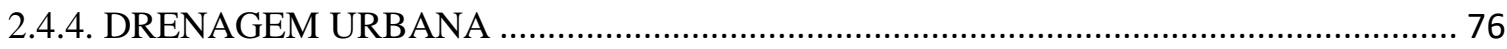

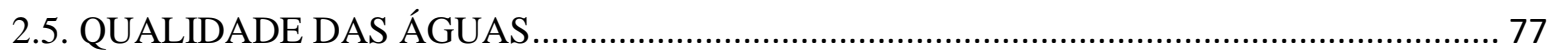

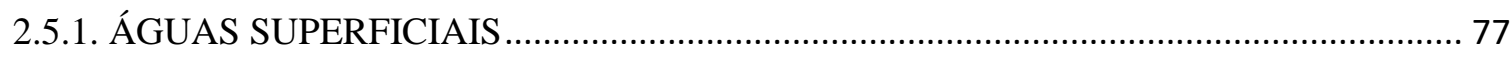

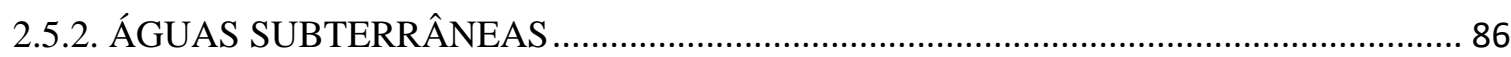

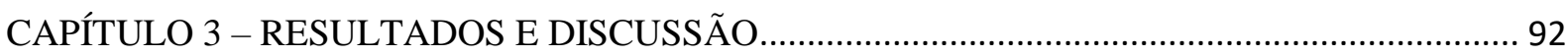

3.1. ANÁLISE DE ATAS E DELIBERAÇÕES DO CBH-AT …............................................. 92

3.2. ALGUMAS INICIATIVAS NA REGIÃO METROPOLITANA DE SÃO PAULO............... 116

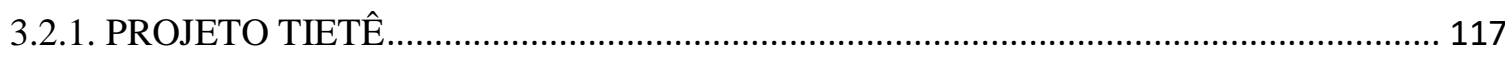

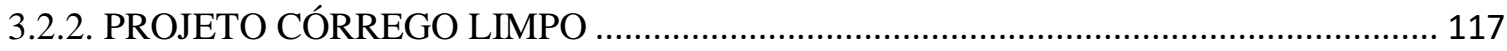

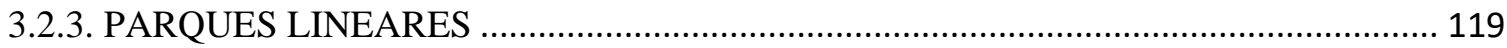

3.3 O COMITÊ DA BACIA HIDROGRÁFICA DO ALTO TIETÊ, O FEHIDRO E A

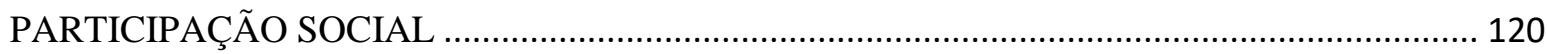

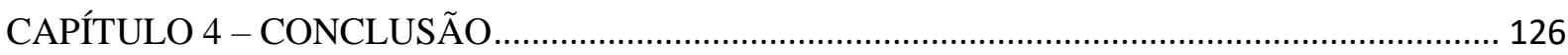

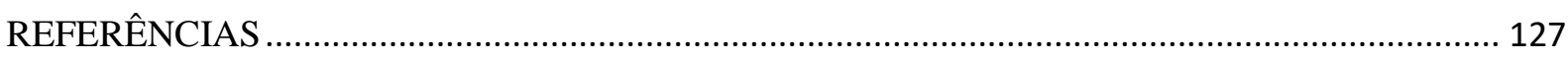

ANEXO A - Síntese das Atas do Comitê de Bacia Hidrográfica Alto Tietê ....................................... 143

ANEXO B - Deliberações do Comitê da Bacia Hidrográfica Alto Tietê ........................................... 169

ANEXO C - Síntese de projetos aprovados para recebimento de recursos financeiros do FEHIDRO 


\section{INTRODUÇÃO}

Os problemas de poluição dos rios e córregos urbanos estão se desenvolvendo na Região Metropolitana de São Paulo (RMSP) desde o início de sua expansão no final do século XIX e início do século XX até os dias atuais. Esta problemática impossibilita a utilização destes corpos hídricos para diversos fins, além de torná-los uma fonte de doenças de veiculação hídrica. CUNHA (2003, p. 224) expõe alguns impactos da seguinte forma:

\footnotetext{
Os desmatamentos indevidos, não controlados pela legislação, e o crescimento de áreas urbanas sem as necessárias condições de manutenção de áreas verdes, para permitir o equilíbrio do ciclo hidrológico, sem as mínimas condições de saneamento (lixo, sedimentos, esgoto), são exemplos de impactos indiretos, oriundos da bacia de drenagem e que causam a degradação dos canais.

Outra forma de degradação do canal relaciona-se à participação direta dos canais por meio da atividade mineradora (alúvios) e de obras de engenharia, como a canalização (retificação, alargamento e aprofundamento do canal), barramentos para controle de vazão e construção de pontes e diques artificiais.
}

O mesmo trabalho menciona ainda o acréscimo aos problemas de poluição dos rios provindos do ambiente urbano devido a disposição incorreta dos resíduos sólidos.

Antes mesmo da acelerada expansão observada na cidade de São Paulo, os rios paulistanos já sofriam com as modificações feitas em sua estrutura, como se pode atestar pela cobertura completa da superfície do córrego Saracura no ano de 1906, fato favorecido pelo crescimento urbano e industrial, assim como foram feitas no século XIX a retificação dos trajetos e a abertura de canais nos rios Tamanduateí e Tietê, devido à expansão de epidemias que se alastravam como febre amarela* e febre tifoide (FIORAVENTI, 2013). Estas doenças de veiculação hídrica, assim como as parasitoses intestinais, por exemplo, são consequências do crescimento urbano sem as mínimas condições de saneamento e conscientização da população sobre a disposição dos seus resíduos e dejetos.

YASSUDA (1993) cita os benefícios econômicos e sociais advindos da água a partir da sua preservação para abastecimento, recreação, esportes aquáticos, agricultura, processos industriais e transporte, além dos seus malefícios quando tratada de forma incorreta, podendo causar problemas de saúde à população do entorno devido a enchentes e proliferação de doenças.

\footnotetext{
"No século XIX acreditava-se que a água estagnada com dejetos ocasionava casos de febre amarela. Entretanto, em 1903 foi comprovado que a doença é transmitida por vetores (mosquitos) $e$ não por contágio. (MASCARENHAS, 2006)
} 
O crescimento da cidade e da população gerou declínio na conservação dos recursos naturais, em especial aos recursos hídricos, dando-se preferência às necessidades industriais, excluindo-se valores importantes quando colocados em escala global como saúde e bem-estar. A geração de energia elétrica a partir da água, fez com que no século passado fosse adotada uma predominância nos estudos desse gênero, não havendo muita relevância nas consequências ambientais. Este fato foi gerado tendo como foco central forças econômicas e políticas (YASSUDA, 1993).

Desta forma, a descentralização do poder quando se trata de recursos hídricos ficou mais evidente e necessária, assim como a necessidade de fixar políticas públicas e leis que tivessem caráter conservacionista com relação aos recursos naturais. No Brasil, tais instrumentos legais só começam a ser postos em prática a partir da promulgação da Constituição de 1988.

O Estado de São Paulo foi um dos pioneiros na construção de sua própria legislação ambiental à respeito dos corpos d'água, criando a Política Estadual de Recursos Hídricos em 1991.

Mesmo tendo os recursos legais como: legislação vigente, Comitês de Bacias Hidrográficas e gestão descentralizada, há muito o que se melhorar na prática, sendo ainda muito expressivo os empasses pelos quais os gestores de deparam frente a complexidade das cidades, como ocorre na Região Metropolitana de São Paulo, visto a quantidade de habitantes, a falta de planejamento de uso e ocupação do solo e as diferenças culturais dos indivíduos em relação as suas opiniões sobre os corpos hídricos.

Nota-se ainda que o entorno destes córregos, em geral é ocupado por moradias de baixa renda, muitas vezes irregulares que descartam dejetos e resíduos sólidos nessas águas, aumentando a probabilidade de transmissão de doenças aos moradores, na eventualidade de ocorrência de enchentes, além de riscos de deslizamento.

Para JACOBI et al. (2015a, p. 40) "além da contaminação dos cursos d'água, por décadas predominaram na cidade de São Paulo políticas públicas que confinaram os rios e córregos em canais retilíneos, canalizando-os para abrir grandes avenidas ao longo dos mesmos"*.

As questões levantadas no presente trabalho visam analisar o problema da poluição dos corpos hídricos, levando-se em consideração a problemática de saúde pública que poderia ser amenizada com a despoluição destes rios esquecidos no emaranhado da grande cidade e com a conscientização da população a respeito das medidas preventivas que devem ser tomadas para evitar as doenças de veiculação hídrica.

\footnotetext{
" [Más allá de la contaminación de los cursos de agua, em la ciudad de São Paulo por décadas predominaron políticas públicas que confinaron a los ríos y arroyos em canales rectilíneos, enterrándolos para abrir grandes ejes viales a lo largo de ellos]
} 
O levantamento do que tem sido discutido pelo Comitê de Bacia Hidrográfica do Alto Tietê e as tomadas de decisão dos gestores, bem como o que tem sido implantado na prática são os pontos que serão discutidos neste trabalho. Concomitantemente, o estudo em questão propõe uma análise crítica a respeito destes corpos d'água em relação a sua gestão e a visão que os gestores possuem dos mesmos.

\section{Problematização da pesquisa}

Na visão de cidade saudável e sustentável que se tem na atualidade, os rios e córregos urbanos não se limitam apenas as variáveis de utilização, drenagem e qualidade, mas passam a ter valor social de apreciação e lazer. Desta forma, além das doenças de veiculação hídrica e as enchentes, a má utilização e gestão destes corpos hídricos impossibilitam que a cidade se torne mais agradável na percepção dos cidadãos que nela habitam. A degradação dos corpos hídricos e o crescimento desordenado das cidades causam situações de risco e segmentação social, desfavorecendo as classes baixas da sociedade. Todos esses fatores distanciam os cidadãos do ambiente natural, acarretando em uma sociedade com pouco ou nenhum vínculo com a natureza.

\section{Objetivos e Produto}

Pretende-se analisar como os corpos hídricos que não possuem relevância para o abastecimento e estão localizados na Bacia Hidrográfica do Alto Tietê (BH-AT) são tratados pela legislação, pelo Comitê da Bacia Hidrográfica do Alto Tietê (CBH-AT) e a efetivação de projetos aprovados pelo Fundo Estadual de Recursos Hídricos (FEHIDRO) que possuem vínculo com a melhoria ou a preservação da qualidade dos rios e córregos.

Para que o objetivo seja alcançado, haverá a compilação das tomadas de decisão realizadas pelos órgãos gestores com a finalidade de encontrar as atividades que priorizem a despoluição e/ou conservação dos corpos d'água, visando a sua melhoria e minimização dos problemas que envolvem os mesmos na RMSP.

O trabalho em questão tem como produto a análise final e o detalhamento da tratativa dos corpos hídricos dentro do CBH-AT e dos projetos financiados, obtendo resultados que podem ser utilizados pelos órgãos responsáveis, a fim de viabilizar não apenas a conservação de rios para abastecimento, mas também a recuperação daqueles que são vias de doenças de veiculação hídrica e que poderiam ser utilizados para outras atividades como recreação, por exemplo. 
Desenvolveu-se um estudo de caso qualitativo de carácter exploratório a partir da pesquisa em atas e deliberações do Comitê de Bacia Hidrográfica Alto Tietê, levantamento de projetos que foram executados através de recursos financeiros do Fundo Estadual de Recursos Hídricos e dos projetos considerados de maior visibilidade e abrangência desenvolvidos com o objetivo de despoluir rios e córregos na RMSP.

\section{Organização da dissertação}

O Capítulo 1 apresenta a revisão bibliográfica, dividida em três tópicos: o crescimento urbano do município de São Paulo e da Região Metropolitana, havendo maior ênfase nas questões do crescimento envolvendo os rios e córregos da cidades; água e saúde pública, permeando questões de doenças de veiculação hídrica e o termo cidades saudáveis; e por fim, uma revisão da legislação e governança da água no âmbito nacional e estadual, detalhando as leis e formas de gestão dos recursos hídricos.

A abordagem metodológica e as características do objeto de estudo encontram-se no Capítulo 2, dedicado a apresentação dos métodos adotados e escolhidos, o recorte feito no projeto, assim como a caracterização da Bacia Hidrográfica do Alto Tietê.

Por fim, encontram-se os resultados e discussão no Capítulo 3, seguido da conclusão no Capítulo 4. Todos os assuntos relevantes para a pesquisa discutidos pelo Comitê em suas reuniões, as deliberações e os projetos aprovados para recebimento de recursos do FEHIDRO encontram-se nos anexos. 


\section{CAPÍTULO 1 - REVISÃO BIBLIOGRÁFICA}

Com o intuito de analisar os corpos hídricos da RMSP e do município com foco na sua preservação e recuperação, buscou-se nortear o trabalho a partir da evolução de temas que unem gestão pública, governança da água, saúde pública e meio ambiente. Desta forma, a revisão a seguir é composta pelos temas: crescimento urbano e rios, abordando a estrutura de crescimento da cidade de São Paulo e da RMSP a partir da perspectiva dos rios e de suas modificações em prol da urbanização; água e saúde pública, fazendo uma revisão sobre os perigos das doenças de veiculação hídrica e discutindo o termo cidades saudáveis; e legislação e gestão da água, pontuando a legislação aplicável no âmbito federal e estadual e trazendo uma breve discussão à respeito da gestão dos recursos hídricos.

\subsection{CRESCIMENTO URBANO DO MUNICÍPIO E DA REGIÃO METROPOLITANA DE SÃO PAULO E SEUS RIOS}

A RMSP possui uma grande rede hídrica, a qual faz parte da história do município de São Paulo desde o início da construção da vila, antes mesmo de tornar-se uma cidade. Para entender esta dinâmica entre o crescimento da cidade e os rios que nela habitam, há a necessidade de levar em consideração o seu crescimento, juntamente com as alterações na paisagem causadas.

\subsubsection{SURGIMENTO DO MUNICÍPIO DE SÃO PAULO}

O povoamento da região que hoje é a cidade de São Paulo, fundada em 1554, iniciou-se a partir de sua posição favorável próxima ao rio Tietê e seus afluentes, os quais eram utilizados como fonte de comunicação, além de possuírem várzeas férteis para plantio e abundância de água para diversos usos na época (FARIA, 2004). MASSARA (2012, p. 234) pontua que "a escolha do local para fixação do colégio indigenista - o promontório, na proximidade da ligação entre os rios Anhangabaú e Tamanduateí - definiu o marco de expansão urbana da cidade", a qual não havia se desenvolvido muito até o século XVIII.

Os rios que faziam parte da dinâmica da vila eram aqueles que direcionavam a capitania para o interior e transformaram-se na via de comunicação e transporte, tendo suas margens como pontos de parada, descanso e assentamento, abrindo caminho até a Serra do Mar (SANTOS, 2011). A cidade de São Paulo desde sua construção possuía uma relação direta com os rios, como disserta SPOSATI (2001, p. 80): 
(...) Sua vida sempre dependeu da relação de transposição das várzeas e da travessia dos cursos d'água, através da união de vales por viadutos e pontes (...).

O Tamanduateí, hoje em grande parte canalizado e margeado pela famosa Avenida do Estado, que liga São Paulo ao ABC, exerceu papel central na São Paulo colonial.

Foi a partir do século XIX que houve maiores modificações e reais alterações na configuração da cidade, expandindo-se desde então. AZEVEDO (1958, p. 12) disserta sobre alguns fatores que explicam o acelerado crescimento da cidade a partir das décadas de 1870 a 1880, estando entre eles a "expansão da cultura cafeeira"; o aumento de vias férreas, que percorria São Paulo para o porto de Santos; a vinda de imigrantes e de cidadãos de outros municípios e estados; e a entrada de capital estrangeiro para construção de hidrelétricas, linhas de bonde, construção de casas e indústrias.

A população que residia no município de São Paulo nos primeiros anos do século XIX tinha constante contato com rios e bicas, pois não havia qualquer tipo de saneamento na região, exigindo de seus moradores o deslocamento e coleta da água para consumo (ASSUNÇÃO, 2009).

A estrutura que se formava na cidade foi definida entre os anos de 1901-1920, delimitando nas partes altas da cidade os bairros mais nobres e nas partes baixas os bairros populares, operários e pobres, locais muitas vezes próximos as várzeas, onde haviam animais peçonhentos e com isso menor valor de mercado devido à insalubridade e aos perigos oferecidos. Eram formados núcleos dispersos mais afastados da região central, devido aos altos custos dos terrenos inflacionados do centro, vindo aqueles núcleos a se transformarem nos bairros. Este modelo de expansão se sustentou ao longo dos anos como é possível observar até os anos 1940, sendo que a classe operária se mantinha em maior número na região do Brás e Bom Retiro, formando os antigos cortiços que passariam a ser chamados de vilas que se alocavam próximas às indústrias (PEREIRA e PIRES, 2008; ASSUNÇÃO, 2009; GUZZO, 2014).

\subsubsection{PRIMEIRAS INTERVENÇÕES NOS RIOS}

Não é necessário muito esforço para observar a ligação do crescimento da cidade com a degradação e modificação estrutural de seus rios que foram canalizados e cobertos.

A primeira intervenção em um rio da cidade ocorreu no ano de 1848 , no rio Tamanduateí, porém a discussão sobre esta intervenção vinha sendo construída desde meados dos anos 1821 pela Comissão de Saneamento de São Paulo, não podendo ela ser efetuada na época devido à falta de recursos financeiros, voltando a ser analisada apenas 20 anos depois pelo engenheiro Carlos Abraão Bresser (ASSUNÇÃO, 2009; SANTOS, 2011). 
O rio Tamanduateí possuía sete curvas chamadas "sete voltas", as quais foram extintas pela abertura de um canal reto paralelo ao rio e com maior profundidade em relação a ele. Esta intervenção foi realizada na esperança de diminuir as enchentes que ocorriam no local, onde atualmente se encontra a Rua 25 de Março (SANTOS, 2011, p. 44). Com o passar do tempo, observou-se cada vez mais o aumento das enchentes e a disseminação de doenças de veiculação hídrica, com o acúmulo dos dejetos urbanos e a diminuição da autodepuração do rio.

A segunda intervenção ocorrida no rio Tamanduateí incidiu entre os anos 1896 e 1914, quando um trecho próximo ao centro da cidade foi retificado. Esta retificação foi feita para extinguir as águas estagnadas com dejetos e resolver o problema com enchentes (SANTOS, 2011).

No ano de 1903, o fiscal de rios José Joaquim de Freitas já fornecia dados à respeito da diminuição da qualidade das águas do rio Tietê devido aos despejos de esgoto "in natura" em suas margens (SANTOS, 2011). SANT'ANNA (2004, p. 89) pontua o que ocorria na cidade no final do século XIX, confirmando a situação de degradação crescente dos rios urbanos de São Paulo:

Alguns rios que ainda não haviam ganho o subterrâneo da cidade e, portanto, desaparecido da visão de seus moradores, tendiam a ser transformados em esgotos a céu aberto. (...) o antigo deleite de dispor de uma paisagem aquática no espaço público era pouco a pouco esquecido.

\subsubsection{RETIFICAÇÃO DOS RIOS E CONSTRUÇÃO EM FUNDO DE VALE}

Francisco Rodrigues Saturnino de Brito havia proposto a instalação de comportas, lagos e margem para manutenção em projeto proposto para o Rio Tietê em 1924, porém, em 1927 houve a modificação do projeto, feita por João Florence de Ulhoa Cintra, determinando que a ocupação das margens seria por avenidas e pontes. Com isso, não só no rio Tietê, mas também no Tamanduateí e Pinheiros, foram feitas retificações nos trajetos dos rios e abertura de canais para que a água corresse com maior velocidade, evitando a estagnação dos resíduos jogados, além da operação do sistema hidrelétrico da empresa Light, que iria amenizar a incidência de enchentes, o que não ocorreu (JORGE, 2011; OLIVEIRA, 2014).

Prestes Maia propôs o Plano de Avenidas em 1930 o qual possuía uma concepção urbanística que incentivava a construção de avenidas nos fundos de vale pelo relevo acidentado que a região apresentava. Para MAIA (2010) a canalização dos rios Tietê e Tamanduateí foi vista como um grande melhoramento suburbano por obter $40 \mathrm{~km}^{2}$ de solo fora do alcance dos rios, os quais poderiam entrar no mercado para venda do terreno e serem utilizados para a construção das avenidas. A canalização do trecho do rio Tietê que passa pela 
cidade de Osasco reduziu para $1,5 \mathrm{~km}$ o trajeto que era originalmente de $6 \mathrm{~km}$ com os seus meandros.

A canalização dos rios e córregos tinha como função principal aumentar a velocidade de escoamento e com isso impedir a parada dos esgotos e a incidência de enchentes. Porém, com a eliminação dos meandros, ocorre menor autodepuração, demorando mais tempo para a matéria orgânica se decompor. Como explicam TRAVASSOS e GROSTEIN (2013), os rios Tietê e Pinheiros estão localizados em baixa declividade, diferente dos seus afluentes, o que contribui para a incidência de enchentes e à medida que mais afluentes são canalizados, mais agrava a situação, pois a água chega com maior rapidez nos rios Tietê e Pinheiros, fazendo com que os mesmos tenham que comportar maiores quantidades de água durante as chuvas.

Diferentemente de Maia, citado anteriormente, para CUSTÓDIO (2004, p. 92) o Plano de Avenidas assumia uma "postura menos técnica, elitista e personalista, menos submetida aos interesses fundiários", sendo apontado que um "ideário modernizador" teria pensado na população e nas inundações, adicionando as matas ciliares às margens, como sugerido no projeto de Saturnino de Brito.

TRAVASSOS e GROSTEIN (2013) colocam como ponto relevante o favorecimento dos automóveis particulares sobre o transporte público que na época era baseado nos sistemas de trilhos, ferrovias e bondes. O Plano de Avenidas exaltou a expansão da rede viária com o incentivo aos serviços de ônibus, os quais permitiam maior flexibilidade que bondes e trens, contribuindo para o alargamento das periferias, havendo uma expansão horizontal, evitando a desvalorização dos centros, ao mesmo tempo em que reduzia ou anulava o gasto com pagamento de aluguel e facilitava a circulação de mercadorias e trabalhadores (ROLNIK et al., 1990; ROLNIK, 2003; TRAVASSOS, 2015).

Mais adiante, entre os anos de 1938 e 1945, o prefeito de São Paulo, Prestes Maia, intensificou a construção de avenidas de fundo de vale, construções que eram favorecidas pela concepção de que os corpos hídricos "eram vistos como agentes de poluição e destruição" (FELÍCIO e SILVA, 2009, p. 13; TRAVASSOS, 2015), o que resultou em drásticas alterações nos rios e córregos da cidade (ROLNIK et al., 1990, p. 76):

No caso de córregos e rios menores, ganhou-se espaço diretamente sobre seus leitos, canalizados em galerias fechadas, sobre as quais foram construídas as vias de circulação; no caso do Tietê, Pinheiros e Tamanduateí, tratou-se do aprofundamento dos canais, através da definição de seções que garantissem o escoamento das vazões máximas previstas e construíram-se avenidas marginais junto ao limite dos canais, liberando-se as várzeas para a urbanização.

Em estudo FELÍCIO e SILVA (2009, p. 6-7) identificaram três tipos de uso predominantes em fundos de vale sendo eles: a "urbanização intensiva" que são os entornos 
dos corpos d'água densamente ocupados, caracterizando ambientes extremamente impermeabilizados e com pouca ou nenhuma mata ciliar; as "condições seminaturais" em que o entorno dos corpos d'água são parcialmente ocupados e possuem regiões verdes e de retenção de água; e "condições naturais ou reflorestamento" que é o menos encontrado nas regiões metropolitanas por serem áreas identificadas com abundância de mata ciliar ou reflorestada, o que não faz parte da realidade na maioria das cidades urbanizadas.

\subsubsection{CRESCIMENTO URBANO E INDUSTRIAL}

O crescimento urbano foi marcante no Estado de São Paulo, principalmente no século XIX. De acordo com PASTERNAK e LEME (2010), estima-se que entre os anos 1888 e 1900, passaram quase 264 mil imigrantes pelo Estado. O Estado apresentou um crescimento de $43 \%$ da sua população urbana entre os anos 1920 a 1940 (SANTOS, 1993). TOLEDO (2004, p. 78) cita que a "epidemia de urbanização" foi fomentada pela vinda do transporte público, a instalação da primeira linha de bonde da capital paulista no final do século XIX.

O município de São Paulo destacou-se a partir dos anos 1920 (quando a cidade contava com aproximadamente 579 mil habitantes) devido à colonização por imigrantes europeus, ao rápido crescimento do potencial energético, à grande oferta de matéria-prima e à localização da cidade, tornando-a ponto de conexão entre as regiões produtoras de café e o porto, que consequentemente tornaram o Estado o mais importante centro industrial do país (SUZIGAN, 1971; ROLNIK, 2003; JORGE, 2011). Esta industrialização foi auxiliada pela regularização do trabalho urbano, a existência da Estrada de Ferro que facilitava o transporte para as indústrias e a construção das marginais Pinheiros e Tietê, resultando em maior infraestrutura industrial (MARICATO, 2003; MASSARA, 2012).

Em 1958, o parque industrial da cidade já era considerado o mais poderoso da América do Sul (AZEVEDO, 1958). Consequentemente, a cidade de São Paulo passou por seu primeiro surto industrial, prevalecendo indústrias têxteis e alimentícias, as quais ocupavam as várzeas próximas às ferrovias, junto com a população de baixa renda. Nesta fase, a dinâmica do uso dos recursos hídricos focava em produção de energia elétrica, que era controlada pela companhia Light (ROLNIK, 2003, p. 29):

Durante toda a década de 20, o investimento prioritário da Light foi a obtenção da concessão do rio Pinheiros, afluente do Tietê, para reverter seu curso e alimentar uma represa artificial - a Billings - no alto da serra. Controlando o fluxo do Tietê por meio das estações elevatórias de Traição e Pedreira, a Light obteria a água necessária para alimentar o curso invertido do rio Pinheiros, mantendo seus reservatórios do sistema hidrelétrico em nível máximo. 
Neste momento, a empresa Light já havia construído a usina hidrelétrica de Parnaíba, instalada no rio Tietê próximo a Santana de Parnaíba e comprado a usina hidrelétrica Lavras, construída pela Companhia Ituana Força e Luz, a qual também utilizava as águas do rio Tietê na cidade de Salto. Além disso, havia construído a represa Guarapiranga, com o objetivo de aumentar a vazão do rio Tietê para elevar a capacidade de geração de energia elétrica na usina de Parnaíba (SANTOS, 2011).

Com a crescente demanda de mão de obra, seria muito difícil que se impedisse a expansão de moradias nas margens dos rios e das várzeas, trazendo preocupação para a administração pública já naquela época devido às enchentes e ao depósito de resíduos. Houve, durante a década de 1920, o incremento da expansão das Vilas na capital, as quais ocupavam as várzeas dos rios, como, por exemplo, a Vila Maria Baixa se estabelecendo às margens do rio Tietê e a Vila Independência e Vila Carioca na várzea do rio Tamanduateí. Não obstante, residências da população com maior poder aquisitivo também se consolidavam, como a Cidade Jardim às margens do rio Pinheiros (ROLNIK, 2003; TRAVASSOS, 2015).

As obras de saneamento nesta época eram destinadas ao afastamento do esgoto das áreas mais nobres, sendo este descartado nos rios, comprometendo as águas dos rios Tamanduateí e Tietê, fazendo com que a população de baixa renda que residia nessas localidades fosse obrigada a conviver com os despejos da cidade. Os rios que antes eram utilizados por lavadeiras, pescadores, barqueiros e para prática de esportes aquáticos, estavam sendo abandonados, tornando-se um local indesejado dentro da dinâmica da cidade. Além do precário sistema de saneamento, até a década de 1970, utilizava-se lixo como material de aterro das várzeas, contribuindo para a poluição das várzeas e dos rios (ROLNIK et al., 1990; SANTOS, 2011).

Francisco Rodrigues Saturnino de Brito, citado por JORGE (2011), já apontava em 1926 a preocupação com a integridade dos rios e os problemas de saúde pública ocorridos, levantando a problemática sobre a insistência do homem em instalar-se próximo aos rios e a concretização do crescimento da mancha urbana nessas localidades (TRAVASSOS, 2015, p. $1)$ :

\footnotetext{
Ali, os rios Tietê e o Tamanduateí eram meândricos, de baixa declividade, contando com curvas extensas e leitos abandonados, além de áreas inundadas que se destacavam dos corpos principais. Suas várzeas eram extensas e encharcadiças, suas águas corriam vagarosamente.
}

Com o crescimento demográfico e a construção de sistemas de abastecimento de água, rede de esgoto e luz, a especulação imobiliária com altos preços de mercado tomou conta do centro, resultando na expansão da mancha metropolitana, devido a necessidade da população de baixa renda ir em busca de locais mais baratos para morar. Este modelo de 
ampliação da metrópole ainda é muito vivo na capital paulista, tendo as moradias mais precárias nas zonas periféricas da cidade, além de obrigar a população de baixa renda a ir para áreas rejeitadas pelo setor imobiliário como várzeas, beira de córregos, encostas de morros, áreas poluídas, contaminadas e até mesmo de preservação permanente (ROLNIK et al., 1990; MARICATO, 2003; JORGE, 2011).

SANTOS (1993) discute o modelo centro-periferia sobre a expansão das metrópoles, sendo possível observar que havendo especulação, acentua-se as dificuldades de acesso à terra e habitação. $\mathrm{O}$ déficit de residências e a especulação conduzem a população de baixa renda às periferias da cidade. Em contrapartida, os centros urbanos tornam-se cada vez mais atrativos devido ao fácil acesso e funcionalidade, criando-se assim, pontos mais valorizados. Desta forma, o marketing feito pelo mercado imobiliário, tende a gerar expectativas de serviços coletivos diferenciados, tornando áreas inabitadas em atrativas e expandindo a metrópole.

Há ainda a concepção de crescimento da cidade a partir do "movimento de segregação" de classes, difundido pelo trabalho assalariado. Esta segregação deu-se pela quantidade de renda versus preço da moradia, de acordo com a quantia que cada cidadão podia (ou pode) dispor para pagar sua residência. Pode-se observar esta dinâmica no trecho a seguir extraído de ROLNIK (1994, p. 48):

Em São Paulo, por exemplo, esta é a história dos Campos Elísios, Higienópolis e depois a Avenida Paulista, obras da burguesia paulistana enriquecida com o capital gerado pelo trabalho nos cafezais. Esta é também a história do Brás, da Barra Funda, da Lapa, bairros de mulatos e imigrantes, trabalhadores assalariados da cidade.

Para JANNUZZI (2004, p. 30) a redistribuição da população no espaço urbano passou a ter verticalização crescente, "compactando" os espaços ocupados no sentido do centro para as periferias, seguindo o curso das ferrovias e das vias rodoviárias. Desta forma, se observa a expansão das periferias e a diminuição do crescimento nas áreas centrais.

Esta alteração resultou no esvaziamento dos centros, sendo estes empresariais, configuração que vem sendo trabalhada pelo mercado imobiliário com a construção de apartamentos residenciais compactos no centro do município. MEYER et al. (2015) dissertam que a dispersão dos loteamentos residenciais gerou os "municípios dormitórios", os quais não possuem infraestrutura e empregos suficientes para conter esta população em sua região residencial. CARLOS (2003, p. 82) faz uma reflexão sobre o tema interpretando da seguinte forma: 
imensas periferias e o esvaziamento do centro. No caso de São Paulo, isto significa que o constante movimento da reprodução da metrópole faz implodir o centro, produzindo novas centralidades (...). Ao mesmo tempo se dispõem em torno da metrópole aglomerações secundárias, cidades satélites. As periferias se estendem a perder de vista (...).

Apesar do crescimento contínuo do município e da RMSP, é evidenciado que entre os anos 1980 a 2000 houve taxas inferiores de crescimento populacional em comparação com as taxas nacional e estadual, como aponta BAENINGER (2005). A autora ainda discorre que apesar deste fato, a taxa de crescimento das moradias irregulares de população de baixa renda na metrópole foi maior que a média do Estado, evidenciando, em parte, as desigualdades, as consequências da alta especulação imobiliária, a crise e recessão econômica ocorridas nas décadas de 1980 e 1990. (Tabela 1).

Tabela 1 - População Total e Taxas de Crescimento Populacional - Estado de São Paulo, Região Metropolitana de São Paulo e Município de São Paulo - 1970 a 2000.

\begin{tabular}{|c|c|c|c|c|c|c|c|c|}
\hline \multirow{2}{*}{ Área } & \multicolumn{5}{|c|}{ População Total } & \multicolumn{3}{|c|}{$\begin{array}{c}\text { Taxa Média de } \\
\text { Crescimento (\% a. a.) }\end{array}$} \\
\hline & 1970 & 1980 & 1991 & 1996 & 2000 & $\begin{array}{c}1970- \\
1980 \\
\end{array}$ & $\begin{array}{c}1980- \\
1991 \\
\end{array}$ & $\begin{array}{c}1991- \\
2000 \\
\end{array}$ \\
\hline $\begin{array}{l}\text { Estado de } \\
\text { São Paulo }\end{array}$ & 17.771.948 & 25.040 .712 & 31.436 .273 & 34.404.358 & 37.035.456 & 3,49 & 2,13 & 1,78 \\
\hline RMSP & 8.139 .730 & 12.588 .725 & 15.416 .416 & 16.581 .933 & 17.833 .511 & 4,46 & 1,86 & 1,63 \\
\hline Capital & 5.924 .615 & 8.493 .226 & 9.626 .894 & 9.839 .066 & 10.435 .546 & 3,67 & 1,15 & 0,87 \\
\hline Periferia* & 2.215 .115 & 4.095 .499 & 5.789 .522 & 6.742 .867 & 7.397 .965 & 6,34 & 3,20 & 2,81 \\
\hline
\end{tabular}

Fonte: BAENINGER (2005, p. 89).

* Moradias irregulares de população de baixa renda

Segundo MARICATO et al. (2010, p. 51), na cidade de São Paulo ocorre a "migração interna", tendo diminuição do crescimento nos centros e maior exploração das periferias da cidade, afetando "áreas ambientalmente vulneráveis". Esta diminuição no crescimento leva a possível tendência de estabilidade demográfica, porém esta estabilidade não está ligada as melhores condições de habitação. Segundos os autores, estudos mostram que apesar da verticalização, os locais onde houve intensa atividade imobiliária passaram a ter menores taxas de crescimento demográfico. 


\subsubsection{A REGIÃO METROPOLITANA DE SÃO PAULO}

O crescimento demográfico da região, como já citado anteriormente, foi se modificando, desconcentrando grande parte da população que residia no município de São Paulo para as demais cidades da região metropolitana. Segundo CLEMENTINO e ALMEIDA (2015, p. 212) pode-se denominar metrópoles como "áreas urbanas que, por força da necessidade de sistematização do planejamento das cidades, são definidas como espaços especiais pelas funções que exercem, pelo tamanho de sua população, pela inexistência de limites perceptíveis entre os municípios".

O agrupamento metropolitano foi reconhecido a partir da Lei Complementar $n^{\circ} 14 / 73$, a qual estabelece as cidades que fazem parte da RMSP sendo elas: São Paulo, Arujá, Barueri, Biritiba-Mirim, Caieiras, Cajamar, Carapicuíba, Cotia, Diadema, Embu, Embu-Guaçu, Ferraz de Vasconcelos, Francisco Morato, Franco da Rocha, Guararema, Guarulhos, Itapecerica da Serra, Itapevi, Itaquaquecetuba, Jandira, Juquitiba, Mairiporã, Mauá, Mogi das Cruzes, Osasco, Pirapora do Bom Jesus, Poá, Ribeirão Pires, Rio Grande da Serra, Salesópolis, Santa Isabel, Santana de Parnaíba, Santo André, São Bernardo do Campo, São Caetano do Sul, Suzano e Taboão da Serra. Desta forma, foi reconhecido como interesse metropolitano, entre outros, o aproveitamento dos recursos hídricos e o controle da poluição ambiental (art. 5).

VERAS (2001) disserta que esta nova configuração urbana foi composta não só pela pressão do mercado imobiliário perante as moradias, mas também pelo deslocamento das indústrias para as regiões mais periféricas. A autora defende que o aumento da atividade industrial foi propulsor para o desenvolvimento econômico e urbano da região. Segundo MONTALI (1991, p. 386) o desenvolvimento da RMSP deu-se a partir da industrialização que ultrapassou os limites territoriais do município de São Paulo, instalando indústrias nas cidades vizinhas, como ocorreu a partir dos anos 1950, quando houve a vinda de "novos ramos de bens de produção", que consequentemente proporcionou a expansão das cidades com a instalação de áreas comerciais e moradias devido ao aumento dos empregos nessas regiões. Afirma ainda que as novas indústrias dos ramos de "material de transporte e elétrico, química, borracha, metalúrgica e automobilística" alocaram-se nas cidades localizadas no limite no município e nas regiões periféricas da cidade de São Paulo devido à supervalorização dos terrenos localizados nos centros industriais, os quais foram propulsores para o crescimento da cidade de São Paulo e onde moravam os operários.

Sobre os recursos hídricos JACOBI (2006, p. 117) pontua que: "a partir dos anos 1950 (...) ocorrem dois movimentos simultâneos: a intensificação das intervenções na rede de drenagem, com obras de retificação e canalização dos rios, o aterramento das várzeas e sua incorporação à malha urbana", além da degradação dos recursos hídricos e do solo que como consequência afetam a saúde da população, resultando em problemas socioambientais.

MEYER et al. (2015) apontam a indústria automotiva como o primeiro setor produtivo moderno, localizado nos "municípios operários do ABC paulista, Santo André, São Caetano e São Bernardo". Este movimento transitório de indústrias é consequência do alto custo da capital paulistana, resultando na dispersão da população, como mostram os Gráficos 1 e 2 . 
Considera-se o pico da industrialização da RMSP o ano de 1970, concentrando $42 \%$ da produção industrial do país, ocorrendo a sua queda gradativa e diminuindo quase $10 \%$ até 2005, devido à reestruturação industrial (DINIZ e CAMPOLINA, 2007).

Gráfico 1 - População no município de São Paulo e na Região Metropolitana de São Paulo (RMSP) nos anos 1991, 2000, 2010 e 2015.

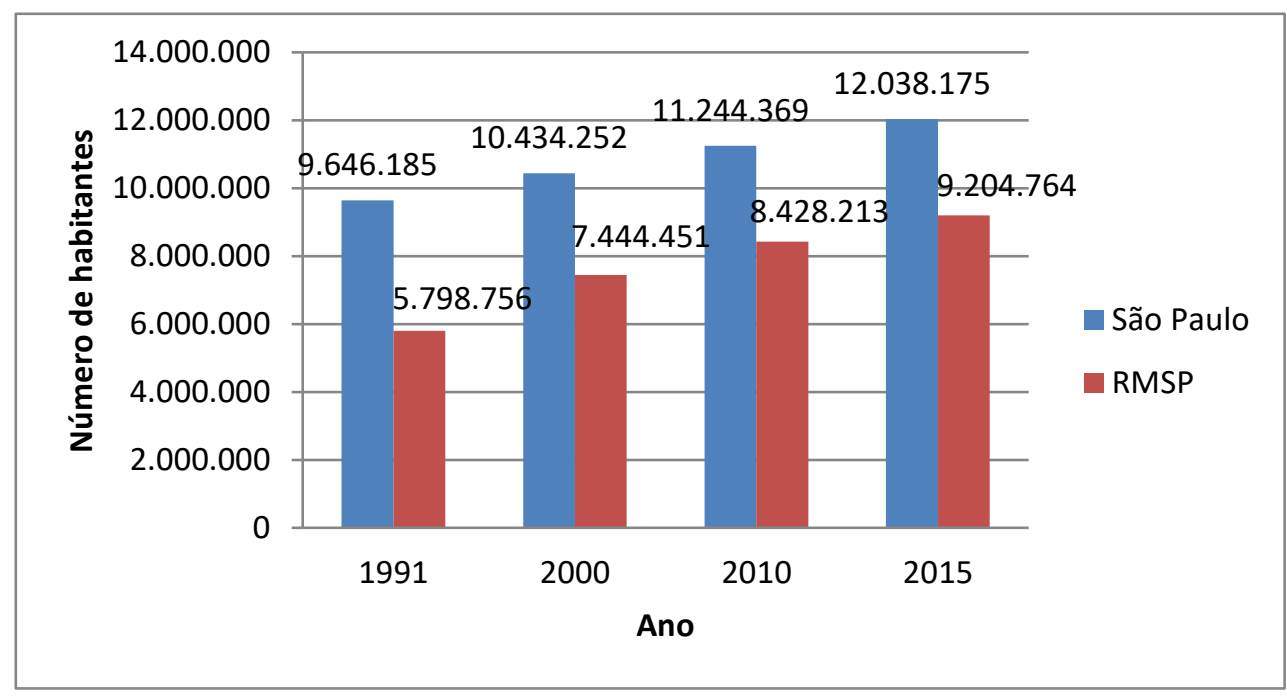

Fonte: Criado pela autora com base em dados do IBGE.

Gráfico 2 - Porcentagem de crescimento demográfico no município de São Paulo e na Região Metropolitana de São Paulo (RMSP) entre os anos de 1991 - 2000, 2000 - 2010 e $2010-2015$.

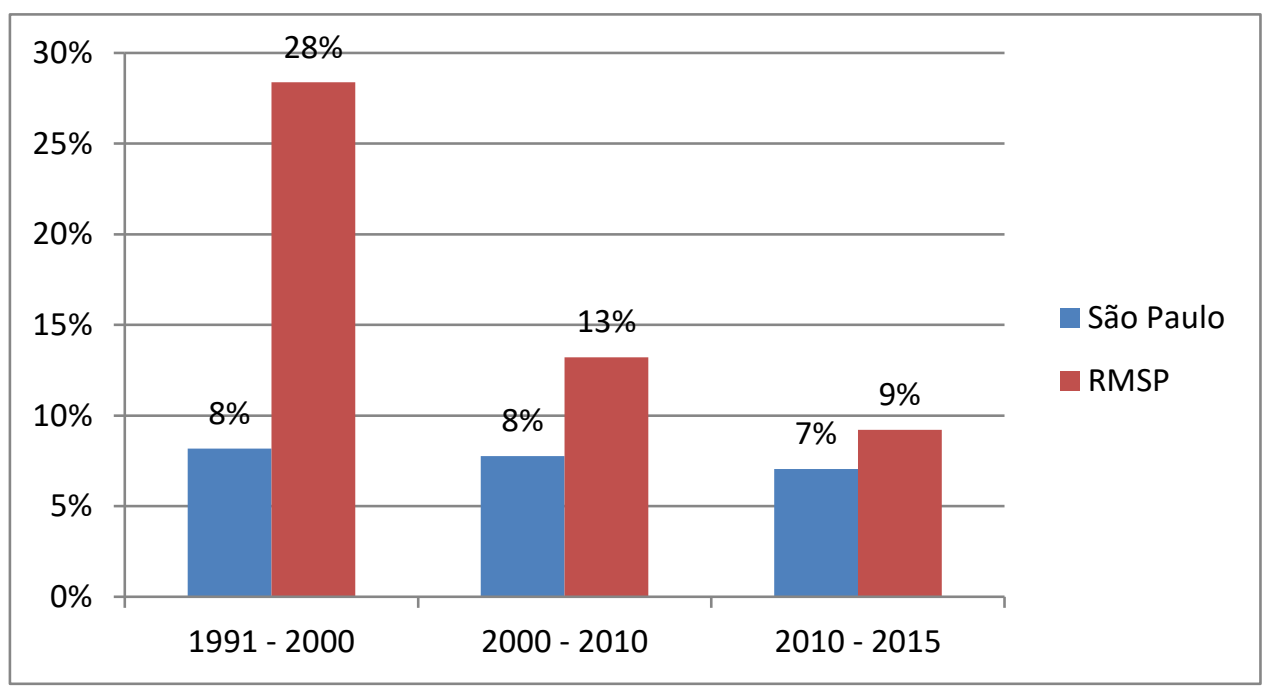

Fonte: Criado pela autora com base em dados do IBGE. 
MARQUES e REQUENA (2013) elaboraram mapas do crescimento demográfico da RMSP entre os anos 1991-2000 e 2000-2010 (Figuras 1 e 2). Nestes mapas é possível visualizar claramente a diminuição do crescimento demográfico em toda a região (comparando-se as duas décadas) e a expansão concentrada nas áreas mais periféricas (sendo esta expansão mais ativa entre os anos 1991 a 2000). Para os autores há diversas questões que explicam a queda do crescimento nas regiões periféricas de uma década para a outra estando entre elas: o crescimento das regiões centrais a partir dos investimentos do setor imobiliário; o esvaziamento de regiões próximas as áreas centrais com alto custo, porém sem atividades imobiliárias, invasões ou migrações recentes; e a inclusão de áreas periféricas crescentes e de menores valores de mercado.

Figura 1 - Crescimento demográfico por área de ponderação da Região Metropolitana de São Paulo, entre os anos 1991 a 2000.

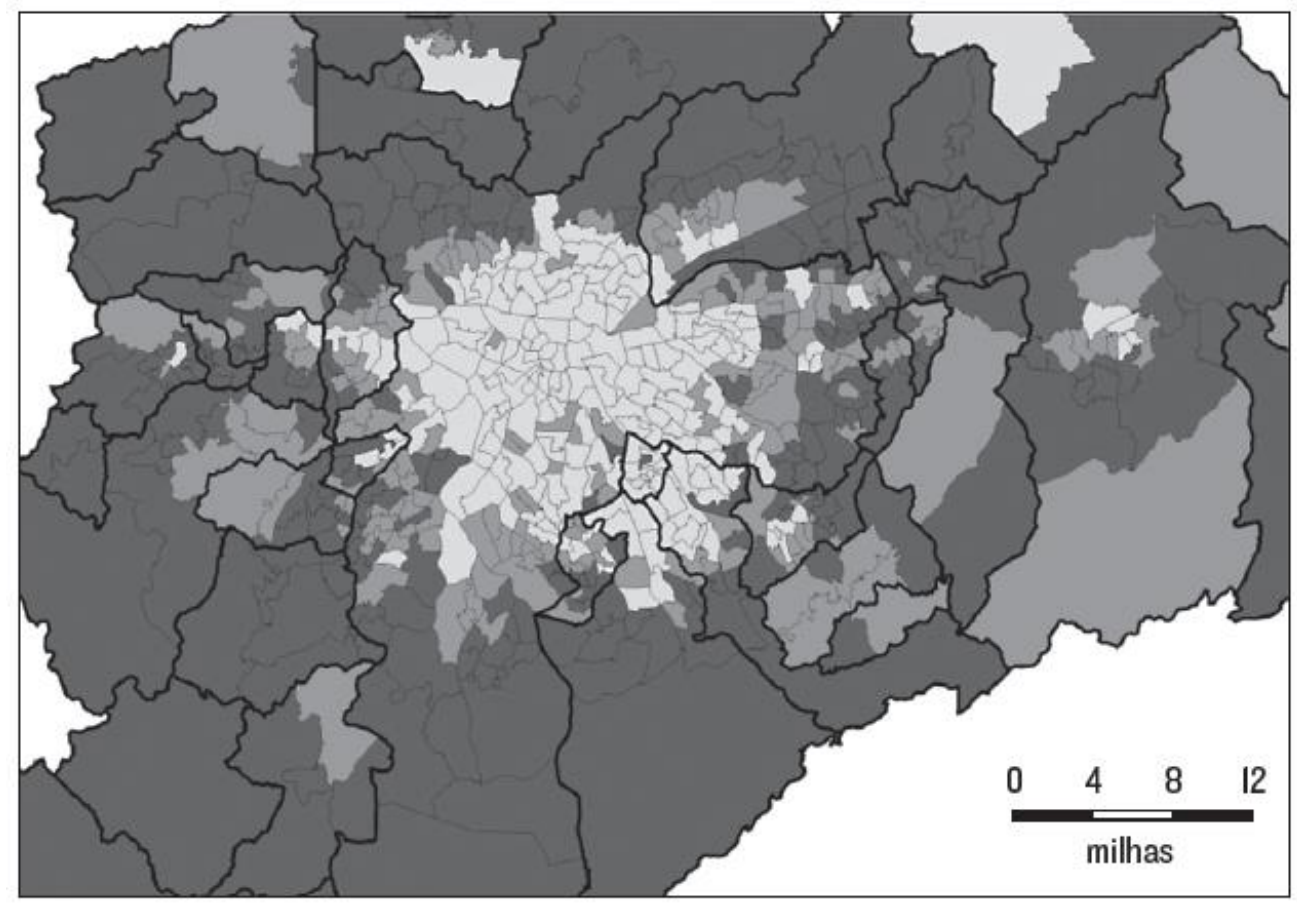

Legenda (\% a a):

-10 a 0

0 a 2,5

2,5 a 35

Fonte: MARQUES e REQUENA, 2013, p. 22. 
Figura 2 - Crescimento demográfico por área de ponderação da Região Metropolitana de São Paulo, entre os anos 2000 a 2010.

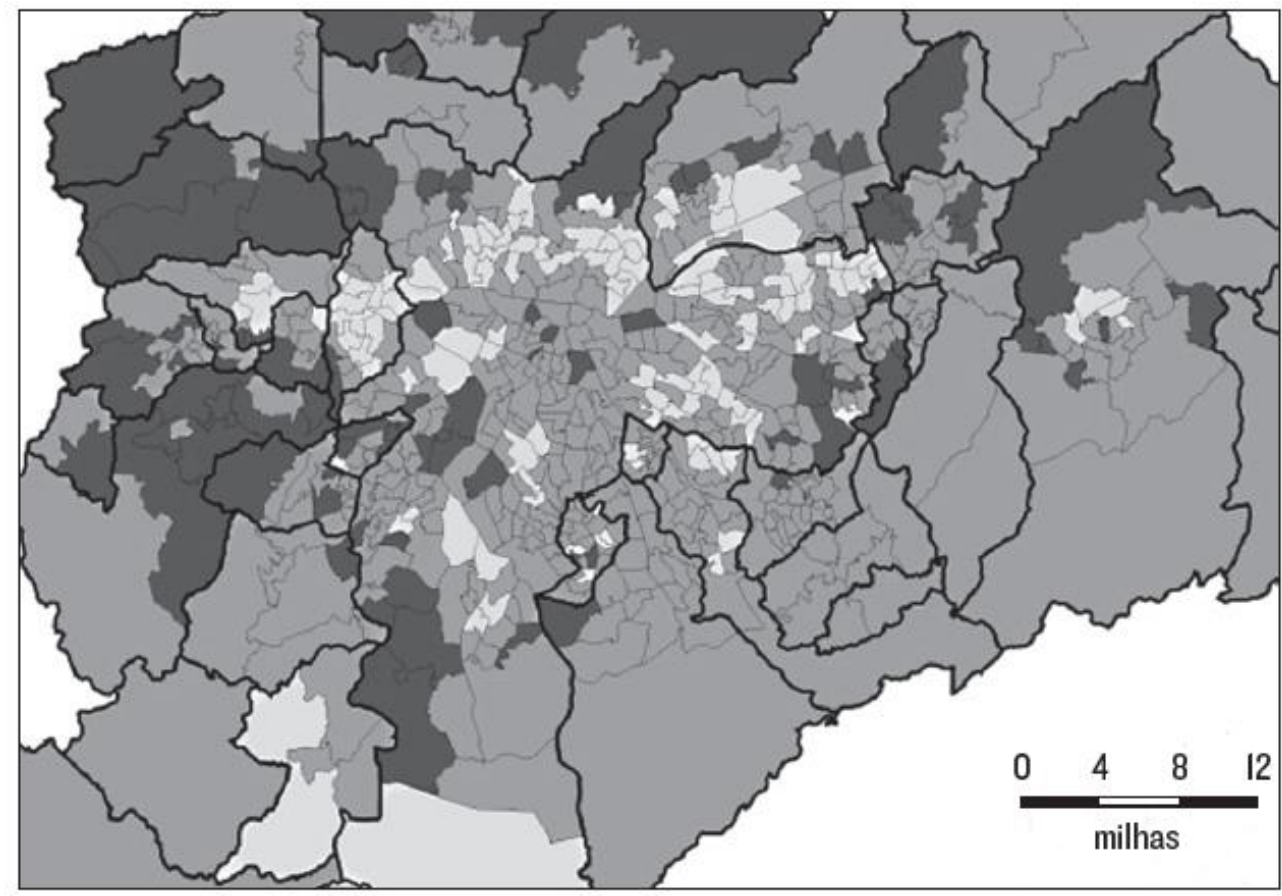

Legenda (\% a a):

-10 a 0

0 a 2,5

2,5 a 10

Fonte: MARQUES e REQUENA, 2013, p. 22.

Segundo FRACALANZA e CAMPOS (2006), a partir da década de 1990 houve mudança no ponto de vista em relação à água na RMSP, passando a ter não só uma visão sanitarista, mas de preocupação com a degradação dos corpos hídricos. Dentro desta visão surgiram projetos de despoluição como o do rio Tietê e o projeto Córrego Limpo. Porém ainda existem incongruências causadas pela falta de articulação entre gestores e sociedade civil quando se trata de realocação ou urbanização de Áreas de Preservação Permanente (APP's).

As áreas verdes estão cada vez mais ameaçadas diante do crescimento horizontal da RMSP, espalhando-se a ponto de passar a ser avaliada e pesquisada na forma macro, adotmmkando-se a nomenclatura de macrometrópole paulista (São Paulo, Campinas, Baixada Santista, Vale do Paraíba, Litoral Norte, Sorocaba, Jundiaí, Piracicaba e Bragantina) tema abordado atualmente por diversos pesquisadores (BONDUKI, 2011; MEYER et al., 2015). Há ainda a dificuldade de implementar mecanismos efetivos que protejam as áreas de proteção ambiental e que consequentemente acabam se tornando áreas de "pressão de ocupação", as quais tornam-se regiões vulneráveis tanto em dimensões ambientais quanto sociais (JACOBI, 2006, p. 120). 


\subsubsection{CONSEQUÊNCIAS DO MODELO DE CRESCIMENTO DO MUNICÍPIO}

ROLNIK et al. (1990) salientam a ineficácia das soluções propostas de canalização e retificação dos rios, visto que surgiram enchentes em proporções catastróficas para a cidade devido ao assoreamento dos canais causado pela terraplanagem, a remoção e impermeabilização do solo, que têm como consequência uma maior velocidade de escoamento da água. Outro quesito que estimula o agravamento das enchentes é a ocupação por avenidas e vias expressas às margens ou acima dos corpos hídricos (BONDUKI, 2011).

Como sequela observou-se logo após o rápido crescimento da cidade, a deterioração causada pela falta de planejamento, resultando na poluição das águas, enchentes, entre outros fatores de saúde, segurança e bem estar. FIORAVANTI (2013) pontua que o rio Tietê, onde era possível nadar, pescar e passear de barco, já era um verdadeiro esgoto a céu aberto nos anos de 1950, quando a população passava dos 1,3 milhão de habitantes. Nesta mesma época, o prefeito resolveu interligar as redes de esgoto da cidade, despejando-o no rio Tietê (OLIVEIRA, 2014).

Nos anos 1960, os rios Tietê e Pinheiros já haviam sido retificados devido a situação catastrófica de poluição encontrada e a construção de grandes avenidas às margens dos rios.

Em 1968 foi criada a Companhia de Tecnologia de Saneamento Básico, a atual Companhia Ambiental do Estado de São Paulo - CETESB - responsável pelo controle, fiscalização, monitoramento e licenciamento de atividades causadoras de poluição das águas, ar e solo, a partir do Decreto $\mathrm{n}^{\circ} 50.079$, mostrando a preocupação que assomava o assunto.

Segundo MARICATO (2003, p. 154), o PLANASA - Plano Nacional de Saneamento Básico, "abandonou os critérios legais de uso e ocupação do solo para estender o fornecimento de água à população até então não atendida em diversas áreas da metrópole" durante o regime militar, permitindo a SABESP - Companhia de Saneamento Básico do Estado de São Paulo, a ampliação das redes de água. O resultado desta iniciativa foi a diminuição da mortalidade infantil. Contudo, entre os anos 1989 e 1992, ocorreu retrocesso, não havendo mais a prestação deste serviço para loteamentos em áreas de proteção dos mananciais.

Já entre os anos 1970 e 1980 observa-se uma crescente expansão nas periferias dos centros urbanos, os quais não possuíam saneamento básico, agravando ainda mais a situação dos corpos d'água da metrópole. Este crescimento horizontal ultrapassou os limites do município, ocupando as demais cidades da região metropolitana, tendo uma proporção cada vez menor do crescimento da cidade de São Paulo em relação às cidades da região, passando de 67\% em 1980 para 58\% em 2000 (MARICATO, 2003; PASTERNAK e LEME, 2010).

O que se vê nas áreas urbanas de proteção ambiental são ocupações inadequadas da população de baixa renda "comprometendo áreas ambientalmente sensíveis, como beiras de córregos, mangues, dunas, várzeas e matas" afetando de forma negativa os recursos hídricos (MARICATO et al., 2010, p. 49). Sobre o tema, BONDUKI (2011, p. 26) disserta que: 
A tolerância ou incapacidade de coibir usos e ocupações irregulares marca o desrespeito às normas urbanísticas e ambientais.

Por falta de política e planejamento habitacional, mais de dois milhões de pessoas habitam irregularmente as regiões de proteção ambiental.

Exemplo desta ocupação é o entorno das Bacias das Represas Billings e Guarapiranga, as quais deveriam estar protegidas pela Lei de Mananciais, mas são ocupadas e ignoradas pelo poder público, devido à alta complexidade do quadro, sendo necessário desalojar milhares de famílias para obter uma área novamente protegida na prática, o que é inviável aos olhos dos representantes públicos (MARICATO, 1994). As autoras PASTERNAK e LEME (2010, p. 42) apontam que:

\footnotetext{
Entre 1970 e 1990, o processo de urbanização destruiu 31\% das áreas recobertas por matas, ocupou fundos de vales com avenidas e favelas, impermeabilizando cada vez mais o solo da metrópole, avançou por morros e áreas de proteção aos mananciais nas zonas Norte (Cantareira) e Sul (Guarapiranga e Billings).
}

BORELLI (2011) destaca que em 2003 mais de 50\% da área da Bacia Hidrográfica da Guarapiranga já estava alterada por atividades humanas, estando entre estas atividades os usos urbanos, representando $16 \%$ deste total, apresentando a bacia remanescentes de vegetação em apenas $37 \%$ de sua área total.

Hoje ainda se vê a complexidade com a qual se depara o poder público, tendo as moradias irregulares em áreas de proteção como propulsoras de degradação ambiental e proporcionando ambientes favoráveis a proliferação de doenças de veiculação hídrica por não haver saneamento básico. A maioria dos locais irregulares de população de baixa renda não consegue ser legalizado e com isso não é permitida a entrada de melhorias urbanas para aquela população. Esta dinâmica de urbanização constrói uma cadeia de consequências, percorrendo a segregação da população e sua qualidade de vida até os problemas de uso e ocupação do solo que permeiam as questões dos recursos hídricos, sendo eles prejudicados também, como discorre JACOBI (2013, p. 225) sobre o tema: "a ausência de saneamento em muitos loteamentos e favelas, além de poluir diretamente as águas dos rios e córregos, constitui um problema de saúde e de baixa qualidade de vida para a população residente, assim como a perda do valor das águas".

O número das moradias irregulares só cresce mesmo sendo possível ver claramente a diminuição do crescimento demográfico da RMSP nos últimos 25 anos, como disserta BONDUKI (2011, p. 25): 
A desigualdade urbana, funcional e social se aprofunda, gerando uma cidade partida e segregada. A mancha urbana se expande horizontalmente destruindo as áreas de proteção ambiental e gerando, por um lado, assentamentos precários distantes e carentes de infraestrutura, e, por outro, condomínios fechados de média e alta rendas, acessíveis apenas por meio de automóvel.(...) as áreas mais bem urbanizadas perderam população, enquanto as regiões mais distantes, as áreas de interesse ambiental e os municípios mais pobres da Região Metropolitana continuam com crescimento elevado.

Desta forma, as moradias que não possuem sistema de saneamento utilizam os rios e córregos como descarga de seus resíduos, sendo os esgotos domésticos os maiores causadores da poluição das águas na RMSP (JACOBI et al., 2015a).

Dentro da trama urbana, os corpos d'água acabam sendo esquecidos, cobertos, tornando-se empecilho para os moradores locais e deixados de lado pelos gestores dos recursos hídricos. BARTALINI (2006, p. 90) disserta sobre os cursos d'água que devido a suas pequenas dimensões e falta de representatividade na paisagem urbana acabam sendo esquecidos, tendo poucas soluções de melhorias:

Os únicos planos que atendem a esses cursos d'água são os de infraestrutura, que propõem, invariavelmente, sua canalização e tamponamento. Por força da urbanização há muito consolidada, é dado por inviável aplicar-lhes as restrições ambientais legais e, porque as oportunidades de intervenção parecem, à primeira vista, inexistentes, os programas de melhoramento da paisagem urbana nunca os contemplam.

\section{2. ÁGUA E SAÚDE PÚBLICA}

\subsubsection{DOENÇAS DE VEICULAÇÃO HÍDRICA}

Inicialmente os moradores da cidade de São Paulo utilizavam a água de fontes naturais, ribeirões e até mesmo de poços construídos. Com o crescimento da urbanização e aumento da população de São Paulo, a escassez no abastecimento de água intensificou a necessidade de obter alternativas que suprissem a demanda da população que não podia arcar com os altos custos de barris e sistemas de canalização.

Esta necessidade resultou na construção de chafarizes públicos no século XVIII. Os jesuítas foram os primeiros a construir um chafariz público na cidade com o auxílio de 
doações, no Largo da Misericórdia. No entanto, os chafarizes viraram alvos de brigas entre as pessoas que buscavam água para vender e as que necessitavam da água para sua sobrevivência, além de furtos das peças como canos e torneiras. Outro ponto negativo dos chafarizes era sua forma de utilização pela população, sendo estes utilizados de forma inadequada, passando a ser local de banhos e lavagem de roupas, o que depreciava a qualidade da água e trazia riscos à saúde da população (FARIA, 2004; SANT'ANNA, 2004; SANTOS, 2011.

Após o uso intenso e muitas vezes inadequado dos chafarizes, entre os anos 1875 e 1878 ocorreu a concessão de administração do saneamento básico à empresa privada Companhia Cantareira de Águas e Esgotos, e segundo o contrato, permitia o monopólio da venda de água e coleta de esgotos por 70 anos à companhia. Dez anos depois, cerca de 5.000 edifícios possuíam água. Porém, como consequência, diversos chafarizes espalhados pela cidade foram desativados, forçando a população de baixa renda a obter o serviço em suas residências, o que causou conflito devido ao custo que aquele serviço exigia. O que os responsáveis pela Companhia Cantareira não esperavam, era o crescimento da cidade na proporção que ocorreu, levando a companhia a uma crise econômica que resultou, em 1893, na transferência da responsabilidade do abastecimento e coleta de esgoto da Companhia Cantareira para o Governo do Estado (FARIA, 2004; SANTOS, 2011).

Em diversas partes do mundo, é observada a ocorrência de doenças vinculadas ao processo de urbanização, como ocorreu no Brasil entre o fim do século XIX e o início do século XX, sendo a grande massa de classes populares as mais atingidas. A cidade de São Paulo não foi uma exceção como descreve José Joaquim de Freitas, físcal de rios da capital em 1903, citado por JORGE (2012, p. 104), que descreve suas atividades e comenta o fato do rio Tietê ser o saneador, transportando "as imundices que lhe são confiadas", e sua preocupação com a grande carga exercida sobre o rio, já prevendo os riscos à saúde da população. Havia ainda as ilhas de lodo, citadas pelo fiscal, que eram formadas nas épocas de seca, quando ocorria a fermentação da matéria orgânica e consequente mau cheiro, o que atraia moscas e pernilongos, acreditando-se que estes problemas ocasionariam surtos de pestes à população.

Desta forma, ressalta-se as transformações ocasionadas pelo crescimento desordenado, além da falta de tratamento de esgoto, o que agrava a situação dos rios, trazendo a retificação dos mesmos, excluindo os seus meandros, a retirada das matas ciliares, a introdução de espécies exóticas, a criação de animais às margens dos rios, desconfigurando a paisagem e trazendo consequências agravadoras para a qualidade da água destes rios. LIBÂNIO et al. (2005, p. 220), expõem:

A contaminação das águas naturais representa um dos principais riscos à saúde pública, sendo amplamente conhecida a estreita relação entre a qualidade de água e inúmeras enfermidades que acometem as populações, especialmente aquelas não atendidas por serviços de saneamento. 
A maioria das doenças transmitidas pela água é causada por agentes patogênicos de origem entérica, animal ou humana, pertencentes ao grupo de organismos que se disseminam basicamente via fecal-oral, sendo transmitidos por água ou alimentos contaminados, podendo estes ser bactéria, vírus ou protozoário. Porém, alguns patógenos podem ser liberados na água através de feridas, lesões ou úlceras, tendo o uso recreativo papel importante nessa forma de disseminação, assim como na transmissão, podendo ocorrer infecções através do contato do patógeno com a mucosa do hospedeiro (GRABOW, 1996).

Em 1925, Geraldo Horácio de Paula Souza, logo após assumir o cargo de Diretor Geral do Serviço Sanitário do Estado, teve que enfrentar a epidemia de febre tifoide na capital paulista, a qual era ocasionada pelo abastecimento de água sem tratamento prévio retirada do rio Tietê. Com isso, propôs a cloração da água, que permitiu a redução de 65 mortes a cada 100.000 pessoas para menos de 10 mortes a cada 100.000 em 1930 (MASCARENHAS, 2006).

Em uma tabela apresentada por BUCHALLA et al. (2003) é possível observar o índice de mortalidade por doenças diarreicas e gastroenterite, as quais eram as principais causadoras de mortalidade em 1901, tendo seu maior pico na época da expansão da capital paulista e seus problemas com o saneamento básico (Tabela 2).

Tabela 2 - Mortalidade por doenças infecciosas ( ${ }^{\circ}$ absoluto e coeficiente / 100.000) no Município de São Paulo, 1901, 1960 e 2000.

\begin{tabular}{ccccccc}
\hline Doenças & $\mathbf{N}^{\circ}$ & Coef. & $\mathbf{N}^{\circ}$ & Coef. & $\mathbf{N}^{\circ}$ & Coef \\
\hline $\begin{array}{c}\text { Diarreia e } \\
\text { gastroenterites }\end{array}$ & 1005 & 351,40 & 1935 & 51,20 & 235 & 2,30 \\
$\begin{array}{c}\text { Febre tifoide e } \\
\text { paratifoide }\end{array}$ & 68 & 23,80 & 2 & 0,05 & - & - \\
$\begin{array}{c}\text { Febre amarela } \\
\text { Esquistossomose }\end{array}$ & 3 & 1,00 & - & - & - & - \\
\hline
\end{tabular}

Adaptado de: BUCHALLA et al. (2003).

Os primeiros casos de esquitossomose mansônica, doença de veiculação hídrica, registrados no município de São Paulo são datados do ano 1958 (SILVA, 1985). Segundo o autor, o alastramento desta doença está vinculada ao processo de urbanização com a falta de 
saneamento básico e a especulação imobiliária, fazendo com que a população de baixa renda se aloje cada vez mais nos lugares indesejados, próximos a rios, lagos e áreas alagáveis, áreas estas formadas, neste caso, não pelo ciclo natural dos rios, mas pela impermeabilização do solo.

Em pesquisa desenvolvida sobre a presença de enteroparasitoses em crianças com menos de 5 anos, realizada entre os anos de 1973 e 1974 na cidade de São Paulo, comprovouse que quase dois terços das crianças estavam com parasitas no intestino. Já a pesquisa realizada nos anos 1984 e 1985, demonstrou a redução de parasitoses nas crianças avaliadas, chegando-se a um resultado de um pouco mais de 30\% das crianças com menos de 5 anos residentes na cidade, com uma ou mais espécies de parasitas intestinais presentes no organismo. E entre os anos de 1995 e 1996, foi possível confirmar que uma a cada dez crianças com menos de 5 anos, estavam com parasitas intestinais em seus organismos. Segundo os autores, apesar do município ser considerado um centro industrial, ao contemplarmos as condições de moradia e saneamento é possível compreender a presença de enteroparasitoses, assumindo, desta forma, a relação entre o decréscimo evidenciado com a melhoria da infraestrutura urbana, o aumento da rede de saneamento básico na cidade e a maior facilidade ao acesso de medicamentos. (MONTEIRO et al., 1988; FERREIRA et al., 2000).

Não obstante, no levantamento feito por MONTEIRO e NAZÁRIO (2000, p. 18), relativo aos condicionantes ambientais que influenciam a saúde na infância nos anos de 1984 e 1996, é possível levantar a hipótese de que as alterações no meio onde vivem como rede de água e esgoto e esgoto a céu aberto, influenciam no seu "estado nutricional, o crescimento pondo-estatural e nas enfermidades" que atingem as crianças, como as enteroparasitoses intestinais. Em estudo realizado por FERREIRA et al. (2002) também foi levantada a questão do crescimento, tendo as crianças que apresentaram os piores desempenhos de crescimento duas ou mais espécies de parasitas no organismo.

Em estudo desenvolvido por LUDWIG et al. (1999) sobre a população da cidade de Assis, interior do Estado de São Paulo, entre os anos de 1990 - 1992 observa-se a relação existente entre a predominância de parasitoses intestinais e as condições de saneamento básico da população estudada. O estudo evidenciou a diminuição da presença de parasitoses na população que possui maior infraestrutura de saneamento, obtendo, desta forma, uma relação direta entre eles, além do fator social da população local. Assim como um estudo desenvolvido por BENICIO e MONTEIRO (2000) sobre a tendência de doença diarreica em crianças na cidade de São Paulo, que discute a ocorrência da doença com grau de exposição a enteropatógenos, os quais são determinados também pelo acesso à água tratada e saneamento básico.

Do mesmo modo, um estudo realizado por SILVA et al. (2005), na região de Campina Grande, Paraíba, observa a existência de enteroparasitoses em mais de $90 \%$ das crianças que participaram da pesquisa. As condições locais como: esgoto a céu aberto e a utilização de locais de desenvolvimento dos ciclos biológicos das enteroparasitoses como 
espaço de recreação por essas crianças são apontados como fatores que explicam o alto índice de indivíduos infectados.

MORAES e JORDÃO (2002, p. 372) estimaram que " $80 \%$ de todas as moléstias e mais de um terço dos óbitos dos países em desenvolvimento sejam causados pelo consumo de água contaminada, e, em média, até um décimo do tempo produtivo de cada pessoa se perde devido a doenças relacionadas à água".

GIATTI et al. (2004, p. 572) colocam que a questão das doenças parasitárias intestinais está "diretamente relacionada com as precariedades em saneamento básico e a consequente degradação ambiental", além da falta de orientação educativa essencial para a mudança de hábitos que evitem a transmissão dessas doenças, assim como apontou estudo realizado em Salvador, no qual foi amostrado um maior número de parasitas intestinais em crianças que estavam em situação socioeconômica baixa (LANDER et al., 2012).

Não obstante, ainda se tem as doenças de veiculação hídrica atreladas às enchentes e inundações, sendo elas as principais causadoras da disseminação de algumas doenças, como a leptospirose, por exemplo. Em levantamento feito por BASSO e RIGHI (2015, p. 82), para verificar a distribuição da doença no município de Porto Alegre entre 2007 a 2011, constatouse o aumento de casos da doença em períodos de inundações e maior suscetibilidade na população de baixa renda e moradores que habitam locais "com precariedade de instalações sanitárias e onde há presença de esgoto a céu aberto".

Desde as edições das leis estaduais de recursos hídricos, a partir do início da década de 1990, houve uma mudança na perspectiva da utilização dos recursos, agregando os aspectos quantitativos e qualitativos como dois pontos importantes na gestão e utilização das águas, o que contribuiu para que houvesse um aumento na "importância das questões situadas na interface entre as áreas de recursos hídricos e de saneamento", devido a sua relação com a saúde pública (LIBÂNIO et al., 2005, p. 220).

\subsubsection{CIDADES SAUDÁVEIS}

ROLNIK (1994) disserta que a cidade surgiu ante a possibilidade de produção de alimentos sem a necessidade de ir em busca do mesmo, produzindo-o a partir da agricultura e domesticação de animais. Porém, as grandes cidades não são produtoras agrícolas, mas sim consumidoras e isso só é possível devido ao excedente da produção de alimentos que ocorre em sua maior parte nas zonas rurais. Segundo a autora (1994, p. 15), "nas cidades contemporâneas não há praticamente nenhum espaço que não seja investido pelo mercado". $\mathrm{O}$ que nos leva ao tema ambiental, pois na maioria das vezes as questões ambientais são deixadas de lado pelos investidores e as áreas onde há pouca pressão imobiliária são muitas vezes invadidas pela população de baixa renda que não consegue competir por seu espaço nos locais de especulação, áreas estas que são tratadas como irregulares, não podendo haver estrutura básica de urbanização e saneamento. 
Com o crescimento exponencial das áreas urbanas, tanto horizontal quanto verticalmente, têm-se muitos problemas na esfera da poluição e contaminação do ecossistema urbano, sem falar no consumo excessivo gerando quantidades exorbitantes de resíduos que muitas vezes não são descartados da forma correta para reciclagem e aterros sanitários, e a poluição difusa e esgoto não tratado que afetam rios e córregos.

Iniciou-se um intenso questionamento sobre o processo saúde-doença na metade da década de 1970, que levou a novas concepções do processo, passando este a depender da união entre: "biologia humana, estilos de vida, meio ambiente e serviços de saúde". A partir disso, surgem visões sobre o assunto que ligam a saúde à condição de vida da população (MENDES, 1996, p. 236).

No final da década de 1970, no Canadá, iniciou-se o movimento que daria luz a concepção de Cidade Saudável devido ao debate sobre o que tornava as pessoas saudáveis ou não saudáveis, induzindo a conclusão de que os sistemas de saúde não eram suficientemente capazes de assegurar uma vida saudável à população, constatando que o estilo de vida e o ambiente influenciavam na saúde (MENDES, 2000; BRANDÃO, 2010).

A Carta de Ottawa, produzida em 1986, na I Conferência Internacional sobre Promoção da Saúde reconheceu diversos parâmetros como pré-requisitos necessários para a saúde. Dentre eles estavam: um ecossistema estável e os recursos sustentáveis, além de habitação, paz, educação, justiça social e equidade. A carta ainda cita a importância de criar ambientes favoráveis à promoção da saúde, assumindo a complexidade e inter-relação que há na sociedade e enfatiza que a conservação dos recursos naturais do mundo deveria ser de responsabilidade global.

Com a ampliação do significado do termo "promoção da saúde", houve a aceitação da saúde sendo de responsabilidade de diversos setores, havendo o entendimento da necessidade da gestão intersetorial para alcançar os objetivos propostos (FERRAZ, 1998).

A partir da problemática da sustentabilidade nas cidades e da relação que ela tem com a saúde da população, buscou-se empregar parâmetros que pudessem ser almejados e alcançados pelas cidades na tentativa de se obter uma cidade melhor, mais sustentável e que propusesse aos seus habitantes melhores condições de saúde física e mental.

A Organização Mundial da Saúde (OMS) aderiu à ideia e apresentou o conceito de Cidade Saudável no Primeiro Simpósio sobre Cidades Saudáveis, no ano de 1986 em Lisboa (MENDES, 2000). A OMS (1995) estabeleceu 11 características que devem ter as cidades para serem consideradas saudáveis buscando condições de saúde e qualidade de vida urbana melhores para a população. Dentre estas características, estão: "um ambiente físico limpo e seguro", "um ecossistema estável e sustentável a longo prazo", "cumprir necessidades básicas (comida, água, residência, renda, segurança e trabalho) para todos os cidadãos" e "nível ótimo de saúde apropriada e serviços sanitários acessíveis à todos". A OMS criou o projeto de cidades saudáveis com o objetivo de promover a inovação na política sanitária local, 
oferecendo novas propostas de saúde pública e criando ambientes mais saudáveis para a população.

Pode-se dizer que a proposta de Cidade Saudável está diretamente entrelaçada com as políticas públicas implantadas que buscam intervir não apenas no âmbito físico, mas também na mudança de comportamento dos cidadãos, trabalhando assim, com a relação entre o governo e a sociedade. E para que isso se perpetue, há a necessidade de assumir não um projeto, mas sim uma estratégia municipal que possa consolidar-se. Esta visão de trabalho tem como objetivo obter mudanças em longo prazo e permanentes levando a gestão pública a desenvolver políticas com uma estrutura intersetorial, rompendo as barreiras burocráticas, assumindo a saúde como um conjunto de diversos aspectos que nela interferem (ALMEIDA, 1997; KEINERT, 1997; MALIK, 1997).

MALIK (1997, p. 22) levanta a questão da busca por uma Cidade Saudável, podendo ela cumprir a função de uma causa a ser almejada ou uma consequência da mudança de comportamento de um todo, havendo um "envolvimento integral" dos cidadãos com os tomadores de decisão. Desta forma, conclui-se que a mudança de comportamento para um ambiente mais saudável deva vir de todos. Esta visão precisa ser difundida e aceita e é neste quesito que há o envolvimento maior de todos os setores da sociedade (educação, saúde, meio ambiente) e dos sujeitos sociais como pontua BRANDÃO (2010, p. 37-38)

\footnotetext{
Não é possível falar de espaço saudável se os sujeitos sociais não se sentem fazendo parte dele. Um município, para ser saudável, precisa ser amado pelas pessoas que lá habitam. Elas precisam compreender que aquele espaço lhes pertence e que, necessita ser cuidado por elas e pelos que elegem como sendo seus representantes.
}

A visão do espaço pertencendo ao habitante ainda precisa ser trabalhada em nossa sociedade. Há necessidade de promover o maior envolvimento da população com os elementos ambientais que habitam ao seu redor. BARTALINI (2006, p. 91) pontua que a questão dos corpos hídricos urbanos necessita de um entendimento mais profundo, uma relação mais sensível entre os seres humanos e a natureza, sendo possível "desenvolver a consciência e, em seguida, atitudes ambientalmente consequentes" depois dessa mudança de paradigma. ZANETI e SÁ (2002) defendem que com base na insustentabilidade que existe na relação entre os cidadãos com a natureza e seus resíduos, é indispensável que se invista em uma educação integrada, que transforme o posicionamento da população, havendo maior participação e envolvimento entre as pessoas e o ambiente ao seu redor. As autoras discutem a perda de conexão da população com os processos naturais e biológicos e as "necessidades inventadas" pelos dias atuais, perdendo a relação essencial com a natureza. Para FRACALANZA (2009) não só houve o distanciamento da população em relação aos rios, mas também houve alteração no uso da água, havendo atualmente maiores usos pela indústria 
e menores para esportes e lazer devido às modificações da paisagem, contribuindo no aumento da barreira homem-água e a perda de qualidade da água.

LAYRARGUES (2006) afirma que esta mudança cultural só será observada quando houver uma ética ecológica e um dever moral de proteger a natureza, não sendo apenas uma ação na qual o indivíduo utiliza os recursos naturais exclusivamente para sua sobrevivência e bem-estar. Devido à última crise hídrica ocorrida na cidade de São Paulo, percebeu-se uma mudança de comportamento da população em relação à economia da água, porém, esta mudança limita-se ainda na obtenção de água tratada e não na conservação dos recursos naturais para utilização como fonte de apreciação e cuidados com o ecossistema dos reservatórios.

A conexão dos habitantes com sua cidade transforma a participação, proporcionando um novo entendimento e posicionamento entre os cidadãos e seus representantes públicos, havendo maior cobrança para as melhorias ambientais e o surgimento de políticos engajados nestas melhorias. ADRIANO et al. (2000) defendem que o Movimento Cidades Saudáveis deve investir na participação social para que seja um processo permanente, sem interferências políticas, dando legitimidade política e social ao projeto.

BRANDÃO (2010, p. 39) propõe a "construção de municípios potencialmente saudáveis" a partir da relação entre gestão participativa, participação comunitária e reorientação dos serviços públicos. A proposta discute a gestão participativa dos representantes públicos da sociedade, devendo eles adquirir uma formação intersetorial, havendo a comunicação de várias secretarias, colocando em pauta questões técnicas e práticas para se alcançar os objetivos de uma cidade mais saudável; a participação comunitária organizada; e a reorganização dos serviços públicos (provindos do poder público, organizações não governamentais e entidades filantrópicas) de forma que os mesmos sejam articulados para o melhor atendimento aos cidadãos e não apenas articulados em esfera burocrática.

A visão intersetorial é fundamental para que ocorra a união da esfera pública de saúde com os outros setores para que estes possam trabalhar juntos em prol da melhoria da qualidade de vida dos cidadãos, produzindo um resultado concreto e contínuo, ultrapassando as fragmentações políticas causadas pela estrutura do modelo de gestão pública e tornando-se parte do sistema de gestão (WESTPHAL, 1997; ADRIANO et al, 2000).

Apesar do termo Cidade Saudável ser utilizado desde a sua criação, no âmbito internacional como "uma filosofia de ação, baseada em uma concepção ampla de saúde que incorpora além dos aspectos biológicos que interferem no processo saúde doença, os determinantes sociais, econômicos e ambientais", como cita WESTPHAL (1997, p. 12), no surgimento do movimento Cidade Saudável não havia o envolvimento de políticas que incorporassem esta definição como há atualmente. São exemplos o Estatuto da Cidade (Lei 10.257/2001) e a Política Nacional de Promoção da Saúde (Portaria 2.446/2014) que colocam o bem-estar em pauta, abrangendo ainda mais o termo e passando a outro nível de entendimento sobre Cidades Saudáveis (SPERANDIO et al., 2016). MATHIAS (2010, p. 89) 
apresenta como sendo alguns parâmetros de Cidade Saudável: "limpeza, segurança, alta qualidade física do meio ambiente, alto grau de participação pública e controle sobre decisões que afetam a vida, saúde e o bem estar" da população.

A fim de que o conceito de Cidade Saudável seja efetivo, é imprescindível que se tenha a visão da problemática urbana e ambiental como sendo resultado do meio a partir do seu histórico e da sociedade, definindo o problema a partir das "relações sociais e práticas espaciais que implicam diretamente nas formas de como o território é produzido e consumido" (PENNA, 2013, p. 3).

Compreende-se que não é viável considerar os problemas que envolvem uma cidade de forma isolada, assim como os problemas que envolvem a saúde da população, pois há uma relação entre todos os campos, exigindo da sociedade a interligação dos problemas complexos para que estes sejam resolvidos e para que seja possível alcançar os objetivos de uma Cidade Saudável (MENDES, 2000; MATHIAS, 2010).

A partir do que foi discutido, pode-se associar a relação de melhoria na qualidade de vida mental e física dos cidadãos quando há maior ligação com a natureza e com a água que está inserida na cidade, desde que a mesma seja vista como uma opção de lazer e apreciação.

Neste aspecto pode-se inserir a água como elemento importante para a saúde e bemestar dos habitantes. No entanto, o que se vê atualmente não é uma visão que valoriza os rios e córregos da cidade, mas sim que busca minimizar os efeitos negativos encobrindo, cercando e canalizando os mesmos para que possam se tornar invisíveis aos olhos dos cidadãos que se distanciam cada vez mais do aspecto benéfico da interação. BROCANELI (1995, p. 56) defende que:

Sendo a água um elemento importante na leitura dos processos ecossistêmicos, faz-se necessária a visualização e a valorização dos rios, lagos e córregos da cidade, pois o ressurgimento das águas na paisagem da cidade de São Paulo é um fator fundamental para o desenvolvimento sustentável.

ARAUJO e RIBEIRO (2015, p. 130) apresentam o questionamento sobre a "melhoria da qualidade dos rios urbanos" com base na degradação do meio e sua relação com a degradação social que ocorre nas áreas mais periféricas. Degradação esta que pode ser revertida com a valorização da paisagem a partir da recuperação da qualidade dos rios, tornando-os importante ferramenta da infraestrutura urbana. Há atualmente no mundo iniciativas que buscam restaurar os rios e córregos urbanos colocando-os como elemento central dentro dos projetos de revitalização de ambientes urbanos, como citam JACOBI et al. (2015a) sobre a River Revitalization Foundation, que reúne organizações da sociedade civil, cidadãos e o governo do local. 
Para que estes conceitos sejam alcançados, faz-se necessária a análise dos corpos d'água e a atenção dos comitês de bacia hidrográfica, inserindo-os nos programas e recuperando-os, elevando sua importância dentro do conceito de Cidade Saudável e fixandoos como parte da paisagem e não como um obstáculo.

\subsection{LEGISLAÇÃO E GESTÃO DAS ÁGUAS}

\subsubsection{LEGISLAÇÃO E GOVERNANÇA DOS RECURSOS HÍDRICOS NO BRASIL}

Ao retroceder para as constituições brasileiras editadas entre os anos 1824 a 1969, o trato das questões relacionadas aos recursos hídricos diz respeito especificamente ao domínio dos mesmos, mostrando que não havia ainda preocupação com sua quantidade e qualidade.

O crescimento do país e sua industrialização acelerada trouxeram em debate a questão da necessidade do desenvolvimento de hidrelétricas nos anos 1920, exigindo "medidas reguladoras", o que resultou na criação da Comissão de Estudos de Forças Hidráulicas na esfera do Ministério da Agricultura, Indústria e Comércio (RODRIGUES, 1998, p. 24).

Durante o governo Vargas foi criado o Código das Águas, por meio do Decreto $\mathrm{n}^{\circ}$ 24.643, de 10 de julho de 1934, que permitia ao governo fixar tarifas pelo uso da água (LUCENA, 1998). O Código das Águas tem como base a identificação de águas públicas e privadas, discriminando a maior parte das águas como pertencentes à União. Há também a caracterização das formas e localidades que podem ser encontradas, além de determinar as normas de como deve proceder a indústria de energia hidráulica pautando também suas concessões, autorizações, fiscalização e penalidades (BRASIL, 1934).

A criação do Código das Águas foi necessária pela falta de uma legislação sobre o uso das águas que estivesse de acordo com as necessidades da população, além das exigências de medidas que facilitassem e garantissem o aproveitamento das águas por hidrelétricas (BRASIL, 1934). RODRIGUES (1998, p. 25) explica que a sensação de que o Código das Águas foi dirigido unicamente para o setor elétrico ocorreu devido à omissão de outros setores que não sentiram "a necessidade de impor sua importância e fazer cumprir suas demandas".

POMPEU (2010) aponta que existem lacunas normativas no Código das Águas nos livros I - Águas em geral e sua propriedade e II - Aproveitamento das águas públicas, as quais seriam sanadas com a criação de leis e regulamentos complementares que só ocorreram com a criação da Lei $n^{\circ} 9.433$ em 1997. Desta forma o autor aponta a necessidade de rever a aplicabilidade destas partes do Código já que o livro III - Forças hidráulicas - regulamentação da indústria hidroelétrica, recebeu constante atualização por meio de atos complementares ao longo dos anos. 
O início da legislação brasileira com ênfase ambiental teve como base oferecer diretrizes aos indivíduos, proteger sua saúde e repartir os recursos naturais mais utilizados (POMPEU, 2010). Com isso, objetivava-se proteger os recursos naturais e não o ambiente em si. Esta forma de pensamento trouxe consequências graves ao longo do tempo, resultando apenas em 1973 em atitudes que visavam a qualidade ambiental. Nesta sequência, houve a criação da Secretaria Especial do Meio Ambiente (SEMA) e com ela a criação de legislação ambiental, como cita POMPEU (2010, p. 135) a respeito do II Plano Nacional de Desenvolvimento (PND-II 1975-1979):

\footnotetext{
Declarando ser importante o combate à poluição, o documento previa uma política de meio ambiente destinada à área urbana, para evitar ações poluidoras do ar e da água, e uma política para a proteção dos recursos naturais, visando à correta utilização do ar, da água, do solo, do subsolo, da flora e da fauna, o controle da poluição industrial e a instituição de programas especiais de preservação do meio ambiente.
}

A Constituição de 1988 (CF/88), no artigo 225, dissertou sobre o meio ambiente em equilíbrio visando "assegurar a efetividade do direito de todos ao meio ambiente ecologicamente equilibrado", além de exigir a abstenção de atos nocivos ao meio ambiente, garantindo a preservação ambiental e ao que se referisse aos recursos hídricos (BRASIL, 1988). Mais uma alteração importante introduzida pela Constituição foi a instituição do sistema nacional de gerenciamento de recursos hídricos, atribuído à União (SETTI et al., 2001; PORTO e PORTO, 2008).

REZENDE (2003, p. 139) disserta sobre as discussões ocorridas na década de 1990 sobre as questões ambientais urbanas discutidas na Conferência das Nações Unidas (UNCED) para o Meio Ambiente, em 1992, nas quais são consideradas prioritárias as relações entre o crescimento urbano e a proteção ambiental, buscando a criação de políticas públicas urbanas que prezem não só pelo crescimento das cidades, mas também pelo seus recursos naturais.

A Lei Federal $n^{\circ}$ 9.433, de 08 de janeiro de 1997, instituiu a Política Nacional de Recursos Hídricos (PNRH) e criou o Sistema Nacional de Gerenciamento de Recursos Hídricos (SNGRH). Esta Lei trouxe a visão de gestão descentralizada, o reconhecimento da água como bem finito e vulnerável, o incentivo à racionalização, o objetivo do planejamento, da regulação e do controle do uso, além da preservação e recuperação dos recursos hídricos (BRASIL, 1997; RODRIGUES, 1998; SETTI et al., 2001).

Tendo a bacia hidrográfica como unidade territorial para a gestão dos recursos hídricos, a PNRH “(...) rompe com as tradicionais fronteiras físico-políticas dos estados, exigindo uma integração entre os poderes municipal, estadual e federal (...). Propõe uma política participativa e um processo decisório aberto aos diferentes atores sociais vinculados ao uso da água (...).” (JACOBI, 2004, p. 273). RIBEIRO (2009, p. 126-127) levanta algumas 
questões sobre o recorte em bacias hidrográficas devido a sua complexidade e à dimensão da política socioambiental necessária à sua gestão:

Este sistema é complexo, pois combina elementos dinâmicos, como a pluviosidade e o clima, que atuam sobre a litologia, sobre o solo e sua cobertura, seja ela natural ou produzida. No caso de um espaço produzido, tanto agrícola quanto urbano, as ações das águas podem ser benéficas, como a irrigação, mas podem também gerar situações de risco, em especial em fundos de vale ocupados em cidades. Portanto, analisar uma bacia hidrográfica remete necessariamente ao uso do solo de sua área, que deve ser avaliado à luz da capacidade de reposição hídrica.

Segundo SETTI at al. (2001, p. 102), iniciaram-se as discussões sobre o SNGRH em 1987 na Associação Brasileira de Recursos Hídricos (ABRH) e se estenderam ao longo dos anos em "dezenas de encontros, workshops e seminários, realizados em todo país”, até a criação da lei. Entre os objetivos do SNGRH está a coordenação da gestão integrada das águas e para que este objetivo pudesse ser alcançado, foram criados organismos dentro do arranjo institucional, sendo eles: o Conselho Nacional de Recursos Hídricos (CNRH), os comitês de bacias hidrográficas, as agências de água e as organizações civis de recursos hídricos. Estes organismos seguem hierarquia segundo Figura 3.

Figura 3- Estrutura do Sistema Nacional de Gerenciamento de Recursos Hídricos.

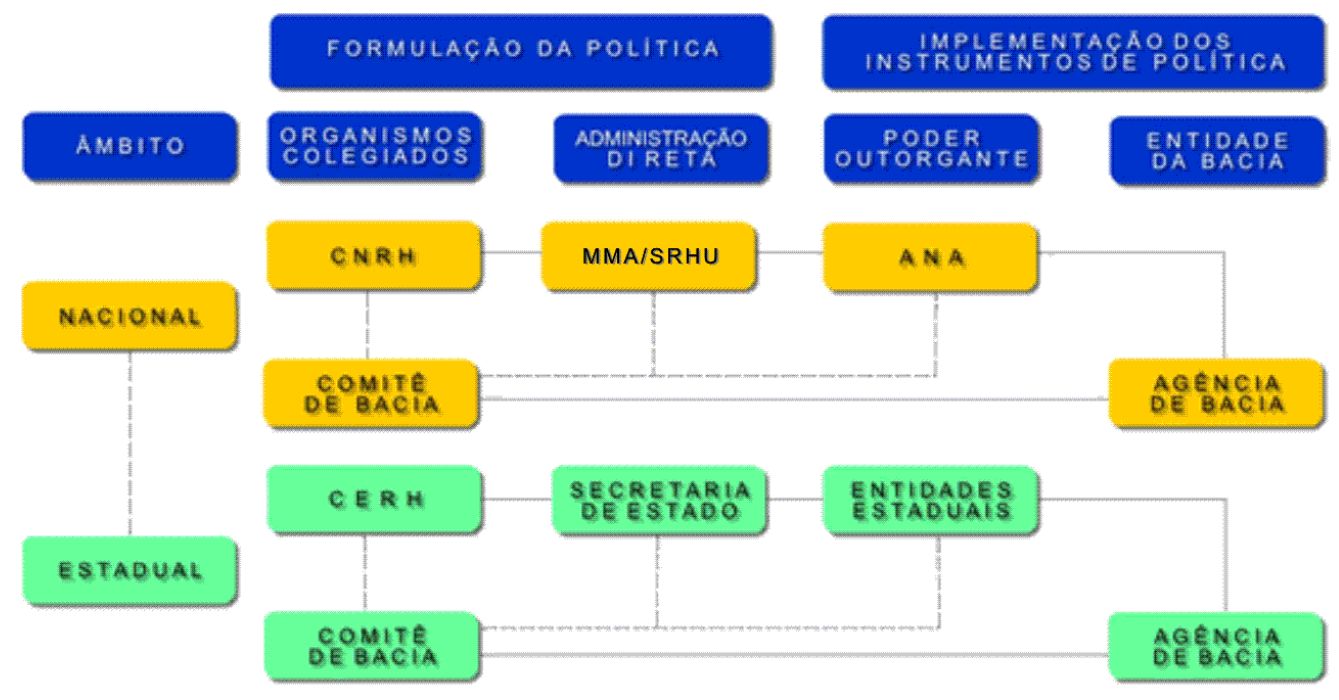

Fonte: Ministério do Meio Ambiente (MMA), 2016.

Segundo o MMA (2016), compete aos conselhos nacional e estaduais (CNRH e CERH) - subsidiar a formulação da Política de Recursos Hídricos; ao MMA e à Secretaria de 
Recursos Hídricos e Ambiente Urbano (SRHU) - formular a PNRH e subsidiar a formulação do Orçamento da União; a Agência Nacional da Água (ANA) - implementar o SNGRH, outorgar e fiscalizar o uso dos recursos hídricos de domínio da União; entidades estaduais outorgar e fiscalizar o uso dos recursos hídricos de domínio do Estado; ao comitê de bacia decidir sobre o Plano de Recursos Hídricos; e a Agência da Água - atuar como escritório técnico da bacia.

Dentro desta dinâmica estrutural que permeia os recursos hídricos, a participação e a descentralização nas decisões tangem apenas a gestão desses recursos, não alcançando ainda as questões de uso e apropriação da água, temas estes essenciais para a análise socioambiental (FRACALANZA, 2009).

É necessário citar o Estatuto da Cidade, Lei Federal n 10.257, de 10 de julho de 2001, sendo ele a primeira política urbana que traz o conceito de sustentabilidade em nível federal, como aponta REZENDE (2003). Segundo o artigo 2, inciso I, a política tem como um de seus objetivos a "garantia do direito a cidades sustentáveis, entendido como o direito à terra urbana, à moradia, ao saneamento ambiental, à infraestrutura urbana, (...), para as presentes e futuras gerações" dando desta forma engajamento as políticas urbanas atreladas as questões ambientais. Deste modo, com o Estatuto da Cidade e a utilização adequada do Zoneamento Municipal é possível prevenir os impactos ambientais decorrentes do crescimento urbano e do uso e ocupação do solo (PIZELLA, 2015), desde que estes sejam cumpridos de forma plena, o que não é encontrado ainda nas cidades.

\subsubsection{LEGISLAÇÃO E GESTÃO DOS RECURSOS HÍDRICOS NO ESTADO DE SÃO PAULO}

O Estado de São Paulo foi pioneiro na estruturação da gestão dos recursos hídricos com o Decreto $\mathrm{n}^{\circ}$ 27.576, de 11 de novembro de 1987, que criou o Conselho Estadual de Recursos Hídricos junto à Secretaria de Obras com o objetivo de estruturar a política relativa aos recursos hídricos, criar o Sistema Estadual de Gestão dos Recursos Hídricos e elaborar o Plano Estadual de Recursos Hídricos (SÃO PAULO, 1987).

No mesmo ano da CF/88 foi criada a Lei $n^{\circ} 6.134$, de 2 de junho. Esta lei disserta sobre a preservação das águas subterrâneas levando-se em consideração a interação entre águas subterrâneas e superficiais, exigindo a preservação e conservação dessas águas (SÃO PAULO, 1988). Três anos depois, um decreto ( $\left.\mathrm{n}^{\circ} 32.955 / 91\right)$ foi lançado regulamentando a Lei $n^{\circ}$ 6.134, dissertando definições e atribuições aos órgãos responsáveis para seu melhor cumprimento (SÃO PAULO, 1991a).

MARCONDES e ANDRADE (2005) discorrem que na década de 1980, ainda havia a centralização das decisões a respeito dos recursos hídricos no Estado de São Paulo, porém iniciava-se uma movimentação de técnicos e ambientalistas para que a participação da população civil fosse mais ativa em relação à gestão das águas, tornando-a mais democrática, participativa e descentralizada. 
O Estado de São Paulo, após o Decreto n ${ }^{\circ} 32.954$, de 7 de fevereiro de 1991, aprovou as diretrizes para a construção do primeiro Plano Estadual de Recursos Hídricos e estabeleceu a Lei $n^{\circ} 7.663$, em 30 de novembro do mesmo ano. Esta lei constitui normas de orientação sobre a Política Estadual de Recursos Hídricos, assim como para o Sistema Integrado de Gerenciamento de Recursos Hídricos que foi promulgado, iniciando o processo de discussão e produção dos primeiros Planos de Bacia no Estado, com os quais seria produzido o Plano Estadual de Recursos Hídricos (SÃO PAULO, 1991b; SETTI et al., 2001; MARCONDES e ANDRADE, 2005). Desta forma, foi possível envolver diversos setores da sociedade nas decisões sobre a bacia (GOMES e BARBIERI, 2004, p. 12):

O Estado é convidado a abandonar o seu papel autoritário e paternalista, detentor de todo o poder decisório, passando a compartilhar suas tradicionais responsabilidades com os usuários de recursos hídricos, governos municipais e outras formas de organização da sociedade, como sindicatos e entidades não-governamentais.

Com a necessidade da criação dos planos das bacias, em 18 de maio de 1993, o governador do Estado estabeleceu por meio do Decreto $n^{\circ} 36.787$, os representantes que deveriam fazer parte do Conselho Estadual de Recursos Hídricos e segmentou o Estado em vinte e duas Unidades de Gerenciamento de Recursos Hídricos (UGRHI's) como exibe a Figura 4.

Figura 4 - Divisão do Estado de São Paulo das Unidades de Gerenciamento de Recursos Hídricos.

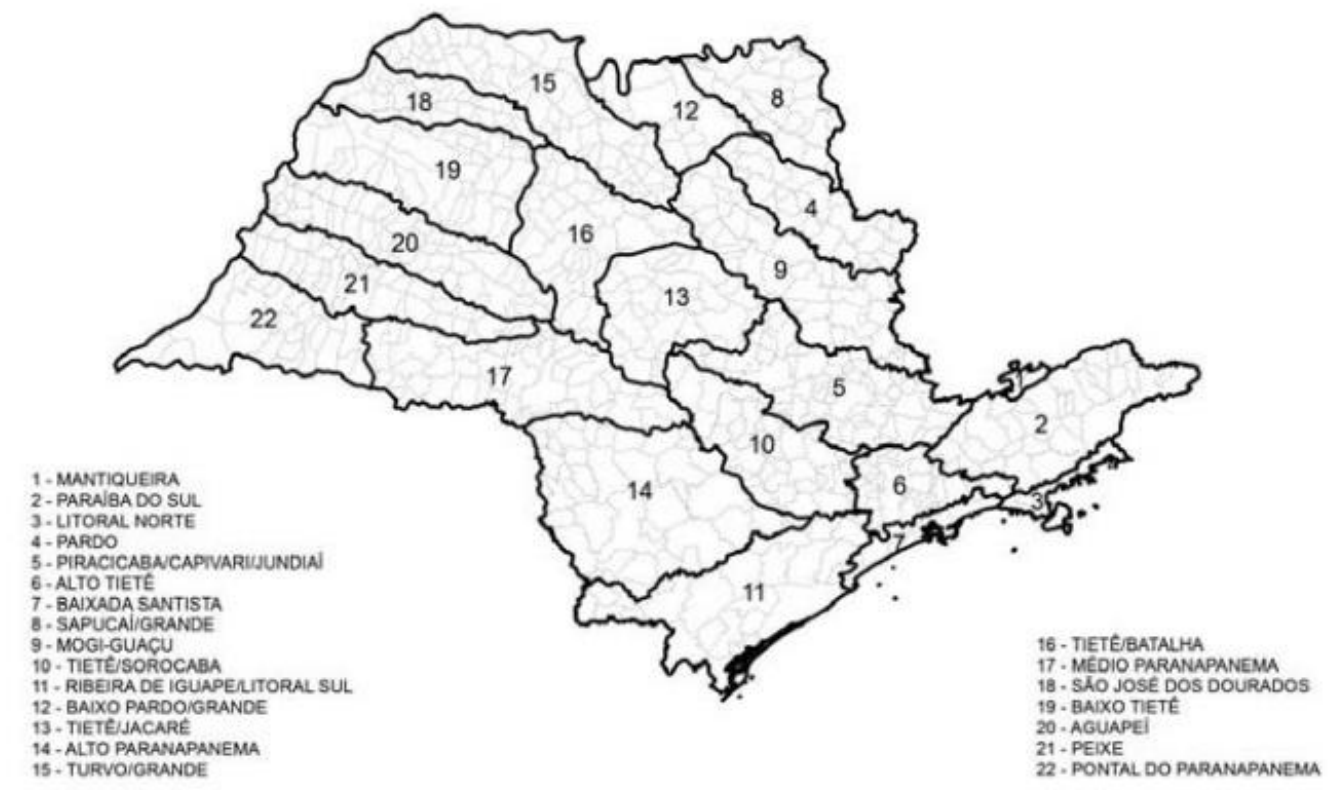

Fonte: Lei Estadual n ${ }^{\circ}$ 16.337/16. 
Nesta sequência, após a criação das UGRHI's, em 27 de dezembro de 1994 foi fixada a Lei Estadual $n^{\circ}$ 9.034, que dispõe sobre o Plano Estadual de Recursos Hídricos, atualmente revogada pela Lei Estadual 16.337, de 14 de dezembro de 2016.

Em 1997 foi criada a Lei $\mathrm{n}^{\circ} 9.866$ que disserta sobre normas para a proteção e recuperação dos mananciais de interesse regional e que objetiva a descentralização do planejamento e gestão da bacia, além da integração entre preservação do meio ambiente e desenvolvimento socioeconômico (SÃO PAULO, 1997, artigo 2). No ano seguinte, com o Decreto Estadual $\mathrm{n}^{\circ}$ 43.022, de 7 de abril de 1998, foram regulamentados os dispositivos relativos ao Plano Emergencial de Recuperação de Mananciais da RMSP, citado no artigo 47 da Lei $n^{\circ}$ 9.866/97 (SÃO PAULO, 1998). A partir desses dispositivos legais, foi possível a criação das leis específicas para cada Área de Proteção e Recuperação dos Mananciais (APRM's). Segundo dados coletados das atas do CBH-AT, houve muita discussão sobre o tema e pressão para que tais leis fossem estabelecidas.

São Paulo criou seu Conselho Estadual de Recursos Hídricos (CRH) por meio do Decreto $\mathrm{n}^{\circ} 27.576$, de 11 de novembro de 1987, o qual foi adaptado pelo Decreto 57.113, de 7 de julho de 2011, possuindo 33 membros e 33 suplentes, conforme Quadro 1. Há ainda o Comitê Coordenador do Plano Estadual de Recursos Hídricos (CORHI), criado com o objetivo de auxiliar o CRH e os Comitês de Bacia Hidrográfica (CBH's). O CORHI coordena a elaboração do Plano Estadual de Recursos Hídricos e introduz as propostas dos planos das bacias hidrográficas elaborados pelos respectivos comitês no Plano Estadual.

Quadro 1 - Composição do Conselho Estadual de Recursos Hídricos.

\begin{tabular}{|c|c|}
\hline $\begin{array}{l}\text { ESTADO } \\
\text { Titulares ou } \\
\text { representantes das } \\
\text { secretarias }\end{array}$ & $\begin{array}{l}\text { - } \text { Saneamento e Recursos Hídricos (presidente); } \\
\text { - } \quad \text { Eeio Ambiente (vice-presidente); } \\
\text { - } \quad \text { Planejação; } \\
\text { - } \quad \text { Agricultura e Abastecimento; } \\
\text { - Saúde; } \\
\text { - Logística e Transportes; } \\
\text { - Desenvolvimento Econômico, Ciência e Tecnologia; } \\
\text { - Fazenda; } \\
\text { - Energia; } \\
\text { - Desenvolvimento Metropolitano. }\end{array}$ \\
\hline $\begin{array}{c}\text { MUNICÍPIO } \\
\text { Onze representantes } \\
\text { dos municípios } \\
\text { situados nas } \\
\text { Unidades de } \\
\text { Gerenciamento de } \\
\text { Recursos Hídricos } \\
\text { agrupadas por: }\end{array}$ & $\begin{array}{l}\text { - } \text { Alto Tietê; } \\
\text { - } \quad \text { Paraíba do Sul e Serra da Mantiqueira; } \\
\text { - } \quad \text { Ribeira de Iguape/Litoral Sul e Alto Paranapanema; } \\
\text { - } \quad \text { Médio Paranapanema e Pontal do Paranapanema; } \\
\text { - } \quad \text { Aguapeí, Peixe e Baixo Tietê; } \\
\text { - Tietê/Jacaré e Tietê/Batalha; } \\
\text { - } \quad \text { Turvo/Grande e São José dos Dourados; } \\
\text { - } \quad \text { Pardo e Mogi-Guaçu; } \\
\text { - Sorocaba/Médio Tietê e Piracicaba, Capivari e Jundiaí. }\end{array}$ \\
\hline
\end{tabular}


Quadro 1 - Composição do Conselho Estadual de Recursos Hídricos.

Continuação

\begin{tabular}{|c|c|}
\hline $\begin{array}{l}\text { SOCIEDADE CIVIL } \\
\text { Onze representantes } \\
\text { da sociedade civil dos } \\
\text { segmentos: }\end{array}$ & $\begin{array}{l}\text { - Um de usuários industriais de recursos hídricos; } \\
\text { - Um de usuários agroindustriais de recursos hídricos; } \\
\text { - Um de usuários agrícolas de recursos hídricos; } \\
\text { - Um de usuários de recursos hídricos do setor de geração de energia; } \\
\text { - Dois usuários de recursos hídricos para abastecimento público; } \\
\text { - Três de associações especializadas em recursos hídricos, de entidades } \\
\text { associativas de profissionais de nível superior relacionadas com recursos } \\
\text { hídricos; } \\
\text { Dois de entidades ambientalistas ou de entidades de defesa de interesses } \\
\text { difusos. }\end{array}$ \\
\hline
\end{tabular}

Fonte: Decreto ${ }^{\circ} 57.113 / 11$.

Os recursos financeiros para execução dos objetivos dos planos são provenientes do FEHIDRO, o qual é supervisionado e gerido pelo Conselho de Orientação de Fundo Estadual de Recursos Hídricos (COFEHIDRO), regulamentado pelo Decreto Estadual $n^{\circ}$ 48.896/04. Estes recursos disponibilizados pelo FEHIDRO são provenientes da arrecadação da cobrança pelo uso dos recursos hídricos, sendo ele alocado para as Unidades de Gerenciamento de Recursos Hídricos (UGRHI) e para os CBH's. Segundo o último Relatório de Atividades do FEHIDRO, de 2016, foram disponibilizados aproximadamente R \$ 3,6 milhões ao CORHI para financiar empreendimentos do âmbito estadual e R\$ 63,6 milhões para os CBH's, tendo a CBH-AT um investimento de R\$ 19,2 milhões, equivalente a 20\% - Gráfico 3 (SigRH, 2016).

Gráfico 3 - Porcentagem dos recursos disponibilizados pelo FEHIDRO por Comitê de Bacia Hidrográfica do Estado de São Paulo em 2016.

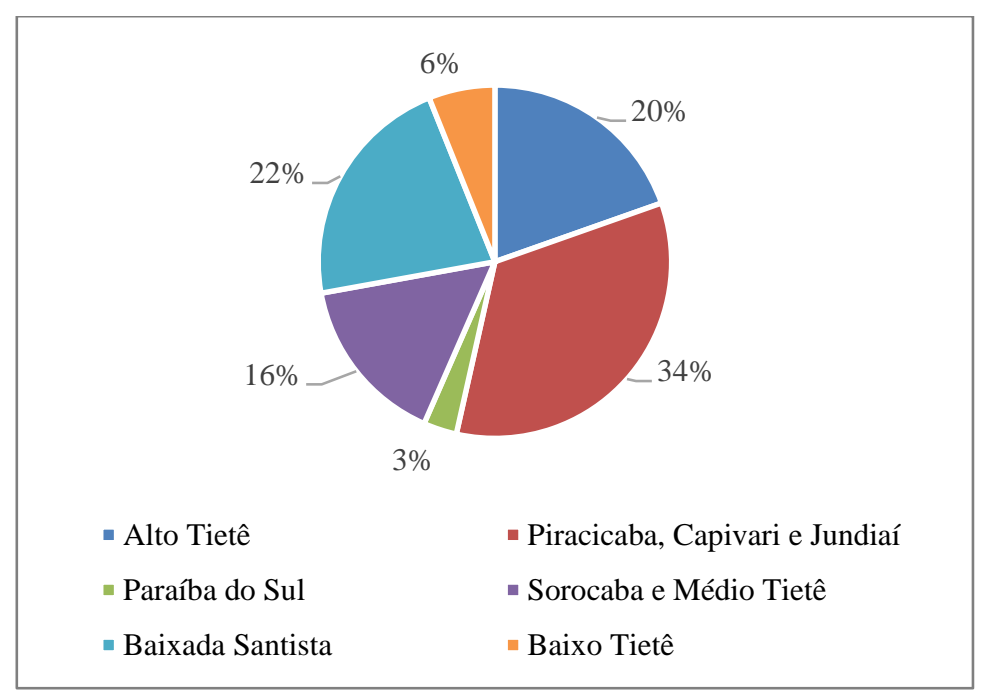

Fonte: Criado pela autora com base em dados da SigRH , 2016. 
O COFEHIDRO possui formação tripartite, tendo 12 conselheiros sendo eles: quatro membros representando os municípios indicados entre os componentes do $\mathrm{CRH}$; quatro membros representando as entidades da sociedade civil, também indicados pelos componentes do CRH; o secretário de Energia, Recursos Hídricos e Saneamento (presidente); secretário do Meio Ambiente (vice-presidente); secretário de Economia e Planejamento; secretário da Fazenda. Os secretários podem indicar representantes para substituí-los dentro do COFEHIDRO. Além dos conselheiros, o COFEHIDRO conta com uma rede de colaboração com secretarias executivas e agentes técnicos credenciados dos seguintes órgãos (Decreto Estadual $n^{\circ} 48.896 / 04$, artigo $3^{\circ}$ ):

a) Departamento de Águas e Energia Elétrica - DAEE;

b) Companhia de Tecnologia de Saneamento Ambiental - CETESB;

c) Coordenadoria de Planejamento Ambiental Estratégico e Educação Ambiental, da Secretaria do Meio Ambiente;

d) Coordenadoria de Assistência Técnica Integral - CATI, da Secretaria de Agricultura e Abastecimento;

e) Fundação para a Conservação e a Produção Florestal do Estado de São Paulo, da Secretaria do Meio Ambiente;

f) Instituto de Pesquisas Tecnológicas do Estado de São Paulo S.A. IPT, da Secretaria da Ciência, Tecnologia, Desenvolvimento Econômico e Turismo.

Apesar dos avanços na legislação e gestão dos recursos hídricos, OLIVEIRA FILHO (2015) aponta que existem falhas no sistema, necessitando ainda de amadurecimento institucional para que seja alcançada a execução da gestão integrada articulada em sua forma plena, possibilitando maior rapidez no planejamento e execução de ações e intervenções de melhoria. Além disso, a participação da sociedade carece ainda de progressos em torno da ambiguidade dessa participação que inclui a sociedade civil nos espaços de discussão, porém esta inclusão depende da atualização e disponibilidade do governo que gerencia os recursos hídricos, constituindo ainda hoje a participação voltada aos interesses dos grupos que participam dos comitês e não aos interesses da sociedade como um todo, sendo necessário a implantação de práticas que conciliem "participação com heterogeneidade" (JACOBI, 2004, p. 275; JACOBI et al., 2015b). Porém, esta participação com heterogeneidade depende também da mudança cultural em relação a visão negativa que a população possui dos espaços de debate, provinda da falta de confiança em seus políticos e nas instituições, vendo que a maior credibilidade na tomada de decisões encontra-se voltada à opinião do corpo técnico, limitando "o envolvimento da comunidade nas atividades dos comitês" (JACOBI, 2004; JACOBI, 2005, p. 83). RIBEIRO pontua a necessidade de haver representatividade na participação dos representantes da sociedade, sendo este interlocutor das demandas provindas da comunidade e aponta que (2009, p. 114): 
Um sistema de governança necessita da presença de diversos sujeitos sociais que atuam em várias escalas de poder político. Identificá-los, bem como a teia de relações multiescalares que repercutem no problema e no seu encaminhamento, é a primeira ação de um investigador voltado à compreensão da luta política em torno dos recursos hídricos quando ocorre a participação social.

Devido às divergências de interesses encontradas entre os membros dos CBH's e aos objetivos diversos que cada ator apresenta, há muita discussão e relação de interesses entre os membros, existindo assim, uma negociação entre diferentes atores levando-se em consideração os fatores econômicos, sociais e políticos (JACOBI, 2005). Desta forma, as decisões possuem uma "dinâmica de forças políticas e econômicas, bem como a legitimidade dos governos e das instituições diante das populações por elas governadas". (GOLDENSTEIN e SALVADOR, 2005, p. 89).

Uma problemática muito discutida é a falta da gestão integrada de bacias hidrográficas que se localizam em mais de um Estado, havendo muitas divergências sobre sua utilização e preservação. Em estudo realizado por SILVA e PORTO (2003), ficou clara a necessidade da implementação de uma gestão integrada entre o município e o gestor dos recursos hídricos. Apesar da ocupação do solo nas áreas de mananciais influenciarem diretamente a qualidade da água, é de responsabilidade do município este disciplinamento e sem a integração das duas partes, não é possível manter um sistema de gestão adequado no entorno dos mananciais. 


\section{CAPITULO 2 - ESTUDO DE CASO - BACIA HIDROGRÁFICA DO ALTO TIETÊ}

\subsection{ABORDAGEM METODOLÓGICA}

Para que seja possível uma análise crítica sobre as preocupações e ações do CBH-AT, será necessária uma primeira etapa de pesquisa bibliográfica e análise de atas e deliberações datadas a partir do ano de 1994 (ano de criação do comitê) até 2016, juntamente com análise dos projetos aprovados para receber recursos financeiros do FEHIDRO. O detalhamento dos assuntos tratados, dos projetos colocados em pauta e dos projetos financiados, permitirão avaliar o grau de importância dos córregos da região metropolitana.

Diante do tema proposto neste trabalho e da extensão das atas, foram delimitados assuntos pertinentes a despoluição ou preservação de rios e córregos sendo eles: abastecimento, poluição, despoluição, melhorias da qualidade da água, uso e ocupação do solo, destinação de recursos financeiros, educação ambiental e demais temas que envolviam a qualidade ou recuperação de corpos hídricos.

A partir da leitura integral das atas, foram criados quadros separados por ano com o dia da reunião, os temas relevantes ou discutidos e o detalhamento destes temas. Em reuniões que foram encontrados assuntos delimitados pela pesquisa, adicionou-se apenas eles nos temas e no detalhamento das reuniões. Já aquelas que não contavam com estes tópicos, foram adicionados os assuntos discutidos ou as atividades realizadas para quesito de acompanhamento da frequência dos tópicos considerados importantes para a despoluição dos corpos hídricos.

Já as deliberações foram todas anexadas nos quadros por ano, independentemente de sua descrição, assim como os projetos que receberam recursos do FEHIDRO. Tanto os dados das deliberações como dos projetos do FEHIDRO foram filtrados de acordo com os temas citados acima e, quando pertinente, adicionados aos resultados.

Todos as citações relacionadas aos assuntos delimitados encontrados nas atas do CBHAT constam no Anexo A - Síntese das Atas do Comitê de Bacia Hidrográfica, sendo eles sintetizados no Capítulo 3, assim como estão citados os projetos indicados pelas deliberações do CBH-AT e os contemplados com recursos do FEHIDRO, quando pertinente. A descrição de todas as deliberações e os dados de todos os projetos aprovados pelo FEHIDRO estão nos Anexo B - Deliberações do Comitê de Bacia Hidrográfica do Alto Tietê e Anexo C - Síntese de Projetos Aprovados para Recebimento de Recursos do FEHIDRO, respectivamente.

A síntese dos tópicos discutidos nas reuniões e as deliberações aprovadas pelo comitê, assim como a verificação da destinação dos recursos financeiros, possibilitou a análise da visibilidade dos rios e córregos da RMSP dentro do CBH-AT. 


\subsubsection{TIPO DE ESTUDO}

O trabalho se caracteriza como estudo de caso qualitativo, de caráter exploratório.

A pesquisa qualitativa pretende trazer ao texto diversas interpretações de um mesmo tema, buscando uma variedade de fontes consideráveis que permita a análise geral, não havendo a utilização de pesquisa traduzida em números, sendo o ambiente natural a fonte direta utilizada para coleta de dados (SILVA e MENEZES, 2005; DALFOVO et al., 2008).

Sabe-se que há diversas fontes a respeito da gestão dos recursos hídricos no Estado de São Paulo, porém há a necessidade de aprofundar os assuntos sobre a gestão com relação aos córregos da área urbana da RMSP.

O caráter exploratório propõe a investigação de um objeto de estudo que possua poucas informações, buscando trazer um panorama mais abrangente a respeito do tema (DALFOVO et al., 2008; SAMPIERI et al., 1991). Segundo GIL (2007, p. 43), "as pesquisas exploratórias têm como principal finalidade desenvolver, esclarecer e modificar conceitos e ideias, tento em vista, a formulação de problemas mais precisos ou hipotéticos pesquisáveis para estudos posteriores".

GODOY (1995), disserta à respeito da pesquisa qualitativa de caráter exploratório da seguinte forma: "quando estamos lidando com problemas pouco conhecidos e a pesquisa é de cunho exploratório, este tipo de investigação parece ser o mais adequado".

Do ponto de vista dos procedimentos técnicos, será realizada uma pesquisa bibliográfica e documental.

A pesquisa documental, segundo MARCONI e LAKATOS (2003) refere-se aos documentos de:

- Fontes primárias - compilados pelo autor;

- Fontes secundárias - obtidos a partir de fontes primárias;

- Fontes contemporâneas - documentos de arquivos públicos e censos; e

- Fontes retrospectivas - descritos pelo indivíduo que vivenciou.

Desta forma, pode-se concluir que serão utilizadas fontes secundárias e contemporâneas no decorrer da pesquisa. Sendo as fontes secundárias compostas por atas e deliberações.

GIL (2007) disserta sobre as vantagens da pesquisa bibliográfica e documental, exaltando a cobertura de investigação que permite uma maior compreensão do tema.

\subsubsection{DELIMITAÇÃO DA PESQUISA}

Foram levantados e analisados dados secundários sobre os corpos hídricos urbanos da Bacia Hidrográfica do Alto Tietê, buscando averiguar a atenção dada os mesmos pelos 
gestores a partir do ano 1994, devido a criação do Comitê de Bacia Hidrográfica do Alto Tietê, objeto do estudo.

\subsection{ASPECTOS GERAIS DA BACIA HIDROGRÁFICA DO ALTO TIETÊ}

A Bacia Hidrográfica do Alto Tietê (BH-AT), conforme estabelecido pelo Plano Estadual de Recursos Hídricos, é composta por uma área de drenagem de 5.868 km² e 6.570 $\mathrm{km}^{2}$ de extensão territorial, contando com quase cem tributários, os quais possuem grande importância em relação à drenagem e a representavidade nas cidades, como mostra a Figura 6, onde estão inseridos os principais cursos d'água e reservatórios. Dentro da BH-AT tem-se integralmente as sub-bacias dos reservatórios Billings e Guarapiranga (CBH-AT, 2009a; CBH-AT, 2014a).

Os principais rios da BH-AT são: "Tietê, Pinheiros, Tamanduateí, Claro, Paraitinga, Jundiaí, Biritiba-Mirim, Taiaçupeba-Açu, Guaió, Baquirivú-Guaçu, Cabuçu de Cima, Cabuçu de Baixo, Juqueri, Itaquera, Jacu, Aricanduva, Ribeirões: Meninos, Couros e Córrego Pirajussara" (CBH-AT, 2016, p. 37). O rio Tietê está inserido desde os munícipios de Salesópolis e Paraibuna, onde encontram-se as suas nascentes, até a Barragem de Rasgão, limite da BH-AT. Neste percurso, o rio é atingindo por vasta densidade urbana e demográfica com desordenado crescimento e ocupação do solo (CBH-AT, 2009a; CBH-AT, 2014a).

Estão entre os principais reservatórios da BH-AT: Paraitinga, Ribeirão do Campo, Ponte Nova, Biritiba-Mirim, Jundiaí, Taiaçupeba, Billings, Guarapiranga, Pirapora, Represas do Sistema Cantareira e Pedro Beicht (CETESB, 2016b).

A BH-AT está inserida no Bioma Mata Atlântica, o qual possui extrema fragilidade diante das interferências antropológicas ocorridas na região. Desta forma, as áreas protegidas com remanescentes florestais e as quarenta e uma unidades de conservação possuem papel fundamental na manutenção e preservação da biodiversidade e na conservação dos recursos hídricos (CBH-AT, 2016). As sub-regiões da BH-AT estão distribuídas nos subcomitês formados a partir de 1997, tendo atualmente cinco subcomitês e estrutura com Câmaras Técnicas e Grupos de Trabalho (Figuras 5 e 7) que compõem a rede de bacias inseridas no município de São Paulo e que fazem divisa com outros municípios (SigRH, 2015; CBH-AT, 2016):

- Subcomitê Tietê-Cabeceiras: Arujá, Biritiba-Mirim, Ferraz de Vasconcelos, Guarulhos, Itaquaquecetuba, Mogi das Cruzes, Poá, Salesópolis, São Paulo e Suzano;

- Subcomitê Cotia-Guarapiranga: Cotia, Embu das Artes, Embu-Guaçu, Itapecerica da Serra, Juquitiba, São Lourenço da Serra e São Paulo;

- Subcomitê Penha-Pinheiros-Pirapora*: Barueri, Carapicuíba, Jandira, Itapevi, Osasco, Pirapora de Bom Jesus, Santana de Parnaíba, São Paulo e Taboão da Serra;

\footnotetext{
* De acordo com o Relatório I: Plano de Bacia Hidrográfica do Alto Tietê - UGRHI 06 - Ano Base 2016/2035, o subcomitê até então chamado de Pinheiros-Pirapora, passou a ser o Penha-Pinheiros-
} 
- Subcomitê Juqueri-Cantareira: Cajamar, Caieiras, Francisco Morato, Franco da Rocha, Mairiporã e São Paulo; e

- Subcomitê Billings-Tamanduateí: Diadema, Mauá, Ribeirão Pires, Rio Grande da Serra, Santo André, São Bernardo do Campo e São Caetano do Sul e São Paulo.

Figura 5 - Estrutura do Comitê de Bacia Hidrográfica do Alto Tietê.

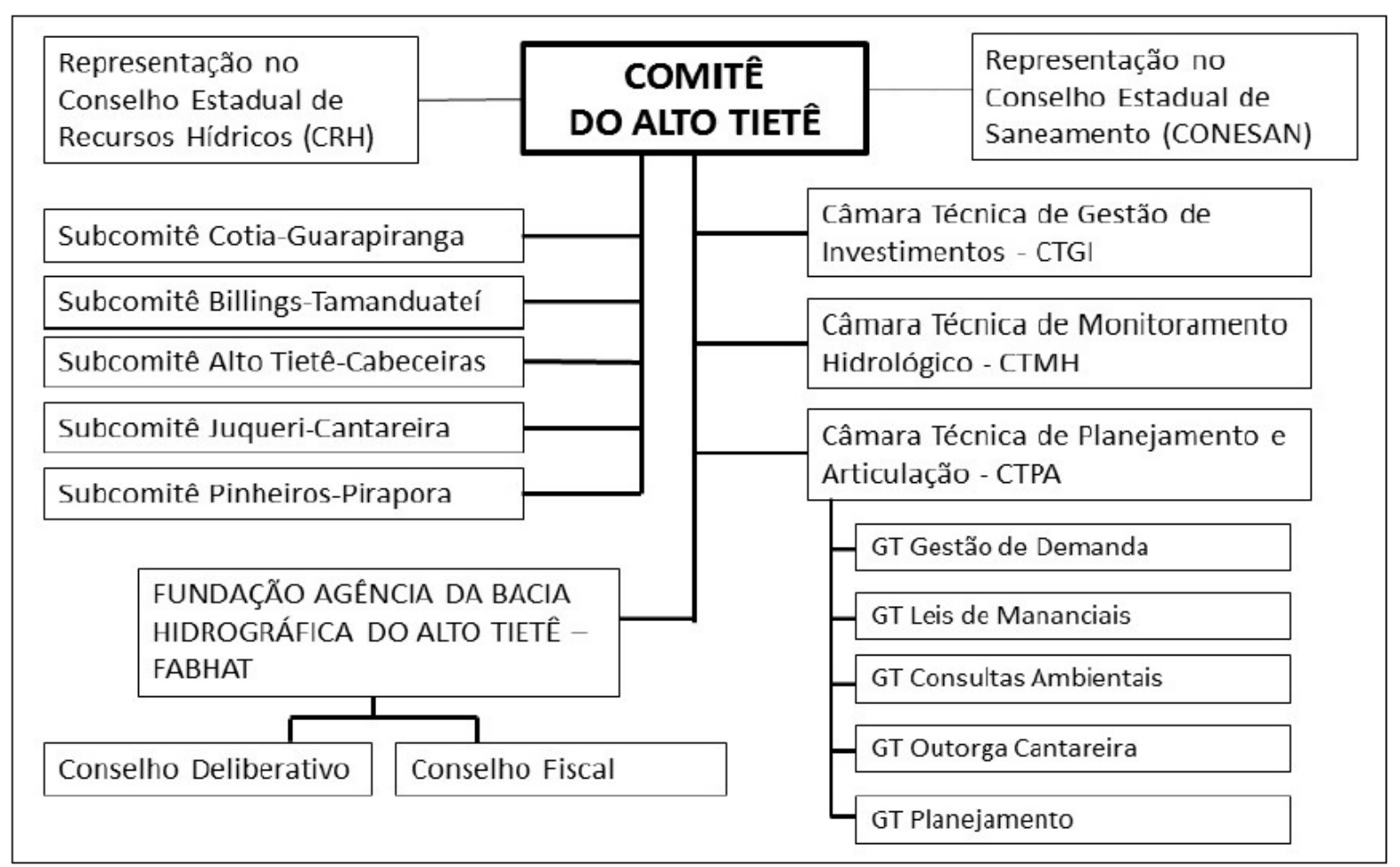

Fonte: CBH-AT, 2016.

As Câmaras Técnicas (CT's) e os Grupos de Trabalho (GT's) foram criados ao longo do tempo de acordo com as necessidades do comitê de discutir temas específicos sem que o mesmo ocupasse muito espaço dentro das reuniões, podendo haver discussão aprofundada sobre os temas e levar ao conhecimento de todos os membros apenas as informações mais importantes. De acordo com o Estatuto do CBH-AT (2015a) (Seção IV - Das Câmaras Técnicas):

Artigo 21 - As Câmaras Técnicas são equipes colegiadas, de caráter consultivo, compostas preferencialmente com representação paritária dos segmentos, por membros titulares ou suplentes do Comitê, ou seus representantes formalmente indicados para essa finalidade,

Pirapora. Portanto, no desenvolvimento do trabalho, será utilizada a definição Pinheiros-Pirapora, quando se tratar dos anos anteriores ao Relatório I. 
encarregadas de examinar, estudar e relatar matérias afetas às respectivas competências.

$(\ldots)$

Artigo 23 - As Câmaras Técnicas poderão criar Grupos de Trabalho, no âmbito de suas atribuições específicas, com objetivo e prazo determinados. 

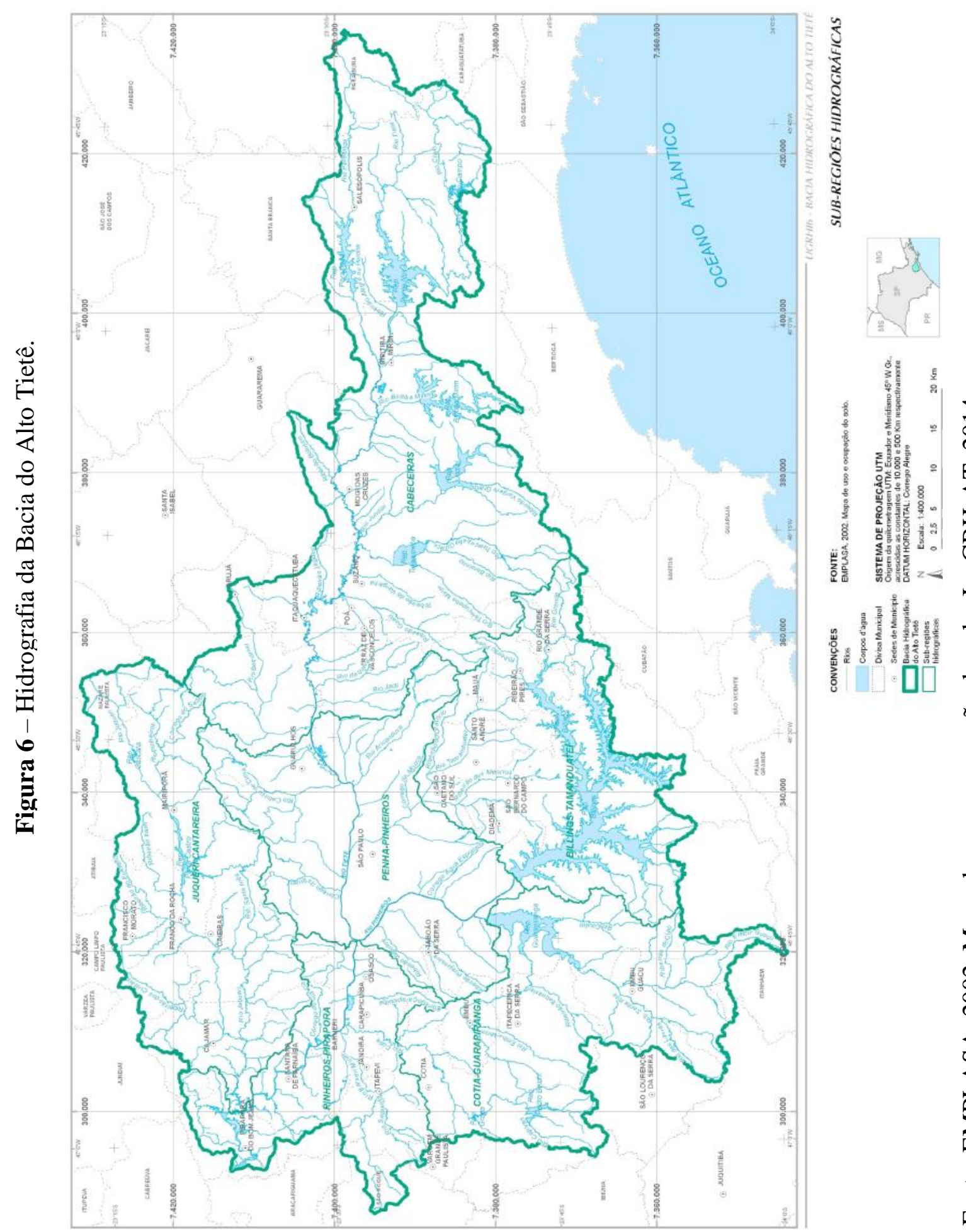

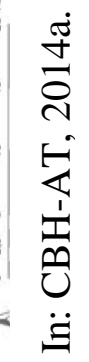

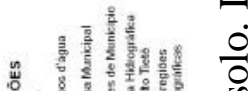

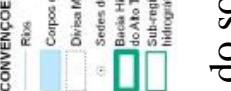

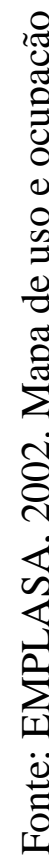




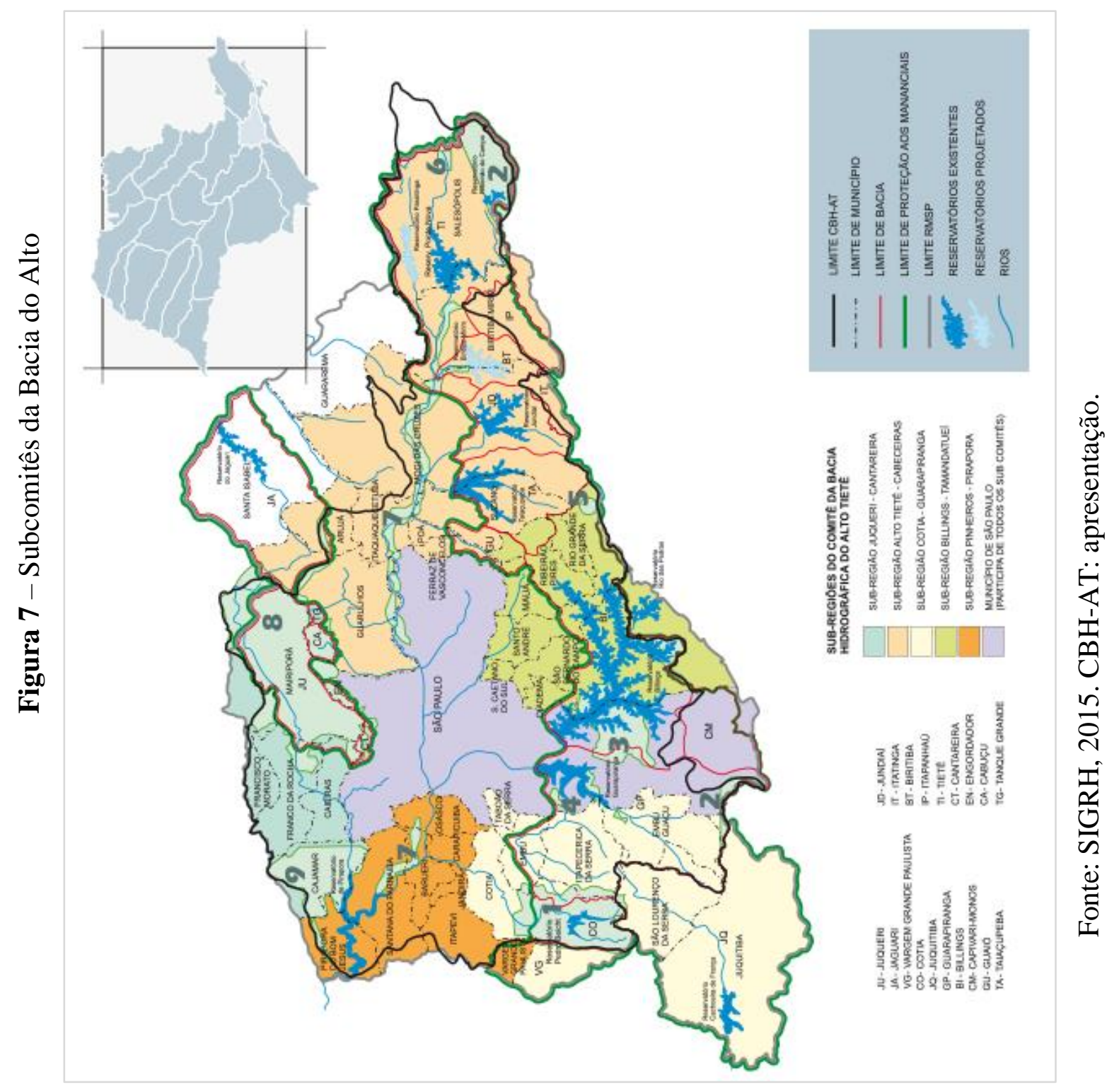




\subsection{ASPECTOS SOCIOECONÔMICOS}

A BH-AT caracteriza-se por estar em quase toda a RMSP, com 34 municípios da região metropolitana presente no $\mathrm{CBH}-\mathrm{AT}$. Como consequência, grande parte da bacia está inserida em área urbanizada e conta com mais de 20 milhões de habitantes, tendo mais de 30 municípios com grau de urbanização acima de $90 \%$ (Quadro 2).

Quadro 2 - Densidade demográfica, população total e grau de urbanização dos municípios da Bacia Hidrográfica do Alto Tietê.

\begin{tabular}{|c|c|c|c|c|c|}
\hline Localidades & $\begin{array}{c}\text { Densidade } \\
\text { Demográfica } \\
\left(\text { Habitantes } / \mathbf{k m}^{2}\right) \\
\end{array}$ & $\begin{array}{c}\text { População } \\
\text { Total }\end{array}$ & $\begin{array}{c}\text { População } \\
\text { Urbana }\end{array}$ & $\begin{array}{c}\text { População } \\
\text { Rural }\end{array}$ & $\begin{array}{c}\text { Grau de } \\
\text { Urbanização } \\
(\%) \\
\end{array}$ \\
\hline Arujá & 871,88 & 83.849 & 80.655 & 3.194 & 96,19 \\
\hline Barueri & 3885,48 & 255.276 & 255.276 & 0 & 100 \\
\hline Biritiba-Mirim & 97,1 & 30.822 & 26.719 & 4.103 & 86,69 \\
\hline Caieiras & 972,9 & 94.994 & 93.114 & 1.880 & 98,02 \\
\hline Cajamar & 550,19 & 72.289 & 71.289 & 1.000 & 98,62 \\
\hline Carapicuíba & 11156,99 & 385.474 & 385.474 & 0 & 100 \\
\hline Cotia & 707,74 & 229.300 & 229.300 & 0 & 100 \\
\hline Diadema & 12934,59 & 397.868 & 397.868 & 0 & 100 \\
\hline Embu das Artes & 3677,8 & 258.917 & 258.917 & 0 & 100 \\
\hline Embu-Guaçu & 423,73 & 65.950 & 64.191 & 1.759 & 97,33 \\
\hline Ferraz de Vasconcelos & 6196,31 & 183.163 & 174.944 & 8.219 & 95,51 \\
\hline Francisco Morato & 3389,33 & 166.077 & 165.739 & 338 & 99,8 \\
\hline Franco da Rocha & 1085,7 & 144.159 & 132.811 & 11.348 & 92,13 \\
\hline Guarulhos & 4081,55 & 1.300 .708 & 1.300 .708 & 0 & 100 \\
\hline Itapecerica da Serra & 1080,72 & 162.907 & 161.557 & 1.350 & 99,17 \\
\hline Itapevi & 2691,76 & 222.501 & 222.501 & 0 & 100 \\
\hline Itaquaquecetuba & 4243,65 & 350.610 & 350.610 & 0 & 100 \\
\hline Jandira & 6734,56 & 117.518 & 117.518 & 0 & 100 \\
\hline Mairiporã & 286,08 & 91.745 & 83.059 & 8.686 & 90,53 \\
\hline Mauá & 7170,25 & 443.910 & 443.910 & 0 & 100 \\
\hline Mogi das Cruzes & 582,57 & 415.107 & 384.031 & 31.076 & 92,51 \\
\hline Osasco & 10385,71 & 674.552 & 674.552 & 0 & 100 \\
\hline Pirapora do Bom Jesus & 161,75 & 17.548 & 17.548 & 0 & 100 \\
\hline Poá & 6484,88 & 111.929 & 110.161 & 1.768 & 98,42 \\
\hline Ribeirão Pires & 1179,6 & 116.875 & 116.875 & 0 & 100 \\
\hline Rio Grande da Serra & 1307,32 & 47.508 & 47.508 & 0 & 100 \\
\hline Salesópolis & 38,46 & 16.346 & 10.672 & 5.674 & 65,29 \\
\hline Santana de Parnaíba & 704,35 & 126.747 & 126.747 & 0 & 100 \\
\hline Santo André & 3909,72 & 687.250 & 687.250 & 0 & 100 \\
\hline
\end{tabular}

Continua 
Quadro 2 - Densidade demográfica, população total e grau de urbanização dos municípios da Bacia Hidrográfica do Alto Tietê.

Continuação

\begin{tabular}{|l|c|c|c|c|c|}
\hline \multicolumn{1}{|c|}{ Localidades } & $\begin{array}{c}\text { Densidade } \\
\text { Demográfica } \\
(\text { Habitantes/km²) }\end{array}$ & $\begin{array}{c}\text { População } \\
\text { Total }\end{array}$ & $\begin{array}{c}\text { População } \\
\text { Urbana }\end{array}$ & $\begin{array}{c}\text { População } \\
\text { Rural }\end{array}$ & $\begin{array}{c}\text { Grau de } \\
\text { Urbanização } \\
(\%)\end{array}$ \\
\hline São Bernardo do Campo & 1942,67 & 795.541 & 782.548 & 12.993 & 98,37 \\
\hline São Caetano do Sul & 9832,49 & 150.732 & 150.732 & 0 & 100 \\
\hline São Paulo & 7651,52 & 11.638 .802 & 11.534 .180 & 104.622 & 99,1 \\
\hline Suzano & 1355,83 & 279.626 & 269.782 & 9.844 & 96,48 \\
\hline Taboão da Serra & 13159,64 & 268.325 & 268.325 & 0 & 100 \\
\hline
\end{tabular}

Fonte: SEADE, 2017.

As taxas de crescimento nas áreas de mananciais estão acima que da média geral da bacia, isto devido à falta de estrutura de gerenciamento destas localidades, colocando em risco a qualidade dos mananciais a médio e longo prazo (CBH-AT, 2016). Sobre este crescimento, o CBH-AT (2002, p. 11) disserta:

A expulsão da população de baixa renda para as zonas periféricas das cidades, (...), agrava a degradação ambiental pela expansão desordenada, pela falta de infraestrutura urbana adequada, gerando os consequentes problemas de ocupação de áreas de proteção a mananciais e das várzeas, além da necessidade de expansão dos sistemas de abastecimento de água e coleta de esgotos sanitários e de coleta de lixo. Isto acarreta uma consequência bastante séria para a região que é a necessidade da continuidade do investimento na expansão da infraestrutura urbana, a taxas superiores às próprias taxas globais de crescimento populacional. Esvazia-se o centro urbano, cuja infraestrutura, já instalada e consolidada, passa a ter ociosidade crescente, e incha-se a periferia, que, penosamente, aguarda o sistema ter possibilidade de aumentar seus investimentos e levar, para aí, a infraestrutura básica necessária.

O processo de urbanização sem a implantação do sistema de coleta, afastamento e tratamento dos esgotos e da coleta de resíduos sólidos também acarreta graves consequências aos corpos d'água superficiais e subterrâneos, afetando a qualidade das águas e tornando-as insalubre para a população.

Segundo dados da Fundação Sistema Estadual de Análise de Dados - SEADE (2017), o Índice Paulista de Responsabilidade Social (IPRS) une informações sobre riqueza, escolaridade e longevidade da população, sendo de grande valor na análise da situação dos 
municípios. Desta forma, o indicador é composto por cinco grupos, os quais possuem as seguintes descrições:

- Grupo 1: municípios que se caracterizam por um nível elevado de riqueza com bons níveis nos indicadores sociais;

- Grupo 2: municípios que, embora com níveis de riqueza elevados, não são capazes de atingir bons indicadores sociais;

- Grupo 3: municípios com nível de riqueza baixo, mas com bons indicadores sociais;

- Grupo 4: municípios que apresentam baixos níveis de riqueza e níveis intermediários de longevidade e/ou escolaridade; e

- Grupo 5: municípios mais desfavorecidos do Estado, tanto em riqueza quanto nos indicadores sociais.

Entre os municípios que compõem a $\mathrm{BH}-\mathrm{AT}, 35 \%$ não possuem bons indicadores de riqueza, escolaridade e longevidade e outros $50 \%$ apesar da riqueza, não possuem bons indicadores sociais, evidenciando que apesar do potencial econômico, há ainda fragilidade social na região (Gráfico 3). Este potencial econômico é evidenciado pelos índices econômicos. Em 2015, a RMSP teve 31,8\% de participação nas exportações do Estado e 55\% de participação no PIB do Estado (SEADE, 2017).

Gráfico 4 - Porcentagem de municípios por grupo do IPRS - ano base 2012.

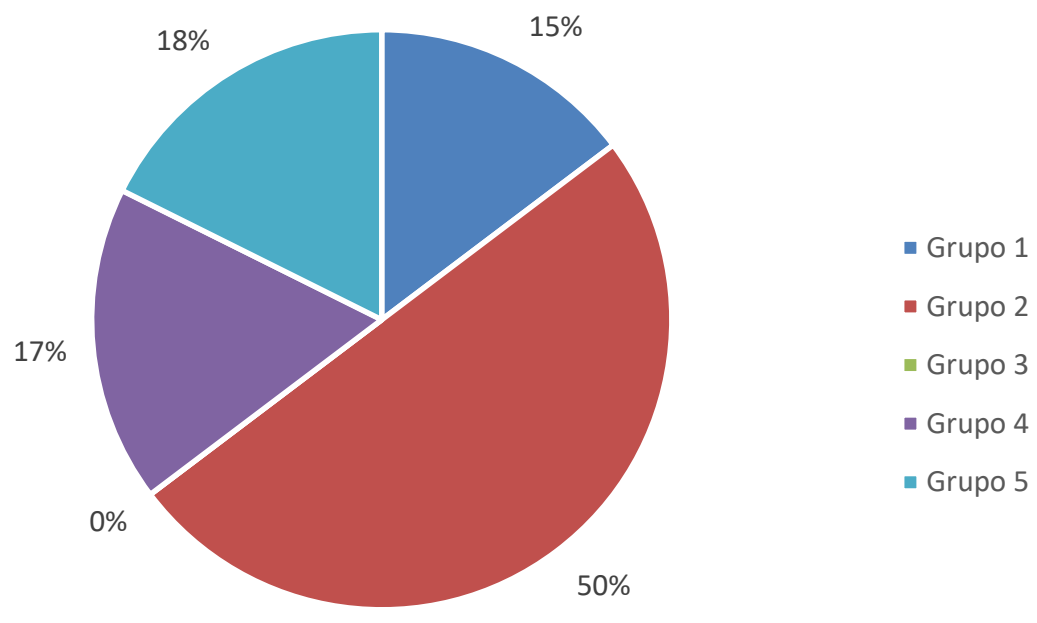

Fonte: Dados do SEADE, 2017. Elaborado pela autora. 


\subsection{SANEAMENTO BÁSICO}

De acordo com a Lei Federal n ${ }^{\circ} 11.445$, de 5 de janeiro de 2007, saneamento básico é o conjunto de serviços, infraestruturas e instalações operacionais que abarcam o abastecimento de água potável, o esgotamento sanitário, a limpeza urbana e manejo de resíduos sólidos, e a drenagem e manejo de águas pluviais. A lei prevê que os responsáveis pelos serviços descritos anteriormente, devam elaborar os planos de saneamento básico de acordo com os termos estabelecidos na legislação. O quesito resíduos sólidos ainda conta com a Lei Federal $\mathrm{n}^{\circ}$ 12.305, de 2 de agosto de 2010, que institui princípios, objetivos e instrumentos de gestão.

Em 2016, o CBH-AT realizou pesquisa via questionário com os trinta e quatro municípios da BH-AT. Vinte e sete municípios enviaram suas respostas, contatando-se que apenas dez possuíam Plano de Saneamento elaborado e instituído ou Lei Municipal, nove estavam em fase de elaboração e/ou de audiência pública e oito possuíam pelo menos o plano de um dos componentes do saneamento (Quadro 3):

Quadro 3 - Situação dos Planos de Saneamento nos municípios da Bacia Hidrográfica do Alto Tietê.

\begin{tabular}{|c|c|c|c|c|}
\hline \multirow[b]{2}{*}{ Municípios } & \multicolumn{4}{|c|}{ Situação dos Planos Municipais de Saneamento } \\
\hline & $\begin{array}{l}\text { Abastecimento de } \\
\text { água }\end{array}$ & $\begin{array}{l}\text { Esgotamento } \\
\text { sanitário }\end{array}$ & $\begin{array}{c}\text { Manejo de } \\
\text { resíduos sólidos }\end{array}$ & $\begin{array}{l}\text { Drenagem de } \\
\text { águas pluviais }\end{array}$ \\
\hline Arujá & $\begin{array}{lr}\text { Elaborado } & \mathrm{e} \\
\text { instituído pela } & \text { Lei } \\
\text { Municipal } & \mathrm{n}^{\mathbf{0}} \\
2410 / 2011 & \\
\end{array}$ & $\begin{array}{lr}\text { Elaborado } & \mathrm{e} \\
\text { instituído pela Lei } \\
\text { Municipal } \\
2410 / 2011\end{array}$ & $\begin{array}{lr}\text { Elaborado } & \mathrm{e} \\
\text { instituído pela } & \text { Lei } \\
\text { Municipal } & \mathrm{n}^{\mathbf{0}} \\
2410 / 2011 & \\
\end{array}$ & $\begin{array}{lr}\text { Elaborado } & \mathrm{e} \\
\text { instituído pela } & \text { Lei } \\
\text { Municipal } & \mathrm{n}^{\mathbf{o}} \\
2410 / 2011 & \\
\end{array}$ \\
\hline Barueri & $\begin{array}{l}\text { Elaborado } \\
\text { instituído pela Lei } \\
\text { Municipal } \\
2.247 / 2013\end{array}$ & $\begin{array}{l}\text { Elaborado e } \\
\text { instituído pela Lei } \\
\text { Municipal } \\
2.247 / 2013\end{array}$ & $\begin{array}{l}\text { Plano Municipal de } \\
\text { Gestão Integrada de } \\
\text { Resíduos } \\
\text { aprólidos } \\
\text { Decreto Municipal } \\
6.833 / 2010\end{array}$ & $\begin{array}{l}\text { Plano Municipal de } \\
\text { Drenagem } \\
\text { aprovado pelo } \\
\text { Decreto Municipal } \\
7.743 / 2013\end{array}$ \\
\hline Biritiba Mirim & * & $*$ & $*$ & $*$ \\
\hline Caieiras & $\begin{array}{l}\text { Elaborado } r \\
\text { instituído pela Lei } \\
\mathrm{n}^{\circ} \text { Municipal } \\
4795 / 2015\end{array}$ & $\begin{array}{l}\text { Elaborado e } \\
\text { instituído pela Lei } \\
\mathrm{n}^{\circ} \quad \text { Municipal } \\
4795 / 2015\end{array}$ & $\begin{array}{l}\text { Elaborado } \\
\text { instituído pela Lei } \\
\mathrm{n}^{\circ} \text { Municipal } \\
4796 / 2015\end{array}$ & $\begin{array}{l}\text { Elaborado } \\
\text { instituído pela Lei } \\
\mathrm{n}^{\circ} \text { Municipal } \\
4795 / 2015\end{array}$ \\
\hline Cajamar & $\begin{array}{l}\text { Elaborado } \\
\text { instituído pela Lei } \\
\text { n. }^{\circ} 1.459 / 2011\end{array}$ & $\begin{array}{l}\text { Elaborado e } \\
\text { instituído pela Lei } \\
\text { n. }{ }^{\circ} 1.459 / 2011\end{array}$ & $\begin{array}{lr}\text { Elaborado } & \mathrm{e} \\
\text { instituído pela Lei } \\
\text { n. }^{\circ} 1.459 / 2011\end{array}$ & $\begin{array}{l}\text { Elaborado } \\
\text { instituído pela Lei } \\
\text { n. }^{\circ} 1.459 / 2011\end{array}$ \\
\hline Carapicuíba & $\begin{array}{l}\text { Em fase de } \\
\text { elaboração }\end{array}$ & $\begin{array}{l}\text { Em fase de } \\
\text { elaboração }\end{array}$ & $\begin{array}{l}\text { Em fase de } \\
\text { elaboração }\end{array}$ & $\begin{array}{l}\text { Em fase de } \\
\text { elaboração }\end{array}$ \\
\hline Cotia & $*$ & $*$ & Em elaboração & $*$ \\
\hline Diadema & $\begin{array}{l}\text { Elaborado, em fase } \\
\text { de preparação do } \\
\text { Projeto de Lei }\end{array}$ & $\begin{array}{lr}\text { Elaborado, } & \text { em } \\
\text { fase } & \text { de } \\
\text { preparação } & \text { do } \\
\text { Projeto de Lei } & \end{array}$ & $\begin{array}{l}\text { Elaborado, em fase } \\
\text { de preparação do } \\
\text { Projeto de Lei }\end{array}$ & $\begin{array}{l}\text { Elaborado, em fase } \\
\text { de preparação do } \\
\text { Projeto de Lei }\end{array}$ \\
\hline
\end{tabular}

Continua 
Quadro 3 - Situação dos Planos de Saneamento nos municípios da BH-AT.

Continuação

\begin{tabular}{|c|c|c|c|c|}
\hline \multirow[b]{2}{*}{ Municípios } & \multicolumn{4}{|c|}{ Situação dos Planos Municipais de Saneamento } \\
\hline & $\begin{array}{c}\text { Abastecimento de } \\
\text { água }\end{array}$ & $\begin{array}{l}\text { Esgotamento } \\
\text { sanitário }\end{array}$ & $\begin{array}{c}\text { Manejo de } \\
\text { resíduos sólidos }\end{array}$ & $\begin{array}{l}\text { Drenagem de } \\
\text { águas pluviais }\end{array}$ \\
\hline Embu das Artes & $\begin{array}{lr}\text { Elaborado } & \text { e } \\
\text { instituído pela } & \text { Lei } \\
\text { Municipal } & n^{\circ} \\
162 / 2011 & \\
\end{array}$ & $\begin{array}{lr}\text { Elaborado } & \mathrm{e} \\
\text { instituído pela Lei } \\
\text { Municipal } \\
162 / 2011\end{array}$ & $\begin{array}{lr}\text { Elaborado } & \text { e } \\
\text { instituído pela } & \text { Lei } \\
\text { Municipal } & n^{\circ} \\
162 / 2011 & \\
\end{array}$ & $\begin{array}{lr}\text { Elaborado } & \mathrm{e} \\
\text { instituído pela } & \text { Lei } \\
\text { Municipal } & \mathrm{n}^{\circ} \\
162 / 2011 & \\
\end{array}$ \\
\hline Embu-Guaçu & 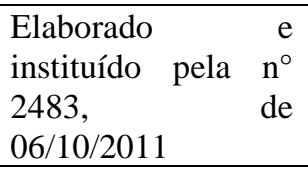 & $\begin{array}{lr}\text { Elaborado } & \text { e } \\
\text { instituído pela } & \mathrm{n}^{\circ} \\
2483, & \mathrm{de} \\
06 / 10 / 2011 & \end{array}$ & $\begin{array}{ll}\text { Elaborado } & \text { e } \\
\text { instituído pela } & n^{\circ} \\
2483, & \\
06 / 10 / 2011 & \end{array}$ & $\begin{array}{llr}\text { Elaborado } & & \mathrm{e} \\
\text { instituído pela } & \mathrm{n}^{\circ} \\
2483, & & \mathrm{de} \\
06 / 10 / 2011 & \end{array}$ \\
\hline $\begin{array}{l}\text { Ferraz de } \\
\text { Vasconcelos }\end{array}$ & $\begin{array}{l}\text { Em fase de } \\
\text { elaboração }\end{array}$ & $\begin{array}{l}\text { Em fase de } \\
\text { elaboração }\end{array}$ & $\begin{array}{l}\text { Em fase de } \\
\text { elaboração }\end{array}$ & $\begin{array}{l}\text { Em fase } \\
\text { elaboração }\end{array}$ \\
\hline Francisco Morato & $\begin{array}{l}\text { Elaborado } \\
\text { instituído pela Lei } \\
\text { Complementar n. }^{\text {o }} \\
\text { 020, de } 13 / 09 / 2010 .\end{array}$ & $\begin{array}{l}\text { Elaborado e } \\
\text { instituído pela Lei } \\
\text { Complementar }^{\text {. }}{ }^{\text {e }} \\
020, \\
13 / 09 / 2010 .\end{array}$ & $\begin{array}{l}\text { Em fase } \\
\text { elaboração }\end{array}$ & Não possui \\
\hline Franco da Rocha & $\begin{array}{lr}\text { Elaborado } & \mathrm{e} \\
\text { instituído pela } & \text { Lei } \\
\text { Decreto } & \mathrm{N}^{\mathrm{o}} \\
2.003 / 2012 & \\
\end{array}$ & $\begin{array}{lr}\text { Elaborado } & \mathrm{e} \\
\text { instituído pela Lei } \\
\text { Decreto } & \mathrm{N}^{\mathrm{o}} \\
2.003 / 2012 & \\
\end{array}$ & $\begin{array}{lr}\text { Elaborado } & \mathrm{e} \\
\text { instituído pela } & \text { Lei } \\
\text { Decreto } & \mathrm{N}^{\mathrm{o}} \\
2.003 / 2012 & \\
\end{array}$ & $\begin{array}{lr}\text { Elaborado } & \mathrm{e} \\
\text { instituído pela } & \text { Lei } \\
\text { Decreto } & \mathrm{N}^{\mathrm{o}} \\
2.003 / 2012 & \\
\end{array}$ \\
\hline Guar & $\begin{array}{l}\text { Elaborado } \\
\text { instituído pelo } \\
\text { Decreto Municipal } \\
\mathrm{n}^{\circ} 30.840 / 2013\end{array}$ & $\begin{array}{lr}\text { Elaborado } & \mathrm{e} \\
\text { instituído } & \text { pelo } \\
\text { Decreto } & \\
\text { Municipal } & \mathrm{n}^{\circ} \\
30.840 / 2013 & \\
\end{array}$ & $\begin{array}{l}\text { Elaborado } \\
\text { instituído pelo } \\
\text { Decreto Municipal } \\
\mathrm{n}^{\circ} 30.840 / 2013\end{array}$ & $\begin{array}{l}\text { Elaborado } \\
\text { instituído pelo } \\
\text { Decreto Municipal } \\
\mathrm{n}^{\circ} 30.840 / 2013\end{array}$ \\
\hline Itapec & $\begin{array}{l}\text { Elaborado } \\
\text { instituído pela Lei } \\
\text { Complementar n. } \\
\text { 020, de 13/09/2010. }\end{array}$ & $\begin{array}{l}\text { Elaborado } r \\
\text { instituído pela Lei } \\
\text { Complementar } \text { n. }^{\text {o }} \\
020, \\
13 / 09 / 2010 .\end{array}$ & $\begin{array}{l}\text { Em fase } \\
\text { elaboração }\end{array}$ & Não 1 \\
\hline Itapevi & $\begin{array}{lr}\text { Elaborado } & \mathrm{e} \\
\text { instituído pela } & \text { Lei } \\
\text { Complementar } & \mathrm{N}^{\mathrm{o}} \\
62 / 2012 \text { e } & \text { Lei } \\
\text { Complementar } & \mathrm{N}^{\mathrm{O}} \\
65 / 2013 & \\
\end{array}$ & $\begin{array}{l}\text { Elaborado e } \\
\text { instituído pela Lei } \\
\text { Complementar } \mathrm{N}^{\mathrm{o}} \\
62 / 2012 \text { e Lei } \\
\text { Complementar } \mathrm{N}^{\circ} \\
65 / 2013\end{array}$ & $\begin{array}{l}\text { Lei Complementar } \\
\mathrm{N}^{\circ} 62 / 2012 \\
\text { Lei complementar } \\
\mathrm{N}^{\circ} 65 / 2013 \\
\text { Lei } \mathrm{N}^{\circ} 2261 / 2014\end{array}$ & Não possui \\
\hline Itaq & $\begin{array}{l}\text { Elaborado } \\
\text { instituído pela Lei } \\
3.102 / 2013\end{array}$ & $\begin{array}{l}\text { Elaborado e } \\
\text { instituído pela Lei } \\
3.102 / 2013\end{array}$ & $\begin{array}{l}\text { Elaborado } \\
\text { instituído pela Lei } \\
3.102 / 2013\end{array}$ & $\begin{array}{l}\text { Elaborado } \\
\text { instituído pela Lei } \\
3.102 / 2013\end{array}$ \\
\hline Jandira & $\begin{array}{l}\text { Elaborado, em fase } \\
\text { de audiência } \\
\text { pública }\end{array}$ & $\begin{array}{l}\text { Elaborado, em } \\
\text { fase de audiência } \\
\text { pública }\end{array}$ & $\begin{array}{l}\text { Elaborado, em fase } \\
\text { de audiência } \\
\text { pública }\end{array}$ & $\begin{array}{l}\text { Elaborado, em fase } \\
\text { de audiência } \\
\text { pública }\end{array}$ \\
\hline Mairiporã & $\begin{array}{l}\text { Elaborado } \\
\text { instituído pela Lei } \\
\text { Municipal } \\
3.312 / 2013\end{array}$ & $\begin{array}{l}\text { Elaborado e } \\
\text { instituído pela Lei } \\
\text { Municipal } \\
3.312 / 2013\end{array}$ & $\begin{array}{l}\text { Elaborado } \\
\text { instituído pela Lei } \\
\text { Municipal } \\
3.312 / 2013\end{array}$ & $\begin{array}{l}\text { Elaborado } \\
\text { instituído pela Lei } \\
\text { Municipal } \\
3.312 / 2013\end{array}$ \\
\hline Mauá & $\begin{array}{l}\text { Elaborado } \\
\text { instituído pela Lei } \\
4.901 / 2013\end{array}$ & $\begin{array}{l}\text { Elaborado e } \\
\text { instituído pela Lei } \\
4.901 / 2013\end{array}$ & $\begin{array}{l}\text { Elaborado } \\
\text { instituído pela Lei } \\
4.901 / 2013\end{array}$ & $\begin{array}{l}\text { Elaborado } \\
\text { instituído pela Lei } \\
4.901 / 2013\end{array}$ \\
\hline Mog & & $*$ & & \\
\hline
\end{tabular}


Quadro 3 - Situação dos Planos de Saneamento nos municípios da BH-AT.

Continuação

\begin{tabular}{|c|c|c|c|c|}
\hline \multirow[b]{2}{*}{ Municípios } & \multicolumn{4}{|c|}{ Situação dos Planos Municipais de Saneamento } \\
\hline & $\begin{array}{c}\text { Abastecimento de } \\
\text { água }\end{array}$ & $\begin{array}{l}\text { Esgotamento } \\
\text { sanitário }\end{array}$ & $\begin{array}{c}\text { Manejo de } \\
\text { resíduos sólidos }\end{array}$ & $\begin{array}{l}\text { Drenagem de } \\
\text { águas pluviais }\end{array}$ \\
\hline Osasco & $\begin{array}{l}\text { Em fase } \\
\text { Elaboração }\end{array}$ & $\begin{array}{l}\text { Em fase } \\
\text { Elaboração }\end{array}$ & $\begin{array}{lr}\text { Elaborado } & \mathrm{e} \\
\text { instituído } & \text { pelo } \\
\text { Decreto } & \text { n. } \\
9.758 / 2007 & \\
\end{array}$ & $\begin{array}{l}\text { Em fase } \\
\text { Elaboração }\end{array}$ \\
\hline $\begin{array}{l}\text { Pirapc } \\
\text { Jesus }\end{array}$ & $*$ & $*$ & $*$ & $*$ \\
\hline Poá & $\begin{array}{lll}\text { Lei Municipal } & \mathrm{n}^{\mathrm{o}} \\
3.601 / 2013 & \\
\end{array}$ & $\begin{array}{l}\text { Lei Municipal } n^{\circ} \\
\text { 3. } 601 / 2013\end{array}$ & $\begin{array}{ll}\text { Lei Municipal } & n^{\circ} \\
3.601 / 2013 & \\
\end{array}$ & $\begin{array}{l}\text { Lei Municipal } \mathrm{n}^{\mathrm{o}} \\
3.601 / 2013\end{array}$ \\
\hline Ribeirão Pires & $\begin{array}{l}\text { Elaborado } \\
\text { instituído pela Lei } \\
\text { n. }{ }^{\circ} 5.485 / 2010\end{array}$ & $\begin{array}{l}\text { Elaborado e } \\
\text { instituído pela Lei } \\
\text { n. }{ }^{\circ} 5.485 / 2010\end{array}$ & $\begin{array}{lr}\text { Elaborado } & \mathrm{e} \\
\text { instituído pela } & \text { Lei } \\
\text { Municipal } & \mathrm{n}^{\mathbf{o}} \\
5.654 / 2012 & \end{array}$ & Não possui \\
\hline $\begin{array}{l}\text { Rio G } \\
\text { Serra }\end{array}$ & Elaborado & Elaborado & Não possui & Elaborado \\
\hline Salesó & $\begin{array}{l}\text { Elaborado, em fase } \\
\text { de audiência } \\
\text { pública }\end{array}$ & $\begin{array}{l}\text { Elaborado, em } \\
\text { fase de audiência } \\
\text { pública }\end{array}$ & $\begin{array}{l}\text { Em elaboração com } \\
\text { recurso do } \\
\text { FEHIDRO }\end{array}$ & $\begin{array}{l}\text { Em elaboração com } \\
\text { recurso do } \\
\text { FEHIDRO }\end{array}$ \\
\hline Santana de Parnaíba & $\begin{array}{lr}\begin{array}{l}\text { Elaborado } \\
\text { instituído pela }\end{array} & \text { Lei } \\
\text { Municipal } & \mathrm{n}^{\mathbf{0}} \\
3.414 / 2014 & \end{array}$ & $\begin{array}{lr}\text { Elaborado } & \text { e } \\
\text { instituído pela Lei } \\
\text { Municipal } \\
3.414 / 2014\end{array}$ & $\begin{array}{lr}\text { Elaborado } & \text { e } \\
\text { instituído pela } & \text { Lei } \\
\text { Municipal } & n^{\text {o }} \\
3.414 / 2014 & \end{array}$ & $\begin{array}{lr}\text { Elaborado } & \mathrm{e} \\
\text { instituído pela } & \text { Lei } \\
\text { Municipal } & \mathrm{n}^{\circ} \\
3.414 / 2014 & \end{array}$ \\
\hline Santo André & $\begin{array}{lr}\text { Elaborado } & \text { e } \\
\text { instituído pela } & \text { Lei } \\
\text { Decreto } & \\
\mathrm{n}^{\circ} 16.586 / 2014 & \\
\end{array}$ & $\begin{array}{l}\text { Elaborado e } \\
\text { instituído pela Lei } \\
\text { Decreto } \\
\mathrm{n}^{\circ} 16.586 / 2014\end{array}$ & $\begin{array}{lr}\text { Elaborado } & \mathrm{e} \\
\text { instituído } & \text { pelo } \\
\text { Decreto } & \mathrm{n}^{\mathrm{o}} \\
16.310 / 2012 . & \\
\end{array}$ & $\begin{array}{lr}\text { Elaborado } & \mathrm{e} \\
\text { instituído } & \text { pelo } \\
\text { Decreto } & \mathrm{n}^{\circ} \\
16.310 / 2012 . & \\
\end{array}$ \\
\hline $\begin{array}{l}\text { São Bern } \\
\text { Campo }\end{array}$ & * & * & $*$ & $*$ \\
\hline São Caetano do Sul & $\begin{array}{lr}\text { Elaborado } & \mathrm{e} \\
\text { instituído } & \text { pelo } \\
\text { Decreto } & \text { n. }^{\text {o }} \\
10.042 / 2010 & \\
\end{array}$ & $\begin{array}{lr}\text { Elaborado } & \mathrm{e} \\
\text { instituído } & \text { pelo } \\
\text { Decreto } & \text { n. }^{\text {o }} \\
10.042 / 2010 & \\
\end{array}$ & $\begin{array}{lr}\text { Elaborado } & \mathrm{e} \\
\text { instituído pela } & \text { Lei } \\
\text { Municipal } & \mathrm{n}^{\mathbf{0}} \\
5.162 / 2013 & \\
\end{array}$ & $\begin{array}{l}\text { Em fase } \\
\text { Elaboração }\end{array}$ \\
\hline São Paulo & $\begin{array}{lr}\text { Elaborado } & \mathrm{e} \\
\text { instituído pela } & \text { Lei } \\
\text { Municipal } & \mathrm{n}^{\mathbf{0}} \\
14.934 / 2009 & \\
\end{array}$ & $\begin{array}{lr}\text { Elaborado } & \mathrm{e} \\
\text { instituído pela } & \text { Lei } \\
\text { Municipal } & \mathrm{n}^{\mathrm{o}} \\
14.934 / 2009 & \\
\end{array}$ & $\begin{array}{lr}\text { Elaborado } & \mathrm{e} \\
\text { instituído pela } & \text { Lei } \\
\text { Municipal } & \mathrm{n}^{\mathbf{0}} \\
14.934 / 2009 & \\
\end{array}$ & $\begin{array}{lr}\text { Elaborado } & \mathrm{e} \\
\text { instituído pela } & \text { Lei } \\
\text { Municipal } & \mathrm{n}^{\circ} \\
14.934 / 2009 & \\
\end{array}$ \\
\hline Suzano & $\begin{array}{l}\text { Em fase } \\
\text { Elaboração }\end{array}$ & $\begin{array}{l}\text { Em fase } \\
\text { Elaboração }\end{array}$ & $\begin{array}{l}\text { Em fase de } \\
\text { Elaboração }\end{array}$ & $\begin{array}{l}\text { Em fase de } \\
\text { Elaboração }\end{array}$ \\
\hline Taboão d & $\begin{array}{l}\text { Em fase } \\
\text { Elaboração }\end{array}$ & $\begin{array}{l}\text { Em fase } \\
\text { Elaboração }\end{array}$ & $\begin{array}{l}\text { Em fase } \\
\text { Elaboração }\end{array}$ & $\begin{array}{l}\text { Em fase } \\
\text { Elaboração }\end{array}$ \\
\hline
\end{tabular}

Fonte: CBH-AT, 2016.

Nota:

* Municípios que não haviam respondido o Formulário de Coleta de Dados até a elaboração do Relatório I - Plano de Bacia Hidrográfica do Alto Tietê. Ano base 2016/2035. 


\subsubsection{ABASTECIMENTO DE ÁGUA}

A maior parte do abastecimento da RMSP é feito pela SABESP. Segundo o Relatório da Administração 2016 (SABESP, 2017, p. F-12), a empresa "é uma sociedade anônima de capital aberto e economia mista", detendo o Governo do Estado de São Paulo 50,3\% do capital social, sendo os outros 49,7\% negociados em bolsas de valores no Brasil e no exterior, estando 30,3\% em São Paulo e 19,4\% em Nova Iorque, no dia 31 de dezembro de 2016. No mesmo ano, a receita líquida da empresa foi de aproximadamente $\mathrm{R} \$ 14,1$ bilhões e um lucro de R $\$ 2,9$ bilhões (SABESP, 2017).

A empresa compõe uma rede de trinta municípios no Sistema Integrado Metropolitano (SIM). Cinco desses municípios não são atendidos diretamente pela SABESP, as redes de distribuição são operadas pela municipalidade que compra a água da SABESP, sendo eles: Guarulhos, Mauá, Mogi das Cruzes, Santo André e São Caetano do Sul. O SIM é composto por nove sistemas produtores de água (CETESB, 2016a; SABESP, 2015a; CBH-AT, 2016):

- Alto Tietê: sistema opera desde 1992, representando $17,4 \%$ da produção disponibilizada para a RMSP no ano 2013. As principais represas utilizadas pelo sistema são Biritiba-Mirim, Jundiaí. Paraitinga, Ponte Nova e Taiaçupeba. Além do abastecimento público, a água do Sistema Alto Tietê é utilizada para controle de cheias, regularização de vazões, uso industrial e para irrigação. A água é destinada à zona leste da capital e aos municípios de Arujá, Ferraz de Vasconcelos, Itaquaquecetuba, Mogi das Cruzes, Poá e Suzano.

- Alto e Baixo Cotia: compostos pelas represas Pedro Beicht, Cachoeira da Graça (Alto Cotia) e Isolinas Superior e Inferior (Baixo Cotia), os sistemas atendem Barueri, Jandira, Itapevi, Vargem Grande Paulista e parte do município de Cotia, tendo uma capacidade de produção de $2,30 \mathrm{~m}^{3} / \mathrm{s}\left(1,25 \mathrm{~m}^{3} / \mathrm{s}\right.$ e $1,05 \mathrm{~m}^{3} / \mathrm{s}$, respectivamente).

- Cantareira: operando desde o ano 1974, os principais mananciais do sistema são as represas: Águas Claras, Atibainha, Cachoeira, Jaquari/Jacareí e Paiva Castro, sendo ele o principal sistema de abastecimento da RMSP, produzindo $47 \%$ da água para abastecimento de 2013 da RMSP, suprindo 65\% da demanda do município de São Paulo, abrangendo as zonas norte e central.

- Capivari: suas águas são destinadas à represa Guarapiranga desde 2013, produzindo $0,09 \mathrm{~m} 3 / \mathrm{s}(0,10 \%)$ de água.

- Guarapiranga-Billings: este sistema representa mais de 19,8\% do abastecimento, passando recentemente a produzir de $14 \mathrm{~m}^{3} / \mathrm{s}$ para $16 \mathrm{~m}^{3} / \mathrm{s}$ de água, não é utilizado apenas para este fim, mas também para geração de energia e controle de cheias. Suas principais represas são Guarapiranga e Billings (Taquacetuba) e Rio Capivari.

- Ribeirão Estiva: este sistema opera desde os anos 1960, atendendo somente o abastecimento público do município de Rio Grande da Serra, representando 0,10\% do abastecimento da RMSP.

- Rio Claro: o sistema conta com a represa do Ribeirão do Campo e produz 4,0 m³ $/ \mathrm{s} \mathrm{de}$ água, abastecendo Mauá, Ribeirão Pires e parte dos municípios de Santo André, São Caetano do Sul e da zona leste de São Paulo. 
- Rio Grande: produzindo 5,5 m³/s de água e abastecendo São Bernardo do Campo, Diadema e parte de Santo André e Ribeirão Pires, o sistema é um braço da represa Billings.

Entre os anos 2013 e 2014, em decorrência de alterações no regime de chuvas, todos os sistemas produtores estiveram com seus afluentes abaixo das médias. O Sistema Cantareira, o mais importante da RMSP, produziu menos da metade da vazão média entre os meses de fevereiro de 2014 a janeiro de 2015 (SABESP, 2015b).

Diante da crise hídrica, foram adotados mecanismos de redução de consumo como o Programa de Incentivo à Redução de Consumo de Água. No primeiro ano o programa disponibilizou bônus de $30 \%$ nos valores cobrados de água e esgoto para os consumidores que reduzissem 20\% do consumo em relação ao ano anterior. Após um ano, havendo a necessidade de reduzir mais o consumo e verificando que haviam consumidores que não haviam reduzido o consumo, estabeleceu-se uma tarifa cobrada aos consumidores que ultrapassassem o consumo médio do ano anterior. Outros mecanismos utilizados foram: transferência de água de outros Sistemas Produtores, acarretando em obras emergenciais de ampliação de Estações de Tratamento de Esgoto e adequações em sistemas existentes para ampliar a capacidade; intensificação no Programa de Combate às Perdas; utilização de Reservas Técnicas; campanhas de redução a partir de mídias, palestras e treinamentos; entre outras atividades institucionais (SABESP, 2015b).

Em março de 2015, havia ocorrido redução de 56\% da utilização do reservatório Cantareira (SABESP, 2015b). Segundo CBH-AT (2016), dentro da BH-AT foi alcançado o atendimento de mais de $98 \%$ à população de abastecimento de água, entre os anos 2010 a 2014.

De acordo com o Relatório da Administração 2016, em decorrência da crise hídrica, ocorreram investimentos de $\mathrm{R} \$ 555$ milhões para realizar a interligação das represas Jaguarí Atibainha, conectando a bacia do Paraíba do Sul ao Sistema Cantareira, estando prevista para entrar em operação no segundo semestre de 2017. Outra ação citada foram os investimentos de R \$ 410 milhões no Programa Metropolitano de Água, o qual foi iniciado nos anos 1990 e visa melhorar o atendimento no abastecimento do SIM (SABESP, 2017).

Já o Programa Mananciais, realizado em parceria com a prefeitura do município de São Paulo, desde 2009, que visa a recuperação dos mananciais Billings e Guarapiranga, recebeu o montante de R \$ 39 milhões destinados à ampliação "da infraestrutura de coleta de esgoto" e melhoramento em "loteamentos precários e conjuntos habitacionais instalados em áreas das sub-bacias dos dois mananciais" (SABESP, 2017, p. F-26). 


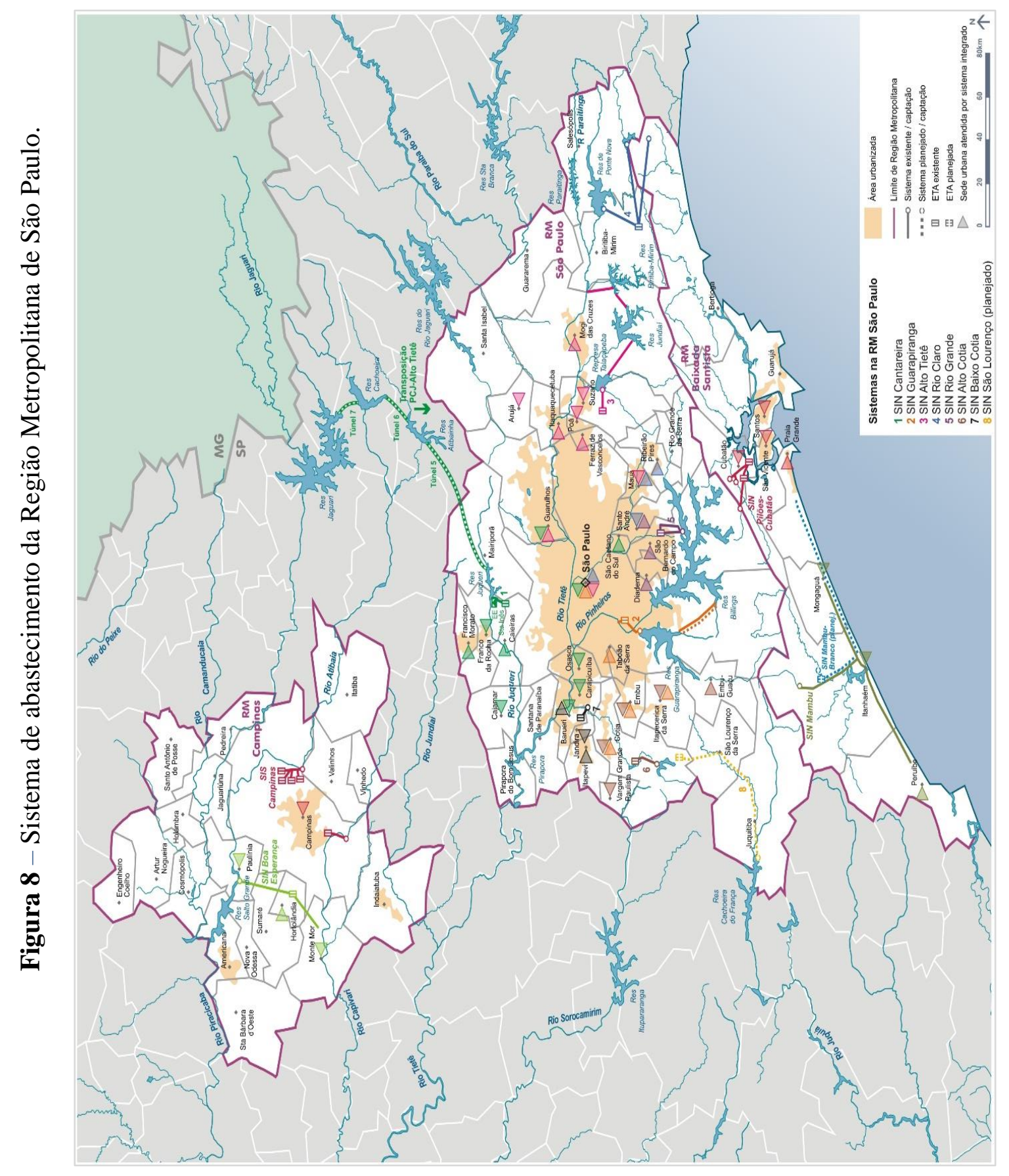

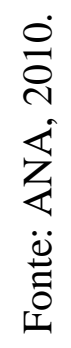




\subsubsection{COLETA E TRATAMENTO DE ESGOTO}

Como ocorre com o abastecimento de água, a SABESP é a responsável pela coleta e tratamento do esgoto na RMSP, não operando apenas os sistemas de esgotamento sanitário dos municípios: Guarulhos, Mauá, Mogi das Cruzes, Santo André e São Caetano do Sul (Tabela 3). A rede é dividida em dois sistemas, um operando na região central - Sistema Principal e outros nas regiões periféricas que são chamados de Sistemas Isolados (CBH-AT, 2014b), como mostra a Figura 9.

Tabela 3 - Percentual de coleta e tratamento de esgoto nos municípios que operam seus sistemas de esgotamento sanitário, em 2015.

\begin{tabular}{cccc}
\hline Município & Coleta de esgoto $(\%)$ & $\begin{array}{c}\text { Tratamento de } \\
\text { esgoto coletado }(\%)\end{array}$ & $\begin{array}{c}\text { Tratamento de } \\
\text { esgoto gerado }(\%)\end{array}$ \\
\hline Guarulhos & 61,64 & $6,2^{* *}$ & $3,8^{* *}$ \\
Mauá & $*$ & $*$ & $*$ \\
Mogi das Cruzes & 73,31 & 83,12 & 60,93 \\
Santo André & 85,53 & 37,12 & 31,75 \\
São Caetano do Sul & 85 & 100 & 85 \\
\hline
\end{tabular}

Fonte: SNIS, 2015.

Nota:

* Dados não constam no Diagnóstico dos Serviços de Água e Esgotos - 2015, realizado pelo Sistema Nacional de Informações sobre Saneamento (SNIS).

** Os dados no Diagnóstico dos Serviços de Água e Esgotos - 2014 possuem valores equivalentes a $35 \%$ de tratamento do esgoto coletado e $24,20 \%$ de tratamento do esgoto gerado no município, havendo discrepância entre os dados de um ano para outro.

O Sistema Principal é composto por "cinco sistemas de esgotamento sanitário: Barueri, ABC, Parque Novo Mundo, São Miguel e Suzano, cada um deles constituído por uma rede de coletores, interceptores e uma grande estação de tratamento de esgotos - ETE", porém há os pontos de lançamentos provisórios, onde são lançados esgoto "in natura" em cursos d'água, fundos de vale e galerias de águas fluviais por não haver ligação das redes de coleta com os coletores tronco que encaminham o esgoto para as ETE's, tendo mais de 6.900 pontos de lançamento na RMSP (CBH-AT, 2014b, p. 3).

Em 2010, a RMSP contava com vinte e um Sistemas Isolados espalhados pela região periférica, os quais possuem basicamente a mesma estrutura que o Sistema Principal, porém as ETE's estão mais próximas dos pontos de coleta. Os Sistemas Isolados possuem a mesma problemática de falta de continuidade de algumas redes de coleta, descartando esgoto "in natura" (CBH-AT, 2014b). 
Segundo dados do SNIS, em 2015, 18.752 .507 habitantes foram atendidos com esgotamento sanitário, porém com uma média de 58,87\% e 53,31\% de esgoto coletado e tratado, respectivamente, equivalente a $31,38 \%$ de tratamento do esgoto gerado nos municípios da BH-AT. Estes porcentuais apontam para as redes de coleta de esgoto que não estão conectadas aos coletores e que, consequentemente, enviam os esgotos diretamente para os corpos hídricos da RMSP (CBH-AT, 2016). Entretanto, segundo dados da SABESP (2015c; 2017), atualmente os níveis de coleta e tratamento de esgoto são de $84 \%$ e $79 \%$, respectivamente, equivalendo a 66,36\% de tratamento do esgoto gerado nos municípios da BH-AT, excluindo os municípios responsáveis pelo seu sistema de saneamento básico.

Em relação aos investimentos de coleta e tratamento de esgoto, foi investido $R$ \$ 1,2 bilhão para "expansão da infraestrutura de coleta e tratamento de esgotos" em 2016 (SABESP, 2017, p. F-31). 


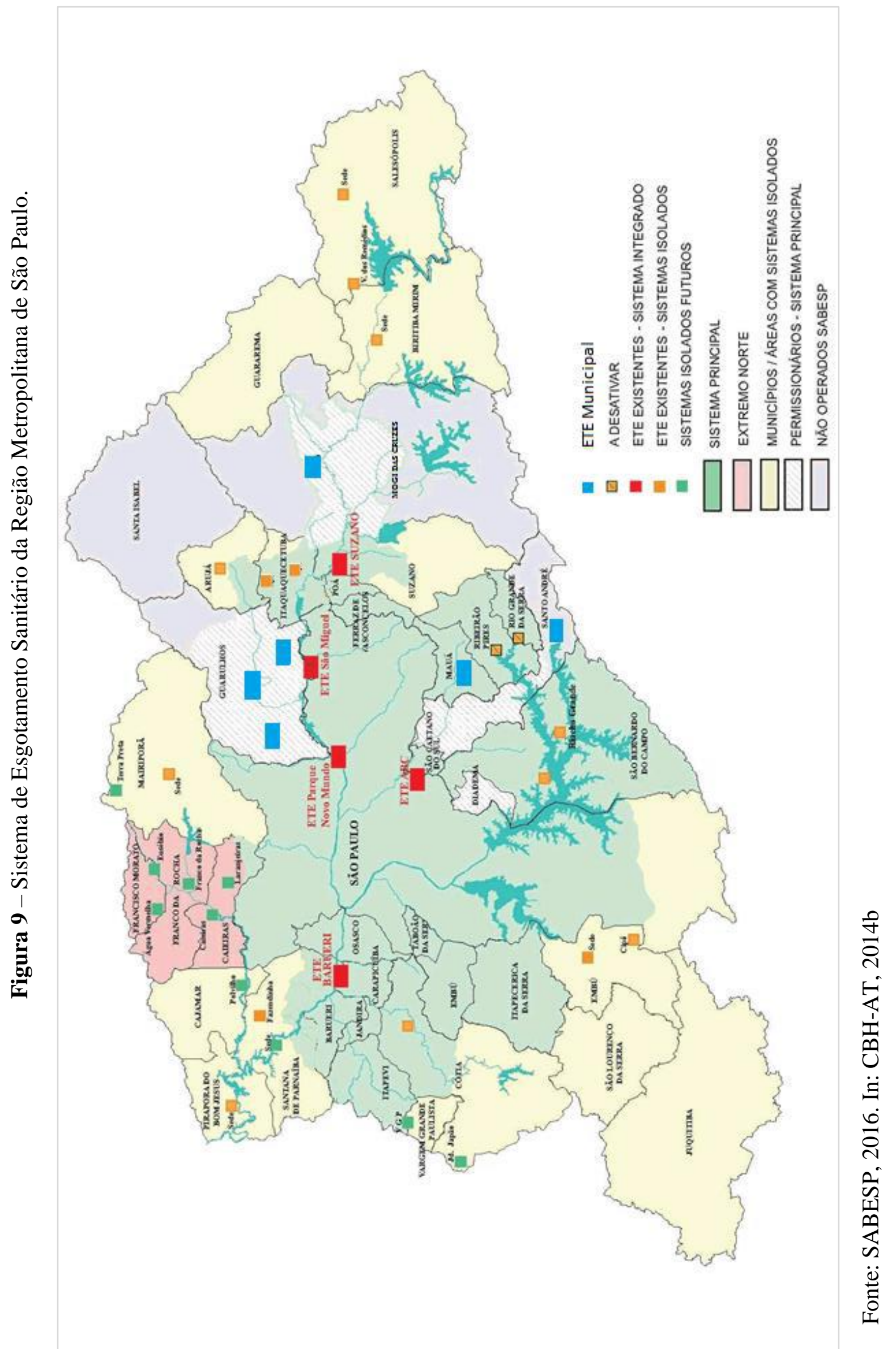




\subsubsection{COLETA E DESTINAÇÃO DE RESÍDUOS SÓLIDOS}

De acordo com a Lei Estadual $n^{\circ} 12.300$, de 16 março de 2006, os planos estaduais e regionais de resíduos sólidos devem atuar como instrumento da Política Estadual de Resíduos Sólidos, auxiliando na melhoria dos serviços e na gestão dos resíduos. O Plano Estadual de Resíduos Sólidos de 2014, utiliza a segmentação por região proposta pela EMPLASA e a SEADE, adotando a RMSP como uma unidade regional. Esta fragmentação é fundamental para a organização da gestão de acordo com as dinâmicas e o funcionamento de cada área.

Na RMSP, além do plano estadual, há os planos municipais de gerenciamento integrado de resíduos sólidos dos municípios Biritiba Mirim, Salesópolis, Poá, Suzano, Ferraz de Vasconcelos e Mogi das Cruzes; e o Plano Diretor de Resíduos Sólidos da Região Alto Tietê - Cabeceiras, revisado em 2006, que sugere um "modelo de gestão integrada e compartilhada de resíduos sólidos nos municípios envolvidos, o que, contudo, não foi viabilizado" (SÃO PAULO, 2014, p. 181). Devido ao tamanho da RMSP, o Plano Estadual propõe a gestão por sub-regiões "por meio da instalação de consórcios públicos, de parcerias público-privadas, de sociedade de propósito específico, entre muitas possíveis” (SÃO PAULO, 2014).

Segundo dados do SEADE (2017), em 2010, mais de 99\% da população que residia em moradias regulares na BH-AT contava com coleta de lixo (Figura 10). O indicador IGR (Índice de Qualidade de Gestão de Resíduos Sólidos), possui valores de 0 a 10, e é formulado a partir dos indicadores (CBH-AT, 2016):

- IQR: Índice de Qualidade de Aterro de Resíduos; e

- IQC: Índice de Qualidade de Usinas de Compostagem.

Segundo o inventário realizado pela CETESB, atualmente a BH-AT encontra-se com os seguintes valores de IGR:

Quadro 4 - Índice de Gestão de Resíduos Sólidos na Bacia Hidrográfica do Alto Tietê 2012.

\begin{tabular}{|c|c|}
\hline Município & IGR \\
\hline Arujá & 5,2 \\
\hline Barueri & 7,2 \\
\hline Biritiba Mirim & s.i. \\
\hline Caieiras & 4,9 \\
\hline Cajamar & s.i. \\
\hline Carapicuíba & 4,9 \\
\hline Cotia & 4,6 \\
\hline Diadema & 6,9 \\
\hline Embu das Artes & 5,5 \\
\hline Embu-Guaçu & 4,8 \\
\hline Ferraz de Vasconcelos & s.i.
\end{tabular}

\begin{tabular}{|c|c|}
\hline Município & IGR \\
\hline Jandira & s.i. \\
\hline Mairiporã & 6,1 \\
\hline Mauá & 7,5 \\
\hline Mogi das Cruzes & 6,4 \\
\hline Osasco & 5,7 \\
\hline Pirapora do Bom Jesus & s.i. \\
\hline Poá & 6,0 \\
\hline Ribeirão Pires & 7,0 \\
\hline Rio Grande da Serra & 4,0 \\
\hline Salesópolis & 8,3 \\
\hline Santana de Parnaíba & 6,3
\end{tabular}


Quadro 4 - Índice de Gestão de Resíduos Sólidos na BH-AT - 2012.

Continuação

\begin{tabular}{|c|c|c|c|}
\hline Município & IGR & Município & IGR \\
\hline Francisco Morato & s.i. & Santo André & 6,7 \\
\hline Franco da Rocha & 3,3 & São Bernardo do Campo & 7,6 \\
\hline Guarulhos & 8,5 & São Caetano do Sul & 6,5 \\
\hline Itapecerica da Serra & s.i. & São Paulo & 7,9 \\
\hline Itapevi & 6,1 & Suzano & 7,3 \\
\hline Itaquaquecetuba & s.i. & Taboão da Serra & 8,1 \\
\hline
\end{tabular}

Fonte: PMSP, 2014. In: CBH-AT, $2016 c$.

Nota:

* s.i.: sim informação.

Em compensação aos baixos valores de IGR, a BH-AT apresenta altos valores de IQR, tendo uma média de 8,8, sendo o município Osasco o único com IQR na faixa de inadequado, como mostra a Figura 11 (CETESB, 2016c). 


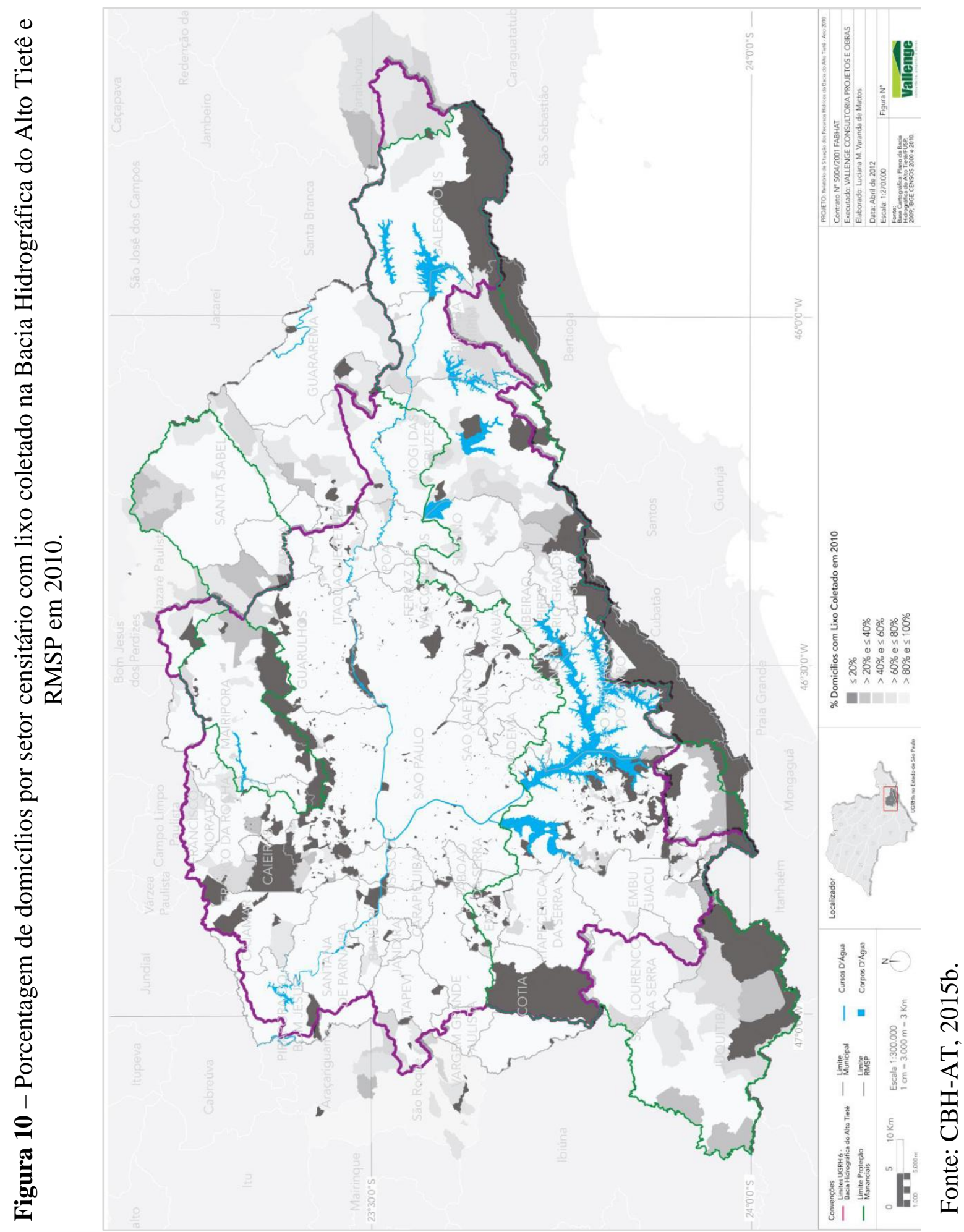




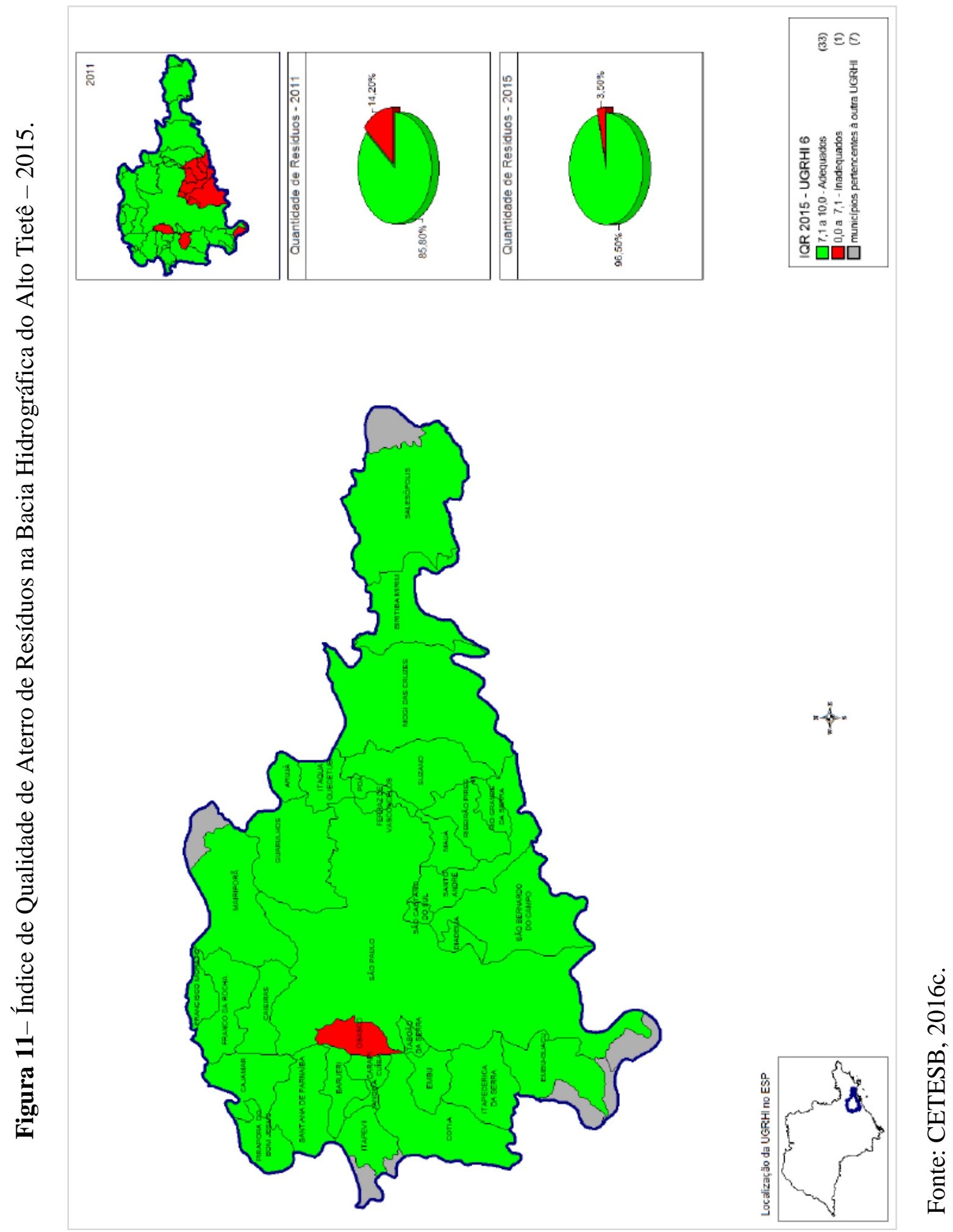




\subsubsection{DRENAGEM URBANA}

A BH-AT está localizada em uma região composta por várzeas inundáveis, muitas urbanizadas, agravando a ocorrência de enchentes. Com a necessidade de criação de mecanismos que auxiliassem na diminuição das inundações, ocorreu a criação da Câmara Técnica de Drenagem e Controle de Inundações, em 1997, com o intuito de definir as diretrizes para o Plano de Macrodrenagem (CBH-AT, 2009b).

O primeiro Plano de Macrodrenagem da Bacia Alto Tietê (PDMAT), atuou de forma mais efetiva "na bacia do rio Tamanduateí - incluindo as sub-bacias dos ribeirões dos Meninos e dos Couros, além do córrego do Oratório; bacia do Córrego Pirajuçara; bacia do Rio Aricanduva; calha do rio Tietê; bacia do ribeirão Vermelho; bacia do Médio Juqueri e bacia do Rio Baquirivu", buscando implantar soluções e melhorias hidráulicas nos rios Tietê e Tamanduateí, estabelecendo vazão máxima suportada pela calha do rio Tietê (CBH-AT, 2014c, p. 3).

A atualização do PDMAT, concluída em 2010, recomendou a implantação de parques lineares, a unificação dos procedimentos de análise hidráulica e hidrológica, introduziu "a solução em polder, estrutura constituída de muro em concreto ou dique em solo, implantada ao longo das margens do rio que atua como barreira contra o seu transbordamento" e enfatizou a utilização de medidas não estruturais como educação ambiental, monitoramento e sistema de alerta (CBH-AT, 2014c, p. 4).

A RMSP conta com cinquenta e um reservatórios de detenção, os chamados piscinões, em operação (CBH-AT, 2014c). O próprio CBH-AT afirma que entre os serviços de saneamento, o de drenagem é o que possui menor estrutura e que apesar do PDMAT ter sido atualizado para a versão 3 em 2014, até o momento não houve discussão sobre o mesmo dentro do comitê (CBH-AT, 2016). O CBH-AT (2014c, p. 24) concluiu que:

Além de estruturas de drenagem em si, torna-se necessário maior controle do uso e ocupação do solo nos municípios que compõem a BHAT e implantação de medidas compensatórias para reduzir o volume de água escoado durante as tormentas para minimizar o efeito das enchentes. A diretriz não pode mais ser de acelerar as águas a jusante, pois atualmente sempre haverá alguém nessa posição geográfica. As canalizações foram um paradigma seguido durante anos, tendo vista a riqueza da rede hidrográfica que drena a RMSP. Muito comum e foi até sinônimo de "modernidade" a canalização de córregos e construção de avenidas de fundo de vale.

Há um limite na aceleração das águas pluviais para jusante, procurando afastá-las do local onde se precipitaram sobre o solo. Quando eram poucas as áreas impermeabilizadas e que afastavam o quanto antes as águas pluviais, entendia-se essa solução. No entanto, com o agigantamento da área urbana da RMSP, um volume muito maior de água passou a chegar nos fundos de vale, aumentando a frequência de inundações, frequência muito maior que aquela que 
seria natural para os rios que estão submetidos ao regime hidrológico típico do Planalto Paulistano.

\subsection{QUALIDADE DAS ÁGUAS}

\subsection{1. ÁGUAS SUPERFICIAIS}

A CETESB realiza o monitoramento da qualidade das águas por meio de índices como Qualidade de Água (IQA), Preservação da Vida Aquática (IVA), Qualidade de Águas Brutas para Fins de Abastecimento Público (IAP) e Índice de Estado Trófico (IET). Há poucos pontos de coleta na área mais urbanizada na BH-AT e nos principais rios da região metropolitana, como o rio Pinheiros e Tietê, estando a amostragem mais concentrada próximo aos reservatórios, havendo grande parte da área central da bacia com pouco ou nenhum local amostrado (Figura 12).

Segundo o último relatório da CETESB, para o IQA que é composto de variáveis básicas como coliformes fecais, pH, Demanda Bioquímica de Oxigênio (DBO), nitrogênio total, fósforo total, temperatura, turbidez, resíduo total e Oxigênio Dissolvido (OD), foram monitorados 70 pontos de amostragem ao longo da BH-AT, tendo dessa amostragem o seguinte resultado (CETESB, 2016a, 2016d):

Tabela 4 - Distribuição porcentual das categorias do IQA na Bacia Hidrográfica do Alto Tietê em 2015.

\begin{tabular}{|c|c|c|c|c|}
\hline \multicolumn{5}{|c|}{$\%$ de pontos da amostragem em cada categoria do IQA } \\
\hline Ótima & Boa & Regular & Ruim & Péssima \\
\hline 11 & 20 & 7 & 26 & 36 \\
\hline
\end{tabular}

Fonte: CETESB, 2016a.

A maior concentração de pontos na categoria Péssima está nos locais mais urbanizados da BH-AT (Figura 13). Apesar de apresentar 36\% dos pontos em péssimo estado, totalizando mais de $60 \%$ em situação ruim ou péssima, entre 2014 e 2015 , houve aumento de $4 \%$ no porcentual de pontos nas categorias Boa e Regular nos corpos hídricos localizados em áreas industriais e adensadas como as regiões metropolitanas de São Paulo (porcentagem conta região metropolitana de São Paulo, Campinas e São José dos Campos) (CETESB, 2016a). Um aspecto que pode estar auxiliando na melhoria da qualidade dos corpos hídricos na BH-AT é o Projeto Córrego Limpo. Segundo a SABESP (2015c, p. 46), em estudo realizado com a medição de 36 rios e córregos de São Paulo, entre março de 2014 e fevereiro de 2015, o porcentual de amostras nas categorias Regular e Boa "subiu de 25\% para 55,4\%, enquanto o 
número de pontos de coleta com qualidade ruim ou péssima caiu de $74,9 \%$ para $44,3 \%$ ". Sobre a análise estadual (CETESB, 2016a, p. 189):

\begin{abstract}
Nos pontos em que foi possível identificar o motivo provável da melhora, constata-se um efeito positivo na qualidade da água relacionado principalmente a melhorias no sistema de saneamento básico, como implantação ou ampliação de ETE's e redes coletoras de esgoto.

Já em relação aos pontos que apresentaram tendência de piora, relacionou-se a influência do período prolongado de seca no último ano, que diminuiu a capacidade de diluição dos rios, ainda refletindo na qualidade dos corpos hídricos, carga difusa urbana, problemas na operação de ETE's, e aumento das ocupações irregulares.
\end{abstract}

A poluição difusa que está ligada à poluição em decorrência das chuvas, está intimamente relacionada aos menores índices de qualidade das águas, apresentando nas épocas de estiagem melhores resultados com maior porcentual de qualidade nas categorias Bom e Ótimo (CETESB, 2016a).

O IVA é um importante instrumento para definir pontos críticos em relação a qualidade da água para a proteção da vida aquática. Sua função é avaliar os níveis de toxicidade e elementos essenciais aos seres aquáticos como OD e $\mathrm{pH}$, e "avaliar a qualidade da água quanto ao enriquecimento por nutrientes" (ZAGATTO, et al., 1999, p. 115).

Assim como o IQA, o IVA também apresentou mais de $60 \%$ dos pontos nas categorias Ruim e Péssima, afirmando a fragilidade da vida aquática na região como mostram a Tabela 5 e a Figura 14:

Tabela 5 - Distribuição porcentual das categorias do IVA na Bacia Hidrográfica do Alto Tietê em 2015.

\begin{tabular}{|c|c|c|c|c|}
\hline \multicolumn{5}{|c|}{$\%$ de pontos da amostragem em cada categoria do IVA } \\
\hline Ótima & Boa & Regular & Ruim & Péssima \\
\hline 5 & 10 & 15 & 36 & 33 \\
\hline
\end{tabular}

Fonte: CETESB, 2016a.

Já o IAP é amostrado apenas em rios e reservatórios destinados ao abastecimento, com pontos de coleta nos locais de captação de água para abastecimento, sendo o índice composto pelo IQA e o Índice de Substâncias Tóxicas e Organolépticas (ISTO). O ISTO não inclui apenas limites inferior e superior das substâncias cádmio, chumbo, cromo total, níquel, mercúrio, PFTHM (Potencial de Formação de Trihalometanos), alumínio, cobre, manganês e 
zinco, mas também o número de células de cianobactérias amostradas (CETESB, 2016a, 2016d). O IAP possui classificação de Ótima a Péssima:

- Ótima: $79<\mathrm{IAP} \leq 100$

- Boa: $51<\mathrm{IAP} \leq 79$

- Regular: $36<$ IAP $\leq 51$

- Ruim: $19<\mathrm{IAP} \leq 36$

- Péssima: IAP $\leq 19$

$\mathrm{Na}$ BH-AT, foram amostrados para análise do IAP 22 pontos no ano de 2015, conforme Tabela 6 e Figura 15:

Tabela 6 - Médias anuais do IAP na Bacia Hidrográfica do Alto Tietê, em 2015.

\begin{tabular}{|c|c|c|c|}
\hline Corpo hídrico & Ponto & $\begin{array}{c}\text { Número de } \\
\text { amostras }\end{array}$ & IAP \\
\hline Braço do Ribeirão Taquaquecetuba & BITQ 00100 & 9 & 17 \\
\hline Braço do Rio Pequeno & BIRP 00500 & 9 & 40 \\
\hline Reservatório Águas Claras & ACLA 00500 & 12 & 81 \\
\hline \multirow{3}{*}{ Reservatório Billings } & BILL 02030 & 4 & 8 \\
\cline { 2 - 4 } & BILL 02100 & 4 & 24 \\
\cline { 2 - 4 } & BILL 02500 & 4 & 41 \\
\cline { 2 - 4 } & BILL 02900 & 4 & 45 \\
\hline Reservatório das Graças & COGR 00900 & 4 & 20 \\
\hline Reservatório de Tanque Grande & TGDE 00900 & 4 & 69 \\
\hline Reservatório do Cabuçu & RCAB 00900 & 4 & 55 \\
\hline Reservatório do Guarapiranga & GUAR 00900 & 4 & 62 \\
\hline Reservatório do Juqueri ou Paiva Castro & JQJU 00900 & 12 & 73 \\
\hline \multirow{2}{*}{ Reservatório do Rio Grande } & RGDE 02030 & 3 & 18 \\
\cline { 2 - 4 } & RGDE 02200 & 4 & 36 \\
\cline { 2 - 4 } & RGDE 02900 & 10 & 69 \\
\hline Reservatório do Rio Jundiaí & JNDI 00500 & 4 & 16 \\
\hline Reservatório Taiaçupeba & PEBA 00900 & 10 & 29 \\
\hline Ribeirão dos Cristais & CRIS 03400 & 4 & 56 \\
\hline Rio Cotia & COTI 03900 & 4 & 9 \\
\hline Rio Grande ou Jurubatuba & GADE 02900 & 4 & 10 \\
\hline Rio Taiaçubeba-Mirim & TAIM 00800 & 3 & 5 \\
\hline Rio Tietê & TIET 02090 & 4 & 25 \\
\hline & & & \\
\hline
\end{tabular}

Fonte: CETESB, 2016a.

A partir da tabela de resultados apresentada pela CETESB (2016a, p. 155), não há homogeneidade na coleta de amostras para análise de IAP, havendo apenas dois pontos com coleta em todos os meses do ano. De acordo com o mapa de localização dos pontos de coleta, os locais que apresentam os piores índices são: Rio Taiaçupeba-Mirim, logo após o reservatório de Taiaçubepa, o primeiro ponto da represa Billings (BILL 02030) e Rio Grande ou Jurubatuba, próximo ao reservatório do Rio Pequeno. Apesar de haver reversão parcial das 
águas dos rios Tietê e Tamanduateí para evitar inundações, estes não são colocados como pontos de coleta apesar de influenciarem no aumento de algas nos reservatórios Billings e Guarapiranga, como aponta SILVA (2015).

Segundo CETESB (2016a), o PFTHM influenciou de forma relevante diversas campanhas localizadas na UGRHI 06. Os corpos hídricos do Rio Cotia e Braço do Ribeirão Taquacetuba apresentaram piora entre os anos 2010 e 2015, tendo resultados de IAP de 28 para 9 e 53 para 17, respectivamente, tendo com justificativa, provavelmente, a diminuição da intensidade de chuva nos últimos anos, diminuindo a capacidade de diluição e a piora do estado trófico. É importante lembrar que os

O IET avalia e classifica os corpos hídricos de acordo com a qualidade da água, o enriquecimento por nutrientes "e seu efeito relacionado ao crescimento excessivo de algas e cianobactérias" (CETESB, 2016d, p. 10). Em 2015 foram calculados valores de fósforo total e clorofila $a$, tendo 45 pontos de amostragem na BH-AT, dos quais pode-se considerar $62 \%$ eutrofizados (eutrófico, supertrófico e hiperrtrófico), 31\% em processo de eutrofização e apenas 7\% com baixa trofia (CETESB, 2016a), de acordo com a Tabela 7 e a Figura 16:

Tabela 7 - Porcentual do Índice de Estado Trófico na Bacia Hidrográfica do Alto Tietê em 2015.

\begin{tabular}{|l|c|}
\hline \multicolumn{1}{|c|}{ Estado trófico } & Porcentual \\
\hline Ultraoligotrófico & - \\
\hline Oligotrófico & 7 \\
\hline Mesotrófico & 31 \\
\hline Eutrófico & 31 \\
\hline Supertrófico & 18 \\
\hline Hipertrófico & 13 \\
\hline
\end{tabular}

Fonte: CETESB, 2016a. 


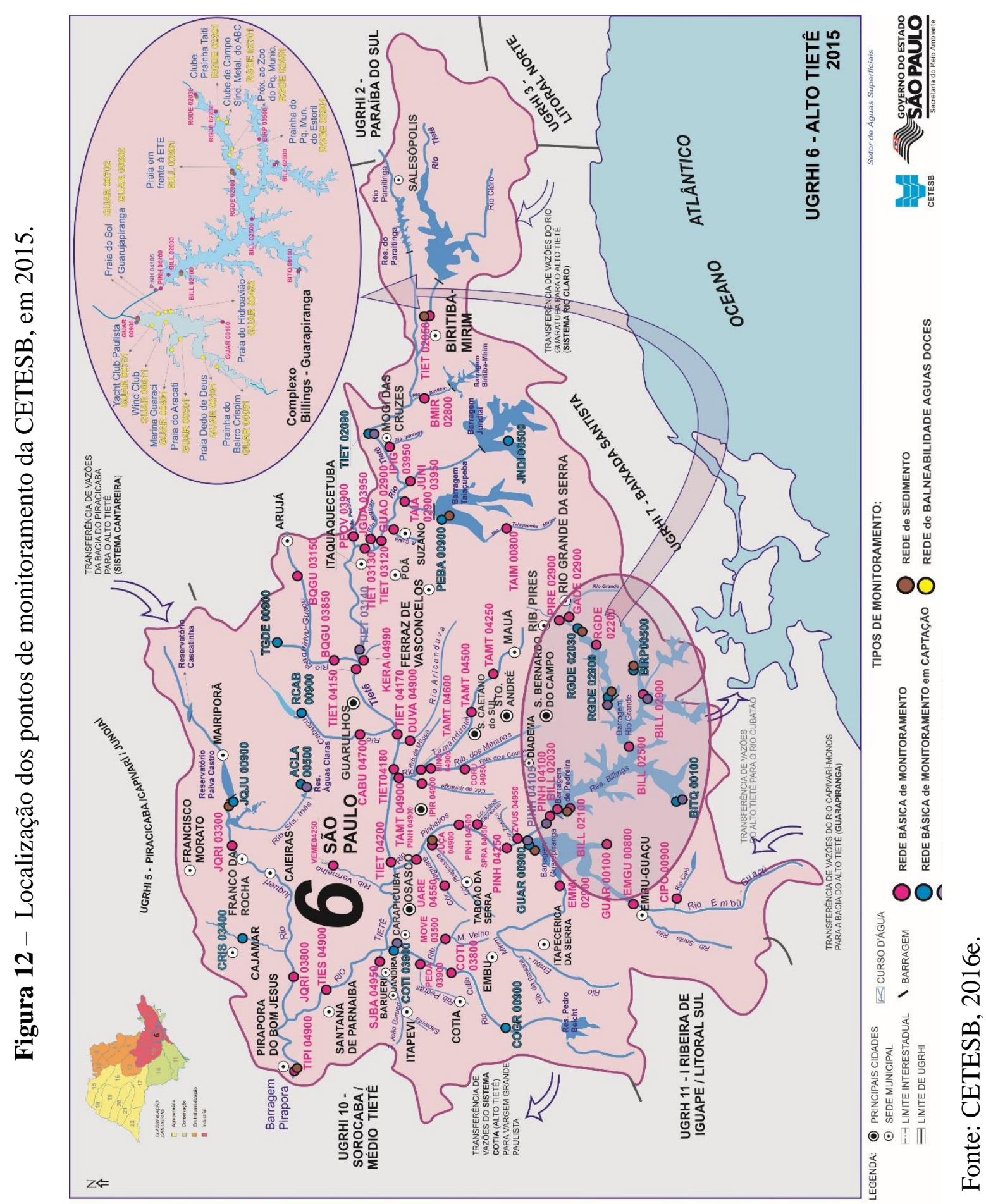




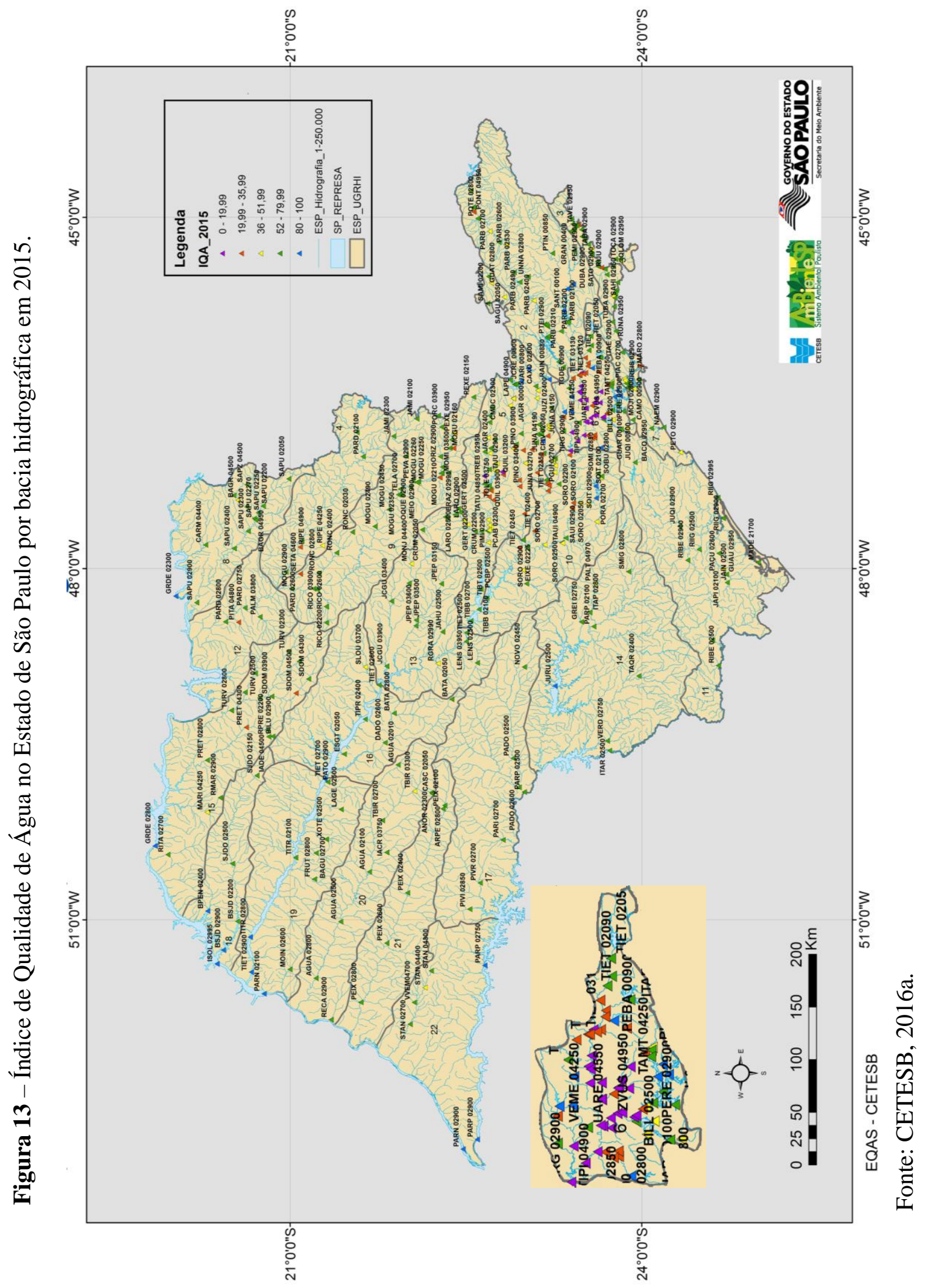




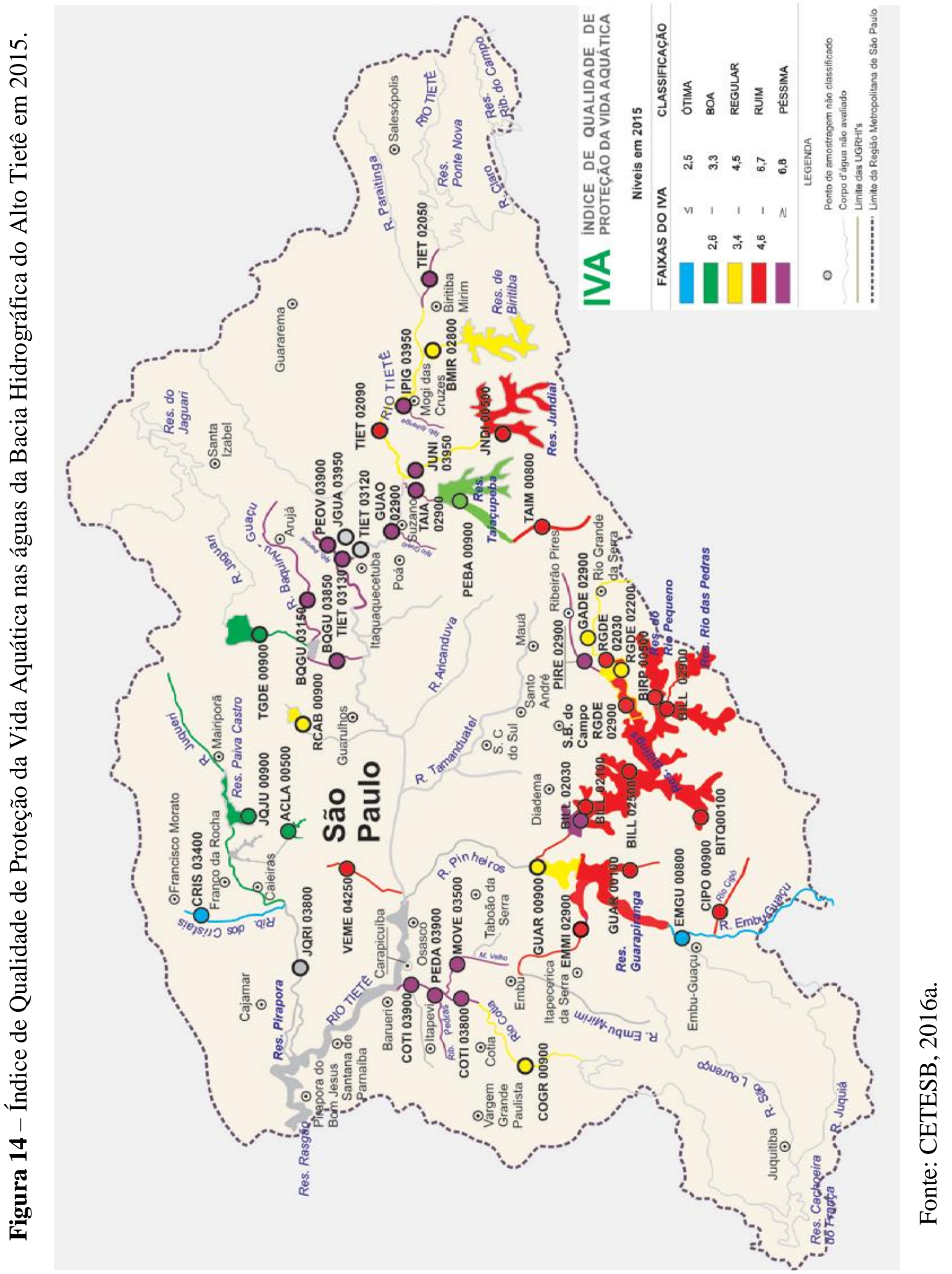




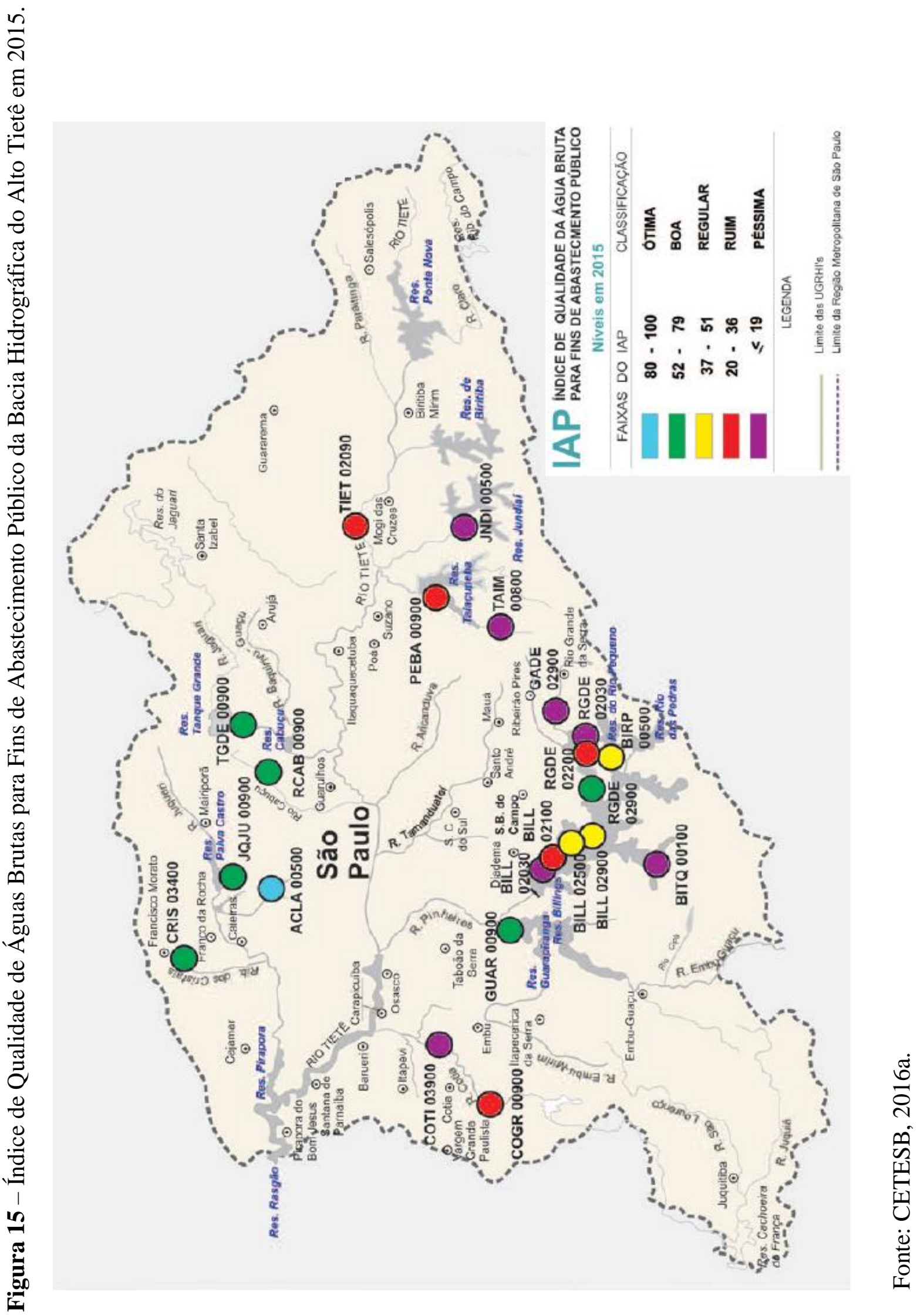




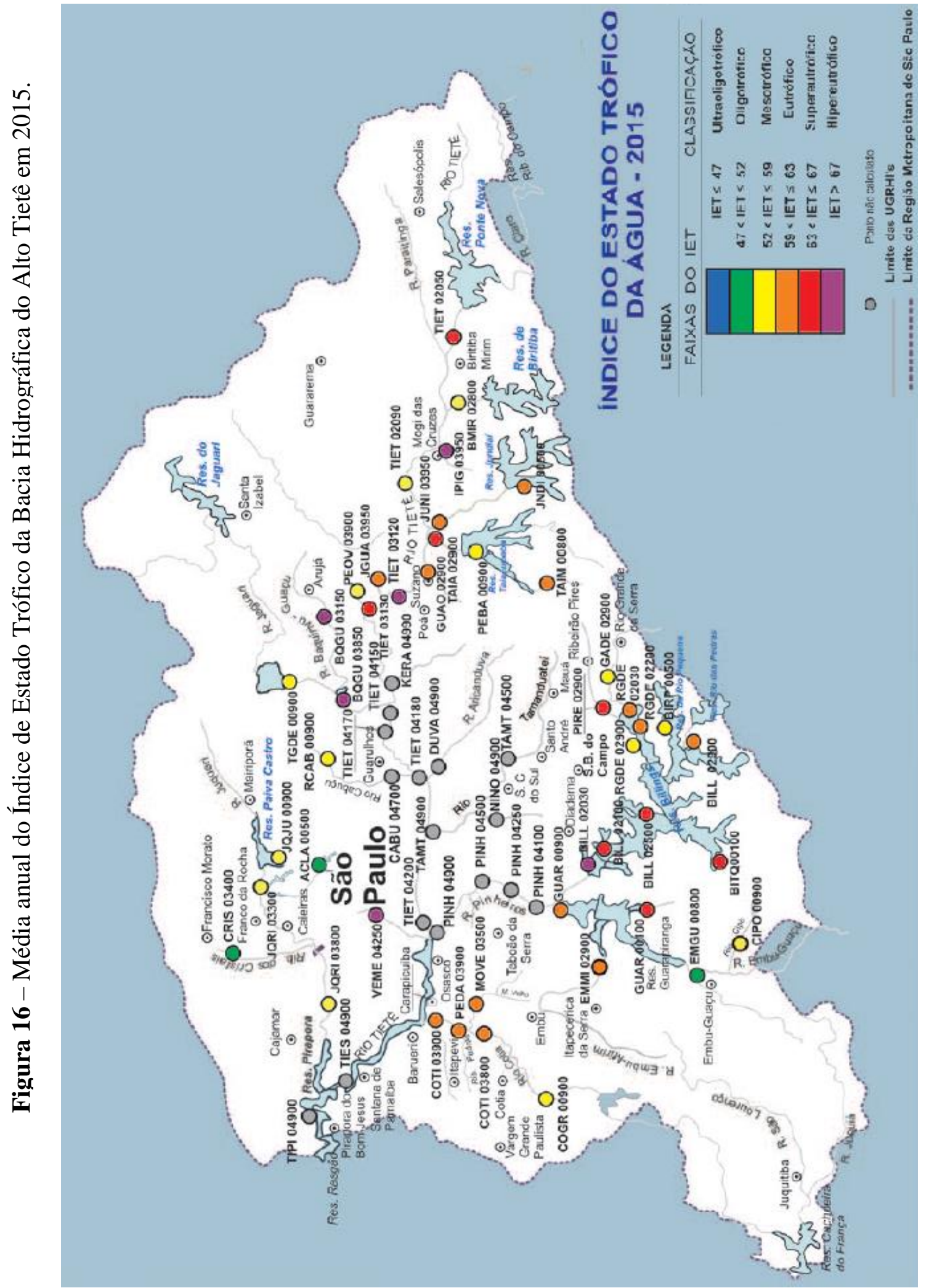

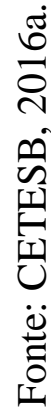




\title{
2.5.2. ÁGUAS SUBTERRÂNEAS
}

Há na BH-AT dois aquíferos: o Sistema Aquífero Cristalino (Pré-Cambriano) e o Sistema Aquífero Sedimentar (São Paulo). O aquífero Pré-Cambriano possui duas unidades distintas, sendo uma delas o aquífero cristalino propriamente dito "onde as águas circulam por descontinuidades rúpteis da rocha", consistindo de uma unidade "de caráter livre a semi-livre e heterogêneo e anisotrópico" e a outra unidade está relacionada às rochas intemperizadas, de natureza livre, formando um aquífero de porosidade heterogênea. Já o aquífero São Paulo é mais explorado e possui um sistema "livre a semi-confinado, de porosidade primária e bastante heterogêneo" (HIRATA e FERREIRA, 2001, p. 44). CONICELLI (2014, p. 76) disserta que:

\begin{abstract}
A recarga dos sistemas aquíferos está associada à infiltração natural de parte das águas do excedente hídrico (precipitação menos a evapotranspiração, o escoamento superficial e a interceptação), das fugas das redes públicas de distribuição de água e, mais restritamente, da rede coletora de esgotos e da infiltração direta de uma parcela da água das galerias pluviais que, devido à manutenção deficiente, infiltram a água da chuva, além das ligações clandestinas de esgoto.
\end{abstract}

De acordo com a Figura 17, é possível verificar que as menores taxas de recarga dos aquíferos estão localizadas em toda a região mais periférica da BH-AT.

Existem na BH-AT vinte e oito pontos monitorados pela CETESB (2016b, p. 122), sendo eles "poços utilizados para abastecimento público, serviços, produção de águas minerais, além de nascentes" (Figura 18). A exploração dos aquíferos predomina sobre o aquífero Pré-Cambriano, com mais de 70\% dos poços cadastrados no DAEE (CONICELLI, 2014).

As águas subterrâneas são avaliadas de acordo com suas características, analisando parâmetros físicos, químicos, microbiológicos e a atividade estrogênica. No último relatório de Qualidade das Águas Subterrâneas no Estado de São Paulo 2013-2015 (CETESB, 2016b), foram verificados quatorze pontos com não conformidades, tendo oito deles apresentado valores acima do máximo permitido de ferro, sete apresentaram alta quantidade de bactérias heterotróficas, quatro obtiveram amostras com coliformes fecais e três apresentaram valores acima do máximo permitido de arsênio.

O método GOD (Groundwater occurrence, Overall lithology of the unsaturated zone, Depth to the water table), desenvolvido pela Organização Mundial da Saúde, avalia a vulnerabilidade de contaminação dos aquíferos considerando o nível de inacessibilidade hidráulica da zona saturada e a capacidade do aquífero de atenuar os estratos de cobertura da porção saturada do aquífero. A avaliação é feita a partir da análise do grau de confinamento da água subterrânea, da ocorrência de estratos de cobertura e da distância até o lençol freático 
ou o teto do aquífero confinado, tendo as seguintes classes de vulnerabilidade (FOSTER et al., 2006, p. 19):

- Extrema - vulnerável à maioria dos contaminantes com impacto rápido em muitos cenários de contaminação;

- Alta - vulnerável a muitos contaminantes em muitas condições de contaminação, exceto os que são fortemente adsorvidos ou rapidamente transformados;

- Moderada - vulnerável a alguns contaminantes, mas somente quando continuamente lançados ou lixiviados;

- Baixa - vulnerável somente a contaminantes conservadores, a longo prazo, quando contínua e amplamente lançados ou lixiviados;

- Insignificante - presença de camadas confinantes sem fluxo vertical significativo de água subterrânea (percolação).

CONICELLI (2014) aponta que segundo análise realizada pelo método GOD, mais de $80 \%$ da BH-AT apresenta índice de vulnerabilidade moderada, conforme Figura 19. O autor ainda avaliou a criticidade de possíveis contaminações, avaliando empreendimentos com potencial de contaminação do solo e das águas subterrâneas de acordo com as atividades realizadas (cruzamento de áreas críticas de qualidade e de quantidade), considerando-as como áreas críticas, sendo identificados "930 áreas de 500x500m com maior preocupação, seguida de 1876 áreas de média e 3120 áreas de baixa criticidade", mostradas na Figura 20 (CONICELLI, 2014, p. 132). 


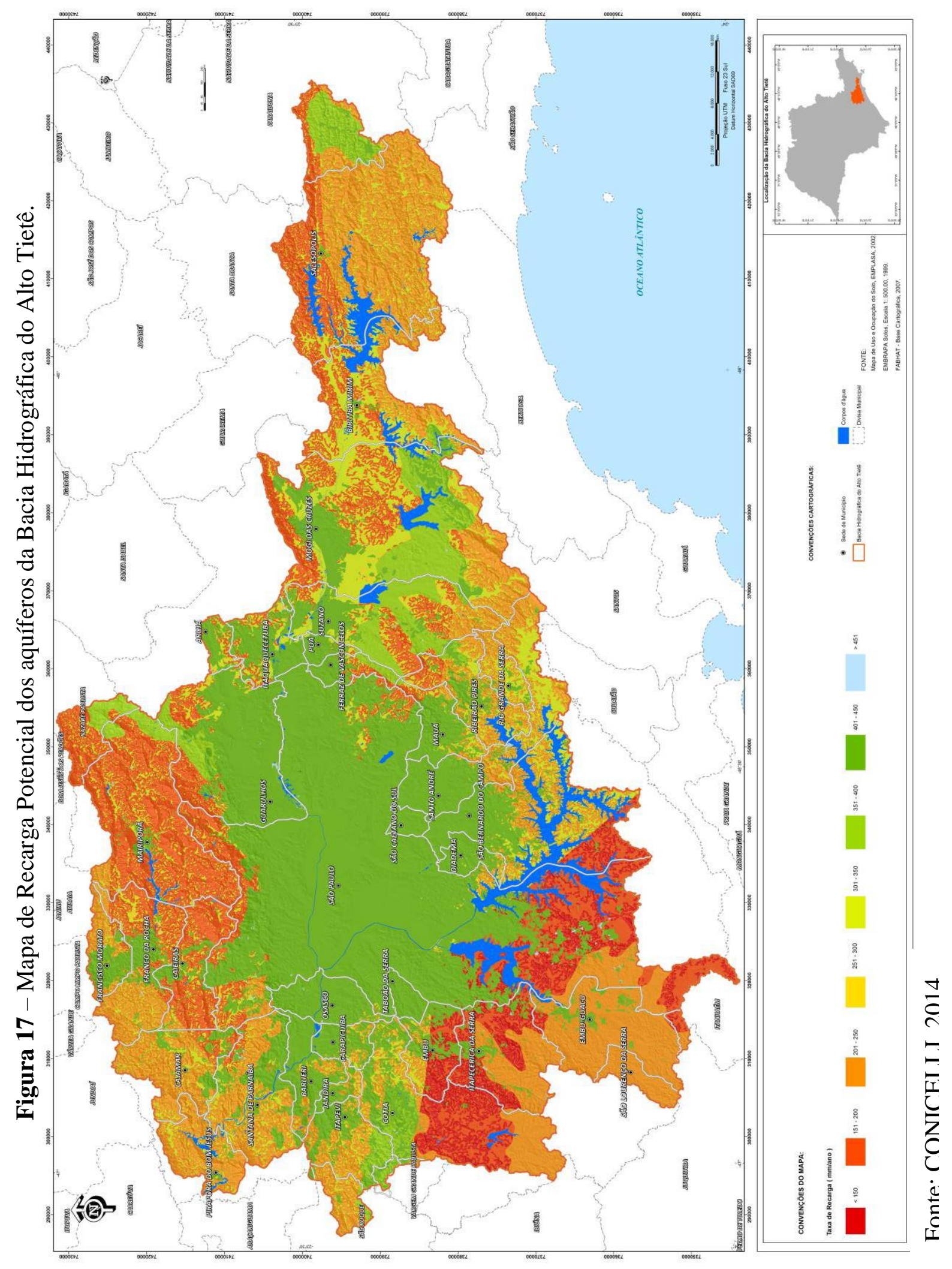




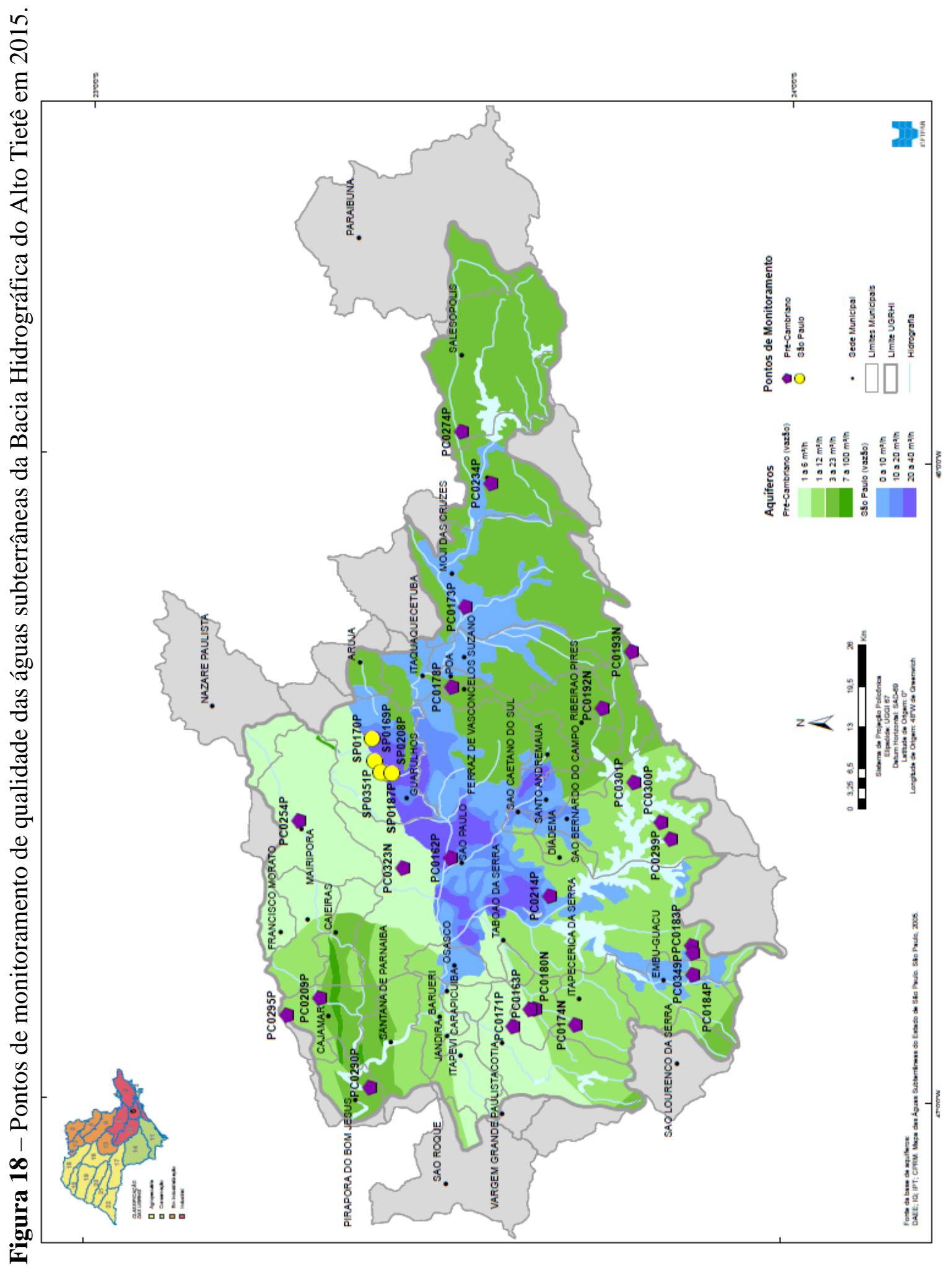

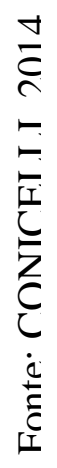




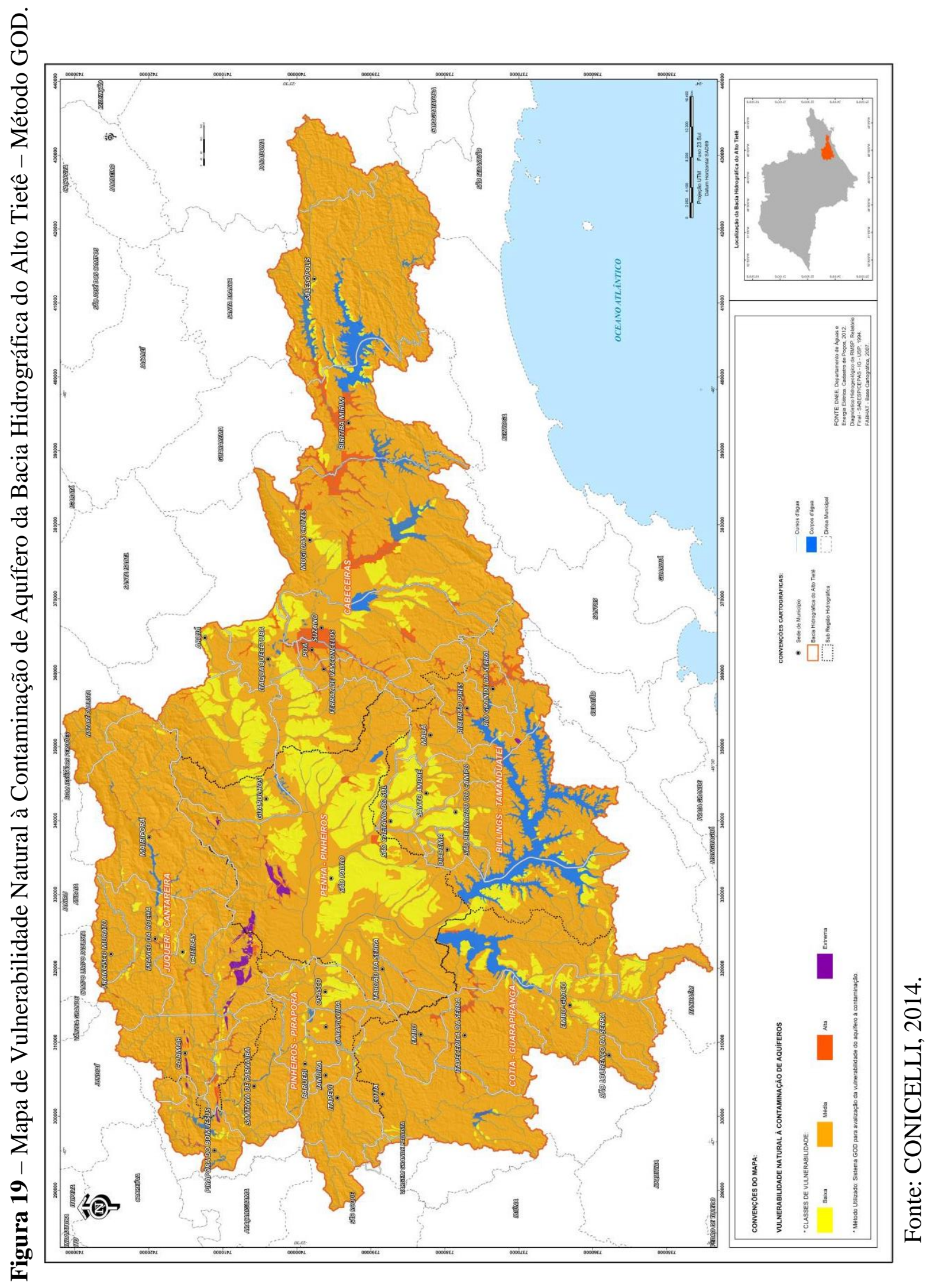




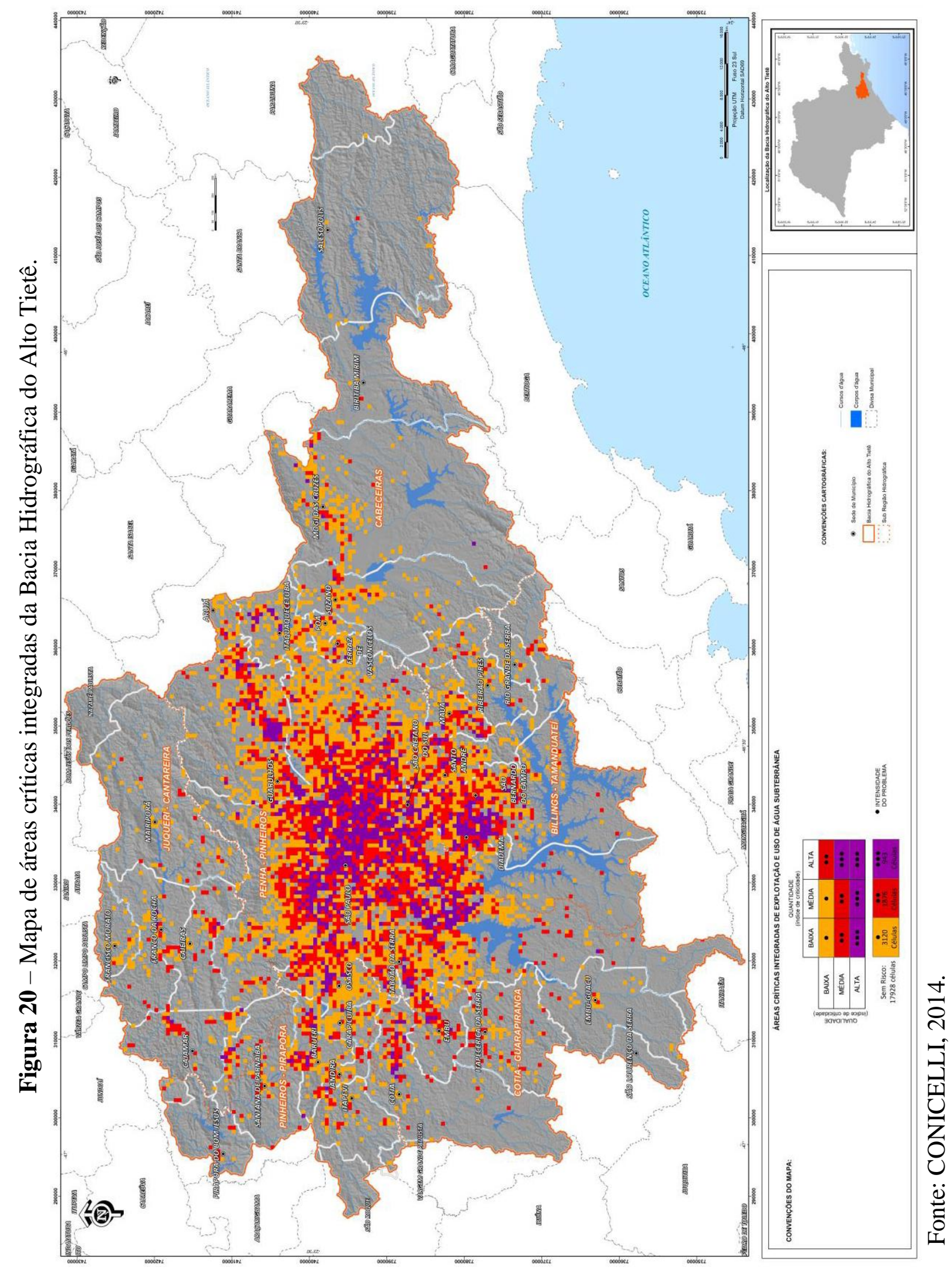




\section{CAPÍTULO 3 - RESULTADOS E DISCUSSÃO}

\subsection{ANÁLISE DE ATAS E DELIBERAÇÕES DO CBH-AT}

Apesar da Lei Estadual ter sido aprovada em 1991, apenas em 1994 formalizou-se a criação do CBH-AT e foram iniciados os registros. As primeiras deliberações anexadas separadamente das atas estão datadas a partir de 1996. Desta forma, serão adicionadas nesta análise apenas as deliberações pertinentes, assim como serão citados apenas os projetos indicados pelo CBH-AT para recebimento de recursos do FEHIDRO que forem relevantes ao tema proposto do trabalho e dos temas definidos na metodologia, os quais são:

- Abastecimento;

- Poluição;

- Despoluição;

- Melhorias da qualidade da água;

- Uso e ocupação do solo;

- Destinação de recursos financeiros;

- Educação ambiental; e

- Demais temas que envolviam a qualidade ou recuperação de corpos hídricos.

Constam no Anexo A a síntese das atas, no Anexo B os dados das deliberações e no Anexo $\mathrm{C}$ os projetos aprovados para recebimento de recursos do FEHIDRO.

\section{$-\underline{1994}$}

O CBH-AT teve sua formação oficializada em 18 de novembro de 1994, tendo como presidente o prefeito de Itapecerica da Serra, Helio Rubens Figueiredo.

O primeiro comentário foi do representante da ELETROPAULO a respeito da Usina Henry Borden com o objetivo de nivelar o conhecimento dos participantes do comitê sobre o assunto e explicar que a capacidade de produção de energia elétrica da usina não estava sendo alcançada. Desta forma foi solicitado o aumento do bombeamento de $20 \mathrm{~m}^{3} / \mathrm{s}$ para $35 \mathrm{~m}^{3} / \mathrm{s} \mathrm{na}$ média semanal. Um dos presentes, representante do Movimento de Defesa da Vida, se manifestou de forma negativa ao pedido da ELETROPAULO, diante dos riscos que esse bombeamento a mais poderia causar ao manancial.

Outro assunto muito discutido foi o Plano de Gestão de Integração das três bacias Alto Tietê, Piracicaba e Baixada Santista (Planão), elaborado em consórcio com a empresa HIDROPLAN. O Planão estava em fase de elaboração, sendo feitas pesquisas e análise de alternativas emergenciais que suprissem o problema do abastecimento. Ante a necessidade de dar andamento no Planão, foi aprovada a concentração de recursos voltados aos estudos para a elaboração do projeto. 
O vice-presidente do CBH-AT, Mario César Mantovani, representante da Sociedade Civil, entre outros assuntos coloca em pauta o problema da empresa Manikraft que se localizava dentro da área da represa de Taiaçupeba e a contaminava com resíduos industriais. Diante de diversas explanações sobre o assunto dos demais representantes do comitê, pode-se observar as divergências encontradas em relação às prioridades do poder público, pois a demora dos trâmites legais para a retirada da empresa prejudicava o abastecimento da região, não havendo possibilidade de aumentar a capacidade do reservatório devido à localização da Manikraft. Aprovou-se o encaminhamento de moção de repúdio diante da permanência da empresa no local.

$-\underline{1995}$

O ano iniciou-se com uma reunião dedicada às soluções de curto, médio e longo prazo voltadas à diminuição da ocorrência de inundações na região da bacia. Com isso, criou-se a Câmara Técnica para definir diretrizes e encaminhar sugestões para a concepção de um "Plano Integrado de Intervenção do Estado, Municípios e da Sociedade Civil" com o objetivo de minimizar as problemáticas que envolvem o tema e tratou-se da regularização da várzea do rio Tietê com medidas não-estruturais que auxiliassem na minimização das enchentes.

Ao longo do ano foram realizadas quatro reuniões nas quais os principais assuntos tratados constituíram as seguintes temáticas:

- O Projeto Tietê e o rio Pinheiros, tratando de assuntos sobre a despoluição e o controle de inundações, trabalhando os dois rios de forma conjunta e incluindo-os como temas prioritários do Plano Estadual de Recursos Hídricos 96/99. O Secretário da Secretaria de Recursos Hídricos, Saneamento e Obras - SRHSO, Hugo Marques da Rosa, exaltou a necessidade de trabalhar junto com a sociedade civil para minimizar os impactos de poluição das águas dos rios;

- A situação da represa Billings, sendo muito discutida a proibição de descarte de dejetos na represa, tendo consequências em outros municípios devido ao alto grau de poluentes lançados nos rios e as alternativas apresentadas pela HIDROPLAN baseadas em seus possíveis usos;

- O Planão, contando com a criação de uma Câmara Técnica para acompanhar os estudos concentrados principalmente na represa Billings; e

- A Lei de Proteção de Mananciais que estava sendo criada e resultou na formação da Câmara Técnica de revisão da lei e no pedido de liberação de recursos para que esta revisão pudesse ter continuidade.

Em todas as reuniões a represa Billings e o rio Tietê foram pelo menos lembrados por algum membro do comitê, mostrando a preocupação com a poluição dos mesmos, porém sem citar os demais afluentes e rios da bacia. Nas duas últimas reuniões do ano, foram citados assuntos sobre o saneamento e a necessidade de aumentar a rede de tratamento de esgotos para auxiliar nos projetos de despoluição. 
Alguns prefeitos colocaram em pauta suas preocupações em relação à Lei de Proteção de Mananciais, a qual estava sendo atualizada desde o ano anterior e recomendava que não fossem realizadas obras públicas até a sua revisão. Esta medida preocupou-os devido às cidades possuírem grande parte de seu território em áreas de proteção, limitando o crescimento urbano. A Lei n. 9.866/1997 dispõe sobre a proteção e recuperação de bacias hidrográficas e dos mananciais de interesse regional, a qual é de extrema importância para a preservação dos recursos. Em outra reunião foi proposta a concepção de uma lei generalista em âmbito estadual para que fosse possível a criação de leis por bacia ou sub-bacia, podendo desta forma encaixar as necessidades de cada região.

Discutiu-se sobre o Projeto Billings que buscava efetivar ações para melhorar a qualidade da água. A escassez de água na RMSP ocorrida no ano foi colocada, pontuando que a região era a mais afetada pelos rodízios e a falta de saneamento, discussão essa que rendeu uma reunião apenas voltada para este assunto e as preocupações com captação de água, os projetos de estações de tratamento de esgoto e a falta de compatibilidade entre as cidades da região metropolitana. Em vista da escassez, o representante da SABESP explanou sobre o Plano Metropolitano da Água, o qual fazia parte de um projeto maior composto pelo plano e pelos programas: de Redução de Perdas, Uso Racional da Água e de Reúso Planejado da Água.

Neste ano foi formalizado o convênio entre a prefeitura do município de São Paulo e o CBH-AT, de forma que a prefeitura se dispôs a alocar recursos financeiros para dar continuidade no Planão.

Na Deliberação ${ }^{\circ}$ 01/96, de 30 de agosto, se aprovaram os critérios para distribuição de recursos do FEHIDRO, dando prioridade aos programas que constavam no Plano Estadual de Recursos Hídricos 1996-1999, chamados de Programas de Duração Continuada. Estes programas foram definidos pela Lei Estadual $\mathrm{n}^{\circ}$ 9.034, de 27 de dezembro de 1994 (atualmente revogada pela Lei Estadual $n^{\circ} 16.337$, de 14 de dezembro 2016) e elaborados pelos comitês das bacias, para padronizar a gestão dos recursos hídricos de acordo com as prioridades estabelecidas pela lei.

Dentre estes programas havia o de Serviços e Obras de Proteção e Recuperação da Qualidade das Águas, o qual foi incluso na lista de prioridades para o comitê. Dando continuidade às premissas da distribuição dos recursos financeiros, na Deliberação 03/96, de 11 de novembro, foram indicados sete projetos para serem contemplados (Quadro 5). 
Quadro 5 - Lista de projetos indicados para recebimento de recursos financeiros do FEHIDRO no ano 1996.

\begin{tabular}{lcc}
\hline \multicolumn{1}{c}{ Projeto } & $\begin{array}{c}\text { Subcomitê atendido } \\
\text { com recurso }\end{array}$ & Investimento \\
\hline Educação ambiental & UGRH Alto Tietê & $\mathrm{R} \$ 200.000,00$ (FP) \\
Sistema de informação saúde - ambiente & Cotia/ Guarapiranga & $\mathrm{R} \$ 70.000,00$ (FP) \\
Educação ambiental & Billings/ Tamanduateí & $\mathrm{R} \$ 40.000,00$ (FP) \\
Conservação e proteção de mananciais & Juqueri/ Cantareira & $\mathrm{R} \$ 300.000,00$ \\
Recuperação e complementação de rede coletora & Billings/ Tamanduateí & $\mathrm{R} \$ 280.000,00$ \\
Aparelhamento SOS Billings & Billings/ Tamanduateí & $\mathrm{R} \$ 50.000,00$ \\
Coleta seletiva de lixo e reflorestamento de mata ciliar & Cotia/ Guarapiranga & $\mathrm{R} \$ 300.000,00$ \\
\hline
\end{tabular}

Fonte: Deliberação do CBT-AT, nº 03, de 11 de novembro de 1996.

Nota:

Fundo perdido (FP)

Entre estes projetos, o Educação ambiental na represa Billings, Educação ambiental para o Alto Tietê e Sistema de informação saúde - ambiente, foram aprovados e concluídos, além de outros que constam no Anexo C, Quadro 1.

$-\underline{1997}$

Este ano o comitê não se mostrou muito ativo, tendo apenas os seguintes temas relevantes discutidos em suas reuniões: Plano de Macrodrenagem que envolve os rios Tietê e Pinheiros; a Lei de Proteção de Mananciais foi lembrada para que se atentassem sobre a criação das leis específicas para cada manancial; e apresentação do Plano de Desenvolvimento e Proteção Ambiental da Bacia Guarapiranga.

Neste ano iniciou-se a formação dos subcomitês Cotia-Guarapiranga, TietêCabeceiras, Juquerí-Cantareira e Billings-Tamanduateí, os quais iriam articular para a criação das Leis Específicas de Proteção de Mananciais (ALVIM, 2003).

$\mathrm{Na}$ Deliberação 03, realizada em 05 de setembro, foram indicados onze projetos com abrangência em toda a bacia e vinte projetos com abrangência regional para solicitar recursos financeiros do FEHIDRO para execução das atividades. Entre os trinta e um projetos, havia um de canalização e retificação de córrego, um para monitoramento e fiscalização de rios e cinco projetos de educação e conscientização ambiental. Entre os trinta e um projetos 
indicados, dezoito foram pleiteados com os recursos do FEHIDRO, como consta no Anexo C, Quadro 2, estando entre eles os projetos: Educação ambiental em sub-bacias do Pirajuçara, Ação de fiscalização integrada da área de proteção da várzea do Tietê, Diagnóstico ambiental e recomendações para recuperação e exploração do ecoturismo rio São Lourenço e Projeto integrado de educação e saneamento ambiental.

O assunto mais tratado do ano foi a problemática das enchentes na região, sendo colocado em pauta o Plano de Controle de Inundações e o Plano de Macrodrenagem. O objetivo era estudar o sistema de drenagem na bacia do ponto de vista de controle de enchentes e encontrar soluções.

Outro ponto importante discutido foi o Plano Emergencial para as Áreas de Proteção de Mananciais, sendo apresentado o andamento do plano, os problemas de moradias irregulares e debatendo sobre as intervenções necessárias nas moradias que se encontravam em cima ou ao lado dos córregos. Em sua penúltima reunião anual, o Plano Emergencial foi aprovado, sendo ele um dos focos principais nas atividades dos subcomitês neste ano. Dentro da temática de despoluição houve a revisão do Plano Diretor de Esgotos, que passou a incluir a poluição difusa, devido à sua importância em relação a carga poluidora lançada nos rios e córregos.

Neste ano o enquadramento de Programas de Duração Continuada que deveriam ser priorizados no recebimento de recursos do FEHIDRO foi reduzido na Deliberação $n^{\circ}$ 03, de 20 de março, havendo a retirada do programa Serviços e Obras de Proteção e Recuperação da

Qualidade das Águas, mantendo apenas os que envolviam abastecimento, gerenciamento de recursos hídricos e inundações.

A bacia de Taiaçupeba foi pleiteada pela aprovação do projeto "Recuperação e Preservação da Bacia do Taiaçupeba" para recebimento de recursos do FEHIDRO, na Deliberação $\mathrm{n}^{\circ}$ 05, de 08 de junho, tendo contrato durante os anos 2000 a 2002. Outros quarenta e cinco projetos foram aprovados, tendo em sua maioria projetos de educação ambiental (Anexo C, Quadro 3).

Observa-se que houve a continuidade das ações iniciadas nos anos anteriores prevalecendo algumas questões como: o Plano de Macrodrenagem, a criação de leis específicas para mananciais e o Plano Emergencial de Áreas de Proteção de Mananciais.

Houve algumas modificações na priorização de projetos para receber recursos do FEHIDRO, introduzindo os projetos que fomentem não só atividades de recreação e lazer, mas também que sejam compatíveis com a preservação dos recursos hídricos e adicionando os 
projetos que contemplem alternativas de desenvolvimento sustentável em áreas de mananciais. Vinte projetos foram aprovados para receber recursos financeiros, sendo a maioria focados em educação ambiental e saneamento como o projeto de educação ambiental para a região do córrego Rico (Anexo C, Quadro 4).

Sobre as questões de qualidade da água dos corpos hídricos da bacia, destaca-se:

- Proposta de utilizar novos índices de medição da qualidade das águas, inserindo o Índice de Proteção da Vida Aquática (IVA) e o Índice da Qualidade das Águas Brutas (IAP), os quais já estariam sendo adicionados aos próximos relatórios da CETESB.

- A implantação de uma unidade educacional da FEBEM (Fundação Centro de Atendimento Socioeducativo ao Adolescente) na área do Parque Juqueri, em Franco da Rocha. O secretário executivo do subcomitê Juqueri-Cantareira solicitou manifestação do CBH-AT devido aos possíveis impactos nos corpos d'água, em especial no córrego Moendas. ALVIM (2003, p. 336) relata que não houve possibilidade de intervenção, mesmo após deliberação "de caráter indicativo", não sendo esta "considerada pelo Governo do Estado", havendo a instalada da unidade, "demonstrando, de certo modo, a fragilidade política do Comitê".

Neste mesmo ano, foi apresentado o planejamento para construção do Plano de Trabalho dos Recursos Hídricos e do Plano Diretor da Bacia Hidrográfica Alto Tietê, elaborado pela Fundação de apoio à Universidade de São Paulo (FUSP). Organizado pelo CORHI foi desenvolvido por todos os comitês de acordo com prazo estipulado para entrega do material elaborado, tendo como resultado, em 2002, o Plano Estadual de Recursos Hídricos - Relatório de Situação dos Recursos Hídricos do Estado de São Paulo, chamado de Relatório Zero.

A primeira reunião iniciou com informes sobre o andamento da constituição da Fundação Agência de Bacia do Alto Tietê (FABHAT), criada para atuar como braço executivo do $\mathrm{CBH}-\mathrm{AT}$, agindo de forma descentralizada, rápida e eficiente. A FABHAT estava em fase de elaboração, com cronograma aprovado na Deliberação $n^{\circ} 05$, de 21 de junho de 1999.

O ano foi cercado pelas preocupações com a escassez de água na RMSP, abordando a questão do abastecimento em duas reuniões, expondo a situação dos reservatórios, as demandas e disponibilidades de água para os próximos anos e sobre o programa de monitoramento de qualidade de água realizado antes e depois do tratamento para abastecer a região. Além da escassez de água, ocorreu atraso no Plano Emergencial de Áreas de Proteção de Mananciais, sendo justificado pelos problemas financeiros da época.

Os recursos do FEHIDRO foram alocados na Deliberação $n^{\circ}$ 04, de 24 de agosto, sendo $50 \%$ destinado aos projetos de abrangência ou interesse para toda a bacia, 
contemplando a elaboração do mapa de uso e ocupação do solo e atualização da base cartográfica da bacia. Os outros $50 \%$ foram divididos igualmente entre os subcomitês para contemplar programas de educação ambiental, proteção de mananciais e projetos de aproveitamento sustentável dos recursos hídricos. Ao todo, dez projetos foram contemplados (Anexo C, Quadro 5).

Finalizando o ano, foi aprovada em deliberação a "Carta por um Conselho de Gestão Metropolitana" com o objetivo de se criar um espaço de gestão descentralizada para trabalhar de forma integrada com outros setores, sendo possível minimizar os impactos de crescimento urbano e tornar a gestão das cidades mais flexível e menos limitada as políticas rígidas.

Inicialmente, o Plano de Recursos Hídricos da Bacia estava sendo elaborado e foi apresentado seu andamento pela representante da FUSP, Dra. Mônica Porto, expondo na reunião do dia 27 de abril que as principais diretrizes e linhas de ação já haviam sido propostas.

Diante das complicações ocorridas nos anos anteriores e ao recente problema com escassez de água na RMSP, foram feitas duas explanações sobre o abastecimento, abordando as medidas tomadas pela SABESP para minimizar os problemas e reforçar o sistema de abastecimento, detalhando também a situação de falta de chuvas e a produção dos mananciais. A Deliberação $\mathrm{n}^{\circ}$ 01, de 30 de agosto, é outra evidência das preocupações com o abastecimento, tendo como prioritários na classificação de "Serviços e obras de proteção e conservação ambiental" apenas os projetos relacionados com os mananciais da bacia.

Em reunião do dia 30 de agosto, o Secretário do Meio Ambiente, Ricardo Tripoli, fez explanação sobre o projeto de lei que alteraria a Lei $\mathrm{n}^{\circ} 1.172 / 76$, permitindo que os ocupantes das matas ciliares dos mananciais pudessem realizar compensação ambiental dentro da área do manancial, sendo possível a regularização dos imóveis e maior manutenção das áreas vegetadas. A partir disso, o comitê entrega moção ao Presidente da Assembleia Legislativa, com o objetivo de recomendar a regularização da compensação financeira pela utilização dos mananciais. Segundo ALVIM (2003, p. 339-340):

O episódio da alteração da Lei 1.172/76 que institui a proteção aos mananciais na RMSP, para os membros do Comitê e subcomitês, é (...) polêmico. Praticamente todos os trabalhos em andamento nos subcomitês estavam, até então, voltados para a regularização da Nova Lei de Mananciais, a Lei 9.866/97. A atitude da Secretaria do Meio Ambiente, alterando uma legislação que se encontrava desacreditada e em processo de substituição, evidencia importante conflito entre os setores de recursos hídricos e meio ambiente que, até o ano anterior, pareciam articulados. 
Nesta fase, estava sendo muito discutida no comitê a construção de propostas de leis específicas para as APRM, como é observado na reunião do dia 29 de novembro, na qual o presidente do subcomitê Cotia-Guarapiranga explanou sobre a proposta de Lei Específica para a APRM da Guarapiranga.

Além da alteração da Lei de Proteção dos Mananciais, outro tema que mostra a fragilidade do sistema de gestão dos recursos hídricos foi a aprovação anunciada pelo Governo do Estado do Projeto de Flotação no rio Pinheiros sem que o tema tenha passado pelo CBH-AT ou pelo subcomitê Billings-Tamanduateí, surpreendendo os membros do comitê (ALVIM, 2003).

Na Deliberação $\mathrm{n}^{\circ}$ 03, de 30 de agosto, o comitê autorizou a suplementação de recursos do FEHIDRO para o projeto de atualização da base cartográfica da RMSP. Não houve deliberação com indicação de projetos a serem financiados com recursos do FEHIDRO e não foram encontrados dados de projetos contemplados durante este ano.

Neste ano ocorreram apenas três reuniões, estando entre os temas debatidos: os recursos financeiros do FEHIDRO, o rebaixamento da calha do rio Tietê e o andamento dos Planos de Desenvolvimento e Proteção Ambiental (PDPA's), desenvolvidos desde 1999 para a Guarapiranga, Billings, Alto Tietê e Sistema Cantareira.

Mais uma vez evidenciou-se a falta de comunicação entre os setores públicos com o comitê, na reunião de 17 de setembro, sendo questionada pelo prefeito de Santana de Paraíba, Sr. Silvio Pecciolo, a aprovação da Licença Ambiental de Instalação para o rebaixamento da calha do rio Tietê, sem que antes houvesse a explanação às prefeituras de Santana de Parnaíba e de Pirapora do Bom Jesus, além do comitê sobre o assunto. A segunda fase do projeto de rebaixamento da calha do rio Tietê havia sido apresentada pelo representante do DAEE, Dr. Ricardo Borsari, na reunião de 29 de novembro de 2001. O mesmo esclareceu após o questionamento que foram feitas audiências públicas e adotadas medidas mitigadoras, sendo um processo de licitação acompanhado pelo DAEE.

A Deliberação $\mathrm{n}^{\circ}$ 01, de 19 de abril, homologou os pedidos de financiamento com recursos do FEHIDRO, estando entre eles os projetos do Quadro 6. Houve projetos contemplados muito significativos para a recuperação/ preservação dos corpos hídricos como programas de educação ambiental, saneamento e mídia ambiental (Anexo C, Quadro 6). 
Quadro 6 - Lista de alguns projetos indicados para recebimento de recursos financeiros do FEHIDRO no ano 2002 com recursos de 2001.

\begin{tabular}{|c|c|c|}
\hline Projeto & $\begin{array}{c}\text { Subcomitê atendido } \\
\text { com recurso }\end{array}$ & Investimento* \\
\hline Coleta seletiva e reciclagem & Tietê-Cabeceiras & $\mathrm{R} \$ 87.500,00$ \\
\hline Saneamento da microbacia do Ribeirão Peroba & Tietê-Cabeceiras & $\mathrm{R} \$ 97.751,00$ \\
\hline Recomposição da mata ciliar do rio Tietê & Tietê-Cabeceiras & $\mathrm{R} \$ 104.886,00$ \\
\hline "Água Vida" - Projeto regional de educação ambiental & Juqueri-Cantareira & $\mathrm{R} \$ 234.806,00$ \\
\hline $\begin{array}{l}\text { Implantação e recuperação de mata nativa em } \\
\text { Mairiporã }\end{array}$ & Juqueri-Cantareira & $\mathrm{R} \$ 179.685,00$ \\
\hline Renascer da Cantareira & Juqueri-Cantareira & $\mathrm{R} \$ 30.910,00$ \\
\hline "SABESP - Educando para a cidadania" & Cotia-Guarapiranga & $\mathrm{R} \$ 87.500,00$ \\
\hline Apoio técnico ao gerenciamento de bacias & Billings-Tamanduateí & $\mathrm{R} \$ 142.500,00$ \\
\hline Programa de educação para o ambiente & Billings-Tamanduateí & $\mathrm{R} \$ 97.500,00$ \\
\hline Comunicação social e educação ambiental & Pinheiros-Pirapora & $\mathrm{R} \$ 100.000,00$ \\
\hline
\end{tabular}

Fonte: Deliberação do CBT-AT, n 01 , de 19 de abril de 2002.

Nota:

* Soma do Valor Financiado e do Valor de Contrapartida.

Em seguida, na Deliberação $\mathrm{n}^{\circ}$ 03, a partir das instruções normativas da ANA referente ao Programa de Despoluição de Bacias Hidrográficas (PRODES), o comitê montou lista de projetos por ordem de prioridade, havendo dez projetos na lista. O PRODES é um programa criado pela ANA, em 2001, pela resolução $n^{\circ}$ 006, para reduzir o índice de esgoto urbano não tratado, diminuindo a poluição nas bacias hidrográficas. Desta forma, ocorre a concessão do financiamento em forma de pagamento por esgoto tratado para prestadores de serviço de saneamento, incentivando a instalação de estações de tratamento de esgoto (ANA, 2015).

Novamente o rebaixamento da calha do rio Tietê entra em discussão. A presidente do comitê, Sra. Marta Suplicy, explanou sobre as consequências que estavam sendo observadas com a obra. Sua função principal era diminuir as inundações na RMSP, porém as cidades localizadas a jusante, na bacia do Médio Tietê, sofreram com as cargas poluidoras que foram 
levantadas do fundo do rio. Na mesma reunião foi confirmado que haviam atingido 61 a $62 \%$ de esgoto tratado na RMSP. A implantação do esgoto fazia (faz) parte do Projeto de Despoluição do rio Tietê.

Na Deliberação $n^{\circ}$ 07, de 30 de junho, são homologados os pedidos de financiamento com recursos do FEHIDRO para projetos da bacia (Quadro 7).

Quadro 7 - Lista de alguns projetos indicados para recebimento de recursos financeiros do FEHIDRO do ano 2003.

\begin{tabular}{|c|c|c|}
\hline Projeto & $\begin{array}{c}\begin{array}{c}\text { Subcomitê atendido } \\
\text { com recurso }\end{array} \\
\end{array}$ & Investimento* \\
\hline "Detecção de Áreas Possíveis de Invasão" & CBH-AT & $\mathrm{R} \$ 91.250,00$ \\
\hline "Educação Ambiental no Núcleo Águas Claras" & Juqueri-Cantareira & $\mathrm{R} \$ 101.250,00$ \\
\hline $\begin{array}{lcccc}\text { "Patrulha Especial de Proteção } & \text { Ambiental } & \text { - } \\
\text { fiscalização como Instrumento de Prevenção } & \text { e } \\
\text { Repressão das Degradações nos Recursos Hídricos" }\end{array}$ & Juqueri-Cantareira & $\mathrm{R} \$ 197.700,00$ \\
\hline $\begin{array}{l}\text { "Ensino Sistematizado de Proteção a Natureza, } \\
\text { Educação Ambiental como Alavanca para a } \\
\text { Recuperação das Áreas de Mananciais e dos Recursos } \\
\text { Hídricos" }\end{array}$ & Juqueri-Cantareira & $\mathrm{R} \$ 136.220,00$ \\
\hline "O Rio pelos Trilhos" & Juqueri-Cantareira & $\mathrm{R} \$ 123.849,80$ \\
\hline $\begin{array}{l}\text { "Projeto Nascente: Fortalecimento da Educação } \\
\text { Ambiental da Nascente do Tietê" }\end{array}$ & Alto Tietê-Cabeceiras & $\mathrm{R} \$ 81.241,25$ \\
\hline "Saneamento da Microbacia do Ribeirão Peroba" & Alto Tietê-Cabeceiras & $\mathrm{R} \$ 125.860,25$ \\
\hline $\begin{array}{l}\text { "Ensino Sistematizado de Proteção a Natureza - } \\
\text { Educação Ambiental" }\end{array}$ & Alto Tietê-Cabeceiras & $\mathrm{R} \$ 100.000,00$ \\
\hline $\begin{array}{l}\text { "Recuperação e Preservação de Recursos Hídricos da } \\
\text { Micro Bacia do São José" }\end{array}$ & Cotia-Guarapiranga & $\mathrm{R} \$ 97.500,00$ \\
\hline $\begin{array}{l}\text { "Proteção Integrada na área do Subcomitê Cotia- } \\
\text { Guarapiranga" }\end{array}$ & Cotia-Guarapiranga & $\mathrm{R} \$ 100.000,00$ \\
\hline "Fiscalização e Educação Ambiental" & Cotia-Guarapiranga & $\mathrm{R} \$ 75.000,00$ \\
\hline $\begin{array}{l}\text { "Diagnóstico Preliminar da Qualidade Ambiental da } \\
\text { Bacia Hidrográfica do Rio Guaió" }\end{array}$ & Billings-Tamanduateí & $\mathrm{R} \$ 100.000,00$ \\
\hline
\end{tabular}

Fonte: Deliberação do CBT-AT, nº 01, de 30 de junho de 2003.

Nota:

* Soma do Valor Financiado e do Valor de Contrapartida. 
Dos projetos citados acima, sete foram contemplados com recursos do FEHIDRO, além de outros dezoito (Anexo C, Quadro 7).

O abastecimento da RMSP foi o tópico mais abordado ao longo do ano. Isto porque foi permitida a retirada de até $31 \mathrm{~m}^{3} / \mathrm{s}$ de água da bacia dos rios Piracicaba, Capivari e Jundiaí (PCJ) para abastecer a RMSP. Esta decisão foi baseada na criticidade vivida pela RMSP na época pela falta de disponibilidade hídrica. Outro tema discutido foi a elaboração das leis especificas para os mananciais, priorizando os projetos que visavam tal elaboração.

As novas regras para solicitação de recursos financeiros do FEHIDRO desconsideram os empreendimentos do ano anterior que não possuam contrato assinado. A partir da deliberação do COFEHIDRO com lista de empreendimentos que foram desconsiderados, o CBH-AT realizou deliberação para não só dividir o recurso financeiro do comitê, mas também para homologar os pedidos que haviam sido descartados pelo COFEHIDRO, tendo nesta lista quatorze projetos, não apenas de 2003, mas também de dos anos 1999, 2000 e 2002 que até então não haviam conseguido contrato para receber o recurso. Alguns projetos importantes para a recuperação/ proteção dos corpos d'água estavam inclusos na lista:

Quadro 8 - Lista de alguns projetos desconsiderados pelo COFEHIDRO e homologados para o exercício de 2004.

\begin{tabular}{|c|c|c|c|}
\hline Projeto & Ano & $\begin{array}{c}\text { Subcomitê atendido } \\
\text { com recurso }\end{array}$ & Investimento* \\
\hline Detecção de áreas possíveis de invasão & 2003 & CBH-AT & $\mathrm{R} \$ 91.750,00$ \\
\hline $\begin{array}{l}\text { Interpretação e análise do uso do solo em } \\
2003 \text { na bacia hidrográfica Billings- } \\
\text { Tamanduateí }\end{array}$ & 2003 & $\begin{array}{l}\text { Billings- } \\
\text { Tamanduateí }\end{array}$ & $\mathrm{R} \$ 50.000,00$ \\
\hline $\begin{array}{l}\text { Fundamentos ecotoxicologia aquática para } \\
\text { utilização em educação ambiental }\end{array}$ & 2000 & Cotia-Guarapiranga & $\mathrm{R} \$ 39.057,50$ \\
\hline $\begin{array}{l}\text { Projeto de recuperação e preservação dos } \\
\text { recursos hídricos da microbacia do rio São } \\
\text { José }\end{array}$ & 2003 & Cotia-Guarapiranga & $\mathrm{R} \$ 336.790,03$ \\
\hline $\begin{array}{l}\text { Projeto educação sanitária ambiental / } \\
\text { incentivo fossa séptica no município de } \\
\text { Francisco Morato }\end{array}$ & 2003 & Juqueri-Cantareira & $\mathrm{R} \$ 37.605,00$ \\
\hline $\begin{array}{l}\text { Projeto educação sanitária ambiental / } \\
\text { incentivo fossa séptica no município de } \\
\text { Franco da Rocha }\end{array}$ & 2003 & Juqueri-Cantareira & $\mathrm{R} \$ 37.605,00$ \\
\hline
\end{tabular}


Quadro 9 - Lista de alguns projetos desconsiderados pelo COFEHIDRO e homologados para o exercício de 2004.

Continuação

\begin{tabular}{lccc}
\hline \multicolumn{1}{c}{ Projeto } & Ano & $\begin{array}{c}\text { Subcomitê atendido } \\
\text { com recurso }\end{array}$ & Investimento \\
\hline $\begin{array}{l}\text { Educação ambiental no núcleo Águas Claras } \\
\begin{array}{l}\text { Programa de educação ambiental no Parque } \\
\text { Chico Mendes }\end{array}\end{array}$ & 2003 & Juqueri-Cantareira & $\mathrm{R} \$ 101.250,00$ \\
\hline
\end{tabular}

Fonte: Deliberação do CBT-AT, n 01 , de 19 de fevereiro de 2004.

Nota:

* Soma do Valor Financiado e do Valor de Contrapartida.

Os projetos de incentivo à utilização de fossa séptica em localidades com alto índice de moradias irregulares mostram a necessidade de adotar medidas de saneamento e a incapacidade de contemplar aquela população com os serviços básicos de saneamento urbano. Apenas o "Interpretação e análise do uso do solo em 2003 na bacia hidrográfica BillingsTamanduateí" constava na lista de empreendimentos com contrato para recebimento de recursos entre os projetos que se inscreveram no ano.

$\mathrm{Na}$ segunda deliberação do comitê, foi decidido que os recursos que seriam encaminhados para os projetos que foram desconsiderados pelo COFEHIDRO, seriam encaminhados aos colegiados de origem dos empreendimentos, havendo vinte e sete projetos nesta lista.

Já na Deliberação $n^{\circ} 4$, de 7 de maio, sessenta empreendimentos foram indicados pelo comitê e na Deliberação $n^{\circ} 6$ de 29 de junho, outros três projetos foram indicados, levando-se em consideração os recursos financeiros excedentes do ano: "Valorização econômica dos serviços ambientais prestados pelas áreas florestais da bacia da represa Billings", "Juca Vivo - capacita subcomitê" e "O rio pelos trilhos", tendo estes sido aprovados pelo FEHIDRO.

No total, quarenta e nove projetos que haviam sido indicados foram aprovados pelo FEHIDRO (Anexo C, Quadro 8).

Com apenas quatro reuniões ao longo do ano, o comitê discutiu sobre a necessidade de priorizar a atualização do plano da bacia. Sobre o Projeto Tietê, o presidente da Agência da Bacia Alto Tietê, Dr. Júlio Cerqueira César, expos a necessidade de avanços no aumento da 
rede de esgotos, pois diante dos lançamentos de esgoto "in natura" o projeto não teria avanços, entregando no final o rio Tietê nas mesmas condições do início do projeto, adicionou ainda, que os estudos da Agência buscavam aprofundar o conhecimento sobre a qualidade das águas superficiais com enfoque ambiental e de saneamento.

Na Deliberação $\mathrm{n}^{\circ}$ 3, de 27 de julho, foram indicados trinta e cinco projetos para serem financiados com recursos do FEHIDRO, estando entre eles:

Quadro 10 - Lista de alguns projetos indicados para recebimento de recursos financeiros do FEHIDRO do ano 2005.

\begin{tabular}{lcc}
\hline \multicolumn{1}{c}{ Projeto } & $\begin{array}{c}\text { Subcomitê atendido } \\
\text { com recurso }\end{array}$ & Investimento* \\
\hline $\begin{array}{l}\text { Cidadania e educação ambiental na área de recursos } \\
\text { hídricos }\end{array}$ & CBH-AT & $\mathrm{R} \$ 313.522,00$ \\
$\begin{array}{l}\text { PROLIMPE - Programa de Limpeza Emergencial de } \\
\text { Rios e Córregos }\end{array}$ & CBH-AT & $\mathrm{R} \$ 880.000,00$ \\
$\begin{array}{l}\text { Canalização de trecho do córrego Itaim } \\
\text { Saneamento da microbacia do Ribeirão Peroba }\end{array}$ & Tietê-Cabeceiras & $\mathrm{R} \$ 236.889,93$ \\
$\begin{array}{l}\text { Adequação de aterro sanitário } \\
\text { Projeto de educação para a receiras } \\
\text { sustentado da várzea de Rio Grande da Serra }\end{array}$ & $\mathrm{R} \$ 121.572,53$ \\
$\begin{array}{l}\text { Projeto recuperar para preservar } \\
\text { Projeto gestão ambiental participativa "Conexão água" }\end{array}$ & Pinheiros-Pirapora & $\mathrm{R} \$ 204.396,38$ \\
\begin{tabular}{l} 
Protetores da água \\
\hline
\end{tabular} & Cotia-Guarapiranga & $\mathrm{R} \$ 68.160,00$ \\
\end{tabular}

Fonte: Deliberação do CBT-AT, n 3, de 27 de julho de 2005.

Nota:

* Soma do Valor Financiado e do Valor de Contrapartida.

Entre os projetos do Quadro 9, cinco foram aprovados, como o PROLIMPE, além do "Revitalização do córrego Bussocaba" em Osasco e projetos de educação ambiental (Anexo C, Quadro 9). 
$\mathrm{Na}$ segunda reunião do ano, o representante da Secretaria do Verde e do Meio Ambiente, Sr. Gilmar Altamira, abordou o tema dos rios urbanos, colocando em pauta as questões sobre qualidade das águas, as enchentes e a visão que a população tem dos rios devido à sua degradação.

Em sua última reunião, houve mais um caso de falta de comunicação entre os órgãos públicos e o $\mathrm{CBH}-\mathrm{AT}$, pois o $\mathrm{CBH}-\mathrm{AT}$ não havia sido informado e não participou das discussões sobre a criação da Lei Específica para a Guarapiranga. Ocorreu ainda a colocação de que o comitê e suas câmaras técnicas não eram responsáveis pela proposta de leis específicas, deixando diversos membros estarrecidos após terem trabalhado em cima do tema.

Esta não foi a única situação de divergências no comitê, em 2003 o CBH-AT havia rejeitado o EIA/RIMA* das obras do Rodoanel. Entretanto não houve continuação, não havendo propostas de alternativas que pudessem causar menor impacto nas áreas de mananciais, sendo o EIA/RIMA e a Licença Prévia aprovados pelo Conselho Estadual de Meio Ambiente (CONSEMA) em 2006, sem qualquer colaboração de melhorias do CBH-AT.

Houve cinquenta e um projetos indicados para recebimento de recursos financeiros e nove projetos suplentes na Deliberação $\mathrm{n}^{\circ} 6$, de 29 de junho. Os projetos suplentes começaram a ser indicados no ano 2005.

Observa-se o crescimento nos números de projetos aprovados pelo FEHIDRO que tratam sobre educação ambiental e resíduos sólidos, principalmente sobre coleta seletiva e formação ou treinamento de professores e agentes de educação ambiental.

Diante das ocorrências de divergências entre o CBH-AT e outras entidades, como especificado anteriormente, uma representante da Secretaria do Meio Ambiente foi ao comitê na segunda reunião do ano e informou que a secretaria havia composto um Grupo de Trabalho para discutir a elaboração da Lei Específica da Billings, convidando os membros do comitê para participar do GT, caso quisessem.

Como o FEHIDRO informou que haveriam alterações na fórmula para escolha de projetos contemplados, o CBH-AT solicitou que não houvesse mudanças neste ano para que o assunto pudesse ser discutido. Desta forma, não houve indicação de projetos, não havendo inscrição de empreendimentos para serem contemplados.

\footnotetext{
EIA/RIMA é um instrumento da Política Nacional do Meio Ambiente que realiza Avaliação de Impacto Ambiental de empreendimentos analisando seu uso e implantação, sendo EIA: Estudo de Impacto Ambiental e RIMA: Relatório de Impacto Ambiental (Resolução CONAMA $n^{\circ}$ 001, de 23 de janeiro de 1986).
} 
Já as deliberações realizadas foram divididas entre trâmites internos do CBH-AT (como eleições, Câmaras Técnicas e Estatuto do CBH-AT), as Leis Específicas de APRM's (Guarapiranga, Alto Juquery e Billings) e uma deliberação de aprovação da implantação de cobrança pelo uso de água da BH-AT (Anexo B, Quadro 14).

A segunda reunião do comitê foi extremamente significativa, voltando a ter cunho mais informativo sobre projetos, propostas e questões a serem resolvidas. Foi discutido não apenas sobre as alterações nos critérios de escolha de projetos para serem pleiteados com recursos do FEHIDRO, mas também houve colocações de membros com críticas sobre melhorias necessárias e informes sobre projetos, destacando-se:

- Necessidade de avanços sobre classificação e enquadramento dos corpos hídricos;

- Falta de aplicabilidade sobre assuntos tratados na Câmara Técnica de Águas Subterrâneas; e

- Tratativa do Programa Córrego Limpo (Resumo Executivo da Ata $n^{\circ}$ 2, de 28 de março, p. 6):

(...) de certa maneira no Comitê temos discutido os efeitos e não as causas, ficamos preocupados com a poluição do rio Tietê, da Guarapiranga, do entorno, quando o município é o principal poluidor porque todos esses córregos chegam aos nossos mananciais via o lixo produzido por essa cidade de dez milhões de habitantes. Estamos lutando para que esse programa Córrego Limpo não seja um programa de governo mas de política pública, que possa perenizar independente das questões da troca de governo ou não nas próximas eleições, então estou fazendo uma moção para que esse Comitê se preocupe com esse Programa de fundamental importância, para que $30 \%$ da carga de esgoto que vão aos nossos mananciais, para constar que esse modelo do programa Córrego Limpo seja incorporado nesse modelo de gestão do corpo hídrico para que não seja apenas um programa de governo mas que seja perene e que tenha a ação da sociedade como um todo nesse Comitê, e a tendência até é que esse programa possa abranger com o tempo 100 córregos, e sem isso não vamos conseguir proteger nossos mananciais se a sujeira produzida em São Paulo não for gerenciada, tanto pela forma não estruturante como estruturante. (Representante da Prefeitura Municipal de São Paulo, Sr. Gilmar Altamirano)

Como consequência das reuniões conduzidas de forma mais ampla, a Câmara Técnica de Saneamento Ambiental enviou proposta sobre o reenquadramento dos corpos hídricos para ser adicionado ao Plano da Bacia e o Programa Córrego Limpo tomou maior visibilidade, sendo considerado importante pela Câmara Técnica. 
A Deliberação $\mathrm{n}^{\circ} 1$, de 28 de janeiro, especifica não só os critérios e hierarquização dos empreendimentos a serem financiados com recursos do FEHIDRO, como insere lista de linhas prioritárias do CBH-AT e a demanda os subcomitês de acordo com essas linhas. Os projetos passaram a ser separados em demandas "induzidas" com projetos que surgissem a partir do CBH-AT, os quais necessitariam de deliberação específica e "espontâneas" abarcando todos os demais que estejam inclusos em uma das linhas:

a) PDPA e Leis Específicas;

b) Operacionalização da Lei nº12.233/06 (define a APRM da bacia do Guarapiranga);

c) Saneamento e recuperação ambiental;

d) Saneamento e recuperação de mananciais;

e) Controle e fiscalização em áreas de mananciais;

f) Ferramentas de Gestão de Recursos Hídricos, inclusive uso racional da água;

g) Sistemas de Informações Gerenciais;

h) Estratégia para a implementação da cobrança pelo uso da água;

i) Sistema de Comunicação Integrado;

j) Educação Ambiental

A educação ambiental ficou por último na lista, porém pode ser vinculada a qualquer linha prioritária sendo caracterizada como de maior importância. A maioria os subcomitês, com exceção do Juquery-Cantareira (que elencou inicialmente os sistemas de drenagem) e Cotia-Guarapiranga, elencaram o saneamento ambiental como de maior prioridade. Os subcomitês Billings-Tamanduateí, Cotia-Guarapiranga e Pinheiros-Pirapora adicionaram os projetos de "conservação e revitalização de corpos hídricos" como uma das linhas prioritárias, sendo a primeira da lista de prioridades do subcomitê Cotia-Guarapiranga.

Entretanto, na lista de projetos indicados, na Deliberação $n^{\circ} 4$, de 31 de março, havia apenas um que tratava diretamente sobre conservação e recuperação de recursos hídricos. $\mathrm{E}$ um projeto com o tema "Educação Sanitária e Ambiental sobre disposição adequada de Esgotos Domésticos “ na Deliberação n ${ }^{\circ} 7$, de 26 de maio.

Os dados de projetos aprovados pelo FEHIDRO, indicam que houve contrato assinado com trinta projetos, destacando-se o "Proteção da margem direita do córrego da Av. Campo Grande, bairro Nova Poá" e "Despoluição de óleo vegetal na bacia do Tietê-Cabeceiras", encontrando-se o segundo em fase de execução.

$-\underline{2009}$

Neste ano foram apresentados problemas com os empreendimentos aprovados, havendo projetos não iniciados, outros com atraso de mais de dois anos e ainda alguns que não haviam prestado contas da última parcela recebida de recurso financeiro.

$\mathrm{Na}$ Deliberação $\mathrm{n}^{\circ} 1$, de 12 de janeiro, foram definidas novamente as linhas prioritárias induzidas de empreendimentos e as linhas prioritárias para cada subcomitê, 
colocando o Plano de Bacia em evidência. O Subcomitê Cotia-Guarapiranga manteve "conservação e revitalização de corpos hídricos" em primeiro lugar.

Foram indicados 40 projetos distribuídos entre demanda induzida do CBHA-AT e do CRH, espontânea e banco de projeto do CBH-AT:

Quadro 11 - Lista de alguns projetos indicados para recebimento de recursos financeiros do FEHIDRO do ano 2009.

\begin{tabular}{|c|c|c|}
\hline Projeto & Tomador & Investimento* \\
\hline $\begin{array}{l}\text { Projeto Minha Nascente - Revitalização dos } \\
\text { corpos d'água na Bacia do Tietê-Cabeceiras }\end{array}$ & Organização Bio-Bras & $\mathrm{R} \$ 172.930,00$ \\
\hline $\begin{array}{l}\text { Programa de Educação Ambiental: comunicação } \\
\text { social e capacitação socioambiental voltada à } \\
\text { gestão dos recursos hídricos na Bacia do Alto } \\
\text { Tietê }\end{array}$ & $\begin{array}{l}\text { Cooperativa de Serviços e } \\
\text { Pesquisas Tecnológicas e } \\
\text { Industriais }\end{array}$ & $\mathrm{R} \$ 136.300,00$ \\
\hline Projeto Barco-Escola ABC das Águas & $\begin{array}{l}\text { Cidadania, Saúde, Trabalho, } \\
\text { Educação e Meio } \\
\text { Associação Global de }\end{array}$ & $\mathrm{R} \$ 170.122,00$ \\
\hline $\begin{array}{l}\text { Gestão Sustentável do Meio Ambiente e dos } \\
\text { Recursos Hídricos }\end{array}$ & Desenvolvimento Sustentado & $\mathrm{R} \$ 302.006,64$ \\
\hline Implantação de nova travessia no rio Paraitinga & $\begin{array}{l}\text { Prefeitura da Estância } \\
\text { Turística de Salesópolis }\end{array}$ & $\mathrm{R} \$ 270.726,12$ \\
\hline Parque linear ecológico Jaguari & $\begin{array}{l}\text { Prefeitura Municipal de } \\
\text { Suzano }\end{array}$ & $\mathrm{R} \$ 1.092 .425,53$ \\
\hline $\begin{array}{l}\text { "De olho no óleo - despoluindo os recursos } \\
\text { hídricos e transformando resíduo em fonte de } \\
\text { energia" }\end{array}$ & $\begin{array}{l}\text { Prefeitura Municipal de } \\
\text { Osasco }\end{array}$ & $\mathrm{R} \$ 299.529,00$ \\
\hline $\begin{array}{l}\text { Redescobrindo e despoluindo os córregos do seu } \\
\text { bairro - "Apoio ao Programa Córrego Limpo - } \\
\text { SABESP" }\end{array}$ & Universidade da Água & $\mathrm{R} \$ 238.680,00$ \\
\hline
\end{tabular}

Fonte: Deliberação do CBT-AT, n ${ }^{\circ}$, de 20 de julho de 2009.

Nota:

* Soma do Valor Financiado e do Valor de Contrapartida.

Quarenta projetos foram aprovados para receber recursos do FEHIDRO, destacando-se os projetos:

- Projeto minha nascente - Revitalização dos corpos d'água na bacia do Alto TietêCabeceiras; 
- Projeto gestão sustentável do meio ambiente e dos recursos hídricos;

- De olho no óleo - despoluindo os recursos hídricos e transformando resíduos em fonte de energia; e

- Programa de conservação e proteção de corpos hídricos - nascentes do Guarapiranga.

As obras do Rodoanel na cidade de Guarulhos causaram problemas e não cumpriram com o determinado pelas avaliações técnicas, havendo muita discussão sobre o assunto no comitê. O projeto de monitoramento da quantidade e qualidade das águas do rio Juquery obtive destaque, sendo solicitado para que a prefeitura de Cajamar mantivesse o projeto que já havia beneficiado cinco municípios da sub-bacia Juquery-Cantareira, resultando na proposta da prefeitura auxiliar nos estudos para o enquadramento dos corpos hídricos, conforme previsto no Plano de Bacia do Alto Tietê.

Foram indicados trinta projetos para recebimento de recursos financeiros do FEHIDRO, sendo vinte e oito listados na Deliberação $n^{\circ} 3$ e dois na Deliberação $\mathrm{n}^{\circ} 5$. Dezoito foram contemplados, ficando em evidência a quantidade de projetos sobre uso racional da água.

A renovação da gestão do $\mathrm{CBH}-\mathrm{AT}$ trouxe mudanças positivas na tratativa do comitê com a sociedade civil, incentivando que fossem desenvolvidos mais projetos que favorecessem a população e buscando maior visibilidade como, por exemplo, garantir acesso às informações atualizadas, com qualidade e de fácil acesso, promovendo a criação de Grupo de Trabalho para construção do site do comitê. Além dessa mudança, constituiu-se colegiado composto pela diretoria dos subcomitês e do comitê para que houvesse maior articulação, deixando de centralizar os assuntos nos subcomitês e promovendo maior envolvimento entre os membros.

Ao longo do ano ocorreram três deliberações com indicação de projetos para receber recursos financeiros, sendo indicados trinta e cinco empreendimentos, destacando-se: 
Quadro 12 - Lista de alguns projetos indicados para recebimento de recursos financeiros do FEHIDRO do ano 2011.

\begin{tabular}{|c|c|c|}
\hline Projeto & Tomador & Investimento* \\
\hline $\begin{array}{l}\text { Plano de Manejo da APA Embu Verde - } \\
\text { Zoneamento Ambiental Participativo na Bacia do } \\
\text { Rio Cotia }\end{array}$ & $\begin{array}{l}\text { Prefeitura Municipal de Embu } \\
\text { das Artes }\end{array}$ & $\mathrm{R} \$ 337.100,40$ \\
\hline $\begin{array}{l}\text { Recuperação de área degradada pelas ações } \\
\text { antrópicas e as fortes chuvas e a resultante erosão }\end{array}$ & $\begin{array}{l}\text { Prefeitura Municipal de } \\
\text { Diadema }\end{array}$ & $\mathrm{R} \$ 460.139,56$ \\
\hline $\begin{array}{l}\text { Educação Ambiental através da percepção da água } \\
\text { na paisagem urbana }\end{array}$ & $\begin{array}{l}\text { Prefeitura Municipal de São } \\
\text { Paulo }\end{array}$ & $\mathrm{R} \$ 250.000,00$ \\
\hline Mairiporã - Água e socioambiente & Associação Terceira Via & $\mathrm{R} \$ 351.716,41$ \\
\hline $\begin{array}{l}\text { Construindo estratégias para o desenvolvimento } \\
\text { das áreas do manancial Billings com } \\
\text { sustentabilidade: formação de lideranças } \\
\text { comunitárias }\end{array}$ & $\begin{array}{c}\text { Associação Natureza Sempre } \\
\text { Natural }\end{array}$ & $\mathrm{R} \$ 379.031,70$ \\
\hline $\begin{array}{l}\text { Rio do Nosso Lugar: Conhecendo e cuidando dos } \\
\text { recursos hídricos do Alto Tietê Cabeceiras }\end{array}$ & $\begin{array}{l}\text { Associação Aliança Libertária } \\
\text { Meio Ambiente - ALMA }\end{array}$ & $\mathrm{R} \$ 504.558,00$ \\
\hline 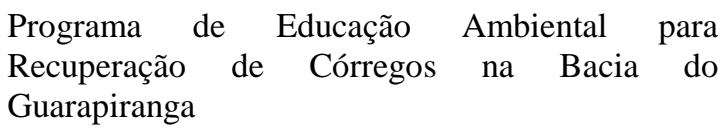 & $\begin{array}{l}\text { Prefeitura Municipal de } \\
\text { Itapecerica da Serra }\end{array}$ & $\mathrm{R} \$ 139.115,85$ \\
\hline Caieiras e suas Nascentes & $\begin{array}{l}\text { Prefeitura Municipal de } \\
\text { Caieiras }\end{array}$ & $\mathrm{R} \$ 429.337,00$ \\
\hline $\begin{array}{l}\text { Estudo de correlação entre o uso e ocupação do } \\
\text { solo com a qualidade da água superficial na Bacia } \\
\text { Hidrográfica do rio Baquirivu Guaçu, municípios } \\
\text { de Guarulhos e Arujá }\end{array}$ & $\begin{array}{l}\text { Prefeitura Municipal de } \\
\text { Guarulhos }\end{array}$ & $\mathrm{R} \$ 729.150,00$ \\
\hline $\begin{array}{l}\text { Revitalização das nascentes do rio Tamanduateí e } \\
\text { recomposição das áreas degradadas no Parque da } \\
\text { Gruta de Santa Luzia e outras APP's no município }\end{array}$ & Prefeitura Municipal de Mauá & $\mathrm{R} \$ 1.272 .705,72$ \\
\hline $\begin{array}{l}\text { Identificação e hierarquização de áreas de } \\
\text { degradação física de corpos hídricos de Osasco e } \\
\text { implantação de ações iniciais de recuperação, } \\
\text { minimização de risco de enchentes envolvendo a } \\
\text { educação patrimonial }\end{array}$ & $\begin{array}{l}\text { Prefeitura Municipal de } \\
\text { Osasco }\end{array}$ & $\mathrm{R} \$ 1.209 .710,00$ \\
\hline
\end{tabular}

Fonte: Deliberação do CBT-AT, $\mathrm{n}^{\circ} 13$, de 30 de junho de $2011 ; \mathrm{n}^{\circ} 16$, de 06 de outubro de 2011; e $\mathrm{n}^{\circ} 18$, de 14 de dezembro de 2011.

Nota:

* Soma do Valor Financiado e do Valor de Contrapartida. 
De acordo com dados do FEHIDRO, dez projetos foram contemplados, estando entre eles "Rios do nosso lugar: conhecendo e cuidando dos recursos hídricos do Alto TietêCabeceiras" e "Mairiporã - água e socioambiente".

Para este ano, a análise embasada na leitura das atas e identificação dos pontos relevantes à pesquisa foi prejudicada por falta de todas as atas do comitê. Após acesso em sites e contato por telefone e e-mail diretamente com o CBH-AT, não foi possível obter todos os registros, após alegação do próprio comitê de que possuíam apenas o Resumo Executivo da ATA Plenária Extraordinária de 12 de março.

Foram indicados no total vinte e um projetos na Deliberação $n^{\circ} 6$, tendo apenas dois empreendimentos aprovados pelo FEHIDRO (Anexo C, Quadro 15).

Quadro 13 - Lista de alguns projetos indicados para recebimento de recursos financeiros do FEHIDRO do ano 2012.

\begin{tabular}{lcc}
\hline Projeto & Tomador & Investimento* $^{*}$ \\
\hline $\begin{array}{l}\text { Proposta de Ação para recuperação de áreas } \\
\text { urbanas e ambientais degradadas - SisAD }\end{array}$ & UNIÁGUA & $\mathrm{R} \$ 797.672,00$ \\
$\begin{array}{l}\text { Identificação e hierarquização de áreas de } \\
\text { degradação física de corpos hídricos de Osasco e } \\
\text { implantação de ações iniciais de recuperação, } \\
\text { minimização de risco de enchentes envolvendo a } \\
\text { educação patrimonial }\end{array}$ & $\begin{array}{c}\text { Prefeitura Municipal de } \\
\text { Osasco }\end{array}$ & $\mathrm{R} \$ 1.209 .710,00$ \\
\hline
\end{tabular}

Fonte: Deliberação do CBT-AT, ${ }^{\circ}$ 6, de 28 de novembro de 2012.

Nota:

* Soma do Valor Financiado e do Valor de Contrapartida.

As leis específicas de mananciais, que até então eram priorizadas, foram deixadas de lado, havendo necessidade do comitê intervir junto à ALESP para dar continuidade na Lei Específica Juquery-Cantareira, texto elaborado pelo subcomitê, que estava a dois anos parada para análise.

Apenas nove projetos foram indicados na Deliberação $n^{\circ} 14$, de 1 de outubro, e cinco foram contemplados, não havendo nenhum projeto aprovado que tratasse diretamente dos 
corpos hídricos, havendo três de cunho de pesquisa: "Avaliação de indicações, proposta de novos critérios de hierarquização e sistema de acompanhamento da execução dos empreendimentos FEHIDRO", "Plano da BH-AT" e "Mapeamento sistemático e temático de uso e ocupação do solo, da BH-AT e da RMSP”.

Observou-se que neste ano ocorreu o acompanhamento dos subcomitês, Câmaras Técnicas e Grupos de Trabalho, incluindo nos informes atualização sobre os trabalhos realizados, promovendo maior integração entre os membros do comitê com os outros grupos.

Os tópicos dos problemas de escassez hídrica na RMSP tornaram-se a base das discussões do comitê, abordando principalmente as ações realizadas e propostas para minimizar o consumo e as perdas de água. O Plano da Bacia estava em início de desenvolvimento, bem como a abertura de licitações para contratação de empresas para desenvolvê-lo.

Apenas nove projetos foram indicados na Deliberação $n^{\circ} 4$, de 23 de setembro, para recebimento de recursos financeiros do FEHIDRO, sendo dois projetos sobre macrodrenagem, três sobre redução do consumo de água, um para proteção e recuperação da Billings, além dos três registrados no Quadro 13:

Quadro 14 - Lista de alguns projetos indicados para recebimento de recursos financeiros do FEHIDRO do ano 2014.

\begin{tabular}{lcc}
\hline \multicolumn{1}{c}{ Projeto } & Tomador & Investimento* \\
\hline $\begin{array}{l}\text { Projeto Rede de Monitoramento Automático da } \\
\text { qualidade das águas superficiais da Sub-Bacia } \\
\text { Juquery-Cantareira: Fase II }\end{array}$ & $\begin{array}{c}\text { Prefeitura Municipal de } \\
\text { Cajamar }\end{array}$ & R\$ 850.553,00 \\
$\begin{array}{l}\text { Desenvolvimento de metodologia e projeto piloto } \\
\text { de revitalização de bacia urbana (Córrego Jaguaré, } \\
\text { município de São Paulo) }\end{array}$ & $\begin{array}{c}\text { Associação Águas Claras do } \\
\text { Rio Pinheiros }\end{array}$ & R\$ 1.667.061,30 \\
$\begin{array}{l}\text { Avaliação da presença de Poluentes Orgânicos } \\
\begin{array}{l}\text { Persistentes (POPs) e Metais Pesados nas aguas, } \\
\text { sedimentos e organismos aquáticos da UGRHI 06 }\end{array}\end{array}$ & CETESB & R $\$ 3.334 .371,00$ \\
\hline
\end{tabular}

Fonte: Deliberação do CBT-AT, nº 4, de 23 de setembro de 2014.

Nota:

* Soma do Valor Financiado e do Valor de Contrapartida. 
Segundo dados do FEHIDRO, sete empreendimentos foram aprovados, sendo três sobre uso racional da água. O Projeto Águas Claras do Rio Pinheiros e a avaliação da CETESB também foram comtemplados (Anexo C, Quadro 17).

Mais uma vez a crise hídrica tomou conta das reuniões do comitê, havendo em quase todas as reuniões o parecer de representantes da SABESP ou CETESB para informar o andamento das ações tomadas.

A Deliberação ${ }^{\circ}$ 9, de 13 de maio, que trata da hierarquização dos empreendimentos a serem indicados para recebimento de recursos do FEHIDRO estabelece que o projeto deve atender ao menos uma das prioridades descritas no Sumário Executivo de 2009, sendo elas:

- Escassez de água;

- Comprometimento dos mananciais de superfície;

- Desorganização da exploração e a ameaça ao manancial subterrâneo;

- Comprometimento da qualidade das águas superficiais;

- Ameaça do lixo; e

- Impermeabilização do solo e ocupação indevida das várzeas.

Outra alteração importante que ocorreu a partir desta deliberação foi a retirada de pontos para empreendimentos cujos tomadores que cancelaram contratos anteriores, havendo em anexo da deliberação lista de tomadores e respectivas porcentagens de cancelamento. Esta iniciativa reduz a incidência de cancelamento de projetos e promove maior comprometimento dos tomadores com relação ao empreendimento que está sendo desenvolvido.

A partir dos critérios estabelecidos pela Deliberação $n^{\circ}$ 9, a Deliberação $n^{\circ} 14$, de 16 de julho, indica 26 empreendimentos, havendo até o momento apenas um projeto em execução solicitado pela FABHAT: "Delimitação de Áreas de Restrição e Controle da Captação e uso das águas subterrâneas da Bacia Hidrográfica do rio Baquirivu-Guaçu e porção sedimentar do entorno leste, município de Guarulhos e Arujá", com valor total de R\$ $1.500 .000,00$.

Este ano mostrou maior variedade em relação a quantidade de temas abordados com relação aos anos 2014 e 2015, onde prevaleceram os tópicos da crise hídrica ocorrida na RMSP. Porém assuntos desconfortantes sobre a legitimidade das ações do comitê foram levantadas, na terceira reunião do $\mathrm{CBH}-\mathrm{AT}$. O coordenador de recursos hídricos, Sr. Rui Brasil solicitou que entrasse na pauta a denúncia ao Ministério Público, ocorrida em março, 
na qual apareciam fatos envolvendo o CBH-AT. Não houve mais informes sobre o ocorrido no restante do ano.

A FABHAT, tomadora de um projeto para contratação do Plano da Bacia, a qual estava em processo de licitação desde 2014, informou ao CBH-AT que o mesmo encontravase em processo judicializado, sendo necessário iniciar a primeira etapa do Plano que não necessita de muitos estudos complementares por não haver conhecimento técnico. Desta forma, foram utilizados dados dos Planos Municipais de Saneamento e Planos de Água e Esgoto da SABESP para cumprir as datas previstas pelo comitê. O "Relatório I - Plano de Bacia Hidrográfica do Alto Tietê - UGRHI 06 - Ano base 2016/2035" foi disponibilizado no site do SigRH em 02 de março de 2017.

$\mathrm{Na}$ reunião do dia 26 de agosto foi apresentado parecer dos coordenadores dos subcomitês sobre o que estava sendo discutido em cada subcomitê. Todos mostraram preocupação com a baixa participação da sociedade civil. Os temas mais abordados em cada subcomitê foram:

- Subcomitê Alto Tietê-Cabeceiras: a Lei Específica do Guaió (Coordenadora do sobcomitê, Sra. Ana Paula);

- Subcomitê Billings-Guarapiranga: PDPA Billings, obras de transferência do sistema Rio Grande para o sistema Alto Tietê (Coordenador do sobcomitê, Sr.Temisotocles Cristofaro);

- Subcomitê Cotia-Guarapiranga: explanou apenas sobre a baixa participação da sociedade civil, não entrando nos assuntos discutidos (Coordenador do sobcomitê, Sr. João Piscarili Ramos);

- Subcomitê Pinheiros-Pirapora: definiram como prioridades (i) recuperação e preservação das áreas de fundo de vale e (ii) educação ambiental para recuperação ou preservação da qualidade das águas.

Na Deliberação $n^{\circ} 25$, de 28 de junho, foram indicados vinte e um empreendimentos ao FEHIDRO, dos quais atualmente seis projetos estão em processo de análise. Entre os projetos indicados e em análise, destaca-se:

Quadro 15 - Lista de alguns projetos indicados para recebimento de recursos financeiros do FEHIDRO do ano 2016, em processo de análise.

\begin{tabular}{lcr}
\hline Projeto & Tomador & Investimento* $^{*}$ \\
\hline \multirow{2}{*}{ Caieiras e suas nascentes } & Prefeitura Municipal de & $\mathrm{R} \$ 1.561 .902,89$ \\
& Caieiras & Continua
\end{tabular}


Quadro 16 - Lista de alguns projetos indicados para recebimento de recursos financeiros do FEHIDRO do ano 2016, em processo de análise.

Continuação

\begin{tabular}{ccc}
\hline Projeto & Tomador & Investimento* \\
\hline $\begin{array}{l}\text { Obra do sistema de esgotamento sanitário no } \\
\text { município de São Paulo - EEE Caiubá, na BH-AT }\end{array}$ & SABESP & R\$2.001.425,12 \\
\hline
\end{tabular}

Fonte: Deliberação do CBT-AT, n 25, de 28 de junho de 2016.

Nota:

* Soma do Valor Financiado e do Valor de Contrapartida. 


\subsection{ALGUMAS INICIATIVAS NA REGIÃO METROPOLITANA DE SÃO PAULO}

Atualmente há diversos termos designados às intervenções de melhorias em ambientes naturais como restauração ecológica, recuperação, renaturalização, revitalização e despoluição. Desta forma, é importante em termos conceituais diferenciá-los para obter melhor entendimento das intervenções discutidas a seguir.

Para o termo restauração ecológica, adota-se a definição: “é uma atividade intencional que inicia ou acelera a recuperação de um ecossistema com respeito à sua saúde, integridade e sustentabilidade", admitindo-se que a degradação foi causada de forma direta ou indireta por ações antrópicas (SER, 2006, p. 1). A restauração ecológica almeja a viabilidade ecológica, objetivando a longo prazo a recriação das comunidades do ecossistema o mais natural possível (ENGEL e PARROTA, 2003). Conforme afirmado por MACEDO et al. (2011, p. 137) pode-se admitir um conceito mais amplo do termo podendo ser incorporado aos projetos dimensões paisagísticas, ecológicas e de qualidade da água. $\mathrm{O}$ autor sugere que a restauração ecológica deva ser acompanhada do sistema de drenagem, as ações de saneamento e relocação da população de áreas irregulares, sendo necessário também a implantação de soluções ecomorfológicas para que "a restauração da integridade ecológica" possa ser alcançada posteriormente.

Já o termo recuperação é definido pelo National Research Council (1992, p. 522) como "um processo concebido para adaptar um recurso natural ou selvagem para servir a um propósito para proveito humano. (...). Frequentemente, é utilizado para se referir a processos que causaram a destruição de ecossistemas nativos, convertendo-os para usos agrícola ou urbano.", sendo um dos termos utilizados mais frequentes. De acordo com ENGEL e PARROTTA (2003), o termo recuperação é adotado no sentido amplo.

BINDER (1998, p. 11) disserta sobre o termo renaturalização apontando que seus objetivos são: "recuperar os rios e córregos de modo a regenerar o mais próximo possível a biota natural, através do manejo regular ou de programas de renaturalização; e preservar as áreas naturais de inundação e impedir (...) usos que inviabilizem tal função", não significando a volta de uma paisagem natural, mas correspondendo ao desenvolvimento sustentável dos rios e da paisagem de acordo com as necessidades da sociedade atual. O autor afirma que apesar das dificuldades enfrentadas nas áreas urbanas devido ao controle de enchentes, é possível aplicar melhorias nesses rios e córregos modificados pelas ações antrópicas como: ampliar o leito do rio, recuperar a continuidade do curso d'água, aplicar técnicas de engenharia ambiental, restabelecer as faixas marginais de proteção e da mata ciliar, reconstituir as estruturas morfológicas do leito e das margens, auxiliar no sucesso da biota e proporcionar elementos de lazer. Estas modificações podem não só melhorar a qualidade dos rios e trazer de volta a fauna, mas propiciar melhorias de saúde mental e física à população.

\footnotetext{
* RECLAMATION - A process designed to adapt a wild or natural resource to serve a utilitarian human purpose. (...). Often used to refer to processes that destroy native ecosystems and convert them to agricultural or urban uses.
} 
GARCIAS e AFONSO (2013) definem revitalização como sendo a preservação, conservação e recuperação ambiental de rios, através de intervenções integradas que proporcionem a melhoria da qualidade da água, das condições ambientais e o uso sustentável dos recursos hídricos.

\subsubsection{PROJETO TIETÊ}

O projeto iniciado em 1992 possui como objetivo principal despoluir a bacia do rio Tietê, diminuindo a poluição causada pelo esgoto gerado na RMSP. O investimento para execução do projeto é proveniente do "Banco Interamericano de Desenvolvimento (BID), da SABESP, da Caixa Econômica Federal e do Banco Nacional de Desenvolvimento Social (BNDES)" (SILVA, 2016, p. 69). A primeira etapa do projeto foi realizada até 1998, focando na “(...) ampliação da infraestrutura de coleta (redes e ligações) e tratamento, com a construção de três novas estações de tratamento de esgoto (Parque Novo Mundo, São Miguel e ABC) e a ampliação de outra, já existente (Barueri)", resultando no aumento da coleta e no tratamento de esgoto: $66 \%$ para $78 \%$ e $24 \%$ para $63 \%$, respectivamente, tendo um investimento de US\$ 1,1 bilhão (BORGES, 2004; SABESP, 2007, p. 25; SILVA, 2016).

Como a primeira etapa focou na construção de estações de tratamento de esgoto, a segunda etapa objetivou a ampliação da rede de coleta na RMSP, passando a coleta de $80 \%$ para $84 \%$ e tratando $70 \%$ do esgoto coletado, com o investimento de US\$ 500 milhões, sendo desenvolvida entre os anos 2000 a 2008 (SABESP, 2007, 2009; SILVA, 2016).

A terceira etapa foi iniciada em 2010 com prazo final para 2016, com o objetivo de aumentar “(...) o índice de coleta de esgoto de $84 \%$ para $87 \%$ e aumentar os níveis de tratamento do esgoto coletado de 68\% para 84\% na RMSP" (SABESP, 2015c, p. 45). Segundo o Relatório de Sustentabilidade de 2015 da empresa, $47 \%$ das obras foram concluídas, $27 \%$ estão em execução e $26 \%$ do projeto definido para esta fase está em processo licitatório. De acordo com SILVA (2016, p. 70), “de um total de US\$ 2 bilhões previstos, já foram investidos R $\$ 1,9$ bilhão nesta fase."

\subsubsection{PROJETO CÓRREGO LIMPO}

Diante da situação dos córregos localizados na capital paulista, o Governo do Estado, por meio da SABESP, juntamente com a Prefeitura de São Paulo, deram início em 2007 ao Programa Córrego Limpo, com o intuito de mudar a situação de degradação dos córregos da capital. O objetivo do programa é melhorar o sistema de esgotamento sanitário, eliminar os lançamentos de esgotos "in natura", limpar as margens e leitos dos corpos hídricos, e promover a reurbanização do entorno ou realocar a população que vive às margens em imóveis irregulares (SABESP, 2007, 2011). 
Em 2009, o programa já havia beneficiado quarenta e dois córregos em sua primeira fase, desenvolvida entre os anos 2007 a 2009, estando vinte e oito deles totalmente despoluídos e quatorze em processo de despoluição, com os principais trechos recuperados, (SABESP, 2009). Já em 2011 a SABESP afirmou que cinquenta e dois córregos a mais haviam sido despoluídos e mais sete estavam sendo trabalhados, totalizando cento e três córregos despoluídos desde 2007.

A terceira fase, ocorrida entre 2011 e 2012 obteve resultados positivos com a despoluição de mais quarenta e três córregos, havendo o investimento de $\mathrm{R}$ \$ 710,3 milhões, dos quais R\$ 109,6 milhões foram da SABESP, até o final da terceira etapa. Entre 2013 e 2014 estava em processo a quarta etapa do projeto que visava despoluir mais 30 córregos, porém houve queda nos resultados, tendo apenas dois córregos com resultados efetivos, totalizando 148 descontaminados até 2015 (SABESP, 2012, 2013a, 2013b, 2014, 2015). O resultado dos anos 2014 e 2015 coincidem com os anos em que ocorreu a crise hídrica na RMSP, podendo haver interferência na efetividade do projeto devido as prioridades de resolução dos problemas de falta de água. Segundo o último Relatório da Administração (SABESP, 2017), o Projeto Córrego Limpo foi paralisado durante a crise hídrica dos anos 2013a, 2014 e 2015. Em 2015 houve investimento de R \$ 3,8 milhões e em 2016 de R \$ 4,8 milhões para “zeladoria e monitoramento de córregos” (SABESP, 2015, 2017, p. F33).

Apesar de ser um projeto efetuado apenas no município de São Paulo, seus resultados positivos também auxiliam nos resultados do Projeto Tietê (SABESP, 2012, 2013a).

Em pesquisa realizada por TZORTZIS e KNIESS (2016) sobre a despoluição do córrego Mandaqui, contemplado no Programa, constatou-se a melhoria na qualidade de vida da população do entorno e o interesse da comunidade do bairro Mandaqui sobre as questões ambientais e sua disposição em promover iniciativas em prol da diminuição da poluição difusa às margens do córrego.

SILVA (2014) em pesquisa sobre a eficácia da despoluição através das cargas pontuais e difusas dos córregos Ibiraporã e Sapé, concluiu que a gestão participativa foi de extrema importância, destacando-se o envolvimento da população do entorno. No entanto foram apresentados problemas quando não havia a colaboração dos habitantes e as questões relacionadas ao remanejamento da população local. A poluição difusa foi tópico citado por ANELLI (2015) como um dos fatores que tornam a avaliação de eficácia do programa difícil de ser definida, devido à constatação feita por pesquisadores, identificando as dificuldades de manutenção da limpeza dos corpos hídricos. SILVA (2014) ainda aborda que do ponto de vista ambiental, constatou-se a falta de abrigos para organismos aquáticos, quando aplicada as técnicas de canalização, limitando a formação de comunidades complexas, devido à inserção de lajes de concreto.

Em estudo realizado por RAMIRES JR. et al. (2015, p. 129), conclui-se que os principais conflitos encontrados na manutenção dos córregos contemplados pelo programa são: 
i) reocupação irregular às margens dos córregos, ii) reincidência da poluição (descarte inadequado de lixo e entulho, lançamento irregular de esgoto in natura) em virtude da baixa percepção dos resultados positivos quanto à manutenção da qualidade ambiental dos cursos d'águas urbanos e iii) não engajamento da população em torno da questão.

RAMIRES JR. et al. (2015) ainda afirmam que apenas 53\% dos córregos mantiveram a situação de despoluídos, associando a necessidade de intervir não apenas com medidas estruturais e não estruturais de engenharia, mas também inserir a comunidade de forma efetiva no processo.

As ligações clandestinas de esgoto e as ligações cruzadas são outros fatores que prejudicam a integridade dos rios e córregos e interverem nos bons resultados de despoluição. Segundo MORETTI (2005) ocorrem não só ligações clandestinas na rede de esgoto, mas também ocorre ligação cruzada entre rede pluvial e de esgoto, o que nem sempre acontece de forma irregular, sendo feita muitas vezes, pelo Poder Público.

\subsubsection{PARQUES LINEARES}

Uma alternativa encontrada para minimização dos impactos nos corpos d'água e sua despoluição é a implantação de parques lineares. A partir dos anos 1980 e 1990 os parques lineares voltaram a ter destaque, como havia sido sugerido por Saturnino de Brito, adotandoos como "uma estratégia ambiental e paisagística de forte apelo visual e funcional para a população", atuando de forma positiva para dar aos corpos hídricos visibilidade na cidade (ANELLI, 2015, p. 75). JACOBI et al., (2015a) dissertam que os parques lineares são utilizados como ferramentas por políticas públicas de saneamento e habitação para melhoria local, mudando a paisagem urbana e restaurando os espaços públicos. Estas transformações auxiliam na mudança de pensamento e comportamento que os habitantes locais possuem em relação aos rios e córregos, como afirmam os autores. DICTORO e HANAI $(2016,117)$ também recomendam a elaboração e realização de "programas e ações de sensibilização para conservação da água e para a valorização dos rios” que subsidiem atuações de educação ambiental, reforçando junto à população suas relações com o meio ambiente.

SILVA-SÁNCHEZ e JACOBI (2016) dissertam que os parques lineares podem desempenhar papel importante auxiliando a manutenção da qualidade ambiental dos espaços urbanos, aumentando as áreas permeáveis com cobertura vegetal, evitando inundações, ajudam a conservar a qualidade das águas superficiais e subterrâneas, além de regular o microclima, proporcionando um ambiente de bem-estar físico e social e de educação ambiental. 
Segundo a Lei $\mathrm{n}^{\circ}$ 16.050, de 31 de julho de 2014, o Plano Diretor Estratégico do Município de São Paulo, os parques urbanos, lineares e naturais fazem parte da rede hídrica ambiental, admitindo sua importância na manutenção e preservação da qualidade dos corpos hídricos e em sua funcionalidade como áreas de lazer e recreação para a população. O Plano propôs a consolidação de 167 parques distribuídos entre linear, urbano e natural, totalizando 107 parques lineares na lista entre "existente" e "em implantação". De acordo com SILVASÁNCHEZ e JACOBI (2016), a maior diferença entre parques lineares e parques urbanos está em sua ligação com a recuperação dos recursos hídricos.

Verifica-se que mesmo com a implantação de parques lineares, é frequente detectar a falta de saneamento em toda extensão dos corpos hídricos, o mau cheiro das águas, a presença de resíduos sólidos às margens e no leito dos rios e falta de segurança tornando o ambiente propício a roubos, prostituição e tráfico e uso de drogas (SILVA-SÁNCHEZ e JACOBI, 2016). Estas constatações indicam a necessidade de trabalhar com políticas públicas integradas que permitam a realização não só do saneamento ou da implantação de parques lineares, mas que envolvam o gerenciamento dos resíduos sólidos, os trabalhos de conscientização e envolvimento da população, segurança pública, além de trabalhos contínuos de saneamento, urbanização e manutenção dos parques.

SILVA (2014) destaca a complexidade de implantar um parque linear quando há a necessidade de realocar a população do entorno, sendo a alternativa mais viável a construção de conjuntos habitacionais próximos aos corpos hídricos. Esta opção proporciona maior segurança e menor vulnerabilidade aos habitantes, sem retirar a população de seu local.

\subsection{O COMITÊ DA BACIA HIDROGRÁFICA DO ALTO TIETÊ, O FEHIDRO E A PARTICIPAÇÃO SOCIAL}

A evolução da maturidade do Comitê é observada ao longo dos anos, podendo ser definidas etapas distintas e características em cada uma delas, o que altera o formato e a exposição dos temas discutidos, avaliados e deliberados dentro do Comitê. A transparência na disponibilidade dos dados da gestão dos recursos hídricos permitiram que fossem adquiridas todas as Atas e Deliberações através do site do Sistema Integrado de Gerenciamento de Recursos Hídricos do Estado de São Paulo e do site do CBH-AT, com exceção dos anos 2009 e 2012, que foram solicitados diretamente ao CBH-AT. Não foram obtidas todas as atas do ano 2012, prejudicando a análise deste ano, que coincidiu com as vésperas da crise hídrica.

Inicialmente observa-se um colegiado que buscava trazer informações dispersas com o intuito de igualar o conhecimento entre os membros, porém ainda não haviam sido criados parâmetros de prioridades e nem conhecimento básico sobre a própria bacia, de forma que as reuniões não eram muito objetivas. A forma com que se apresentavam determinados temas mostra que alguns membros possuíam a visão do Comitê como um local para resolução de 
problemas pontuais, provavelmente pela falta de diretrizes prioritárias, característico de um sistema novo em formação de sua base identitária.

Desta forma, iniciou-se a criação de Câmaras Técnicas com o intuito de fragmentar os temas abordados nas reuniões gerais e aprofundar os tópicos direcionados para as mesmas. Os critérios de seleção de projetos a serem indicados para o recebimento de recursos do FEHIDRO foram definidos dois anos após a criação do Comitê. Estes critérios e os empreendimentos indicados podem apontar para as ações de maior visibilidade e necessidade definidas pelos membros do Comitê. A criação dos subcomitês, que iniciou sua formação quatro anos após a fundação do CBH-AT, apesar de ser solicitado em reuniões desde o primeiro ano, seguiu a linha de objetividade das Câmaras Técnicas, permitindo que os assuntos pertinentes a cada sub-bacia pudessem ser discutidos de forma mais ampla e levados para o colegiado com diretrizes definidas.

Porém, ao longo dos anos ocorreram limitações de dados após a criação dos subcomitês, sendo os temas direcionados para cada grupo, sem que houvesse posteriormente um parecer a respeito do assunto, assim como ocorreu com as Câmaras Técnicas. Contudo, com a evolução das diretrizes e organização do CBH-AT, passaram a ser apresentados tópicos relevantes que estavam sendo discutidos no âmbito regional ou técnico e mais recentemente começaram a ser apresentados nos informes o parecer dos subcomitês, ampliando a visibilidade dos problemas e ações tomadas na bacia como um todo.

A formação de Câmaras Técnicas e Grupo Técnicos também passaram por fases de amadurecimento, havendo a redução do números de Câmaras Técnicas após a reformulação do estatuto do CBH-AT, objetivando manter apenas as estritamente necessárias que se mantem em todos os períodos, como ocorre com a Câmara Técnica de Investimentos (que trata sobre a hierarquização, prioridades e divisão dos recursos destinados à Bacia do Alto Tietê) e a Câmara Técnica de Planejamento e Articulação (que tem como prioridade os estudos relativos a política de recursos hídricos, os mananciais, licenciamentos, impactos de empreendimentos, entre outros temas), sendo dividida em cinco Grupos Técnicos: Consultas Ambientais, Gestão de Demanda, Leis de Mananciais, Outorga do Cantareira e Planejamento. Atualmente também há a Câmara Técnica de Monitoramento Hidrológico criada em 2015, em decorrência da crise hídrica sofrida pela RMSP.

A equação de seleção de empreendimentos a serem indicados para receber recursos financeiros do FEHIDRO sempre ocorreu de forma dinâmica, passando todos os anos por deliberação e atualizando de acordo com as necessidades emergenciais de cada período. Atualmente observa-se uma hierarquização muito mais madura com a qual é possível selecionar não apenas os projetos de maior interesse, mas também pontuar os tomadores de cada empreendimento de acordo com seu histórico de parecer e entrega dos projetos finalizados, diminuindo a ocorrência de transtornos com atrasos e displicência em relação aos trâmites burocráticos exigidos pelo FEHIDRO.

Destacam-se entre os anos 2008 a 2010 a permanência de projetos de despoluição e enquadramento dos corpos hídricos como sendo prioritários para alguns subcomitês. O 
enquadramento dos corpos hídricos é um assunto ainda polêmico, necessitando de maiores iniciativas para reenquadrar os corpos hídricos da RMSP e unir a isto metas de melhorias com descarte de efluentes cada vez mais próximos as condições boas de qualidade da água.

Apesar da diversidade de temas abordados e das fases do Comitê encontradas, prevaleceram entre todos os anos determinados temas recorrentes que se mostraram como sendo de maior preocupação para o colegiado como os mananciais, o Projeto Tietê, a questão do abastecimento e os incidentes com inundações.

A preocupação com os mananciais esteve presente principalmente devido à criação de Leis Específicas para cada manancial. Ocorreram em alguns momentos discussões sobre uso e ocupação do solo nas Áreas de Preservação de Mananciais decorrentes de problemas ocorridos, porém o foco estava voltado mais para a legislação do que para as soluções dos problemas advindos pontualmente.

As questões da falta de água para abastecimento e das inundações foram apresentadas em todos os períodos do Comitê, tendo maior evidência em épocas em que ocorriam os incidentes, principalmente a escassez ocorrida entre os anos 2001-2004 e a crise hídrica dos anos 2014-2015, concentrando a maior parte das preocupações do Comitê.

Os resíduos sólidos tomaram maior visibilidade, principalmente a partir dos anos 2003, buscando aumentar a rede de coleta de resíduos sólidos, criar centros de triagem de materiais reciclados e eliminar locais de descarte inadequados na RMSP. Observa-se que a maioria dos projetos estavam alocados em cidades periféricas agrupadas nos indicadores menos favorecidos do Índice Paulista de Responsabilidade Social.

A crise hídrica severa ocorrida na RMSP custou a paralização ou desaceleração de projetos de despoluição, como o Projeto Tietê e o Programa Córrego Limpo, ambos geridos pela SABESP com o intuito de aumentar a rede de esgotamento sanitário, remover fontes clandestinas de descarte de esgoto, aumentar o nível de tratamento de esgoto coletado e como consequência melhorar a qualidade das águas de rios e córregos. Aliado a estas ações, estão a reurbanização do entorno dos corpos hídricos e a realocação da população.

Porém, existem outras atividades a serem desenvolvidas juntamente com as ações de saneamento, canalização e urbanização, necessitando conscientizar a população local, torná-la parte do processo para que se obtenha resultados positivos a longo prazo e não apenas a curto e médio prazo, invalidando as ações tomadas anteriormente.

Como visto ao longo do trabalho, devido a fatores culturais e sociais a maioria dos habitantes não constroem vínculos com a cidade de forma que se tenha a sensação de pertencimento do local, havendo deste modo, descaso com relação ao ambiente. Esta falta de identidade e apego à cidade conduz à falta de cuidados, que favorecem a poluição principalmente por cargas difusas. 
Por isso a inclusão de projetos de educação ambiental, o acompanhamento da população, o envolvimento de líderes locais nos projetos são de extrema importância para que o entorno se torne um ambiente de lazer e cuidado para os habitantes, não apenas prevenindo a proliferação de doenças de veiculação hídrica, mas também tornando a cidade mais sustentável e saudável para seus habitantes, como citado pelos autores ZANETI e SÁ (2002), PINTO, AMARAL e HONÓRIO (2006), SILVA (2014) e ANELLI (2015).

A adequação do entorno com parques lineares é uma alternativa que deve ser mais utilizada, pois eles proporcionam ambientes de lazer para a população e permitem maior contato com o ambiente natural. Porém os projetos de implantação dos parques lineares devem ser acompanhados de sustentação do setor de segurança pública, havendo iluminação e formas de prevenir a utilização inadequada do local, proporcionando maior segurança e aceitabilidade por parte da comunidade local (SILVA, 2014; ANELLI, 2015; SILVASÁNCHEZ e JACOBI, 2016).

Outra observação necessária é em relação aos recursos financeiros alocados para projetos. Em 2016 foram alocados por volta de 19,2 milhões do FEHIDRO para os projetos na BH-AT. Já a SABESP, que obteve uma receita líquida de 14,1 bilhões e um lucro de 2,9 bilhões, alocou os seguintes recursos:

Quadro 16 - Investimentos da SABESP em 2016.

\begin{tabular}{cc}
\hline Setor ou projeto & Valor \\
\hline Expansão da infraestrutura de coleta e tratamento de esgoto & $\mathrm{R} \$ 1,2$ bilhão \\
Projeto Tietê & $\mathrm{R} \$ 342$ milhões \\
Projeto Córrego Limpo & $\mathrm{R} \$ 4,8$ milhões \\
Pesquisa e inovação em água e esgoto & $\mathrm{R} \$ 11,9$ milhões \\
\hline
\end{tabular}

Fonte: SABESP, 2017.

Os investimentos em 2016 do Projeto Tietê chegaram a R \$ 2 bilhões, sendo este valor proveniente dos recursos da SABESP, como citado no Quadro 17, e de investimentos do BID e BNDES. O Projeto Córrego Limpo não obteve continuidade na despoluição de rios e córregos, sendo este valor investido em 2016 para zeladoria e monitoramento (SABESP, 2017).

Sobre os projetos indicados pelo Comitê e os empreendimentos aprovados pelo FEHIDRO, observa-se que a maior parte é composta por projetos de educação ambiental em todos os âmbitos, percorrendo temas de preservação de mananciais, bacias, rios e vegetação, assim como difusão do conhecimento sobre descarte de resíduos sólidos.

Os investimentos na despoluição de rios e córregos devem ser mais prioritários e devem ser dispostos de forma organizada e unida não só com a canalização e reurbanização 
ou realocação da população do entorno, mas também com projetos de educação ambiental, resíduos sólidos, serviços de coleta e tratamento de esgoto e demais problemáticas que fazem parte desde tema complexo, assim como o incentivo à participação social em todas as fazes dos projetos, obtendo resultados mais satisfatórios e que permitem avanços não só de melhores condições de saúde à população local, mas que permite a introdução de paradigmas que permeiam o âmbito das cidades saudáveis e sustentáveis.

Os resíduos sólidos são um dos maiores causadores de poluição difusa dos córregos e rios, sendo estes trabalhos de melhoria em sua gestão extremamente importantes. Porém há ainda muito o que se fazer nesse quesito, como divulgação da forma correta de descarte de materiais recicláveis e a ampliação do serviço de coleta e destinação destes materiais, sendo encontrado o serviço apenas em algumas localidades da capital paulista.

Como já citado anteriormente, a educação ambiental, vinculada aos projetos de despoluição contribui para a maior efetividade dos resultados a longo prazo. Recomenda-se que estas iniciativas sejam desenvolvidas antes da etapa de implementação, havendo reuniões de caráter informativo, divulgação dos objetivos do projeto, mecanismos de troca de ideias para que a população possa tirar suas dúvidas e informar quais são suas prioridades, havendo o respeito com a opinião daqueles que habitam o ambiente e trazendo-os para auxiliar no sucesso do projeto.

Apesar de a problemática do uso e ocupação do solo não ser muito discutida no Comitê, é necessário levantar a questão, pois de acordo com a legislação as áreas irregulares não podem receber a infraestrutura de urbanização como saneamento ambiental, luz elétrica e obras de melhorias estruturais. Como consequência tem-se uma população que consta fora dos índices de saneamento, deflagradas com a diminuição e a fragilidade social estando mais propensa a ser atingida por desastres naturais como enchentes e deslizamento de terra e tendo maior probabilidade de ser afetada por doenças de veiculação hídrica. Por outro lado, localidades com moradias irregulares que não são classificadas como de baixa renda e/ou comunidades, conseguem ter a infraestrutura urbana facilmente, havendo discrepância na efetivação das leis quando se trata de classes sociais.

Vê-se que a iniciativa de realocar a população ou inserir a urbanização adequada nas localidades dos córregos privilegiados pelo Programa Córrego Limpo é uma tentativa de minimizar estes impactos e proporcionar mais dignidade àquela população, porém esta iniciativa ainda é pouco diante da proporção e da dinâmica sempre ativa da cidade, necessitando não só de políticas públicas de uso e ocupação do solo e moradias populares, mas também de interferências ativas que sejam flexíveis a cada caso propiciando soluções alternativas que integrem o meio ambiente com o social, admitindo o social como parte da estrutura que proporciona condições dignas para a população, assim como acesso a saúde e educação.

A partir das constatações apresentadas, admite-se a necessidade de trabalhar dentro do ambiente urbano com diversas esferas que fazem parte da gestão e das melhorias públicas aplicadas nas cidades, fazendo-se presente a composição de diversos atores compilando para 
um fim positivo de forma conjunta, considerando todas as variáveis exigidas pela boa composição e o sucesso de programas de despoluição ou recuperação de rios e córregos urbanos. TRAVASSOS e SCHULT (2013, p. 302-304) em análise sobre planos e programas para recuperação socioambiental dos fundos de vale, afirmaram:

(...) a metodologia de escolha do Plano Municipal de Habitação prioriza as ocupações mais precárias e, portanto, mais vulneráveis, o Programa Córrego Limpo possui como premissa a conclusão das intervenções em curto prazo de tempo, dois anos. Por outro Lado, o Programa 100 Parques, da SVMA*, embora tenha atendido a algumas subprefeituras em sua demanda por parques lineares, tem como política enfatizar a implantação de parques em áreas livres de ocupação, (...), principalmente na Área de Proteção aos Mananciais e na Zona de Amortecimento da Cantareira.

Assim, é possível dizer que, enquanto os programas da Sehab** começam pelas áreas de maior conflito, o Programa 100 Parques (com exceções) e o Programa Córrego Limpo optam por áreas onde os conflitos são menores, no intuito de realizar mais ações em um espaço de tempo mais curto e aproveitar as oportunidades. Esse desencontro faz com que as intervenções em áreas de habitação precária nos fundos de vale, especialmente no que concerne ao saneamento, à drenagem e à criação de espaços públicos, sejam restritas.

As autoras apontam como consequência inadequações em todos os programas.

Outro ponto que diverge entre diversos autores é a canalização dos cursos d'água, pois é comprovado que as canalizações não preveem espaço para a recuperação da vegetação, não permitem que os rios e córregos mantenham seus meandros (BROCANELI e STUERME, 2008) e não permitem que a biota se desenvolva com plenitude, como já citado anteriormente.

Sendo a participação social um aspecto chave para a composição de cidades saudáveis e sustentáveis e como um sistema tripartite e descentralizado, o CBH-AT deve alocar componentes das três esferas do poder e membros da sociedade civil, desde que o mesmo seja de um grupo de empresa que utiliza os recursos hídricos, instituição de ensino ou de uma organização não-governamental. Nas atas das reuniões constam relatos dos membros do comitê, não sendo possível identificar a participação social do comitê com a sociedade civil. Apesar de todas as informações constarem no site e de ter fácil acesso via telefone, não foram encontrados indícios de chamadas para a participação da população geral.

\footnotetext{
* SVMA - Secretaria do Verde e do Meio Ambiente

**: Sehab-Secretaria Municipal de Habitação
} 
Através dos levantamento e análises realizados, admite-se que apesar da despoluição ser tópico importante, a visão do Comitê ainda limita-se ao entendimento físico e não social dos benefícios alcançados com a melhoria da qualidade das águas. Esta visão acaba prejudicando a despoluição quando se trata de classificação de prioridades, sendo um problema jogado para decisões a frente.

A interação entre os diversos setores da gestão pública permite maior compreensão das necessidades das cidades e de seus habitantes e com isso possibilita a adoção de medidas mais completas, que permeiam diversos setores e possibilitam melhorias a médio e longo prazo. Por isso, é de extrema importância a interação entre especialistas das mais diversas áreas, propondo a manifestação de alternativas e visões diferentes sobre um mesmo tópico, de forma que sejam alcançadas respostas que permeiam todos os setores necessários para o melhor desenvolvimento dos projetos. 


\section{REFERENNCIAS}

ADRIANO, J. R.; WERNECK, G. A. F.; SANTOS, M. A. D.; SOUZA, R. D. C. A construção de cidades saudáveis: uma estratégia viável para a melhoria da qualidade de vida? Revista Ciência e Saúde Coletiva, Rio de Janeiro, v. 5, n. 1, p. 53-62, 2000.

ALMEIDA, E. S. Cidade/município saudável - a questão estratégica: o compromisso político. Revista Saúde e Sociedade, São Paulo, v. 6, n. 2, p. 71-81, 1997.

ALVIM, A. T. B. A contribuição do Comitê do Alto Tietê à gestão da bacia metropolitana, 1994 - 2001. 2003. Tese (Doutorado em Estruturas Ambientais e Urbanas) Faculdade de Arquitetura e Urbanismo, Universidade de São Paulo, São Paulo, 2003.

ANA - Agência Nacional de Águas. Atlas Brasil. Abastecimento Urbano de Água: Região Metropolitana de São Paulo. 2010. Disponível em: < http://atlas.ana.gov.br>. Acesso em: 26/01/2016.

ANA - Agência Nacional de Águas. Programa Despoluição de Bacias Hidrográficas PRODES. 2015. Disponível em: <http://www.ana.gov.br/prodes/prodes.asp>. Acesso em: $17 / 02 / 2017$.

ANELLI, R. L. S. Uma nova cidade para as águas urbanas. Estudos Avançados, v. 29, n. 84, p. 69-84, 2015.

ARAUJO, E. C.; RIBEIRO, N. F. Cidades verdes: contribuições para o debate sobre rios urbanos e corredores verdes. Periódico Técnico e Científico Cidades Verdes, v. 3, n. 5, p. 117-132, 2015.

ASSUNÇÃO, P. As condições urbanas da cidade de São Paulo no século XIX. 2009. Disponível em: http://www.historica.arquivoestado.sp.gov.br. Acesso em: 29/09/2016.

AZEVEDO, A. (Coord.) A cidade de São Paulo: estudos de geografia urbana. São Paulo: Companhia Editora Nacional, 1958. 40 p.

BAENINGER, R. São Paulo e suas migrações no final do século 20. São Paulo em Perspectiva, v. 19, n. 9, p. 84-96, 2005.

BARTALINI, V. A trama capilar das águas na visão cotidiana da paisagem. Revista USP, São Paulo, n. 70, p. 88-97, 2006.

BASSO, L. A.; RIGHI, E. Casos de hepatite e a leptospirose no município de Porto Alegre RS entre os anos de 2007 a 2011. Hygeia: Revista Brasileira de Geografia Médica e da Saúde, v. 11, n. 20, p. 66-84, 2015. 
BENICIO, M. H. D’A; MONTEIRO, C. A. Tendência secular da doença diarreica na infância na cidade de São Paulo (1984-1996). Revista de Saúde Pública, São Paulo, v. 34 (6 Supl), p. 83-90, 2000.

BINDER, W. Rios e córregos, preservar - conservar - renaturalizar. A recuperação de rios, possibilidades e limites da engenharia ambiental. Orientação técnica Projeto PLANÁGUA SEMADS/GTZ. Rio de Janeiro: SEMADS, 1998.

BONDUKI, N. O modelo de desenvolvimento urbano de São Paulo precisa ser revertido. Estudos Avançados, v. 25, n. 71, p. 26-36, 2011.

BORELLI, E. Mananciais urbanos e sustentabilidade na grande São Paulo. Anais: Encontros Nacionais da ANPUR, v. 14, 2011.

BORGES, M. L. Observando o Tietê. São Paulo: Fundação SOS, 2004.

BRANDÃO, I. R. Na trilha do município saudável. In: Organização Pan-Americana de Saúde (OPAS). Políticas integradas em rede e a construção de espaços saudáveis: boas práticas para a iniciativa do Rostos, Vozes e Lugares. Brasília, OPAS, 2010, p. 31-60.

BRASIL. Decreto ${ }^{\circ}$ 24.643, de 10 de julho de 1934. Decreta o Código das águas. Diário Oficial da União, Rio de Janeiro, RJ, 20 jul. 1934. Seção 1, p. 14.738.

Lei Complementar $\mathrm{n}^{\circ} 14$, de 8 de junho de 1973. Estabelece as regiões metropolitanas de São Paulo, Belo Horizonte, Porto Alegre, Recife, Salvador, Curitiba, Belém e Fortaleza. Diário Oficial da União, Brasília, DF, 11 jun. 1973. Seção 1, p. 5.585.

Conselho Nacional de Meio Ambiente - CONAMA. Resolução n 001, de 23 de janeiro de 1986. Diário Oficial da União, Brasília, DF, 17 fev. 1986.

Constituição (1988). Constituição da República Federativa do Brasil. Brasília, DF: Senado Federal, 1988.

Lei $\mathrm{n}^{\circ}$ 9.433, de 8 de janeiro de 1997. Política Nacional de Recursos Hídricos. Institui a Política Nacional de Recursos Hídricos, cria o Sistema Nacional de Gerenciamento de Recursos Hídricos, regulamenta o inciso XIX do art. 21 da Constituição Federal, e altera o art. $1^{\circ}$ da Lei $n^{\circ} 8.001$, de 13 de março de 1990, que modificou a Lei $n^{\circ} 7.990$, de 28 de dezembro de 1989. Diário Oficial da União, Brasília, DF, 09 jan. 1997. Seção 1, p. 470.

Lei $\mathrm{n}^{\circ} 10.257$, de 10 de julho de 2001. Estatuto da Cidade. Regulamenta os artigos 182 e 183 da Constituição Federal, estabelece diretrizes gerais da política urbana e dá outras providências. Diário Oficial da União, Brasília, DF, 11 jul. 2001. Seção 1, p. 01.

Lei $\mathrm{n}^{\circ} 11.445$, de 5 de janeiro de 2007. Lei de Saneamento Básico. Estabelece diretrizes nacionais para o saneamento básico; altera as Leis n ${ }^{\circ} \mathrm{s} 6.766$, de 19 de dezembro de 1979, 8.036, de 11 de maio de 1990, 8.666, de 21 de junho de 1993, 8.987, de 13 de fevereiro 
de 1995; revoga a Lei $\mathrm{n}^{\circ}$ 6.528, de 11 de maio de 1978; e dá outras providências. Diário Oficial da União, Brasília, DF, 9 de jan. 2007. Seção 1, p. 3.

Lei $\mathrm{n}^{\circ}$ 12.305, de 2 de agosto de 2010. Lei de Resíduos Sólidos. Institui a Política Nacional de Resíduos Sólidos; altera a Lei no 9.605, de 12 de fevereiro de 1998; e dá outras providências. Diário Oficial da União, Brasília, DF, 3 de ago. 2010. Seção 1, p. 3.

Portaria $\mathrm{n}^{\circ}$ 2.446, de 11 de novembro de 2014. Redefine a Política Nacional de Promoção da Saúde (PNPS). Diário Oficial da União, Brasília, DF, 13 de nov. 2014. Seção 1, p. 68.

BROCANELI, P. F. O ressurgimento das águas na paisagem paulistana: fator fundamental para a cidade sustentável. 2007. $323 \mathrm{f}$. Tese (Doutorado) - Faculdade de Arquitetura e Urbanismo, Universidade de São Paulo, São Paulo, 1995.

BROCANELI, P. F.; STUARME, M. M. Renaturalização de rios e córregos no município de São Paulo. Exacta, São Paulo, v. 6, n. 1, p. 147-156, 2008.

BUCHALLA, C. M.; WALDMAN, E. A.; LAURENTI, R. A mortalidade por doenças infecciosas no início e no final do século XX no Município de São Paulo. Revista Brasileira de Epidemiologia, v. 6, n. 4, p. 335-344, 2003.

CANOLLY, J. F. Rio Anacostia: Washington, DC, Estados Unidos. In: MACHADO, A. T. G. M.; LISBOA, A. H.; ALVES, C. B. M.; LOPES, D. A.; GOULART, E. M. A.; LEITE, F. A.; POLIGNANO, M. V. (Org.). Revitalização de rios no mundo: América, Europa e Ásia. Belo Horizonte: Instituto Guaicuy, 2010, p. 97-118.

CARLOS, A. F. A. São Paulo: dinâmica urbana e metropolização. Revista Território, Rio de Janeiro, ano VII, n. 11, 12 e 13, p. 77-89, 2003.

CARTA, DE OTTAWA. Primeira conferência internacional sobre promoção da saúde. Ottawa, novembro de, $1986 . \quad$ Disponível em: http://bvsms.saude.gov.br/bvs/publicacoes/carta_ottawa.pdf. Acesso em 12/09/2016.

CASTEROT, B. Rio Sena: Paris, França. In: MACHADO, A. T. G. M.; LISBOA, A. H.; ALVES, C. B. M.; LOPES, D. A.; GOULART, E. M. A.; LEITE, F. A.; POLIGNANO, M. V. (Org.). Revitalização de rios no mundo: América, Europa e Ásia. Belo Horizonte: Instituto Guaicuy, 2010, p. 119-130.

CLEMENTINO, M. L. M.; ALMEIDA, L. S. B. Construção técnico-política de governança metropolitana. Cadernos Metrópole, São Paulo, v. 17, n. 33, p. 201-224, 2015.

CBH-AT - Comitê da Bacia Hidrográfica do Alto Tietê. Plano da Bacia Hidrográfica do Alto Tietê: sumário executivo. São Paulo: Fundação de apoio à Universidade de São Paulo (FUSP), 2002. 
Plano da Bacia Hidrográfica do Alto Tietê - Relatório final. São Paulo: Fundação de apoio à Universidade de São Paulo (FUSP), v. 1, 2009a.

. Plano da Bacia Hidrográfica do Alto Tietê - Relatório final. São Paulo: Fundação de apoio à Universidade de São Paulo (FUSP), v. 2, 2009b.

. Conheça a Bacia do Alto Tietê: caracterização geral. São Paulo, 2014a.

$2014 b$.

Conheça a Bacia do Alto Tietê: sistemas de esgotamento sanitário. São Paulo,

Conheça a Bacia do Alto Tietê: drenagem urbana. São Paulo, 2014c.

Estatuto do Comitê da Bacia Hidrográfica do Alto Tietê. Aprovado pela Deliberação CBH-AT n 02 de 04/06/013 e alterado pela Deliberação CBH-AT n ${ }^{\circ} 04$ de 31/03/2015. São Paulo, 2015a.

. Relatório de situação dos recursos hídricos - Bacia Hidrigráfica do Alto Tietê - Ano base 2014. São Paulo, 2015b.

Relatório I - Plano de Bacia Hidrográfica do Alto Tietê - UGRHI 06 - Ano base 2016/2035. São Paulo, 2016.

CETESB - Companhia Ambiental do Estado de São Paulo. Qualidade das águas superficiais do estado de São Paulo - Parte 1 - Águas Doces - 2015. São Paulo: CETESB, $2016 \mathrm{a}$.

Qualidade das águas subterrâneas do estado de São Paulo - 2013-2015. São Paulo: CETESB, 2016b.

$2016 c$.

Inventário estadual de resíduos sólidos urbanos 2015. São Paulo: CETESB,

Qualidade das águas superficiais do estado de São Paulo - Parte 1 - Águas Doces - 2015. Apêndice C: Índices de Qualidade das Águas. São Paulo: CETESB, 2016d.

Qualidade das águas superficiais do estado de São Paulo - Parte 1 - Águas Doces - 2015. Apêndice F: Mapas UGHRI 01 - 22. São Paulo: CETESB, 2016e.

CONICELLI, B. P. Gestão das águas subterrâneas na Bacia Hidrográfica do Alto Tietê (SP). 2014. Tese (Doutorado em Hidrogeologia e Meio Ambiente) - Instituto de Geociências, Universidade de São Paulo, 2014.

CUNHA, S. B. da. Canais fluviais e a questão ambiental. In: CUNHA, S. B. da; GUERRA, A. J. T. A questão ambiental: diferentes abordagens. 3. ed. Rio de Janeiro: Bertrand Brasil, 2003. Cap. 7. p. 219-238. 
CUSTÓDIO, V. Dos surtos urbanísticos do final do século XIX ao uso das várzeas pelo Plano de Avenidas. Geosul, Florianópolis, v. 19, n. 38, p. 77-98, 2004.

DALFOVO, M. S. et al. Métodos quantitativos e qualitativos: um resgate teórico. Revista Interdisciplinar Científica Aplicada, Blumenau, v. 2, n. 4, p. 01-13, Sem. II. 2008.

DICTORO, V. P.; HANAI, F. Y. Análise da relação homem-água: a percepção ambiental dos moradores locais de Cachoeira de Emas - SP, Bacia Hidrográfica do rio Mogi-Guaçu. Ra'e Ga - O Espaço Geográfico em Análise, Curitiba, v. 36, p. 92-120, 2016.

DINIZ, C. C.; CAMPOLINA, B. A região metropolitana de São Paulo: reestruturação, reespacialização e novas funções. Revista EURE, Santiago do Chile, v. 33, n. 98, p. 27-43, 2007.

ENGEL, V. L.; PARROTTA, J. A. Definindo a restauração ecológica: tendências e perspectivas mundiais. In: KAGEYAMA, P. Y.; OLIVEIRA, R. E.; MORAES, L. F. D.; ENGEL, V. L.; GANDARA, F. B. Restauração ecológica de ecossistemas naturais. Botucatu: FEPAF, 2003. p. 3-26.

FARIA, A. A. C. Abastecimento de água na cidade de São Paulo (1554-1960). Revista do Arquivo Municipal, São Paulo: Departamento do Patrimônio Histórico, v. 203, p. 37-56, 2004.

FELICIO, B. C.; SILVA, R. S. Ações antrópicas nas áreas lindeiras a corpos d'água urbanos. In: XIII Encontro da Associação Nacional de Pós-Graduação e Pesquisa em Planejamento Urbano e Regional, Florianópolis, 2009.

FERRAZ, S. T. Promoção da saúde: viagem entre dois paradigmas. Revista de Administração Pública, Rio de Janeiro, v. 32, n. 2, p. 49-60, 1998.

FERREIRA, M. U.; FERREIRA, C. S.; MONTEIRO, C. A. Tendência secular das parasitoses intestinais na infância na cidade de São Paulo (1984-1996). Revista de Saúde Pública, São Paulo, v. 34 (6 Supl), p. 76-82, 2000.

FERREIRA, H. S.; ASSUNÇÃO, M. L.; VASCONCELOS, V. S.; MELO, F. P.; OLIVEIRA, C. G.; SANTOS, T. O. Saúde de populações marginalizadas: desnutrição, anemia e enteroparasitoses em crianças de uma favela do "Movimento dos Sem Teto", Maceió, Alagoas. Revista Brasileira de Saúde Materno Infantil, Recife, v. 2, n. 2, p. 177-185, 2002.

FIORAVANTI, C. Entre Paredes de Concreto. Pesquisa Fapesp, São Paulo, v. 214, p. 16-25, 2013.

FOSTER, S.; HIRATA, R.; GOMES, D.; D’ELIA, M.; PARIS, M. Proteção da qualidade da água subterrânea: um guia para empresas de abastecimento de água, órgãos municipais e agências ambientais. Banco Mundial, 2006. 
FRACALANZA, A. P.; CAMPOS, V. C. O. Produção social do espaço urbano e conflitos pela água na Região Metropolitana de São Paulo. São Paulo em perspectiva, v. 20, n. 2, p. 32-45, 2006.

FRACALANZA, A. P. Gestão das águas no Brasil: rumo à governança da água? In: RIBEIRO, W.C. (Org.) Governança da água no Brasil: uma visão interdisciplinar. $1^{\text {a }}$ edição. São Paulo: Annablume; Fapesp; CNPq, 2009. p. 135-154.

GARCIAS, C. M.; AFONSO, J. A. C. Revitalização de rios urbanos. Revista Eletrônica e Tecnologias Ambientais - GESTA, v. 1, n. 1, p. 131-144, 2013.

GOMES, J. L.; BARBIERI, J. C. Gerenciamento de recursos hídricos no Brasil e no estado de São Paulo: um novo modelo de política pública. Cadernos ABAPE.BR, Rio de Janeiro, v. 2, n. 3, p. 01-21, 2004.

GIATTI, L. L.; ROCHA, A. A.; SANTOS, F. A.; BITENCOURT, S. C.; PIERONI, S. R. M. Condições de saneamento básico em Iporanga, Estado de São Paulo. Revista de Saúde Pública, São Paulo, v. 38, n. 4, p. 571-577, 2004.

GIL, A. C. Métodos e técnicas de Pesquisa Social, São Paulo: Editora Atlas, 2007.

GODOY, A. S. Introdução à pesquisa qualitativa e suas possibilidades. Revista de Administração de Empresas, São Paulo, v. 35, n. 2, p. 57-63, 1995.

GOLDENSTEIN, S.; SALVADOR, Z. Sustentabilidade da gestão da água e desenvolvimento sustentável. In: DOWBOR, L; A TAGNIN, R. (Org.). Administrando a água como se fosse importante: Gestão ambiental e sustentabilidade. São Paulo: Senac São Paulo, 2005, p. 8997.

GORSKI, M. C. B. Rios e cidades: ruptura e reconciliação. São Paulo: Editora Senac São Paulo, 2010.

GRABOW, W. O. B. Waterborne diseases: Update on water quality assessment and control. Water S. A., v. 22, n. 2, p. 196-202, 1996.

GUZZO, M. A. D. A habitação popular em São Paulo entre 1980-1940. Revista do Arquivo Municipal de São Paulo. São Paulo, v. 205, p. 59-74, 2014.

HILL, R. Rio Tâmisa: Londres, Inglaterra. In: MACHADO, A. T. G. M.; LISBOA, A. H.; ALVES, C. B. M.; LOPES, D. A.; GOULART, E. M. A.; LEITE, F. A.; POLIGNANO, M. V. (Org.). Revitalização de rios no mundo: América, Europa e Ásia. Belo Horizonte: Instituto Guaicuy, 2010, p. 131-152.

HIRATA, R.; FERREIRA, L. M. R. Os aquíferos da Bacia Hidrográfica do Alto Tietê: disponibilidade hídrica e vulnerabilidade à poluição. Revista Brasileira de Geociências, v. 31, n. 1, p. 43-50, 2001. 
IBGE - Instituto Brasileiro de Geografia e Estatística. Disponível em: <http://www.ibge.gov.br/home/>. Acesso em: 17/09/2016.

JACOBI, P. R. A gestão participativa de bacias hidrográficas no Brasil e os desafios do fortalecimento de espaços públicos colegiados. In: COELHO, V. S. P.; NOBRE, M. (Orgs.). Participação e deliberação: Teoria demogrática e experiências institucionais no Brasil contemporâneo. São Paulo: Editora 34, 2004, p. 270-289.

JACOBI, P. R. Comitês de bacias hidrográficas: o que está em jogo na gestão compartilhada e participativa. In: DOWBOR, L; A TAGNIN, R. (Org.). Administrando a água como se fosse importante: Gestão ambiental e sustentabilidade. São Paulo: Senac São Paulo, 2005, p. 81-88.

JACOBI, P. Dilemas socioambientais na gestão metropolitana: do risco à busca da sustentabilidade urbana. Revista de Ciências Sociais - Política \& Trabalho, n. 25, p. 115$134,2006$.

JACOBI, P. R. São Paulo metrópole insustentável - como superar esta realidade? Cadernos Metrópole, São Paulo, v. 15, n. 29, p. 219-239, 2013.

JACOBI, P. R.; SILVA-SANCHEZ, S.; FRACALANZA, A. P. Gobernanza del agua em la ciudad de São Paulo: actores sociales, degradación socioambiental y acciones públicas innovadoras. América Latina Hoy, v. 69, p. 35-51, 2015a.

JACOBI, P. R.; CIBIM, J.; LEÃO, R. S. Crise hídrica na Macropetrópole Paulista e Respostas da sociedade civil. Estudos Avançados, v. 29, n. 84, p. 27-42, 2015 b.

JANNUZZI, P. M. São Paulo, século XXI: a maior metrópole das Américas. Ciência Cultural, São Paulo, v. 5, n. 2, p. 30-32, 2004.

JORGE, J. São Paulo das enchentes, 1890-1940. Revista Eletrônica do Arquivo Público de São Paulo. São Paulo, n. 47, 2011.

JORGE, J. Rios e saúde na cidade de São Paulo, 1890-1940. História e Pespectivas, Uberlância, v. 47, p. 103-124, 2012.

KEINERT, T. M. M. Planejamento governamental e políticas públicas: a estratégia "cidades saudáveis”. Revista Saúde e Sociedade, São Paulo, v. 6, n. 2, p. 55-64, 1997.

LANDER, R. L.; LANDER, A. G.; HOUGHTON, L.; WILLIAMS, S. M.; COSTARIBEIRO, H.; BARRETO, D. L.; MATTOS, A. P.; GILSON, R. S. Factors influencing growth and intestinal parasitic infections in preschoolers attending philanthropic daycare centers in Salvador, Northeast Region of Brazil. Cadernos de Saúde Pública, Rio de Janeiro, v. 28, n. 11, p. 2177-2188, 2012. 
LAYRARGUES, P. P. Muito além da natureza: educação ambiental e reprodução social. In: LOUREIRO, LAYRARGUES E CASTRO (Org.): Pensamento Complexo, dialética e Educação Ambiental. São Paulo: Cortez, 2006.

LIBÂNIO, P. A. C.; CHERNICHARO, C. D. L.; NASCIMENTO, N. D. O. A dimensão da qualidade de água: avaliação da relação entre indicadores sociais, de disponibilidade hídrica, de saneamento e de saúde pública. Engenharia Sanitária e Ambiental, Brasil, v. 10, n. 3, p. 219-228, 2005.

LUDWIG, K. M.; FREI, F.; ALVARES FILHO, F.; RIBEIRO-PAES, J. T. Correlação entre condições de saneamento básico e parasitoses intestinais na população de Assis, Estado de São Paulo. Revista da Sociedade Brasileira de Medicina Tropical, v. 32, n. 5, 1999.

LUCENA, A. F. As políticas públicas de saneamento básico no Brasil: reformas institucionais e investimentos governamentais. Revista Plurais (Online), vol. 1, p. 117-130, 2006. Disponível em http://www.nee.ueg.br/seer/index.php/revistaplurais/article/viewFile/71/98. Acesso em: 23/12/2015.

MACEDO, G. R.; CALLISTO, M.; MAGALHÃES JR., A. P. Restauração de cursos d'água em áreas urbanizadas: perspectivas para a realidade brasileira. Revista Brasileira de Recursos Hídricos, Brasil, v. 16, n. 3, p. 127-139, 2011.

MAIA, F. P. Melhoramentos de São Paulo. $2^{\text {a }}$ edição. São Paulo: Imprensa Oficial do Estado S/A, 2010, 416 p.

MALIK, A. M. Cidades saudáveis: estratégia em aberto. Revista Saúde e Sociedade, São Paulo, v. 6, n. 2, p. 19-30, 1997.

MARCONDES, N; ANDRADE, M F. A história se repete. Como tragédia ou como comédia?. In: DOWBOR, L; A TAGNIN, R. Administrando a água como se fosse importante: Gestão ambiental e sustentabilidade. São Paulo: Senac São Paulo, 2005. Parte 1, Cap. 6. p. 73-79.

MARCONI, M. A.; LAKATOS, E. M.. Fundamentos de metodologia científica. 5. ed. São Paulo: Atlas, 2003. 311 p.

MARICATO, E. Exclusão social e reforma urbana. Revista da FASE, Rio de Janeiro, v. 62, p. 51-56, 1994.

MARICATO, E. Metrópole, legislação e desigualdade. Revista Estudos Avançados, São Paulo, v. 17, n. 48. p. 151-166, 2003.

MARICATO, E. et al. Crise urbana, produção do habitat e doença. In: SALDIVA, P. et al. Meio ambiente e saúde: o desafio das metrópoles. São Paulo: Ex Libris, 2010. cap. 3, p. 4665 . 
MARQUES, E.; REQUENA, C. O centro voltou a crescer? Trajetórias demográficas diversas e heterogeneidade na São Paulo dos anos 2000. Novos Estudos - CEBRAP, n. 95, p. 17-37, 2013.

MASCARENHAS, R. S. História da saúde pública no Estado de São Paulo. Revista Saúde Pública, São Paulo, v. 40, n. 1, p. 3-19, 2006.

MASSARA, V. M. A implantação de infraestrutura na cidade de São Paulo: o centro expandido no período 1890-1999. Revista Outros Tempos - Dossiê história e cidade, v. 9, n. 13, p. 228-251, 2012.

MATHIAS, A. Cidades e comunidades saudáveis: participação social e desenvolvimento de políticas públicas saudáveis. In: Organização Pan-Americana de Saúde (OPAS). Políticas integradas em rede e a construção de espaços saudáveis: boas práticas para a iniciativa do Rostos, Vozes e Lugares. Brasília, OPAS, 2010, p. 89-92.

MENDES, E. V. Um novo paradigma sanitário: a produção social da saúde. In: Uma agenda para a saúde. São Paulo: Hucitec, 1996. p. 233-300.

MENDES, R. Cidades saudáveis no Brasil e os processos participativos: os casos de Jundiaí e Maceió. 2000. Tese (Doutorado em Serviços de Saúde Pública) - Faculdade de Saúde Pública, Universidade de São Paulo, São Paulo, 2000.

MEYER, R. M. P.; GALVÃO, R. F. P.; LONGO, M. R. São Paulo e suas escalas de urbanização: cidade, metrópole e macrometrópole. Revista Iberoamericana de Urbanismo, n. 12, p. 7-31, 2015.

MINISTÉRIO DO MEIO AMBIENTE - MMA. Sistema Nacional de Gerenciamento de Recursos Hídricos. 2016. Disponível em: http://www.mma.gov.br. Acesso em: 20/12/2017.

MONTALI, L. Região Metropolitana de São Paulo: expansão e heterogeneidade. Anais: Encontros Nacionais da ANPUR, v. 4, 1991.

MONTEIRO, C. A.; CHIEFFI, P. P.; BENICIO, M. H. D’A.; DIAS, R. M. S.; TORRES, D. M. A. G. V.; MANGINI, A. C. S. Estudo das condições de saúde das crianças do município de São Paulo (Brasil), 1984/1985: VII - parasitoses intestinais. Revista de Saúde Pública, São Paulo, v. 22, n. 1, p. 8-15, 1988.

MONTEIRO, C. A.; NAZÁRIO, C. L. Evolução de condicionantes ambientais da saúde na infância na cidade de São Paulo (1984-1996). Revista de Saúde Pública, São Paulo, v. 34 (6 Supl), p. 13-18, 2000.

MORAES, D. S. L.; JORDÃO, B. Q. Degradação de recursos hídricos e seus efeitos sobre a saúde humana. Revista de Saúde Pública, v. 36, n. 3, p. 370-374, 2002. 
MORETTI, R. S. Recuperação de cursos d'água e terrenos de fundo de vale urbanos: a necessidade de uma ação integrada. Revista Bioikos, v. 19, n. 1 e 2, p. 17-22, 2005.

NATIONAL RESEARCH COUNCIL. Restoration of aquatic ecosystems: Science, tecnology, dan public policy. Nacional Academy Press, USA, 1992, 575 p. Disponível em: <http://www.nap.edu/catalog/1807.html>. Acesso em: 20 mar. 2017.

OLIVEIRA, A. B. K. de. O rio Tietê: o processo histórico e sua importância para São Paulo. I Simpósio Mineiro de Geografia: das diversidades à articulação geográfica. Universidade Federal de Alfenas, Minas Gerais. 2014.

OLIVEIRA FILHO, G. R. A crise da água na região metropolitana de São Paulo em 2014 e a ineficiente gestão dos recursos hídricos. CES REVISTA, Juiz de Fora, v. 29, n. 1, p. 05-20, 2015.

Organização Mundial da Saúde - OMS. Veinte pasos para desarrollar um proyecto de ciudades saludables. $2^{a}$ edição. Oficina Nacional para Europa. 1995.

PASTERNAK, S; LEME, M. C. S. De vila a metrópole. In: SALDIVA, P. et al. Meio ambiente e saúde: o desafio das metrópoles. São Paulo: Ex Libris, 2010. cap. 2, p. 22-45.

PENNA, N. A. A questão urbano ambiental: política urbana e gestão da cidade. Anais: Encontros Nacionais da ANPUR, v. 10, 2013.

PEREIRA, L. C. S.; PIRES, L. P. São Paulo: o nascimento de uma metrópole. Revista Historiador, n. 1, p. 21-31, 2008.

PINTO, A. L. A.; AMARAL, R.; HONÓRIO, R. F. Recuperação de áreas degradadas no município de São Paulo: projeto-piloto Jd. Walquíria. VI Simpósio Nacional de Geomorfologia/ Regional Conference on Geomorphology. Goiânia, 2006.

PIZZELA, D. G. A relação entre Planos Diretores Municipais e Planos de Bacias Hidrográficas na gestão hídrica. Revista Ambiente \& Água. Taubaté, v. 10, n. 3, p. 636-645, 2015.

POMPEU, C. T. Direito de Águas no Brasil. $2^{\mathrm{a}}$ edição. São Paulo: Editora Revista dos Tribunais, 2010.

PORTO, M. F. A.; PORTO, R. L. Gestão de Bacias Hidrográficas, Estudos Avançados, v. 22 , n. 63, p. 43-60, 2008.

RAMIRES JR., S. P.; NEVES, S. S.; RUIZ, M. S.; GALLARDO, A. L. C. F.; CORTES, P. L.; CERÂNTOLA, A. P. C. Governança colaborativa aplicada à gestão de conflitos socioambientais na despoluição de córregos na cidade de São Paulo. Revista Brasileira de Gestão e Desenvolvimento Regional, Taubaté/SP, v. 11, n. 1, p. 113-134, 2015. 
REZENDE, V. F. Política urbana ou política ambiental, da Constituição de 88 ao Estatuto da Cidade. In: RIBEIRO, L. C. Q.; CARDOSO, A. L. Reforma urbana e gestão democrática: promessas e desafios do Estatuto da Cidade. $1^{\text {a }}$ edição. Rio de Janeiro: Revan: FASE, 2003. p. $139-152$.

RIBEIRO, W.C. (Org.). Impasses da governança da água no Brasil. In: Governança da água no Brasil: uma visão interdisciplinar. $1^{\text {a }}$ edição. São Paulo: Annablume; Fapesp; CNPq, 2009. p. 111-134.

RODRIGUES, F. A. Os caminhos das águas. Agroanalysis, v. 18, n. 3, p. 23-26, 1998.

ROLNIK, R.; KOWARIK, L.; SOMEKH, N. (ed.); AMARAL, A. L. A. (redação final). São Paulo: crise e mudança. São Paulo: Brasiliense, 1990. 215 p.

ROLNIK, R. O que é cidade. $3^{\text {a }}$ edição. São Paulo: Brasiliense, 1994. 86 p.

ROLNIK, R. A cidade e a lei: legislação, política urbana e territórios na cidade de São Paulo. $3^{\text {a }}$ edição São Paulo: Studio Nobel, 2003. 272 p.

SABESP - Companhia de Saneamento Básico de São Paulo. Relatório da Administração 2016. Disponível em: <http://www.sabesp.com.br/sabesp/filesmng.nsf/D6D9B27AC219B6E C832580F1000BFE09/\$File/RelatorioAdministracao.pdf>. Acesso em: 21 de abr. 2017.

SABESP - Companhia de Saneamento Básico de São Paulo. Dados do Relatório de Sustentabilidade 2007. 2007. Disponível em: <http://www2.sabesp.com.br/sustentabilidade2007/relatorio_sustentabilidade_2007.pdf>. Acesso em: 21 de mar. 2015.

Dados do Relatório de Sustentabilidade 2009. 2009. Disponível em: <http://site.sabesp.com.br/uploads/file/sociedade_meioamb/RS_2009_Portugues.pdf>. Acesso em: 21 de mar. 2015.

Dados do Relatório de Sustentabilidade 2011. 2011. Disponível em: <http://site.sabesp.com.br/uploads/file/asabesp_doctos/relatorio_sustentabilidade2011.pdf>. Acesso em: 21 de mar. 2015.

Dados do Relatório de Sustentabilidade 2012. 2012 Disponível em: <http://site.sabesp.com.br/uploads/file/asabesp_doctos/sabesp_rs_2012_portugues.pdf >. Acesso em: 21 de mar. 2015.

. Dados do Relatório de Sustentabilidade 2013. 2013a. Disponível em: <http://site.sabesp.com.br/uploads/file/sociedade_meioamb/rs_2013_portugues.pdf>. Acesso em: 21 de mar. 2015. 
_. Relatório da Administração 2012. 2013b. Disponível em: <http://empresaspublicas.imprensaoficial.com.br/balancos/sabesp/sabesp2013.pdf>. Acesso em: 21 de abr. 2017.

Dados do Relatório de Sustentabilidade 2014. 2014. Disponível em: $<$ http://site.sabesp.com.br/uploads/file/sociedade_meioamb/rs_2014.pdf >. Acesso em: $10 \mathrm{de}$ nov. 2015.

Proposta renovação outorga Sistema Cantareira. 2015a. Disponível em: <http://arquivos.ana.gov.br/imprensa/noticias/20150817115304_SABESP\%20-\%20Complet o.pdf >. Acesso em: 10 de nov. 2015.

. CHESS - Crise hídrica, estratégia e soluções da SABESP: Para a Região Metropolitana de São Paulo. 2015b. Disponível em: < http://site.sabesp.com.br/site/uploads/file/crisehidrica/chess_crise_hidrica.pdf >. Acesso em: 10 de jan. 2017.

Dados do Relatório de Sustentabilidade 2015. 2015c. Disponível em: <http://site.sabesp.com.br/site/uploads/file/sociedade_meioamb/RS_2015_28032016.pdf>. Acesso em: 10 de jan. 2017.

_. Relatório da Administração 2016. 2017. Disponível em: < http://www.sabesp.com.br/sabesp/filesmng.nsf/D6D9B27AC219B6EC832580F1000BFE09/\$ File/RelatorioAdministracao.pdf>. Acesso em: 21 de abr. 2017.

SAMPIERI, R. H.; COLLADO, C. F.; LUCIO, P. B. Medotología dela investigación. McGraw-Hill. México, 1991.

SANT'ANNA, D. B. Vida e morte dos chafarizes na cidade de São Paulo. Revista do Arquivo Municipal de São Paulo. São Paulo, v. 203, p. 81-90, 2004.

SANTOS, M. A urbanização brasileira. 1ª edição. São Paulo: Hucitec, 1993. 157 p.

SANTOS, F. A. Domando as águas: salubridade e ocupação do espaço na cidade de São Paulo, 1875-1930. $1^{a}$ edição. São Paulo: Alameda Casa Editorial, 2011. 328 p.

SÃO PAULO (Estado). Decreto $n^{\circ} 27.576$, de 11 de novembro de 1987. Cria o Conselho Estadual de Recursos Hídricos, dispõe sobre o Plano Estadual de Recursos Hídricos e o Sistema Estadual de Gestão de Recursos Hídricos, e dá outras providências. Diário Oficial: Estado de São Paulo, São Paulo, SP, 12 nov. 1987. Seção 1, p. 02.

Lei $\mathrm{n}^{\circ}$ 6.134, de 02 de junho de 1988. Dispõe sobre a preservação dos depósitos naturais de águas subterrâneas do Estado de São Paulo, e dá outras providências. Diário Oficial: Estado de São Paulo, São Paulo, SP, 03 jun. 1988, v. 98, n. 101, p. 01. 
Decreto $\mathrm{n}^{\circ}$ 32.955, de 7 de fevereiro de 1991a. Regulamenta a Lei $\mathrm{n}^{\circ} 6.134$, de 2 de junho de 1988. Diário Oficial: Estado de São Paulo, São Paulo, SP, 08 fev. 1991. Seção 1, p. 07.

Decreto $\mathrm{n}^{\circ}$ 32.954, de 7 de fevereiro de 1991b. Dispõe sobre a aprovação do Primeiro Plano Estadual de Recursos Hídricos - PERH 90/91 e dá outras providências. Diário Oficial: Estado de São Paulo, São Paulo, SP, 08 fev. 1991. Seção 1, p. 01.

Decreto $\mathrm{n}^{\circ}$ 36.787, de 18 de maio de 1993. Adapta o Conselho Estadual de Recursos Hídricos - CRH e o Comitê Coordenador do Plano Estadual de Recursos Hídricos - CORHI, criados pelo Decreto $\mathrm{n}^{\circ}$ 27.576, de 11 de novembro de 1987, às disposições da Lei $\mathrm{n}^{\circ} 7.663$, de 30 de dezembro de 1991. (*) Redação alterada pelos Decretos: 38.455, de 21/03/94; Decreto 39.742, de 23/12/94 e Decreto 43.265, de 30/06/98. Diário Oficial: Estado de São Paulo, São Paulo, SP, 19 mai. 1993. Seção 1, p. 04.

Lei $\mathrm{n}^{\circ}$ 9.034, de 27 de dezembro de 1994. Dispõe sobre o Plano Estadual de Recursos Hídricos - PERH, a ser implantado no período 1994 e 1995, em conformidade com a Lei $\mathrm{n}^{\circ}$ 7.663, de 30/12/91, que instituiu normas de orientação à Política Estadual de Recursos Hídricos. Diário Oficial: Estado de São Paulo, São Paulo, SP, 28 dez. 1994. Seção 1, p. 3.

Lei $\mathrm{n}^{\circ}$ 9.866, de 28 de novembro de 1997. Dispõe sobre diretrizes e normas para a proteção e recuperação das bacias hidrográficas dos mananciais de interesse regional do Estado de São Paulo e dá outras providências. Diário Oficial: Estado de São Paulo, São Paulo, SP, 29 nov. 1997. Seção 1, p. 1-3.

Decreto $\mathrm{n}^{\circ}$ 43.022, de 7 de abril de 1998. Regulamenta dispositivos relativos ao Plano Emergencial de Recuperação dos Mananciais da Região Metropolitana da Grande São Paulo, de que trata a Lei ${ }^{\circ}$ 9.866, de 28 de novembro de 1997, que dispõe sobre diretrizes e normas para a proteção e a recuperação dos mananciais de interesse regional do Estado de São Paulo e dá outras providências correlatas. Diário Oficial: Estado de São Paulo, São Paulo, SP, 08 abr. 1998. Seção 1, p. 01.

Decreto $\mathrm{n}^{\circ}$ 48.896, de 26 de agosto de 2004. Regulamenta o Fundo Estadual de Recursos Hídricos - FEHIDRO, criado pela Lei n ${ }^{\circ}$ 7.663, de 30 de dezembro de 1991, alterada pela Lei no 10.843, de 5 de julho de 2001. Diário Oficial: Estado de São Paulo, São Paulo, SP, 27 ago. 2004. Seção 1, p. 03.

Lei $\mathrm{n}^{\circ}$ 12.300, de 16 de março de 2006. Institui a Política Estadual de Resíduos Sólidos e define princípios e diretrizes. Diário Oficial: Estado de São Paulo, São Paulo, SP, 17 mar. 2006. Seção 1, p. 01.

Decreto $\mathrm{n}^{\circ}$ 57.113, de 07 de julho de 2011. Adapta o Conselho Estadual de Recursos Hídricos - CRH e o Comitê Coordenador do Plano Estadual de Recursos Hídricos - CORHI, 
criados pelo Decreto $\mathrm{n}^{\circ}$ 27.576, de 1987, às disposições da Lei $\mathrm{n}^{\circ} 7.663$, de 1991. Diário Oficial: Estado de São Paulo, São Paulo, SP, 08 jul. 2011. Seção 1, p. 03.

Secretaria do Meio Ambiente. Plano de resíduos sólidos do estado de São Paulo. $1^{\circ}$ edição. São Paulo: SMA, 2014, 350 p.

Lei $\mathrm{n}^{\circ}$ 16.050, de 31 de julho de 2014. Aprova a Política de Desenvolvimento Urbano e o Plano Diretor Estratégico do Município de São Paulo e revoga a Lei ${ }^{\circ}$ 13.430/2002. Diário Oficial: Estado de São Paulo - Fernando Haddad - Prefeito, São Paulo, SP, 1 ago. 2014, nº 140, Ano 59.

Lei $\mathrm{n}^{\circ}$ 16.337, de 14 de dezembro de 2016. Dispõe sobre o Plano Estadual de Recursos Hídricos - PERH e dá providências correlatas. Diário Oficial: Estado de São Paulo, São Paulo, SP, 15 dez. 2016. Seção 1, p. 01.

SEADE - Fundação Sistema Estadual de Análise de Dados. Disponível em: http://www.seade.gov.br/. Acesso em: 15/02/2017.

SER - Society for Ecological Restoration. The SER primer on ecological restoration. Society for Ecological Restoration Science \& Policy Working Group, p. 1-9, 2002.

SETTI, A. A.; LIMA, J. E. F. W.; CHAVES, A. G. M.; PEREIRA, I. C. Introdução ao Gerenciamento de Recursos Hídricos. $2^{\circ}$ edição. Brasília: Agência Nacional de Energia Elétrica, Superintendência de Estudos e Informações Hidrológicas, 2001.

SIGRH - Sistema Integrado de Gerenciamento de Recursos Hídricos do Estado de São Paulo. Apresentação. 2015. Disponível em: <http://www.sigrh.sp.gov.br/fabhat/apresentacao>. Acesso em: 17/12/2015.

SIGRH - Sistema Integrado de Gerenciamento de Recursos Hídricos do Estado de São Paulo. Conselho de Orientação do Fundo Estadual de Recursos Hídricos. Relatório de Atividades do FEHIDRO $\quad$ - 2016.2016 .2 Disponível em: <http://www.sigrh.sp.gov.br/cofehidro/relatoriosanuaisdeatividades>. Acesso em: 10/05/2017.

SNIS - Sistema Nacional de Informações sobre Saneamento. Diagnóstico Anual de Água e Esgotos 2014. Disponível em: <http://www.snis.gov.br/diagnostico-agua-e-esgotos>. Acesso em: 10/05/2017.

SNIS - Sistema Nacional de Informações sobre Saneamento. Diagnóstico Anual de Água e Esgotos 2015. Disponível em: <http://www.snis.gov.br/diagnostico-agua-e-esgotos>. Acesso em: 10/05/2017.

SILVA, L. J. Crescimento urbano e doença: a esquistossomose no município de São Paulo (Brasil). Revista de Saúde Pública, São Paulo, v. 19, n. 1, p. 1-7, 1985. 
SILVA, R.T.; PORTO, M.F.A. Gestão urbana e gestão das águas: caminhos da integração. Estudos Avançados, São Paulo, v. 17, n. 47, p. 129-145, 2003.

SILVA, M. T. N.; PONTES, A.; ARAGÃO, P.; ANDRADE, J.; TAVARES-NETO, J. Prevalência de parasitas intestinais em crianças, com baixos indicadores sócio-econômicos, de Campina Grande (Paraíba). Revista Baiana de Saúde Pública, Bahia, v. 29, n. 1, p. 121-125, 2005.

SILVA, E. L.; MENEZES, E. M. Metodologia da pesquisa e elaboração de dissertação. $4^{\mathrm{a}}$ edição. Florianópolis: UFSC, 2005.

SILVA, J. C. A. Recuperação de córregos urbanos através do controle de cargas pontuais e difusas. Estudo de caso: córrego Ibiporã e do Sapé. Dissertação (Mestrado) Escola Politécnica da Universidade de São Paulo. Departamento de Engenharia Hidráulica e Ambiental, São Paulo, 2014.

SILVA, E. A. Despoluição do rio Tietê: questionar paradigmas para avançar. Dissertação (Mestrado) - Universidade Federal do ABC. Departamento de Planejamento e Gestão do Território, Santo André, 2016.

SILVA-SÁNCHEZ, S.; JACOBI, P. R. Implementation of Riverside parks in the city of São Paulo - progress and constraints. Local Environment, v. 21, n. 1, p. 65-84, 2016.

SPERANDIO, A. M. G.; FRANSCISCO FILHO, L. L.; MATTOS, T. P. Política de promoção da saúde e planejamento urbano: articulações para o desenvolvimento da cidade saudável. Ciência \& Saúde Coletiva, v. 21, n. 5, p. 1931-1937, 2016.

SPOSATI, A. O. Cidade em Pedaços: São Paulo: Brasiliense, 2001. 176 p.

SUZIGAN, W. A industrialização de São Paulo: 1930 - 1945. Revista Brasileira de Economia, Rio de Janeiro, v. 25, p.89-111, 1971.

TOLEDO, B. L. São Paulo, três cidades em um século. $3^{\text {a }}$ edição. São Paulo: Cosac Naify, 2004. $192 \mathrm{p}$.

TRAVASSOS, L. R. F. C.; GROSTEIN, M. D. A ocupação de fundos de vale urbanos em São Paulo e sua dimensão sócio-ambiental. Anais: Encontros Nacionais da ANPUR, v. 10, 2013.

TRAVASSOS, L.; SCHULT, S. I. M. Recuperação socioambiental de fundos de vale urbanos na cidade de São Paulo, entre transformações e permanências. Caderno Metrópole, São Paulo, v. 15, n. 29, p. 289-312, 2013.

TRAVASSOS, L. Cidade e água em São Paulo: a origem de um modelo de urbanização. XVI ENANPUR - Espaço, Planejamento \& Insurgência. Sessões Temáticas - Trajetórias das ideias, representações e experiências urbanísticas. Belo Horizonte, 2015. 
TZORTZIZ, P. S.; KNIESS, C. T. Programa de despoluição de córregos: Programa Córrego Limpo. Revista Inovação, Projetos e Tecnologias - IPTEC, São Paulo, v. 4, n. 1, p. 114$128,2016$.

VERAS, M. P. B. Tempo e espaço na metrópole: breves reflexões sobre assincronias urbanas. São Paulo em perspectiva, v. 15, n. 1, p. 3-12, 2001.

WESTPHAL, M. F. Municípios saudáveis: aspectos conceituais. Revista Saúde e Sociedade, São Paulo, v. 6, n. 2, p. 9-18, 1997.

YASSUDA, E.R. Gestão de recursos hídricos: fundamentos e aspectos institucionais. Revista Administração Pública, v.27, n.2, p.5-18, 1993.

ZAGATTO, P. A.; LORENZETTI, M. L.; LAMPARELli, M. C.; SALVADOR, M. E. P.; MENEGON JR., N.; BERTOLETTI, E. Aperfeiçoamento de um índice de qualidade de águas. Acta Limnilogica Brasiliensia, v. 111, n. 2, p. 111-126, 1999.

ZANETI, I. C. B. B.; SÁ, L. M. A educação ambiental como instrumento de mudança na concepção de gestão dos resíduos sólidos domiciliares e na preservação do meio ambiente. Encontro da Associação Nacional de Pós-Graduação e Pesquisa em Ambiente e Sociedade, v. 1, 2002. 
Quadro 1 - Assuntos relevantes do ano 1994.

\begin{tabular}{|c|c|l|}
\hline Data & Tema & \multicolumn{1}{c|}{ Detalhamento } \\
\hline \multirow{1}{*}{$14 / 12 / 1994$} & Energia & $\begin{array}{l}\text { Comentário com objetivo de nivelar o conhecimento sobre o assunto. Usina } \\
\text { Henry Borden não está produzindo o total de sua capacidade de energia } \\
\text { elétrica e foi solicitado aumento do bombeamento para evitar racionamento. }\end{array}$ \\
\cline { 2 - 3 } & Planão & $\begin{array}{l}\text { Plano de Gestão de Integração das três bacias - Alto Tietê, Piracicaba e } \\
\text { Baixada Santista - elaborado pela empresa HIDROPLAN. Pesquisas } \\
\text { estavam sendo feitas para a criação do plano. }\end{array}$ \\
\cline { 2 - 3 } & Contaminação & $\begin{array}{l}\text { Contaminação com resíduos tóxicos de área da barragem de Taiaçupeba } \\
\text { pela empresa Manikraft. }\end{array}$ \\
\cline { 2 - 3 } & Subcomitês & Formação de subcomitês e câmaras técnicas. \\
\hline
\end{tabular}

Fonte: Sistema Integrado de Gerenciamento de Recursos Hídricos, compilado pela autora. 
Quadro 2 - Assuntos relevantes do ano 1995.

\begin{tabular}{|c|c|c|}
\hline Data & Tema & Detalhamento \\
\hline \multirow{2}{*}{$22 / 02 / 1995$} & Inundações & $\begin{array}{l}\text { Reunião foi marcada diante dos percalços com inundações que estavam } \\
\text { ocorrendo na região, onde representantes de diversos locais puderam expor } \\
\text { seus problemas. }\end{array}$ \\
\hline & $\begin{array}{c}\text { Área de Proteção } \\
\text { Ambiental }\end{array}$ & $\begin{array}{l}\text { Tratou-se da regularização da várzea do rio Tietê, que seria possível a } \\
\text { ocupação racional da várzea para sua preservação e utilização como medida } \\
\text { não estrutural no combate às enchentes. }\end{array}$ \\
\hline \multirow{9}{*}{ 19/09/1995 } & $\begin{array}{l}\text { Criação de } \\
\text { subcomitês }\end{array}$ & $\begin{array}{l}\text { Devido à complexidade da região e as características próprias de cada local } \\
\text { (havendo as sub-bacias), entrou em pauta a necessidade de se pensar na } \\
\text { criação de comitês para as sub-bacias. (Intervenção do secretário interino da } \\
\text { SRHSO, Dr. Waldemar S. Casadei) }\end{array}$ \\
\hline & $\begin{array}{l}\text { Recursos } \\
\text { financeiros }\end{array}$ & $\begin{array}{l}\text { Levantou-se que apesar dos esforços dos comitês de desenvolver projetos, } \\
\text { os mesmos não possuem recursos para tal finalidade. (Intervenção do } \\
\text { secretário interino da SRHSO, Dr. Waldemar S. Casadei) }\end{array}$ \\
\hline & Despoluição & $\begin{array}{l}\text { Foi colocado que o comitê ainda não havia tomado conhecimento oficial do } \\
\text { Programa de Despoluição do Rio Tietê. (Intervenção do secretário interino } \\
\text { da SRHSO, Dr. Waldemar S. Casadei) }\end{array}$ \\
\hline & Inundações & $\begin{array}{l}\text { Ofício de solicitação da Comissão Técnica de Controle de Cheias do } \\
\text { Córrego Pirajussara para formação de fórum da Bacia do Córrego } \\
\text { Pirajussara. }\end{array}$ \\
\hline & $\begin{array}{l}\text { Degradação } \\
\text { florestal }\end{array}$ & $\begin{array}{l}\text { Dissertou sobre ação movida pelo Ministério Público contra o empresário } \\
\text { dono da revista IstoÉ, cuja empresa devastou florestas e degradou áreas. } \\
\text { Por força da lei foi obrigado a recuperar toda a área. (Intervenção do } \\
\text { Procurador da Justiça do Ministério Público de São Paulo, Dr. Edivon } \\
\text { Teixeira) }\end{array}$ \\
\hline & $\begin{array}{c}\text { Lei de Proteção } \\
\text { de Mananciais }\end{array}$ & $\begin{array}{l}\text { Destaca-se a necessidade do comitê participar das discussões e da revisão } \\
\text { da lei, propondo a criação de uma Câmara Técnica. (Representante da } \\
\text { SMA, Dra. Neusa Marcondes) }\end{array}$ \\
\hline & $\begin{array}{l}\text { Programas } \\
\text { prioritários }\end{array}$ & $\begin{array}{l}\text { Sugeriu-se que os projetos prioritários para investimentos no Plano } \\
\text { Estadual de Recursos Hídricos } 96 / 99 \text { fossem aqueles já existentes ou em } \\
\text { andamento pelo Governo do Estado como, por exemplo: Projeto Tietê, } \\
\text { Guarapiranga, revisão da Lei de Proteção dos Mananciais, questões da } \\
\text { Billings e os projetos da SABESP. (Secretaria Executiva e presidente do } \\
\text { CBH-AT, Hélio Rubens Figueiredo) }\end{array}$ \\
\hline & Planão/ Billings & $\begin{array}{l}\text { Apresentou-se as alternativas analisadas para sanar os problemas da } \\
\text { Billings baseados nos seus possíveis usos, tendo } 7 \text { alternativas analisadas } \\
\text { pela empresa HIDROPLAN. (Engenheiro do Consórcio HIDROPLAN, } \\
\text { André Luiz) }\end{array}$ \\
\hline & Poluição & $\begin{array}{l}\text { O município Pirapora do Bom Jesus estava passando por momentos difíceis } \\
\text { com a ida de água poluída e com espuma do rio Tietê, prejudicando a saúde } \\
\text { dos moradores da cidade. (Prefeito de Pirapora do Bom Jesus, Raul } \\
\text { Silveira) }\end{array}$ \\
\hline 26/10/1995 & Planão/ Billings & $\begin{array}{l}\text { Abriu-se a reunião para debates sobre o relatório das alternativas propostas } \\
\text { pela empresa HIDROPLAN para a represa Billings. }\end{array}$ \\
\hline
\end{tabular}


Quadro 2 - Assuntos relevantes do ano 1995.

\section{Continuação}

\begin{tabular}{|c|c|l|}
\hline Data & Tema & \multicolumn{1}{c|}{ Detalhamento } \\
\hline \multirow{2}{*}{$26 / 10 / 1995$} & $\begin{array}{c}\text { Despoluição e } \\
\text { população }\end{array}$ & $\begin{array}{l}\text { Destacou-se que está em andamento o Projeto Tietê, que visa melhorar a } \\
\text { qualidade das águas dos rios Tietê e Pinheiros e a necessidade de existir um } \\
\text { acordo com a sociedade civil para a minimização dos problemas da má } \\
\text { qualidade da água. (Secretário da SRHSO, Eng. Hugo Marques da Rosa) }\end{array}$ \\
\cline { 2 - 3 } & Sespoluição & $\begin{array}{l}\text { Trataram sobre a despoluição da represa Billings e do rio Tietê, exaltando a } \\
\text { necessidade de trabalhar de forma conjunta, integrando os temas. }\end{array}$ \\
\cline { 2 - 4 } & Saneamento & $\begin{array}{l}\text { A discussão sobre a melhoria da qualidade das águas de mananciais girou } \\
\text { entorno da urgência em aumentar o tratamento de esgoto e da implantação } \\
\text { de novas centros de tratamento de esgoto. Ainda foi colocado que não seria } \\
\text { possível alcançar 100\% de esgoto tratado, mesmo depois da conclusão do } \\
\text { Projeto de Despoluição do Tietê devido as dificuldades técnicas. }\end{array}$ \\
\hline \multirow{2}{*}{ Despoluição } & $\begin{array}{l}\text { Projeto de Despoluição da Bacia do Tietê; } \\
\text { Obras de aproveitamento múltiplo e obras de coleta; } \\
\text { Afastamento e tratamento dos esgotos da RMSP. }\end{array}$ \\
\hline
\end{tabular}

Fonte: Sistema Integrado de Gerenciamento de Recursos Hídricos, compilado pela autora. 
Quadro 3 - Assuntos relevantes do ano 1996.

\begin{tabular}{|c|c|c|}
\hline Data & Tema & Detalhamento \\
\hline \multirow{5}{*}{ 03/04/1996 } & $\begin{array}{l}\text { Lei de Proteção } \\
\text { de Mananciais }\end{array}$ & $\begin{array}{l}\text { Foram levantados temas sobre as recomendações de não executar obras } \\
\text { públicas em áreas de proteção de mananciais até a revisão da lei, o que } \\
\text { preocupa alguns prefeitos. Foi pedido que não proibissem o crescimento } \\
\text { dos municípios. Além disso, foram citadas invasões ocorridas nas áreas de } \\
\text { mananciais. }\end{array}$ \\
\hline & Inundações & $\begin{array}{l}\text { Ocorreu apresentação da síntese do relatório sobre o controle de inundações } \\
\text { na RMSP e foi dito que os itens deste trabalho já estavam sendo } \\
\text { incorporados ao Plano Diretor de Macrodrenagem. (Secretário executivo, } \\
\text { Eng. Jorge Simão Junior) }\end{array}$ \\
\hline & $\begin{array}{l}\text { Criação de } \\
\text { subcomitês }\end{array}$ & $\begin{array}{l}\text { Enfatizou a importância do comitê discutir sobre a criação de subcomitês } \\
\text { para que seja possível discutir as questões regionais nos subcomitês e levar } \\
\text { ao CBH-AT os temas já debatidos e em consenso. (Secretário da SRHSO, } \\
\text { Eng. Hugo Marques da Rosa) } \\
\text { Assunto levantou diversos questionamentos entre os presentes. }\end{array}$ \\
\hline & Inundações & $\begin{array}{l}\text { Salientou a importância de tratar do assunto de forma sistêmica e integrada, } \\
\text { com a participação dos diversos níveis do governo e sociedade civil e } \\
\text { informou que houve contato com as prefeituras do ABC para iniciar um } \\
\text { trabalho integrado para enfrentar as inundações. }\end{array}$ \\
\hline & $\begin{array}{l}\text { Plano Diretor de } \\
\text { Macrodrenagem/ } \\
\quad \text { Planão }\end{array}$ & $\begin{array}{l}\text { Informou que estava sendo formalizado um convênio com a Prefeitura do } \\
\text { Município de São Paulo, a qual alocaria recursos financeiros para o plano e } \\
\text { daria continuidade nos trabalhos feitos pela empresa HIDROPLAN } \\
\text { (Planão). }\end{array}$ \\
\hline \multirow{5}{*}{ 17/07/1996 } & Despoluição & $\begin{array}{l}\text { Apontou que os projetos de canalização que são voltados para melhoria da } \\
\text { saúde pública e controle de poluição deveriam ser avaliados em relação a } \\
\text { sua efetividade. (Representante do Instituto Vitae Civilis, Rubens Born) }\end{array}$ \\
\hline & Abastecimento & $\begin{array}{l}\text { Foram levantadas questões sobre implantações de projetos de água de reuso } \\
\text { e o aumento da captação de água para abastecimento. Além disso, pontuou- } \\
\text { se que a despoluição dos rios Tietê e Pinheiros (este por causa da água que } \\
\text { é bombeada para a represa Billings) tinham como objetivo aumentar a } \\
\text { demanda hídrica para abastecer a RMSP. }\end{array}$ \\
\hline & Erosão & $\begin{array}{l}\text { Levantou-se o tema da erosão na RMSP, colocando-a como ponto relevante } \\
\text { para a macrodrenagem da região. }\end{array}$ \\
\hline & Projeto Tietê & Foram questionados os custos do projeto. \\
\hline & $\begin{array}{l}\text { Uso e ocupação } \\
\text { do solo/ } \\
\text { Mananciais }\end{array}$ & $\begin{array}{l}\text { Discutiu-se as invasões ocorridas em alguns municípios, principalmente em } \\
\text { áreas de mananciais. Colocou-se que além de imobiliárias, pessoas estavam } \\
\text { comprando terrenos nessas áreas e outras estavam invadindo por não ter } \\
\text { onde morar. }\end{array}$ \\
\hline \multirow{3}{*}{$30 / 08 / 1996$} & $\begin{array}{l}\text { Recursos } \\
\text { financeiros }\end{array}$ & $\begin{array}{l}\text { Debateu-se as prioridades para a utilização dos recursos financeiros } \\
\text { provindos do COFIHIDRO, porém sem chegar a uma conclusão. }\end{array}$ \\
\hline & $\begin{array}{l}\text { Lei de Proteção } \\
\text { de Mananciais }\end{array}$ & $\begin{array}{l}\text { Colocou em pauta uma proposta de criar-se a lei estadual de forma } \\
\text { generalista, possibilitando a concepção de leis específicas para cada bacia } \\
\text { ou sub-bacia. (Representante da Secretaria do Meio Ambiente, Dra. Lúcia } \\
\text { de Sena) }\end{array}$ \\
\hline & Abastecimento & Houveram colocações sobre anteprojeto de cobrança da água. \\
\hline $30 / 08 / 1996$ & Projeto Billings & $\begin{array}{l}\text { Iniciou-se o Projeto Billings em conjunto com a SEMARH para tomar } \\
\text { decisões sobre como a represa se encontra e efetivar ações para a melhoria } \\
\text { da qualidade da água. (Secretário da SRHSO, Eng. Hugo Marques da Rosa) }\end{array}$ \\
\hline
\end{tabular}

Continua 
Quadro 3 - Assuntos relevantes do ano 1996.

Continuação

\begin{tabular}{|c|c|l|}
\hline Data & Tema & \multicolumn{1}{c|}{ Detalhamento } \\
\hline \multirow{1}{*}{$11 / 11 / 1996$} & $\begin{array}{c}\text { Plano } \\
\text { Metropolitano da } \\
\text { Água }\end{array}$ & $\begin{array}{l}\text { Dissertou-se sobre o programa que faz parte de outros três - Programa de } \\
\text { Redução de Perdas, Programa de Uso Racional da Água e Programa de } \\
\text { Reúso Planejado da Água, sendo o objetivo de todos os programas a maior } \\
\text { eficiência no abastecimento, principalmente na RMSP devido ap alto índice } \\
\text { de rodízio ocorrido na região. (Representante da SABESP, Eng. Orlando } \\
\text { Cassetari) }\end{array}$ \\
\cline { 2 - 3 } & Despoluição & $\begin{array}{l}\text { Foram levantadas dúvidas sobre a despoluição da represa Billings e dos rios } \\
\text { Tietê e Pinheiros. }\end{array}$ \\
\cline { 2 - 3 } & $\begin{array}{c}\text { Recursos } \\
\text { financeiros }\end{array}$ & $\begin{array}{l}\text { Debateu-se as prioridades para a utilização dos recursos financeiros } \\
\text { provindos do COFIHIDRO, porém sem chegar a uma conclusão. }\end{array}$ \\
\cline { 2 - 3 } & Abastecimento & Levantou-se as diretrizes para aumentar o abastecimento na RMSP. \\
\hline
\end{tabular}

Fonte: Sistema Integrado de Gerenciamento de Recursos Hídricos, compilado pela autora. 
Quadro 4 - Assuntos relevantes do ano 1997.

\begin{tabular}{|c|c|c|}
\hline Data & Tema & Detalhamento \\
\hline \multirow[b]{2}{*}{ 14/03/1997 } & $\begin{array}{l}\text { Criação de } \\
\text { Câmaras } \\
\text { Técnicas }\end{array}$ & $\begin{array}{l}\text { Propôs-se a criação das câmaras: I - Qualidade da água e proteção de } \\
\text { mananciais; II - Drenagem e controle de inundações; III - Quantidade e } \\
\text { racionalização dos usos da água. }\end{array}$ \\
\hline & Metas para 1997 & $\begin{array}{l}\text { Discorre-se sobre as metas almejadas para o ano, sendo estas: aprovação do } \\
\text { Plano Estadual } 96 / 99 \text {; consolidação do projeto sobre agência de bacia; e no } \\
\text { âmbito da bacia do Alto Tietê, o plano de macrodrenagem e formação dos } \\
\text { subcomitês regionais. }\end{array}$ \\
\hline \multirow[b]{2}{*}{ 23/06/1997 } & $\begin{array}{l}\text { Lei de Proteção } \\
\text { de Mananciais }\end{array}$ & $\begin{array}{l}\text { Lembrou-se que a nova lei seria votada nos próximos meses, abrindo } \\
\text { caminho para as leis específicas em cada manancial. (Secretário da } \\
\text { SRHSO, Eng. Hugo Marques da Rosa) }\end{array}$ \\
\hline & $\begin{array}{c}\text { Plano de } \\
\text { Desenvolvimento } \\
\text { e Proteção } \\
\text { Ambiental da } \\
\text { Bacia } \\
\text { Guarapiranga } \\
\end{array}$ & $\begin{array}{l}\text { Expôs o plano e esclareceu dúvidas a respeito. (Representante do Consórcio } \\
\text { CNEC-JNS - que elaborou o plano, Vera Pousada) }\end{array}$ \\
\hline 05/09/1997 & Subcomitês & $\begin{array}{l}\text { Relatou-se o processo de organização dos subcomitês da bacia: } \\
\text { Cotia/Guarapiranga, Juqueri/Cantareira e Tietê/Cabeceiras. }\end{array}$ \\
\hline
\end{tabular}

Fonte: Sistema Integrado de Gerenciamento de Recursos Hídricos, compilado pela autora. 
Quadro 5 - Assuntos relevantes do ano 1998.

\begin{tabular}{|c|c|c|}
\hline Data & Tema & Detalhamento \\
\hline \multirow{4}{*}{ 20/03/1998 } & $\begin{array}{l}\text { Programação de } \\
\text { atividades anual }\end{array}$ & $\begin{array}{l}\text { Destacou-se as seguintes atividades: consolidação dos subcomitês, trabalho } \\
\text { das Câmaras Técnicas e tramites dos projetos financiados com os recursos } \\
\text { do FEHIDRO. }\end{array}$ \\
\hline & Plano de Bacia & $\begin{array}{l}\text { Atentou sobre a necessidade de elaborar o Plano da Bacia para o período } \\
2000 \text { - 2003. (Secretário Executivo do comitê, Eng. Hugo Marques da } \\
\text { Rosa) }\end{array}$ \\
\hline & $\begin{array}{l}\text { Plano de } \\
\text { Controle de } \\
\text { Inundações }\end{array}$ & $\begin{array}{l}\text { Explanou sobre os trabalhos da câmara durante o ano anterior. } \\
\text { (Coordenador da Câmara Técnica de Drenagem e Controle de Inundações, } \\
\text { Eng. Marco Antônio Palermo) }\end{array}$ \\
\hline & $\begin{array}{l}\text { Recursos } \\
\text { financeiros }\end{array}$ & Discutiu-se os critérios para destinação dos recursos do FEHIDRO do ano. \\
\hline 08/06/1998 & $\begin{array}{l}\text { Agências de } \\
\text { bacias }\end{array}$ & $\begin{array}{l}\text { Comunicou a aprovação do projeto de lei que permite a instalação das } \\
\text { agências de bacia, sendo que as primeiras agências constituídas seriam as } \\
\text { do Piracicaba e do Alto Tietê. (Secretário Executivo do comitê, Eng. Hugo } \\
\text { Marques da Rosa) }\end{array}$ \\
\hline \multirow{3}{*}{ 08/06/1998 } & Poluição difusa & $\begin{array}{l}\text { Informou que o Plano Diretor de Esgotos abordaria o tratamento da água } \\
\text { pluvial em decorrência da poluição difusa. (Secretário Executivo do comitê, } \\
\text { Eng. Hugo Marques da Rosa) }\end{array}$ \\
\hline & Saneamento & $\begin{array}{l}\text { Inaugurou três novas estações de tratamento de esgotos que iriam contribuir } \\
\text { para a redução da carga poluente lançada nos rios. (Secretário Executivo do } \\
\text { comitê, Eng. Hugo Marques da Rosa) }\end{array}$ \\
\hline & $\begin{array}{l}\text { Plano de } \\
\text { Controle de } \\
\text { Inundações }\end{array}$ & $\begin{array}{l}\text { Apresentação do conteúdo e das etapas do plano, além da apresentação da } \\
\text { proposta de Termo de Referência da empresa Maubertec contratada pelo } \\
\text { DAEE. (Representante da Maubertec, Eng. André Luis Monteiro de Barros) } \\
\text { Explanação com recomendações para o Termo de Referência. } \\
\text { (Representante da Câmara Técnica de Drenagem e Controle de Inundações) }\end{array}$ \\
\hline 05/08/1998 & $\begin{array}{c}\text { Recursos } \\
\text { financeiros }\end{array}$ & $\begin{array}{l}\text { Constatou-se que ainda havia recursos disponíveis do FEHIDRO, desta } \\
\text { forma, entrou-se em pauta as diretrizes para utilização do mesmo. }\end{array}$ \\
\hline \multirow{3}{*}{ 05/08/1998 } & $\begin{array}{l}\text { Áreas de } \\
\text { Proteção de } \\
\text { Mananciais }\end{array}$ & $\begin{array}{l}\text { Apresentou o andamento do Plano Emergencial nas áreas de proteção de } \\
\text { mananciais. (Secretária Adjunta da Secretaria do Meio Ambiente, Sra. Vera } \\
\text { Dolores) }\end{array}$ \\
\hline & $\begin{array}{l}\text { Uso e ocupação } \\
\text { do solo }\end{array}$ & $\begin{array}{l}\text { Em decorrência do que foi discutido no Plano Emergencial, levantou-se a } \\
\text { questão das moradias irregulares e das intervenções necessárias em } \\
\text { moradias localizadas em cima ou ao lado dos córregos. }\end{array}$ \\
\hline & $\begin{array}{c}\text { Recursos } \\
\text { financeiros }\end{array}$ & Discussão sobre recursos financeiros do FEHIDRO. \\
\hline \multirow[t]{2}{*}{ 29/09/1998 } & $\begin{array}{l}\text { Plano } \\
\text { Emergencial de } \\
\text { Áreas de } \\
\text { Proteção de } \\
\text { Mananciais }\end{array}$ & $\begin{array}{l}\text { Homologou-se o Plano Emergencial aprovado pelos subcomitês. Descreveu } \\
\text { o processo de análise de áreas de intervenção no âmbito dos subcomitês } \\
\text { Tietê-Cabeceiras, Cotia-Guarapiranga e Billings-Tamanduaté e prestou } \\
\text { esclarecimentos. (Secretaria do Meio Ambiente e coordenadora do Grupo } \\
\text { de Trabalho, Vera Bononi) }\end{array}$ \\
\hline & $\begin{array}{c}\text { Recursos } \\
\text { financeiros }\end{array}$ & $\begin{array}{l}\text { Homologou-se as indicações de pedidos de financiamento com recursos } \\
\text { remanescentes do FEHIDRO dos subcomitês. }\end{array}$ \\
\hline \multirow[b]{2}{*}{ 02/12/1998 } & $\begin{array}{c}\text { Plano de } \\
\text { Macrodrenagem }\end{array}$ & $\begin{array}{l}\text { Explicou que o objetivo do plano era estudar todo os sistema de drenagem } \\
\text { da Bacia do Alto Tietê do ponto de vista de controle de enchentes. (Aloísio } \\
\text { Cagnoli) }\end{array}$ \\
\hline & Projeto Billings & $\begin{array}{l}\text { Explanou sobre o programa e esclareceu sobre a solicitação de recursos } \\
\text { para o projeto que seria destinado à implantação de um modelo de } \\
\text { monitoramento de qualidade de água na bacia Billings. (Coordenador do } \\
\text { Projeto Billings pela Secretaria de Recursos Hídricos, Eng. Lavradoro }\end{array}$ \\
\hline
\end{tabular}

Fonte: Sistema Integrado de Gerenciamento de Recursos Hídricos, compilado pela autora. 
Quadro 6 - Assuntos relevantes do ano 1999.

\begin{tabular}{|c|c|c|}
\hline Data & Tema & Detalhamento \\
\hline 29/03/1999 & $\begin{array}{l}\text { Posse dos } \\
\text { integrantes }\end{array}$ & $\begin{array}{l}\text { Reunião destinada a posse dos integrantes e eleição dos dirigentes para o } \\
\text { mandato 1999-2000. }\end{array}$ \\
\hline \multirow[t]{2}{*}{ 03/05/1999 } & $\begin{array}{l}\text { Plano } \\
\text { Emergencial de } \\
\text { Áreas de } \\
\text { Proteção de } \\
\text { Mananciais }\end{array}$ & $\begin{array}{l}\text { Apresentou o andamento do projeto, colocando seus objetivos e situação } \\
\text { em cada sub-bacia participante. (Representante da Secretaria do Meio } \\
\text { Ambiente e coordenadora do Grupo de Trabalho, Vera Bononi) }\end{array}$ \\
\hline & $\begin{array}{c}\text { Plano de } \\
\text { Macrodrenagem }\end{array}$ & $\begin{array}{l}\text { Explanou que o Plano Diretor de Macrodrenagem estava sendo } \\
\text { desenvolvido pelo Consórcio ENGER, contratado do DAEE, sendo ele } \\
\text { composto por cinto etapas. (Representante do Consórcio ENGER, Sr. } \\
\text { Aloísio Cagnoli) }\end{array}$ \\
\hline \multirow{3}{*}{ 15/06/1999 } & $\begin{array}{l}\text { Plano de } \\
\text { Recursos } \\
\text { Hídricos da bacia }\end{array}$ & $\begin{array}{l}\text { Apresentou o planejamento para construção do Plano de Trabalho dos } \\
\text { Recursos Hídricos e do Plano Diretor da Bacia Hidrográfica do Alto Tietê, } \\
\text { (Representante da Fundação Universidade de São Paulo, Prof. Mônica } \\
\text { Porto) }\end{array}$ \\
\hline & $\begin{array}{l}\text { Novos índices de } \\
\text { qualidade das } \\
\text { águas }\end{array}$ & $\begin{array}{l}\text { Apresentou a proposta de fazer a medição da qualidade da água com outros } \\
\text { índices: IVA (Índice de Proteção da Vida Aquática) e IAP (Índice da } \\
\text { Qualidade das Águas Brutas), além do IQA médio (Índice de Qualidade da } \\
\text { Água) que já era medido, devido ao uso desses rios. (Representante da } \\
\text { CETESB, Sra. Marta Lampareti) }\end{array}$ \\
\hline & $\begin{array}{l}\text { Leis específicas } \\
\text { de mananciais e } \\
\text { PDPAs }\end{array}$ & $\begin{array}{l}\text { Exibiu a situação de como estava as discussões sobre as leis específicas } \\
\text { para mananciais e dos trabalhos dos PDPA's para Guarapiranga, Billings, } \\
\text { Alto Tietê e Sistema Cantareira. (Representante da Secretaria do Meio } \\
\text { Ambiente, Sr. Eduardo Trani) }\end{array}$ \\
\hline \multirow{3}{*}{ 21/06/1999 } & $\begin{array}{l}\text { Plano de } \\
\text { Recursos } \\
\text { Hídricos da bacia }\end{array}$ & $\begin{array}{l}\text { Discorreu sobre o processo de elaboração do plano e comunicou que a } \\
\text { primeira etapa (diagnóstico da bacia) estava com previsão de término para } \\
\text { julho. (Representante da Fundação Universidade de São Paulo, Prof. } \\
\text { Mônica Porto) }\end{array}$ \\
\hline & $\begin{array}{l}\text { Novos índices de } \\
\text { qualidade das } \\
\text { águas }\end{array}$ & $\begin{array}{l}\text { Foi feita exposição dos índices e da metodologia utilizada, ressaltando que } \\
\text { a partir dos próximos relatórios da CETESB os novos índices já estariam } \\
\text { inclusos. (Representante da CETESB, Marta Lampareli e Nelson } \\
\text { Menegon) }\end{array}$ \\
\hline & $\begin{array}{l}\text { Lei Específica da } \\
\text { Guarapiranga }\end{array}$ & $\begin{array}{l}\text { Apresentou minuta da Lei Específica da bacia Guarapiranga. } \\
\text { (Representante da Secretaria do Meio Ambiente, Sr. Eduardo Trani) }\end{array}$ \\
\hline 23/08/1999 & $\begin{array}{l}\text { Plano Diretor de } \\
\text { Macrodrenagem }\end{array}$ & $\begin{array}{l}\text { Expôs sobre o andamento do plano, apresentando as primeiras etapas } \\
\text { concluídas do projeto. (Coordenador da Câmara Técnica de } \\
\text { Macrodrenagem, Eng. Marco Antônio Palermo) }\end{array}$ \\
\hline \multirow[t]{2}{*}{ 23/08/1999 } & $\begin{array}{l}\text { Plano } \\
\text { Emergencial de } \\
\text { Recuperação dos } \\
\text { Mananciais }\end{array}$ & $\begin{array}{l}\text { Apresentou o andamento do Plano Emergencial que cabe a SABESP } \\
\text { (saneamento). (Vice-presidente metropolitano da SABESP, Marcelo Sales) } \\
\text { Apresentou o andamento do Plano Emergencial que cabe a Secretaria de } \\
\text { Habitação, tratando do assunto CDHU. (Representante da Secretaria de } \\
\text { Habitação, Vera Bononi) }\end{array}$ \\
\hline & $\begin{array}{l}\text { Fiscalização em } \\
\text { áreas de } \\
\text { mananciais }\end{array}$ & $\begin{array}{l}\text { Dissertou que estava sendo elaborada proposta padrão para toda bacia do } \\
\text { Alto Tietê e que em um segundo momento seria discutido por sub-bacia. } \\
\text { (Diretor de fiscalização do Dusme - Secretaria Estadual do Meio Ambiente, } \\
\text { Sr. Dagoberto) }\end{array}$ \\
\hline
\end{tabular}


Quadro 6 - Assuntos relevantes do ano 1999.

\section{Continuação}

\begin{tabular}{|c|c|c|}
\hline Data & Tema & Detalhamento \\
\hline \multirow{4}{*}{$12 / 11 / 1999$} & $\begin{array}{l}\text { Córrego } \\
\text { Moendas }\end{array}$ & $\begin{array}{l}\text { Relatou as discussões sobre implantação de uma unidade educacional da } \\
\text { FEBEM em área do Parque Juqueri, no município de Franco da Rocha e } \\
\text { solicitou manifestação do comitê para possíveis impactos nos recursos } \\
\text { hídricos e em particular no córrego Moendas. (Secretário Executivo do } \\
\text { subcomitê Juqueri-Cantareira) } \\
\text { Solicitou que o Sr. Ivan Whately, diretor da CPOS, prestasse } \\
\text { esclarecimentos sobre a obra e encaminhou o assunto para as Câmaras } \\
\text { Técnicas de Qualidade e Quantidade. (Presidente do CBH-AT, Eng. Hugo } \\
\text { Marques da Rosa) }\end{array}$ \\
\hline & $\begin{array}{c}\text { Plano de } \\
\text { Recursos } \\
\text { Hídricos da bacia } \\
\end{array}$ & $\begin{array}{l}\text { Distribuiu minuta do Relatório de Situação dos Recursos Hídricos e } \\
\text { apresentou síntese do diagnóstico realizado. (Representante da Fundação } \\
\text { Universidade de São Paulo, Prof. Mônica Porto) }\end{array}$ \\
\hline & $\begin{array}{c}\text { Lei Específica da } \\
\text { Guarapiranga }\end{array}$ & $\begin{array}{l}\text { Elucidou que a minuta da Lei Específica da bacia Guarapiranga foi } \\
\text { distribuída para todos os subcomitês. (Representante da Secretaria do Meio } \\
\text { Ambiente, Sr. Eduardo Trani) }\end{array}$ \\
\hline & $\begin{array}{l}\text { Plano de } \\
\text { Contingência de } \\
\text { inundações }\end{array}$ & $\begin{array}{l}\text { Relatou estudos e ressaltou lista com pontos críticos em } 17 \text { sub-bacias, que } \\
\text { seriam objeto de intervenção. (Coordenador da Câmara Técnica de } \\
\text { Macrodrenagem, Eng. Marco Antônio Palermo) }\end{array}$ \\
\hline $25 / 11 / 1999$ & Deliberações & Reunião apenas com deliberações. \\
\hline $15 / 12 / 1999$ & Cancelada & união não atingiu o quórum. \\
\hline
\end{tabular}

Fonte: Sistema Integrado de Gerenciamento de Recursos Hídricos, compilado pela autora. 
Quadro 7 - Assuntos relevantes do ano 2000.

\begin{tabular}{|c|c|c|}
\hline Data & Tema & Detalhamento \\
\hline \multirow{3}{*}{$04 / 02 / 2000$} & $\begin{array}{l}\text { Agência da bacia } \\
\text { Alto Tietê }\end{array}$ & $\begin{array}{l}\text { Informou sobre o andamento do processo de constituição da agência. } \\
\text { (Secretário executivo do CBH-AT, Sr. João Gilberto Lotufo Conejo) }\end{array}$ \\
\hline & $\begin{array}{l}\text { Áreas de } \\
\text { mananciais }\end{array}$ & $\begin{array}{l}\text { Expôs a importância e urgência na regularização dos dispositivos } \\
\text { constitucionais sobre a regularização da compensação financeira aos } \\
\text { municípios em áreas de proteção de mananciais. (Prefeita do município } \\
\text { Ribeirão Pires, Sra. Maria Inês. }\end{array}$ \\
\hline & $\begin{array}{r}\text { Rect } \\
\text { finan }\end{array}$ & $\begin{array}{l}\text { Discutiu-se sobre a proposta das diretrizes para aplicação de recursos } \\
\text { financeiros do FEHIDRO para o ano. }\end{array}$ \\
\hline $02 / 05 / 2000$ & $\begin{array}{l}\text { Plano } \\
\text { Emergencial }\end{array}$ & $\begin{array}{l}\text { Apresentou detalhadamente a situação do plano e justificou atraso na } \\
\text { execução de obras devido à crise financeira ocorrida no ano } 1999 . \\
\text { (Representante da SABESP, Eng. Pedro Hallack) }\end{array}$ \\
\hline 06/06/2000 & $\begin{array}{l}\text { Recursos } \\
\text { financeiros }\end{array}$ & $\begin{array}{l}\text { Explanou sobre as mudanças no manual do FEHIDRO para destinação de } \\
\text { recursos para programas e projetos prioritários. (Presidente do CBH-AT, } \\
\text { Eng. Hugo Marques da Rosa) }\end{array}$ \\
\hline $18 / 07 / 2000$ & $\begin{array}{l}\text { Lei Específica de } \\
\text { mananciais }\end{array}$ & $\begin{array}{l}\text { Relatou o andamento dos trabalhos da Câmara Técnica sobre a minuta da } \\
\text { Lei Específica. (Representante do subcomitê Cotia-Guarapiranga, Rizpah } \\
\text { Besen) }\end{array}$ \\
\hline $20 / 08 / 2000$ & Abastecimento & $\begin{array}{l}\text { Expôs a situação dos reservatórios e as medidas que a empresa estava } \\
\text { tomando para regularizar o abastecimento diante da estiagem na RMSP. } \\
\text { (Representante da SABESP, Sr. Edson Airoli) }\end{array}$ \\
\hline $27 / 09 / 2000$ & Abastecimento & $\begin{array}{l}\text { Dissertou sobre as demandas e disponibilidades de água para cinco anos } \\
\text { subsequentes, falou sobre o programa de monitoramento de qualidade de } \\
\text { água realizado antes e depois do tratamento e esclareceu dúvidas dos } \\
\text { presentes. (Representante da SABESP, Sr. Edson Airoldi) }\end{array}$ \\
\hline $20 / 10 / 2000$ & Esgoto & $\begin{array}{l}\text { Apresentou as perspectivas da revisão do Plano Diretor de Esgotos da } \\
\text { RMSP. (Representante da SABESP, Sr. Edson Andrigueti) }\end{array}$ \\
\hline
\end{tabular}

Fonte: Sistema Integrado de Gerenciamento de Recursos Hídricos, compilado pela autora. 
Quadro 8 - Assuntos relevantes do ano 2001.

\begin{tabular}{|c|c|c|}
\hline Data & Tema & Detalhamento \\
\hline $20 / 02 / 2001$ & Reunião de posse & Reunião de posse dos novos membros do CBH-AT. \\
\hline \multirow{2}{*}{$27 / 04 / 2001$} & $\begin{array}{l}\text { Plano de } \\
\text { Recursos } \\
\text { Hídricos da bacia }\end{array}$ & $\begin{array}{l}\text { Expôs o estágio em que estava a elaboração do plano, objeto do relatório } \\
\text { "Subsídios para discussão do Plano de Bacia", enfatizou que as principais } \\
\text { diretrizes e linhas de ação já estavam propostas. (Representante da } \\
\text { Fundação Universidade de São Paulo, Prof. Mônica Porto) }\end{array}$ \\
\hline & Abastecimento & $\begin{array}{l}\text { Abordou a situação do abastecimento de água na RMSP, detalhando a } \\
\text { escassez de chuva, a produção média dos mananciais e as ações } \\
\text { desenvolvidas para reforçar o sistema de abastecimento. (Representante da } \\
\text { SABESP, Sr. Edson Airoldi) }\end{array}$ \\
\hline \multirow[b]{2}{*}{$30 / 08 / 2001$} & Abastecimento & $\begin{array}{l}\text { Expôs a temática sob dois aspectos: conjuntural (da seca) e estrutural (do } \\
\text { sistema de abastecimento), juntamente com as medidas tomadas pela } \\
\text { empresa. (Representante da SABESP, Sr. Edson Airoldi) }\end{array}$ \\
\hline & $\begin{array}{l}\text { Proteção de } \\
\text { mananciais }\end{array}$ & $\begin{array}{l}\text { Discorreu sobre um projeto de lei que altera a Lei } \mathrm{n}^{\circ} 1.172 / 76 \text {, de proteção } \\
\text { aos mananciais, permitindo que em vez dos ocupantes terem áreas de mata } \\
\text { ciliar junto ao terreno, possam compensar esta área dentro da mesma bacia, } \\
\text { podendo haver regularização do imóvel. (Secretário do Meio Ambiente, } \\
\text { Ricardo Tripoli) }\end{array}$ \\
\hline \multirow{3}{*}{$29 / 11 / 2001$} & $\begin{array}{l}\text { Proteção de } \\
\text { mananciais - } \\
\text { Guarapiranga }\end{array}$ & $\begin{array}{l}\text { Explanaram sobre a minuta da proposta de Lei Específica para a Área de } \\
\text { Proteção e Recuperação de Mananciais (APRM), elaborada pela Câmara } \\
\text { Técnica de Planejamento. (Presidente do subcomitê Cotia-Guarapiranga, } \\
\text { Lener do Nascimento Ribeiro, e membros da Câmara Técnica de } \\
\text { Planejamento) }\end{array}$ \\
\hline & $\begin{array}{l}\text { Sustentação } \\
\text { econômica dos } \\
\text { mananciais }\end{array}$ & $\begin{array}{l}\text { Dissertou sobre moção entregue ao Presidente da Assembleia Legislativa } \\
\text { cujo teor resumidamente recomenda: - a Regulamentação da Lei Estadual } \\
9146 / 95 \text {, que define a compensação financeira a quem contribui para a } \\
\text { proteção dos mananciais; - o encaminhamento à Assembléia Legislativa, } \\
\text { pelo Governo Estadual, de proposta de alteração da Lei 8510/93, que trata } \\
\text { do ICMS ecológico; - a aplicação pela SABESP, de parte dos recursos } \\
\text { auferidos com a tarifa na proteção aos mananciais; - o início imediato da } \\
\text { discussão pelo CBH-AT, das Leis Específicas da proteção aos mananciais; - } \\
\text { a implementação pelo CBH-AT, da Agênciada Bacia e a destinação dos } \\
\text { recursos para a proteção dos mananciais, pelos senhores Deputados } \\
\text { Estaduais, no orçamento estadual. }\end{array}$ \\
\hline & $\begin{array}{l}\text { Inundações - } \\
\text { Tietê }\end{array}$ & $\begin{array}{l}\text { Apresentou a segunda fase do rebaixamento da calha do rio Tietê. } \\
\text { (Representando do DAEE, Dr. Ricardo Borsari) }\end{array}$ \\
\hline $19 / 12 / 2001$ & Deliberações & Reunião apenas com deliberações. \\
\hline
\end{tabular}

Fonte: Sistema Integrado de Gerenciamento de Recursos Hídricos, compilado pela autora. 
ANEXO A - Síntese das Atas do Comitê de Bacia Hidrográfica Alto Tietê

Quadro 9 - Assuntos relevantes do ano 2002.

\begin{tabular}{|c|c|c|}
\hline Data & Tema & Detalhamento \\
\hline $04 / 04 / 2002$ & $\begin{array}{c}\text { Recursos } \\
\text { Financeiros }\end{array}$ & $\begin{array}{l}\text { Homologou-se os pedidos de financiamento com recursos do FEHIDRO de } \\
2001 \text {. }\end{array}$ \\
\hline \multirow[t]{3}{*}{$17 / 09 / 2002$} & $\begin{array}{c}\text { Inundações - } \\
\text { Tietê }\end{array}$ & $\begin{array}{l}\text { Levantou o questionamento sobre a Licença Ambiental de Instalação } \\
\text { referente ao rebaixamento da calha do rio Tietê, sem que tenham sido } \\
\text { ouvidas as prefeituras de Santana do Parnaíba e Pirapora do Bom Jesus e o } \\
\text { comitê. Advertiu sobre as medidas mitigadoras. (Prefeito de Santana do } \\
\text { Parnaíba, Sr. Silvio Peccioli) } \\
\text { Esclarece que o processo foi antecedido de audiências públicas e as } \\
\text { medidas mitigadoras são objeto de uma licitação em andamento pelo } \\
\text { DAEE. (Superintendente do DAEE, Dr. Ricardo Borsari) }\end{array}$ \\
\hline & $\begin{array}{l}\text { Proteção de } \\
\text { mananciais }\end{array}$ & $\begin{array}{l}\text { Informou o andamento dos PDPA's e das leis específicas e que recursos } \\
\text { foram destinados à EMPLASA para começar os trabalhos do PDPA da } \\
\text { bacia do rio Cotia. (Secretário do subcomitê Pinheiros-Pirapora) }\end{array}$ \\
\hline & $\begin{array}{l}\text { Proteção de } \\
\text { mananciais - } \\
\text { Guarapiranga }\end{array}$ & $\begin{array}{l}\text { Relatou que o projeto de Lei Específica para o Guarapiranga foi aprovado } \\
\text { pelo CONSEMA em 13/08 e que está pronto para ser encaminhado à } \\
\text { Assembleia. (Representante do subcomitê Billings-Tamanduateí, Sr. } \\
\text { Marcos Bandini) }\end{array}$ \\
\hline
\end{tabular}

Fonte: Sistema Integrado de Gerenciamento de Recursos Hídricos, compilado pela autora. 
Quadro 10 - Assuntos relevantes do ano 2003.

\begin{tabular}{|c|c|c|}
\hline Data & Tema & Detalhamento \\
\hline $03 / 04 / 2003$ & Inundações Tietê & $\begin{array}{l}\text { Observa que o rebaixamento da calha do rio Tietê foi planejado pensando } \\
\text { em diminuir as inundações na RMSP, porém devido ao levantamento dos } \\
\text { sedimentos do fundo do rio que estavam acumulados houveram problemas } \\
\text { no Médio Tietê, levando para a região poluentes. (Presidente do CBH-AT, } \\
\text { Sra. Marta Suplicy) }\end{array}$ \\
\hline \multirow{2}{*}{$03 / 04 / 2003$} & $\begin{array}{l}\text { Projeto de } \\
\text { Despoluição do } \\
\text { Tietê }\end{array}$ & $\begin{array}{l}\text { Fez colocação sobre o projeto afirmando que já haviam atingido } 61 \text { a } 62 \% \\
\text { de tratamento dos esgotos tratados na RMSP. (Dr. Antônio Marcília) }\end{array}$ \\
\hline & Poluição difusa & $\begin{array}{l}\text { Adicionou em sua fala que a poluição difusa não é apenas de } \\
\text { responsabilidade da sociedade civil, mas também das prefeituras. (Dr. } \\
\text { Antônio Marcília) }\end{array}$ \\
\hline $14 / 04 / 2003$ & $\begin{array}{l}\text { Recursos } \\
\text { financeiros }\end{array}$ & $\begin{array}{l}\text { Tratou dos critérios e as prioridades de aplicação de recursos do FEHIDRO } \\
\text { para o ano. }\end{array}$ \\
\hline $23 / 04 / 2003$ & $\begin{array}{l}\text { Recursos } \\
\text { financeiros }\end{array}$ & $\begin{array}{l}\text { Tratou dos critérios e as prioridades de aplicação de recursos do FEHIDRO } \\
\text { para o ano. }\end{array}$ \\
\hline \multirow[b]{2}{*}{$29 / 05 / 2003$} & $\begin{array}{l}\text { Recursos } \\
\text { financeiros }\end{array}$ & $\begin{array}{l}\text { Tratou dos critérios e as prioridades de aplicação de recursos do FEHIDRO } \\
\text { para o ano. }\end{array}$ \\
\hline & Saneamento & $\begin{array}{l}\text { Falou sobre a importância de um Projeto de Lei do Executivo Municipal de } \\
\text { São Paulo sobre regulação do saneamento, que incidiria sobre o Plano da } \\
\text { Bacia na hipótese de municipalização do serviço de saneamento. } \\
\text { (Representante da Prefeitura Municipal de São Paulo, Sra. Viviana de } \\
\text { Aquino Borges) }\end{array}$ \\
\hline \multirow[t]{2}{*}{ 03/06/2003 } & Saneamento & $\begin{array}{l}\text { Apresentou o Projeto de Lei } \mathrm{n}^{\circ} 219 \text { da prefeitura, que visa criar a política } \\
\text { municipal de saneamento e estabelecer o sistema de regulação do serviço de } \\
\text { saneamento no município. (Representante da Prefeitura Municipal de São } \\
\text { Paulo, Sra. Andréa de Oliveira Castro) }\end{array}$ \\
\hline & $\begin{array}{l}\text { Recursos } \\
\text { financeiros }\end{array}$ & $\begin{array}{l}\text { Homologou-se os pedidos de financiamento com recursos do FEHIDRO, de } \\
2003 \text {. }\end{array}$ \\
\hline
\end{tabular}

Fonte: Sistema Integrado de Gerenciamento de Recursos Hídricos, compilado pela autora. 
Quadro 11 - Assuntos relevantes do ano 2004.

\begin{tabular}{|c|c|c|}
\hline Data & Tema & Detalhamento \\
\hline $19 / 02 / 2004$ & $\begin{array}{l}\text { Proteção de } \\
\text { mananciais }\end{array}$ & $\begin{array}{l}\text { Comunicou a ideia do comitê de priorizar no ano } 2004 \text { os projetos que } \\
\text { tenham a ver com a elaboração das leis específicas. (Secretário Executivo } \\
\text { do CBH-AT, Sr. Ricardo Borsari) }\end{array}$ \\
\hline \multirow{2}{*}{$23 / 04 / 2004$} & Abastecimento & $\begin{array}{l}\text { Solicitou que o representante da SABESP apresentasse a situação do } \\
\text { abastecimento na RMSP diante da criticidade de escassez apresentada na } \\
\text { época, preocupado com os problemas de saúde da população. } \\
\text { (Representante do Instituto de Pesquisa em Ecologia Humana, Sr. Bonfilio) }\end{array}$ \\
\hline & $\begin{array}{l}\text { Proteção de } \\
\text { mananciais }\end{array}$ & $\begin{array}{l}\text { Solicitou audiência com os líderes partidários da ALESP para relatar } \\
\text { aprovação do comitê e do subcomitê, da Lei Específica Cotia- } \\
\text { Guarapiranga. (Presidente da Associação Comercial e Industrial do Embú - } \\
\text { ACISE, Sr. José Roberto Terassi) }\end{array}$ \\
\hline \multirow{3}{*}{$07 / 05 / 2004$} & Abastecimento & $\begin{array}{l}\text { Informou que havia sido solicitada outorga do sistema Cantareira. } \\
\text { (Executivo do CBH-AT, superintendente do DAEE, Eng. Ricardo Borsari) }\end{array}$ \\
\hline & $\begin{array}{l}\text { Proteção de } \\
\text { mananciais }\end{array}$ & $\begin{array}{l}\text { Questionou sobre a audiência com os líderes partidários da ALESP para } \\
\text { relatar aprovação do comitê e do subcomitê, da Lei Específica Cotia- } \\
\text { Guarapiranga. (Presidente da Associação Comercial e Industrial do Embú - } \\
\text { ACISE, Sr. José Roberto Terassi) }\end{array}$ \\
\hline & $\begin{array}{l}\text { Educação } \\
\text { ambiental }\end{array}$ & $\begin{array}{l}\text { Comunicou a inauguração de um Núcleo Municipal de Educação } \\
\text { Ambiental dentro de uma ilha fluvial no rio Tietê e área entregue como } \\
\text { compensação ambiental que irá funcionar como Núcleo de Educação } \\
\text { Ambiental para formação de professores, na cidade de Mogi das Cruzes. } \\
\text { (Vice-presidente do subcomitê Alto Tietê-Cabeceiras, Sr. Arraes) }\end{array}$ \\
\hline $29 / 06 / 2004$ & Abastecimento & $\begin{array}{l}\text { Apresentou as estratégias para abastecimento de água na RMSP e o que } \\
\text { está sendo feito na bacia do PCJ, da qual foram retirados } 31 \mathrm{~m}^{3} / \mathrm{s} \text { para } \\
\text { abastecer a RMSP e mostrou um panorama geral da atuação da empresa no } \\
\text { Estado. (Representante da SABESP, Sr. Francisco José de Toledo Piza) } \\
\text { Dissertou sobre o abastecimento em São Paulo. (Superintendente de } \\
\text { Produção de Águas da SABESP, Sr. Hélio Luis Castro) } \\
\text { Apresentou tópicos do Plano Diretor de Abastecimento de Água da RMSP. } \\
\text { (Superintendente de Planejamento Técnicos Integrado da SABESP, Sr. } \\
\text { Edson) }\end{array}$ \\
\hline \multirow[b]{2}{*}{ 26/07/2004 } & Abastecimento & $\begin{array}{l}\text { Relatou como chegaram a minuta de deliberação sobre a renovação de } \\
\text { outorga na Cantareira. (Representante do DAEE, Sr. Márcio) }\end{array}$ \\
\hline & $\begin{array}{c}\text { Legislação - } \\
\text { Código Florestal }\end{array}$ & $\begin{array}{l}\text { Notificou sobre aprovação do Congresso de um projeto de lei alterando o } \\
\text { dispositivo do Código Florestal e praticamente cancelando a } \\
\text { obrigatoriedade de cumprimento de um dispositivo do código em áreas } \\
\text { urbanas, a preservação das áreas, matas ciliares, da faixa marginal aos rios } \\
\text { em áreas urbanas. Mostrou sua preocupação com os recursos hídricos } \\
\text { superficiais e subterrâneos. (Sr. Rubens) }\end{array}$ \\
\hline $14 / 12 / 2004$ & Deliberações & Reunião com deliberações. \\
\hline
\end{tabular}

Fonte: Sistema Integrado de Gerenciamento de Recursos Hídricos, compilado pela autora. 
ANEXO A - Síntese das Atas do Comitê de Bacia Hidrográfica Alto Tietê

Quadro 12 - Assuntos relevantes do ano 2005.

\begin{tabular}{|c|c|c|}
\hline Data & Tema & Detalhamento \\
\hline $15 / 03 / 2005$ & Deliberações & Reunião com deliberações. \\
\hline $30 / 06 / 2005$ & Votação & Reunião apenas para votação do comitê. \\
\hline 06/07/2005 & Plano da Bacia & $\begin{array}{l}\text { Coloca que diante dos avanços de investimento nos projetos, deve-se dar } \\
\text { prioridade a atualização do Plano de Bacia. (Representante da } \\
\text { Coordenadoria de Recursos Hídricos, Eng. Márcio Correia Ribeiro) }\end{array}$ \\
\hline $27 / 07 / 2005$ & $\begin{array}{c}\text { Uso e ocupação } \\
\text { do solo }\end{array}$ & $\begin{array}{l}\text { Apresentação do projeto "Mapas de uso e ocupação do solo da RMSP". } \\
\text { (Coordenadora do projeto e representante da EMPLASA, Dra. Francisca } \\
\text { Luisa) }\end{array}$ \\
\hline \multirow{4}{*}{$25 / 10 / 2005$} & $\begin{array}{l}\text { Programa } \\
\text { mananciais }\end{array}$ & $\begin{array}{l}\text { Informou que estão aguardando aprovação da COFIEX para alocação de } \\
\text { recursos. (Representante da Prefeitura Municipal de São Bernardo do } \\
\text { Campo) }\end{array}$ \\
\hline & Saneamento & $\begin{array}{l}\text { Em sua exposição colocou que diante dos problemas com lançamentos de } \\
\text { esgotos o Projeto Tietê estaria deixando os rios principais nas mesmas } \\
\text { condições que se encontram. (Presidente da Agência da Bacia do Alto } \\
\text { Tietê, Dr. Júlio Cerqueira César) } \\
\text { Comunicou que o Projeto Tietê estava em andamento na segunda etapa e } \\
\text { que já estavam providenciando estudos para dar continuidade ao projeto, } \\
\text { que seria a terceira fase. (Representante da SABESP, Sr. Edson) }\end{array}$ \\
\hline & Despoluição & $\begin{array}{l}\text { Adicionou que estavam dentro dos estudos da Agência da Bacia o } \\
\text { aprofundamento de estudo sobre a qualidade das águas superficiais } \\
\text { introduzindo enfoque ambiental e de saneamento básico. (Presidente da } \\
\text { Agência da Bacia do Alto Tietê, Dr. Júlio Cerqueira César) }\end{array}$ \\
\hline & $\begin{array}{c}\text { Legislação - Lei } \\
11.106\end{array}$ & $\begin{array}{l}\text { Manifestou preocupação e solicitou um balanço qualitativo e quantitativo } \\
\text { da aplicação da Lei n }{ }^{\circ} 11.106 \text { - Lei Trípoli. Afirmou que obtiveram apenas } \\
20 \text { casos de aplicação e que nenhum deles demandou compensação } \\
\text { ambiental "decente" para a bacia. (Representante da Prefeitura Municipal } \\
\text { de São Paulo, Sra. Violeta) }\end{array}$ \\
\hline
\end{tabular}

Fonte: Sistema Integrado de Gerenciamento de Recursos Hídricos, compilado pela autora. 
ANEXO A - Síntese das Atas do Comitê de Bacia Hidrográfica Alto Tietê

Quadro 13 - Assuntos relevantes do ano 2006.

\begin{tabular}{|c|c|c|}
\hline Data & Tema & Detalhamento \\
\hline $13 / 04 / 2006$ & Agência da Bacia & $\begin{array}{l}\text { Apresentou o Plano de Trabalho da Agência da Bacia. (Presidente da } \\
\text { Agência da Bacia do Alto Tietê, Dr. Júlio Cerqueira César) }\end{array}$ \\
\hline $29 / 06 / 2006$ & Rios urbanos & $\begin{array}{l}\text { Aproveitou para contar sobre o IV Fórum Mundial de Águas e levantar a } \\
\text { questão dos rios urbanos, as enchentes, os riscos e a qualidade das águas } \\
\text { nas metrópoles. } \\
\text { Abordou ainda a visão que a população tem dos rios devido as suas } \\
\text { condições de degradação (Representante da Secretaria do Verde e do Meio } \\
\text { Ambiente do município de São Paulo, Sr. Gilmar Altamirano) }\end{array}$ \\
\hline $05 / 10 / 2006$ & Mananciais & $\begin{array}{l}\text { Fez crítica sobre o posicionamento do comitê diante da questão dos } \\
\text { impactos de obras do Rodoanel nas áreas de mananciais. O comitê rejeitou } \\
\text { o EIA-RIMA e quase sete meses depois ainda não havia sido resolvida a } \\
\text { questão. O CONSEMA aprovou a licença prévia do empreendimento, } \\
\text { porém a licença de instalação ainda não havia sido expedida, de modo que } \\
\text { o comitê poderia fazer intervenção. Desta forma, propôs o encaminhamento } \\
\text { do assunto a CT de planejamento. (Sr. Bonfílio) }\end{array}$ \\
\hline \multirow{2}{*}{$19 / 12 / 2006$} & Falta de quórum & $\begin{array}{l}\text { Reclamou devido à falta de comprometimento dos membros do comitê, } \\
\text { havendo muitas faltas e não conseguindo prosseguir com a reunião. (Vice- } \\
\text { presidente do subcomitê Tietê-Cabeceiras, Sr. José Arraes) }\end{array}$ \\
\hline & $\begin{array}{l}\text { Proteção de } \\
\text { mananciais }\end{array}$ & $\begin{array}{l}\text { Fez esclarecimentos sobre a regulamentação da Lei Específica do } \\
\text { manancial Guarapiranga (Representante da Secretaria do Meio Ambiente, } \\
\text { Dra. Lúcia de Sena) }\end{array}$ \\
\hline
\end{tabular}

Fonte: Sistema Integrado de Gerenciamento de Recursos Hídricos, compilado pela autora. 
Quadro 14 - Assuntos relevantes do ano 2007.

\begin{tabular}{|c|c|c|}
\hline Data & Tema & Detalhamento \\
\hline $19 / 03 / 2007$ & $\begin{array}{l}\text { Proteção de } \\
\text { mananciais }\end{array}$ & $\begin{array}{l}\text { Informou que foi decidido pelo comitê enviar moção ao governador para } \\
\text { que antes da edição final da Lei Específica da Guarapiranga, este } \\
\text { considerasse no mínimo um debate. (Secretário executivo do CBH-AT, Sr. } \\
\text { Márcio Corrêa) }\end{array}$ \\
\hline \multirow[b]{2}{*}{$12 / 04 / 2007$} & $\begin{array}{l}\text { Recursos } \\
\text { financeiros }\end{array}$ & Tratou sobre aplicação de recursos do FEHIDRO. \\
\hline & $\begin{array}{l}\text { Proteção de } \\
\text { mananciais }\end{array}$ & $\begin{array}{l}\text { Colocou sua opinião de que o comitê devia priorizar as questões das leis } \\
\text { específicas. (Coordenadora de recursos hídricos da Secretaria Estadual de } \\
\text { Meio Ambiente, Sra. Rosa Maria Mancini) } \\
\text { Disse que há um Grupo de Trabalho elaborando o trabalho da Lei } \\
\text { Específica na Billings, e passou o cronograma do grupo para que o comitê } \\
\text { pudesse acompanhar as discussões, caso houvesse interesse. (Representante } \\
\text { da Secretaria do Meio Ambiente, Sra. Lina Maria) }\end{array}$ \\
\hline $06 / 09 / 2007$ & - & Não houve temas relevantes para a pesquisa. \\
\hline $\begin{array}{l}31 / 10 / 2007 \\
\text { minuta }\end{array}$ & - & $\begin{array}{l}\text { Foram indicados novos membros e entidades para compor Câmaras } \\
\text { Técnicas, Grupos de Trabalho e o CBH-AT. }\end{array}$ \\
\hline \multirow[t]{2}{*}{$10 / 12 / 2007$} & $\begin{array}{l}\text { Recursos } \\
\text { financeiros }\end{array}$ & $\begin{array}{l}\text { Informou que haveria corte nos recursos do ano e o comitê solicitou que se } \\
\text { fizesse absolutamente nada neste ano, pois havia a necessidade de definir } \\
\text { nova fórmula para escolha de projetos. (Presidente do CBH-AT, Sr. Clóvis } \\
\text { Volpi) }\end{array}$ \\
\hline & $\begin{array}{l}\text { Proteção de } \\
\text { mananciais }\end{array}$ & $\begin{array}{l}\text { Apresentou minuta da Lei Específica da APRM do reservatório Billings. } \\
\text { (Coordenadora do Grupo de Trabalho, Sra. Silmara Martins) }\end{array}$ \\
\hline
\end{tabular}

Fonte: Sistema Integrado de Gerenciamento de Recursos Hídricos, compilado pela autora. 
Quadro 15 - Assuntos relevantes do ano 2008.

\begin{tabular}{|c|c|c|}
\hline Data & Tema & Detalhamento \\
\hline \multirow{2}{*}{$28 / 01 / 2008$} & $\begin{array}{c}\text { Plano de } \\
\text { Recursos } \\
\text { Hídricos da bacia }\end{array}$ & $\begin{array}{l}\text { Apresentou o diagnóstico analítico da Bacia do Alto Tietê. (Representante } \\
\text { da Fundação Universidade de São Paulo, Sr. Luiz Fernando) }\end{array}$ \\
\hline & $\begin{array}{l}\text { Proteção de } \\
\text { mananciais }\end{array}$ & $\begin{array}{l}\text { Levantou a necessidade de inclusão de instrumentos de gestão, como, por } \\
\text { exemplo, a lei específica do Guarapiranga e o PDPA. (Representante da } \\
\text { Secretaria do Meio Ambiente, Márcia Nascimento) }\end{array}$ \\
\hline \multirow{4}{*}{$10 / 03 / 2008$} & $\begin{array}{c}\text { Recursos } \\
\text { financeiros }\end{array}$ & $\begin{array}{l}\text { Discorrem sobre sugestões na inscrição de projetos e nos critérios de } \\
\text { escolha de empreendimentos para receber recursos do FEHIDRO. }\end{array}$ \\
\hline & $\begin{array}{l}\text { Classificação e } \\
\text { enquadramento } \\
\text { dos corpos } \\
\text { hídricos }\end{array}$ & $\begin{array}{l}\text { Expôs que o CBH-AT não conseguiu avançar nos tópicos: classificação dos } \\
\text { cursos d'água e enquadramento hídricos, nos últimos dez anos. } \\
\text { (Representante da sociedade civil, Sr. Bonfílio Alvez) }\end{array}$ \\
\hline & $\begin{array}{l}\text { Águas } \\
\text { subterrâneas }\end{array}$ & $\begin{array}{l}\text { Relatou: "Identificamos que o Estado através do DAEE e Sabesp enviam } \\
\text { pessoas apenas para cumprir uma agenda, de maneira que essas Câmaras } \\
\text { Técnicas acabam sendo fórum deliberativo em seu próprio âmbito, o que } \\
\text { foi discutido fica apenas ali e não se transforma em políticas públicas e } \\
\text { enquanto isso ocorrer não adianta, é só fazer reuniões e ocupar nosso } \\
\text { tempo, então estamos centrando todo o esforço da Câmara Técnica em } \\
\text { transformar esse importante tema, as águas subterrâneas, e chamar a } \\
\text { atenção criando mecanismos junto ao DAEE e Sabesp e ao governo do } \\
\text { Estado em políticas públicas, ou seja para que haja de fato uma } \\
\text { preocupação do Estado no uso das águas subterrâneas (...)". (Coordenador } \\
\text { da Câmara Técnica Águas Subterrâneas, Sr. Pedro Camelo) }\end{array}$ \\
\hline & $\begin{array}{c}\text { Programa } \\
\text { Córrego Limpo }\end{array}$ & $\begin{array}{l}\text { Informou a entrega do relatório do projeto, onde destaca-se a despoluição } \\
\text { de quarenta e dois córregos.(Representante da Prefeitura Municipal de São } \\
\text { Paulo, Sr. Gilmar Altamirano) }\end{array}$ \\
\hline \multirow[b]{2}{*}{$31 / 03 / 2008$} & Posse & Posse de novos membros no Conselho Curador da FABHAT. \\
\hline & $\begin{array}{c}\text { Recursos } \\
\text { financeiros }\end{array}$ & $\begin{array}{l}\text { Deliberou sobre projetos aprovados para execução com recursos do } \\
\text { FEHIDRO. }\end{array}$ \\
\hline $26 / 05 / 2008$ & Posse & $\begin{array}{l}\text { Posse aos novos membros da sociedade civil no Conselho Curador da } \\
\text { FABHAT. }\end{array}$ \\
\hline \multirow{3}{*}{$07 / 10 / 2008$} & $\begin{array}{l}\text { Enquadramento } \\
\text { dos corpos } \\
\text { hídricos }\end{array}$ & $\begin{array}{l}\text { Informou que a Câmara Técnica enviou proposta para que o Plano da Bacia } \\
\text { pudesse considerar as questões de reenquadramento dos corpos d'água. } \\
\text { (Relator da Câmara Técnica de Saneamento Ambiental, Sr. Edson } \\
\text { Andriguetti) }\end{array}$ \\
\hline & $\begin{array}{c}\text { Programa } \\
\text { Córrego Limpo }\end{array}$ & $\begin{array}{l}\text { Dissertou sobre a necessidade de integrar o programa ao Plano da Bacia } \\
\text { (Relator da Câmara Técnica de Saneamento Ambiental, Sr. Edson } \\
\text { Andriguetti) }\end{array}$ \\
\hline & Plano da Bacia & $\begin{array}{l}\text { Apresentou as diretrizes do plano de ações para o CBH-AT. (Representante } \\
\text { da Fundação Universidade de São Paulo, Prof. Mônica Porto) }\end{array}$ \\
\hline $05 / 11 / 2008$ & Saneamento & $\begin{array}{l}\text { "(...) informou que estava em discussão propostas: para valorizar o uso } \\
\text { racional da água da bacia; do lançamento de cargas poluidoras, sendo que } \\
\text { em função da melhoria da eficiência no tratamento, maior seria a dedução } \\
\text { do valor." (Coordenador do Grupo de Trabalho Cobrança, Jorge Rocco) }\end{array}$ \\
\hline $16 / 12 / 2008$ & $\begin{array}{l}\text { Educação } \\
\text { ambiental }\end{array}$ & $\begin{array}{l}\text { Foi discutido se os projetos de comunicação e educação ambiental seriam } \\
\text { mantidos como prioritários, havendo muitas críticas sobre o tema. }\end{array}$ \\
\hline
\end{tabular}

Fonte: Sistema Integrado de Gerenciamento de Recursos Hídricos, compilado pela autora. 
Quadro 16 - Assuntos relevantes do ano 2009.

\begin{tabular}{|c|c|c|}
\hline Data & Tema & Detalhamento \\
\hline \multirow{3}{*}{$12 / 01 / 2009$} & Plano da Bacia & $\begin{array}{l}\text { Comunicou que havia sido encaminhado ao CRH no final do ano de } 2008 \text { a } \\
\text { revisão do Plano da Bacia exercício de 2008-2011 e o Plano de Ação de } \\
\text { Investimentos, o Relatório de Situação de Recursos Hídricos } 2008 \text { - ano } \\
\text { base } 2007 \text { e o Cronograma de Cobrança pelo Uso da Água. (Secretária } \\
\text { executiva adjunta do CBH-AT, Sra. Maria Emília Botelho) }\end{array}$ \\
\hline & $\begin{array}{l}\text { Recursos } \\
\text { financeiros }\end{array}$ & $\begin{array}{l}\text { Discutiu sobre os critérios de pontuação e hierarquização dos } \\
\text { empreendimentos a serem financiados com recursos do FEHIDRO. }\end{array}$ \\
\hline & $\begin{array}{l}\text { Educação } \\
\text { ambiental }\end{array}$ & $\begin{array}{l}\text { Diversos membros opinaram sobre a capacitação em educação ambiental } \\
\text { para formação de projetos e sobre a criação de Plano de Ação de Educação } \\
\text { Ambiental. }\end{array}$ \\
\hline \multirow[b]{2}{*}{$09 / 02 / 2009$} & $\begin{array}{l}\text { Recursos } \\
\text { financeiros }\end{array}$ & Esclarecimento de questões levantadas a partir da última reunião. \\
\hline & $\begin{array}{l}\text { Saneamento e } \\
\text { drenagem }\end{array}$ & $\begin{array}{l}\text { Informou que a Câmara Técnica de Drenagem Aproveitamento Hidráulica e } \\
\text { Regras Operativas, verificando a problemática das interferências entre os } \\
\text { sistemas de coleta e tratamento de esgotos sanitários e o sistema de } \\
\text { drenagem das águas pluviais e fluviais, e a elaboração da revisão e } \\
\text { atualização do plano diretor de esgotos da região metropolitana de São } \\
\text { Paulo, em andamento na Sabesp, solicitou a inclusão de analise para a } \\
\text { utilização do conceito de sistemas mistos, ou unitários, para a região } \\
\text { metropolitana de São Paulo. (Secretária Executiva Adjunta, Sra. Maria } \\
\text { Emília Botelho) }\end{array}$ \\
\hline $27 / 04 / 2009$ & Plano de Esgoto & $\begin{array}{l}\text { Apresentou a revisão e atualização do Plano Diretor de Esgotos da } \\
\text { SABESP para a RMSP. (Representante da SABESP, Sr. Edson Andrighetti) }\end{array}$ \\
\hline $29 / 06 / 2009$ & Deliberações & Reunião com deliberações. \\
\hline $07 / 10 / 2009$ & $\begin{array}{l}\text { Recursos } \\
\text { financeiros }\end{array}$ & $\begin{array}{l}\text { Discussão sobre a hierarquização dos projetos a serem indicados para } \\
\text { recebimento de recursos do FEHIDRO. }\end{array}$ \\
\hline $18 / 11 / 2009$ & $\begin{array}{l}\text { Projetos } \\
\text { aprovados pelo } \\
\text { FEHIDRO }\end{array}$ & $\begin{array}{l}\text { Colocou-se em pauta os empreendimentos em execução com atraso de mais } \\
\text { de dois anos e os que não haviam prestado contas da última parcela } \\
\text { recebida. }\end{array}$ \\
\hline $18 / 12 / 2009$ & Deliberações & Reunião com deliberações. \\
\hline
\end{tabular}

Fonte: Sistema Integrado de Gerenciamento de Recursos Hídricos, compilado pela autora. 
Quadro 17 - Assuntos relevantes do ano 2010.

\begin{tabular}{|c|c|c|}
\hline Data & Tema & Detalhamento \\
\hline $29 / 03 / 2010$ & $\begin{array}{l}\text { Recursos } \\
\text { financeiros }\end{array}$ & $\begin{array}{l}\text { Foi proposto conceder maior prazo para as entidades que foram } \\
\text { consideradas aptas a captar recursos, com o intuito de permitir que houve } \\
\text { complementação na documentação. }\end{array}$ \\
\hline $26 / 05 / 2010$ & $\begin{array}{l}\text { Recursos } \\
\text { financeiros }\end{array}$ & $\begin{array}{l}\text { Discussão sobre hierarquização e indicação de empreendimentos para } \\
\text { financiamento com recursos do FEHIDRO. }\end{array}$ \\
\hline $18 / 11 / 2010$ & Rodoanel & $\begin{array}{l}\text { Solicitou esclarecimentos quanto à implantação e responsabilidades da } \\
\text { obra, pois o dique que estava sendo construído no Jardim Romano Não } \\
\text { estava de acordo com o projeto, não havendo recuo em relação ao rio Tietê, } \\
\text { redução na quantidade de casas removidas do local e os entulhos se } \\
\text { encontravam às margens do rio. (Sr. Edson José de Barros, Prefeitura de } \\
\text { Guarulhos) } \\
\text { Foi decidido pelo CBH-AT realizar reunião extraordinária da Câmara } \\
\text { Técnica e opinou sobre interditar imediatamente a obra por não } \\
\text { cumprimento das avaliações técnicas realizadas e pela inoportunidade da } \\
\text { construção. }\end{array}$ \\
\hline \multirow[t]{3}{*}{$16 / 12 / 2010$} & $\begin{array}{l}\text { Qualidade de } \\
\text { água }\end{array}$ & $\begin{array}{l}\text { Encaminhou solicitação da prefeitura de Cajamar para a continuidade do } \\
\text { projeto monitoramento da quantidade e qualidade das águas do rio Juquery. } \\
\text { (Secretário executivo do subcomitê Juquery-Cantareira, Sr. Osvaldo Vieira) } \\
\text { Disse que o projeto foi aprovado no subcomitê, beneficiando cinco } \\
\text { municípios da sub-bacia Juquery-Cantareira, perfazendo nove pontos de } \\
\text { monitoramento da qualidade da água em tempo real, com a intenção de } \\
\text { também subsidiar os estudos para enquadramento dos corpos hídricos na } \\
\text { bacia segundo previsto no Plano de Bacia do Alto Tietê (Representante da } \\
\text { Prefeitura de Cajamar, Sr. Luiz Vasconcelos) }\end{array}$ \\
\hline & $\begin{array}{l}\text { Relatório } \\
\text { Situação da BH- } \\
\text { AT }\end{array}$ & Apresentação e aprovação do Relatório de Situação com base no ano 2008. \\
\hline & Rodoanel & Houveram manifestações e explicações sobre as obras do Rodoanel. \\
\hline
\end{tabular}

Fonte: Sistema Integrado de Gerenciamento de Recursos Hídricos, compilado pela autora. 
ANEXO A - Síntese das Atas do Comitê de Bacia Hidrográfica Alto Tietê

Quadro 18 - Assuntos relevantes do ano 2011.

\begin{tabular}{|c|c|l|}
\hline Data & Tema & \multicolumn{1}{c|}{ Detalhamento } \\
\hline $16 / 02 / 2011$ & Deliberações & Reunião com deliberações. \\
\hline $31 / 03 / 2011$ & Posse & Reunião de posse da nova gestão do CBH-AT. \\
20/04/2011 & Articulação & $\begin{array}{l}\text { Reunião composta por temas relativos a articulação do comitê com a } \\
\text { sociedade civil e entre os membros do comitê e subcomitês. }\end{array}$ \\
\hline 30/06/2011 & $\begin{array}{c}\text { Sistema produtor } \\
\text { São Lourenço }\end{array}$ & $\begin{array}{l}\text { Fez esclarecimentos sobre o empreendimento, pois o mesmo envolvia a } \\
\text { transposição de bacia do Vale do Ribeira até o Alto Tietê. (Representante } \\
\text { da SABESP, Sr. Silvio Siqueira) }\end{array}$ \\
\hline $06 / 10 / 2011$ & $\begin{array}{c}\text { Recursos } \\
\text { financeiros }\end{array}$ & Deliberações sobre projetos e recursos financeiros do FEHIDRO. \\
\hline
\end{tabular}

Fonte: Sistema Integrado de Gerenciamento de Recursos Hídricos, compilado pela autora. 
ANEXO A - Síntese das Atas do Comitê de Bacia Hidrográfica Alto Tietê

Quadro 19 - Assuntos relevantes do ano 2012.

\begin{tabular}{|c|c|l|}
\hline Data & Tema & \multicolumn{1}{c|}{ Detalhamento } \\
\hline 12/03/2012 & $\begin{array}{l}\text { Proteção de } \\
\text { mananciais }\end{array}$ & $\begin{array}{l}\text { CBH-AT aprovou moção à Deputada Célia Leão da Comissão de Meio } \\
\text { Ambiente e Desenvolvimento Sustentável da Assembleia Legislativa de } \\
\text { São Paulo (ALESP) para dar celeridade na aprovação do projeto de lei } \\
\text { específica Juquery-Cantareira. }\end{array}$ \\
\hline
\end{tabular}

Fonte: Sistema Integrado de Gerenciamento de Recursos Hídricos, compilado pela autora. 
Quadro 20 - Assuntos relevantes do ano 2013.

\begin{tabular}{|c|c|c|}
\hline Data & Tema & Detalhamento \\
\hline $02 / 05 / 2013$ & $\begin{array}{l}\text { Proteção de } \\
\text { mananciais }\end{array}$ & $\begin{array}{l}\text { Esclareceram que não houve evolução para aprovação do projeto de lei } \\
\text { específica Juquery-Cantareira. Desta forma, o presidente do comitê se } \\
\text { comprometeu em marcar reunião com os líderes da ALESP para tratar } \\
\text { sobre o assunto. }\end{array}$ \\
\hline $04 / 06 / 2013$ & $\begin{array}{c}\text { Estatuto do } \\
\text { CBH-AT }\end{array}$ & Reunião para definição e aprovação de reformas no estatuto. \\
\hline $13 / 06 / 2013$ & $\begin{array}{l}\text { Proteção de } \\
\text { mananciais }\end{array}$ & $\begin{array}{l}\text { Informou que o texto base elaborado pelo subcomitê Juquery-Cantareira } \\
\text { que dispunha sobre a APRM Alto Juquery havia sido enviado em } 2010 \text { para } \\
\text { a ALESP e estava em análise desde então. }\end{array}$ \\
\hline $23 / 08 / 2013$ & Deliberações & Reunião com deliberações. \\
\hline $30 / 08 / 2013$ & Eleição e Posse & Eleição e posse para gestão 2013 a 2015. \\
\hline \multirow[t]{2}{*}{$01 / 10 / 2013$} & Grupos técnicos & $\begin{array}{l}\text { Ocorreu informes sobre o andamento e as prioridades dos trabalhos } \\
\text { realizados pelos Grupos Técnicos. O Grupo Técnico Planejamento estava } \\
\text { dedicando sua atenção para a revisão do Termo de Referência do Plano da } \\
\text { Bacia e acompanhamento do PDPA das áreas de mananciais da região } \\
\text { metropolitana. }\end{array}$ \\
\hline & Deliberação & Reunião com deliberações. \\
\hline $07 / 11 / 2013$ & Abastecimento & $\begin{array}{l}\text { Apresentou os oito sistemas produtores de água e as Estações de } \\
\text { Tratamento de Água (ETA's) da RMSP. (Diretor Metropolitano da } \\
\text { SABESP, Eng. Paulo Massato) }\end{array}$ \\
\hline $18 / 12 / 2013$ & Deliberação & Reunião com deliberações. \\
\hline
\end{tabular}

Fonte: Sistema Integrado de Gerenciamento de Recursos Hídricos, compilado pela autora. 
Quadro 21 - Assuntos relevantes do ano 2014.

\begin{tabular}{|c|c|c|}
\hline Data & Tema & Detalhamento \\
\hline $05 / 02 / 2014$ & Escassez hídrica & $\begin{array}{l}\text { Encaminhou moção que recomenda ações aos poderes públicos e à } \\
\text { sociedade civil em razão da atual escassez hídrica extrema. }\end{array}$ \\
\hline $26 / 05 / 2014$ & Abastecimento & $\begin{array}{l}\text { Apresentou as ações que estavam sendo desenvolvidas a curto e médio } \\
\text { prazo com o intuito de minimizar a escassez hídrica. (Eng. Marco Antônio) }\end{array}$ \\
\hline \multirow{8}{*}{$28 / 07 / 2014$} & Mananciais & $\begin{array}{l}\text { Apresentou o Sistema de Gestão de Informações das áreas de mananciais. } \\
\text { (Coordenador do Programa Mananciais, Sr. Amauri Pollachi) }\end{array}$ \\
\hline & Escassez hídrica & $\begin{array}{l}\text { Apresentou o Saneamento Básico do Município de Mauá (SAMA). } \\
\text { (Representante do SAMA, Sra. Teresa Carniel) }\end{array}$ \\
\hline & Escassez hídrica & $\begin{array}{l}\text { Apresentou o Serviço Municipal de Águas e Esgotos (SEMAE) de Mogi } \\
\text { das Cruzes. (Representante do SEMAE, Sra. Milena) }\end{array}$ \\
\hline & Escassez hídrica & $\begin{array}{l}\text { Apresentou o Serviço Municipal de Saneamento Ambiental de Santo André } \\
\text { (SEMASA). (Representante do SEMASA, Sr. Nilton Joseph) }\end{array}$ \\
\hline & Escassez hídrica & $\begin{array}{l}\text { Apresentou o Departamento de Água e Esgoto (DAE) de São Caetano do } \\
\text { Sul. (Representante do DAE, Sr. Horácio Pires) }\end{array}$ \\
\hline & Escassez hídrica & $\begin{array}{l}\text { Apresentou o Serviço Autônomo de Água e Esgoto (SAEE) de Guarulhos. } \\
\text { (Representante do DAE, Sr. Marco Aurélio Cardoso) }\end{array}$ \\
\hline & Escassez hídrica & $\begin{array}{l}\text { Apresentou ações que o DAEE fez juntamente com a SABESP para } \\
\text { economizar a água do Sistema Produtor Alto Tietê. (Representante do } \\
\text { DAEE, Sra. Seica Ono) }\end{array}$ \\
\hline & $\begin{array}{l}\text { Qualidade da } \\
\text { água }\end{array}$ & $\begin{array}{l}\text { Dissertou sobre o monitoramento da qualidade das águas que a CETESB } \\
\text { estava realizando: rede básica, monitoramento automático, balneabilidade } \\
\text { de rios e reservatórios e rede de sedimento. (Representante da CETESB, Sr. } \\
\text { Fábio Moreno) }\end{array}$ \\
\hline \multirow{2}{*}{$23 / 09 / 2014$} & Plano da Bacia & $\begin{array}{l}\text { Informou que foram concluídos os trabalhos da Câmara Técnica de } \\
\text { Planejamento e Articulação para o encaminhamento do Plano da Bacia, } \\
\text { estando este em fase de licitação. (Assessor do secretário de saneamento e } \\
\text { recursos hídricos, Sr. Rui Brasil) }\end{array}$ \\
\hline & Mananciais & $\begin{array}{l}\text { Discorreu que o objetivo do Grupo Técnico Leis de Mananciais era propor } \\
\text { minutas de leis de mananciais das áreas que ainda não existem e revisar as } \\
\text { leis vigentes da Guarapiranga e Billings. (Coordenador do Grupo Técnico } \\
\text { Leis de Mananciais, Sr. Amauri Pollachi) }\end{array}$ \\
\hline \multirow[t]{2}{*}{ 03/10/2014 } & Escassez hídrica & $\begin{array}{l}\text { Apresentaram as ações em curso e planejadas pelos operadores dos serviços } \\
\text { de saneamento para enfrentamento da crise hídrica: } \\
\text { Município de Santo André: representante do SEMASA, Sr. Magner Dantas; } \\
\text { Município de Mogi das Cruzes: dirigente do SEMAE, Sr. Dirceu Lorena; } \\
\text { Município de São Caetano do Sul: representante do DAE, Sr. Osmar Silva } \\
\text { Filho; } \\
\text { Município de Guarulhos: representante do SAEE, Sr. Marco Aurélio } \\
\text { Carvalho. }\end{array}$ \\
\hline & Escassez hídrica & $\begin{array}{l}\text { Discussão sobre a participação dos Comitês de Bacias no Grupo Técnico de } \\
\text { Assessoramento para Gestão do Sistema Cantareira. }\end{array}$ \\
\hline \multirow{2}{*}{$12 / 12 / 2014$} & Mananciais & $\begin{array}{l}\text { Informou que a revisão das leis específicas da Guarapiranga e Billings } \\
\text { foram concluídas. (Coordenador do Grupo Técnico Leis de Mananciais, Sr. } \\
\text { Amauri Pollachi) }\end{array}$ \\
\hline & Plano da Bacia & $\begin{array}{l}\text { Informou que devido a dois recursos de solicitação de suspenção da } \\
\text { contratação o edital seria lançado novamente. (Representante da FABHAT, } \\
\text { Sr. Francisco José de Toledo Piza) }\end{array}$ \\
\hline
\end{tabular}

Fonte: Sistema Integrado de Gerenciamento de Recursos Hídricos, compilado pela autora. 
ANEXO A - Síntese das Atas do Comitê de Bacia Hidrográfica Alto Tietê

Quadro 22 - Assuntos relevantes do ano 2015.

\begin{tabular}{|c|c|c|}
\hline Data & Tema & Detalhamento \\
\hline $12 / 03 / 2015$ & Escassez hídrica & $\begin{array}{l}\text { Apresentou dados sobre a escassez sofrida da RMSP. (Secretário Benedito } \\
\text { Braga) }\end{array}$ \\
\hline \multirow{2}{*}{$31 / 03 / 2015$} & Deliberação & Reunião com deliberações. \\
\hline & Posse & Posse de membros para a gestão 2015 a 2017. \\
\hline $13 / 05 / 2015$ & $\begin{array}{l}\text { Transposição das } \\
\text { águas entre as } \\
\text { sub-bacias } \\
\text { Billings e Alto } \\
\text { Tietê }\end{array}$ & $\begin{array}{l}\text { Apresentou a interligação entre os Sistemas Rio Grande e Alto Tietê. } \\
\text { (Superintendente de Gestão de Empreendimentos da Sabesp, Sr. Guilherme } \\
\text { Machado Paixão) }\end{array}$ \\
\hline \multirow[b]{2}{*}{$16 / 06 / 2015$} & Plano da Bacia & $\begin{array}{l}\text { Informou que em breve seria concluída a licitação conduzida pela } \\
\text { FABHAT para revisão do Plano da Bacia do Alto Tietê. }\end{array}$ \\
\hline & Escassez hídrica & $\begin{array}{l}\text { Ocorreu desconforto por parte dos integrantes do CBH-AT com a SABESP, } \\
\text { devido impossibilidade da empresa de enviar um representante que pudesse } \\
\text { informar sobre o andamento das obras e ações emergenciais, afetando a } \\
\text { reunião e as discussões sobre o tema. }\end{array}$ \\
\hline $16 / 07 / 2015$ & Escassez hídrica & $\begin{array}{l}\text { Apresentou dados sobre o andamento das obras e ações emergenciais } \\
\text { anunciadas para o enfrentamento da crise hídrica com base no relatório } \\
\text { CHESS. (Representante da SABESP, Sr. Marcos Antônio Lopes Barros) }\end{array}$ \\
\hline $13 / 08 / 2015$ & Escassez hídrica & $\begin{array}{l}\text { Apresentou dados sobre o andamento das obras e ações emergenciais para a } \\
\text { crise hídrica com ênfase nos tópicos: (I) início e conclusão das etapas, (II) } \\
\text { dimensões e principais características (III) licenciamento ambiental e } \\
\text { outorga e (IV) contratações e valores de obras. (Representante da SABESP, } \\
\text { Sr. Marcos Antônio Lopes Barros) }\end{array}$ \\
\hline \multirow{2}{*}{$16 / 09 / 2015$} & Escassez hídrica & $\begin{array}{l}\text { Apresentou 'informações sobre os processos de licenciamento ambiental e } \\
\text { as medidas mitigadoras e compensatórias adotadas para os } \\
\text { empreendimentos emergenciais para enfrentamento da crise hídrica'. } \\
\text { (Representante da CETESB, Sr. Nelson Menegon Júnior) }\end{array}$ \\
\hline & $\begin{array}{c}\text { Restauração } \\
\text { ecológica }\end{array}$ & $\begin{array}{l}\text { Apresentou sobre a restauração ecológica, colocando em pauta que a } \\
\text { proteção dos mananciais auxilia na qualidade e quantidade de água, sendo } \\
\text { uma opção mais barata do que transportar água. (Representante da } \\
\text { organização The Nature Conservancy, Sr. Samuel Barreto) }\end{array}$ \\
\hline $09 / 12 / 2015$ & Deliberação & Reunião com deliberações. \\
\hline
\end{tabular}

Fonte: Sistema Integrado de Gerenciamento de Recursos Hídricos, compilado pela autora. 
Quadro 23 - Assuntos relevantes do ano 2016.

\begin{tabular}{|c|c|c|}
\hline Data & Tema & Detalhamento \\
\hline \multirow[t]{2}{*}{$12 / 02 / 2016$} & Mananciais & $\begin{array}{l}\text { Informou sobre o recebimento do Plano Diretor da cidade de São Paulo e } \\
\text { do Projeto de Lei } 272 \text { de } 2015 \text {, que institui o parcelamento e uso de } \\
\text { ocupação do solo para análise de compatibilidade com as Leis } \\
\text { Guarapiranga e Billings. }\end{array}$ \\
\hline & Abastecimento & $\begin{array}{l}\text { Apresentou o empreendimento "Obras de aproveitamento da bacia do rio } \\
\text { Itapanhaú para abastecimento da RMSP". (Representante do Grupo de } \\
\text { Trabalho Consultas Ambientais, Sra. Marta Emerich) }\end{array}$ \\
\hline \multirow[t]{2}{*}{$17 / 03 / 2016$} & Abastecimento & $\begin{array}{l}\text { A Prefeitura de Guarulhos enviou ofício ao CBH-AT solicitando um } \\
\text { posicionamento em relação a distribuição do volume de água para } \\
\text { abastecimento. O Assunto foi encaminhado à Câmara Técnica de } \\
\text { Monitoramento Hidrológico. } \\
\text { O representante do município no comitê acrescentou falando sobre a } \\
\text { importância do tema, já que Guarulhos sofreu redução de } 30 \% \text {, enquanto na } \\
\text { RMSP foi de } 26,7 \% \text { no abastecimento em } 2015 \text {. (Sr. Edson José de Barros) }\end{array}$ \\
\hline & $\begin{array}{l}\text { Qualidade da } \\
\text { água }\end{array}$ & $\begin{array}{l}\text { Houve discussão sobre a qualidade da água e as metas progressivas de } \\
\text { enquadramento de corpos d'água. }\end{array}$ \\
\hline $03 / 05 / 2016$ & $\begin{array}{l}\text { Denúncia } \\
\text { FABHAT }\end{array}$ & Fez esclarecimentos sobre a denúncia ocorrida em março. \\
\hline $20 / 05 / 2016$ & Deliberação & Reunião com deliberações. \\
\hline \multirow{2}{*}{ 06/06/2016 } & $\begin{array}{c}\text { Monitoramento } \\
\text { da BH-AT }\end{array}$ & $\begin{array}{l}\text { Apresentou o Boletim de Monitoramento da BH-AT, a cargo da Câmara } \\
\text { Técnica de Monitoramento Hidrológico. (Coordenadora da CT-MH e } \\
\text { representante da CETESB, Sra. Lilian Perez) }\end{array}$ \\
\hline & Plano da Bacia & $\begin{array}{l}\text { Apresentou o andamento da elaboração do Plano da Bacia do Alto Tietê, a } \\
\text { cargo da FABHAT. (Representante da FABHAT, Sr. Francisco José de } \\
\text { Toledo Piza) }\end{array}$ \\
\hline $28 / 06 / 2016$ & Plano da Bacia & Informou que a FABHAT havia iniciado a elaboração do Plano da Bacia. \\
\hline \multirow{3}{*}{ 28/07/2016 } & $\begin{array}{c}\text { Uso e ocupação } \\
\text { do solo }\end{array}$ & $\begin{array}{l}\text { Apresentou empreendimento "Mapeamento Temático e Sistemático de Uso } \\
\text { e Ocupação do Solo da Bacia do Alto Tietê e da RMSP". (Representante da } \\
\text { EMPLASA, Sra. Priscila Masson). }\end{array}$ \\
\hline & $\begin{array}{l}\text { Proteção de } \\
\text { Mananciais }\end{array}$ & $\begin{array}{l}\text { Apresentou o "Plano de Desenvolvimento e Proteção Ambiental das } \\
\text { APRM". (Coordenador da Secretaria de Saneamento e Recursos } \\
\text { Hídricos/Unidade de Gestão de Programas, Sr. Ricardo Araújo) }\end{array}$ \\
\hline & $\begin{array}{l}\text { Proteção de } \\
\text { Mananciais }\end{array}$ & $\begin{array}{l}\text { Apresentou a situação da revisão e elaboração das Leis Específicas de } \\
\text { Mananciais. (Secretário do CBH-AT, Sr. Amauri Pollachi) }\end{array}$ \\
\hline $26 / 08 / 2016$ & Subcomitês & Apresentação das atividades desenvolvidas pelos subcomitês. \\
\hline $26 / 10 / 2016$ & Mananciais & $\begin{array}{l}\text { Realizou manifestação sobre o "Relatório de Monitoramento das Águas dos } \\
\text { mananciais Guarapiranga e Billings". (Coordenador da Secretaria de } \\
\text { Saneamento e Recursos Hídricos/Unidade de Gestão de Programas, Sr. } \\
\text { Ricardo Araújo) }\end{array}$ \\
\hline
\end{tabular}

Fonte: Sistema Integrado de Gerenciamento de Recursos Hídricos, compilado pela autora. 


\section{ANEXO B - Deliberações do Comitê da Bacia Hidrográfica Alto Tietê}

Quadro 1 - Deliberações do ano 1994*.

\begin{tabular}{|c|c|l|}
\hline Data & Identificação & \multicolumn{1}{|c|}{ Descrição } \\
\hline \multirow{5}{*}{$14 / 12 / 1994$} & - & $\begin{array}{l}\text { O CBH-AT firme uma posição junto ao Governo do Estado, para que haja } \\
\text { concentração de recursos nos estudos do Planão com o objetivo de } \\
\text { continuidade do projeto. }\end{array}$ \\
\cline { 2 - 4 } & - & $\begin{array}{l}\text { Encaminhar monção de repúdio às decisões judiciais que permitiam a } \\
\text { permanência da empresa Manikraft dentro da área da represa de Taiaçupeba. }\end{array}$ \\
\cline { 2 - 3 } & - & Visita técnica os membros do CBH-AT ao sistema Tietê - Billings. \\
\cline { 2 - 3 } & - & $\begin{array}{l}\text { HIDROPLAN deve apresentar os estudos sobre o sistema de tratamento de } \\
\text { água - ozonização. }\end{array}$ \\
\hline
\end{tabular}

Fonte: Sistema Integrado de Gerenciamento de Recursos Hídricos, compilado pela autora.

Nota:

* Ano não possui documento de deliberação, desta forma as mesmas foram retiradas das atas de reunião do CBH-AT. 
Quadro 2 - Deliberações do ano 1995*.

\begin{tabular}{|c|c|l|}
\hline Data & Identificação & \multicolumn{1}{|c|}{ Descrição } \\
\hline \multirow{2}{*}{$22 / 02 / 1995$} & - & $\begin{array}{l}\text { Criação da Câmara Técnica com o objetivo de definir as diretrizes e } \\
\text { encaminhar sugestões de um Plano Integrado de Intervenção do Estado, } \\
\text { Municípios e da Sociedade Civil para minimizar os problemas de enchentes na } \\
\text { região. }\end{array}$ \\
\hline \multirow{2}{*}{$19 / 09 / 1995$} & - & Criação da Câmara Técnica de revisão da Lei de Proteção de Mananciais. \\
\cline { 2 - 4 } & - & $\begin{array}{l}\text { Monção ao secretário Nakano para liberação de recursos necessários para a } \\
\text { continuidade dos trabalhos de revisão da Lei de Proteção de Mananciais. }\end{array}$ \\
\hline $26 / 10 / 1995$ & - & $\begin{array}{l}\text { Criação da Câmara Técnica vinculada ao acompanhamento dos estudos do } \\
\text { "Planão", com esforços concentrados nas questões da represa Billings. }\end{array}$ \\
\hline
\end{tabular}

Fonte: Sistema Integrado de Gerenciamento de Recursos Hídricos, compilado pela autora.

Nota:

* Ano não possui documento de deliberação, desta forma as mesmas foram retiradas das atas de reunião do CBH-AT. 
ANEXO B - Deliberações do Comitê da Bacia Hidrográfica Alto Tietê

Quadro 3 - Deliberações do ano 1996.

\begin{tabular}{|c|c|l|}
\hline Data & Identificação & \multicolumn{1}{c|}{ Descrição } \\
\hline $30 / 08 / 1996$ & $01 / 96$ & $\begin{array}{l}\text { Aprova critérios para distribuição dos recursos do FEHIDRO destinados à } \\
\text { região do CBH-AT. }\end{array}$ \\
\hline \multirow{2}{*}{$11 / 11 / 1996$} & $02 / 96$ & $\begin{array}{l}\text { Recomenda aos órgãos do Estado e dos Municípios, diretrizes gerais para a } \\
\text { regularização e ampliações do abastecimento de água potável para a Região } \\
\text { Metropolitana de São Paulo. }\end{array}$ \\
\cline { 2 - 3 } & $03 / 96$ & Indica sete projetos para solicitação de financiamento ao COFEHIDRO. \\
\hline $05 / 12 / 1996$ & $04 / 96$ & $\begin{array}{l}\text { Constitui Comissão Especial para coordenar o processo eleitoral do Comitê, } \\
\text { referente ao mandato 1997/98 e iniciar a implantação dos subcomitês de bacia. }\end{array}$ \\
\hline
\end{tabular}

Fonte: Sistema Integrado de Gerenciamento de Recursos Hídricos, compilado pela autora. 
Quadro 4 - Deliberações do ano 1997.

\begin{tabular}{|c|c|l|}
\hline Data & Identificação & \multicolumn{1}{c|}{ Descrição } \\
\hline \multirow{3}{*}{ 14/03/1997 } & $01 / 97$ & $\begin{array}{l}\text { Reorganiza as instâncias de suporte à decisão do Comitê em três Câmaras } \\
\text { Técnicas: I - Qualidade da água e proteção de mananciais; II - Drenagem e } \\
\text { controle de inundações; III - Quantidade e racionalização dos usos da água. }\end{array}$ \\
\hline \multirow{2}{*}{$23 / 06 / 1997$} & $02 / 97$ & $\begin{array}{l}\text { Aprova critérios para distribuição dos recursos do FEHIDRO destinados à } \\
\text { região do CBH-AT, para 1997. }\end{array}$ \\
\cline { 2 - 3 } & $04 / 97$ & $\begin{array}{l}\text { Constitui, junto à Secretaria Executiva do Comitê, a Câmara Técnica de } \\
\text { Planejamento. }\end{array}$ \\
\hline \multirow{2}{*}{$05 / 09 / 1997$} & $03 / 97$ & Indica projetos para serem financiados com recursos do FEHIDRO, de 1997. \\
\cline { 2 - 4 } & $05 / 97$ & $\begin{array}{l}\text { Submete ao COFEHIDRO proposta de utilização dos recursos financeiros do } \\
\text { FEHIDRO destinados ao CBH-AT. }\end{array}$ \\
\hline
\end{tabular}

Fonte: Sistema Integrado de Gerenciamento de Recursos Hídricos, compilado pela autora. 


\section{ANEXO B - Deliberações do Comitê da Bacia Hidrográfica Alto Tietê}

Quadro 5 - Deliberações do ano 1998.

\begin{tabular}{|c|c|c|}
\hline Data & Identificação & Descrição \\
\hline \multirow{4}{*}{ 20/03/1998 } & $01 / 98$ & Cria a Câmara Técnica de Saneamento. \\
\hline & $02 / 98$ & $\begin{array}{l}\text { Aprova diretrizes para o Plano de Controle de Inundações da Bacia do Alto } \\
\text { Tietê. }\end{array}$ \\
\hline & 03/98 & $\begin{array}{l}\text { Aprovar critérios para distribuição dos recursos do FEHIDRO destinados à } \\
\text { região do CBH-AT, para } 1998 \text {. }\end{array}$ \\
\hline & $04 / 98$ & $\begin{array}{l}\text { Altera a modalidade de financiamento dos pedidos referentes aos exercícios de } \\
1996 \text { e } 1997 \text {. }\end{array}$ \\
\hline \multirow[b]{2}{*}{ 08/06/1998 } & $05 / 98$ & $\begin{array}{l}\text { Homologa as indicações de pedidos de financiamento com recursos do } \\
\text { FEHIDRO, de } 1998 \text {. }\end{array}$ \\
\hline & $06 / 98$ & $\begin{array}{l}\text { Aprova moção às lideranças da Assembleia Legislativa para que haja esforço } \\
\text { para aprovação da Lei } n^{\circ} \text { 20/98, que trata da Cobrança pela Utilização da } \\
\text { Água. }\end{array}$ \\
\hline \multirow{2}{*}{ 05/08/1998 } & $07 / 98$ & $\begin{array}{l}\text { Decidi pela constituição da Agência da Bacia Hidrográfica do Alto Tietê e } \\
\text { compor Comissão Especial para cuidar da construção da agência. }\end{array}$ \\
\hline & $08 / 98$ & $\begin{array}{l}\text { Aprova critérios para distribuição dos recursos do FEHIDRO destinados à } \\
\text { região do CBH-AT, para 1998, remanescentes. }\end{array}$ \\
\hline \multirow[b]{2}{*}{ 29/09/1998 } & $09 / 98$ & Homologa o Plano Emergencial de Recuperação dos Mananciais da RMSP. \\
\hline & $10 / 98$ & $\begin{array}{l}\text { Homologar as indicações de pedidos de financiamento com recursos } \\
\text { remanescentes do FEHIDRO para } 1998 .\end{array}$ \\
\hline \multirow{4}{*}{$02 / 12 / 1998$} & $11 / 98$ & $\begin{array}{l}\text { Constitui Comissão Especial para coordenar o processo eleitoral do comitê e } \\
\text { subcomitês regionais, referente ao mandato } 1999 / 2000 \text {. }\end{array}$ \\
\hline & $12 / 98$ & $\begin{array}{l}\text { Homologa as indicações de pedidos de financiamento com recursos } \\
\text { remanescentes do FEHIDRO para 1998. }\end{array}$ \\
\hline & $13 / 98$ & $\begin{array}{l}\text { Fixa prazo para regularização de documentação administrativa de pedidos de } \\
\text { financiamento referentes a } 1996 \text { e } 1997 \text { junto ao FEHIDRO. }\end{array}$ \\
\hline & $14 / 98$ & $\begin{array}{l}\text { Aprova a destinação de recursos do FEHIDRO ao Projeto Billings para } \\
\text { implantação de modelo matemático de monitoramento de qualidade das águas. }\end{array}$ \\
\hline
\end{tabular}

Fonte: Sistema Integrado de Gerenciamento de Recursos Hídricos, compilado pela autora. 
ANEXO B - Deliberações do Comitê da Bacia Hidrográfica Alto Tietê

Quadro 6 - Deliberações do ano 1999.

\begin{tabular}{|c|c|c|}
\hline Data & Identificação & Descrição \\
\hline \multirow{5}{*}{ 03/04/1999 } & $01 / 99$ & $\begin{array}{l}\text { Aprova critérios para distribuição dos recursos do FEHIDRO destinados à } \\
\text { região do CBH-AT, para } 1999 \text {. }\end{array}$ \\
\hline & $03 / 99$ & Cria no âmbito do CBH-AT, Grupo de Integração. \\
\hline & $04 / 99$ & $\begin{array}{l}\text { Recomenda aos subcomitês o acompanhamento do Plano Emergencial de } \\
\text { Recuperação dos Mananciais e dá outras providências. }\end{array}$ \\
\hline & $02 / 99$ & Cria o Grupo Executivo de apoio, junto à Secretaria Executiva do comitê. \\
\hline & $10 / 99$ & Cria Comissão Especial de Revisão dos Estatutos do Comitê. \\
\hline \multirow{3}{*}{ 21/06/1999 } & $06 / 99$ & $\begin{array}{l}\text { Abre prazo para novas inscrições nas Câmaras Técnicas identificadas em } \\
\text { deliberação. }\end{array}$ \\
\hline & $07 / 99$ & $\begin{array}{l}\text { Aprova moção à Assembleia Legislativa sobre o Projeto de Lei } n^{\circ} 020 / 98 \text {, que } \\
\text { institui a cobrança pelo uso dos recursos hídricos. }\end{array}$ \\
\hline & $05 / 99$ & Aprova cronograma de Instalação da Agência de Bacia do Alto Tietê. \\
\hline \multirow[t]{2}{*}{ 23/08/1999 } & 08/99 & $\begin{array}{l}\text { Homologa os pedidos de financiamento com recursos do FEHIDRO para 1999, } \\
\text { que foram aprovados pelos subcomitês regionais e pela Câmara Técnica de } \\
\text { Planejamento. }\end{array}$ \\
\hline & $09 / 99$ & $\begin{array}{l}\text { Homologa parecer da Câmara Técnica de Drenagem e Controle de Inundações } \\
\text { sobre as etapas I e II do Plano de Macrodrenagem. }\end{array}$ \\
\hline \multirow{2}{*}{ 12/11/1999 } & $11 / 99$ & $\begin{array}{l}\text { Fixa prazos, inclusive para caducidade, de tramitação de pedidos de } \\
\text { financiamento com recursos do FEHIDRO. }\end{array}$ \\
\hline & $12 / 99$ & $\begin{array}{l}\text { Aprova critérios para distribuição dos recursos remanescentes do FEHIDRO } \\
\text { destinados à região do CBH-AT, para } 1999 \text {. }\end{array}$ \\
\hline
\end{tabular}

Fonte: Sistema Integrado de Gerenciamento de Recursos Hídricos, compilado pela autora. 
Quadro 7 - Deliberações do ano 2000.

\begin{tabular}{|c|c|l|}
\hline Data & Identificação & \multicolumn{1}{c|}{ Descrição } \\
\hline \multirow{2}{*}{$04 / 02 / 2000$} & $01 / 00$ & $\begin{array}{l}\text { Aprova da proposta de destinação dos recursos do FEHIDRO para o ano 2000 } \\
\text { e enviar moção ao presidente do COFEHIDRO, solicitando a revogação do } \\
\text { novo Manual e que os pedidos de financiamento indicados na deliberação }\end{array}$ \\
\hline \multirow{2}{*}{$18 / 07 / 2000$} & $03 / 00$ & $\begin{array}{l}\text { Cria Comissão Especial para regularização do Artigo 207 da Constituição do } \\
\text { Estado, que trata da compensação financeira dos Municípios. }\end{array}$ \\
\hline \multirow{2}{*}{$24 / 08 / 2000$} & $04 / 00$ & $\begin{array}{l}\text { Prorroga o prazo de execução do Plano Emergencial de Recuperação dos } \\
\text { Mananciais. }\end{array}$ \\
\hline \multirow{2}{*}{$27 / 09 / 2000$} & $05 / 00$ & $\begin{array}{l}\text { Aprova critérios e prioridades para utilização dos recursos financeiros do } \\
\text { Bacia do Alto Tietê, em 2000. }\end{array}$ \\
\hline \multirow{2}{*}{$20 / 10 / 2000$} & $06 / 00$ & $\begin{array}{l}\text { Indica de projetos a serem financiados com recursos do FEHIDRO, no ano } \\
2000 .\end{array}$ \\
\hline \multirow{2}{*}{$14 / 12 / 2000$} & $07 / 00$ & $\begin{array}{l}\text { Fixa prazos para declaração de caducidade de pedidos de financiamento do } \\
\text { FEHIDRO. }\end{array}$ \\
\cline { 2 - 3 } & $08 / 00$ & Indica de projetos a serem financiados com recursos do FEHIDRO do ano \\
\cline { 2 - 3 } & $09 / 00$ & Aprova e torna pública a “Carta por um Fórum de Gestão Metropolitana”. \\
\hline
\end{tabular}

Fonte: Sistema Integrado de Gerenciamento de Recursos Hídricos, compilado pela autora. 
Quadro 8 - Deliberações do ano 2001.

\begin{tabular}{|c|c|l|}
\hline Data & Identificação & \multicolumn{1}{c|}{ Descrição } \\
\hline \multirow{3}{*}{$30 / 08 / 2001$} & $01 / 01$ & $\begin{array}{l}\text { Aprova critérios e prioridades para utilização dos recursos financeiros do } \\
\text { FEHIDRO destinados à Unidade de Gerenciamento de Recursos Hídricos da } \\
\text { Bacia do Alto Tietê, em 2001. }\end{array}$ \\
\cline { 2 - 4 } $29 / 11 / 2001$ & $02 / 01$ & $\begin{array}{l}\text { Reconstitui a Comissão Especial para implantação da Agência da Bacia do } \\
\text { Alto Tietê. }\end{array}$ \\
\cline { 2 - 4 } & $03 / 01$ & $\begin{array}{l}\text { Autoriza a suplementação de recursos do FEHIDRO para a execução do } \\
\text { projeto “Atualização da Base Cartográfica da RMSP”. }\end{array}$ \\
\hline \multirow{3}{*}{$19 / 12 / 2001$} & $\begin{array}{l}\text { Reitera a prioridade de regulamentação da lei n }{ }^{\circ} \text { 9.866/97, de proteção de } \\
\text { mananciais, e aprova proposta de projeto de lei para alteração da Lei 1.172/76. }\end{array}$ \\
\cline { 2 - 4 } & $05 / 01$ & $\begin{array}{l}\text { Estabelecer prazo para a indicação de representantes do Estado, dos } \\
\text { Municípios e da Sociedade Civil para constituírem o Conselho Curador da } \\
\text { Agência da Bacia do Alto Tietê. }\end{array}$ \\
\hline & $\begin{array}{l}\text { Homologa a proposta de Lei Específica da Área de Proteção e Recuperação de } \\
\text { Mananciais (APRM) da Bacia Guarapiranga. }\end{array}$ \\
\hline & $\begin{array}{l}\text { Proposta de projeto de lei que altera a Lei n }{ }^{\circ} 1.172, \text { de proteção aos } \\
\text { mananciais. }\end{array}$ \\
\hline
\end{tabular}

Fonte: Sistema Integrado de Gerenciamento de Recursos Hídricos, compilado pela autora. 


\section{ANEXO B - Deliberações do Comitê da Bacia Hidrográfica Alto Tietê}

Quadro 9 - Deliberações do ano 2002.

\begin{tabular}{|c|c|c|}
\hline Data & Identificação & Descrição \\
\hline \multirow[b]{2}{*}{$19 / 04 / 2002$} & $01 / 02$ & Indica projetos a serem financiados com recursos do FEHIDRO do ano 2001. \\
\hline & $02 / 02$ & $\begin{array}{l}\text { Reiterar moção à Assembleia Legislativa pela aprovação do projeto de lei que } \\
\text { institui a cobrança pela utilização da água. }\end{array}$ \\
\hline $12 / 07 / 2002$ & $03 / 02$ & $\begin{array}{l}\text { Indica, em ordem de prioridade, lista de projetos habilitados ao Programa de } \\
\text { Despoluição de Bacias Hidrográficas, da ANA. }\end{array}$ \\
\hline \multirow{3}{*}{$17 / 09 / 2002$} & $04 / 02$ & $\begin{array}{l}\text { Dá posse ao Conselho Curador "ad hoc" da Agência da Bacia do Alto Tietê e } \\
\text { outras providências. }\end{array}$ \\
\hline & $05 / 02$ & $\begin{array}{l}\text { Recomenda ao Executivo e ao Legislativo a adoção de medidas destinadas à } \\
\text { sustentação dos mananciais. }\end{array}$ \\
\hline & $06 / 02$ & $\begin{array}{l}\text { Determina aos subcomitês e Câmaras Técnicas a elaboração de propostas } \\
\text { destinadas à sustentação econômica da produção de água. }\end{array}$ \\
\hline \multirow{3}{*}{$31 / 10 / 2002$} & 07/02 & $\begin{array}{l}\text { Aprova critérios e prioridades para utilização dos recursos financeiros do } \\
\text { FEHIDRO destinados à Unidade de Gerenciamento de Recursos Hídricos da } \\
\text { Bacia do Alto Tietê, em } 2.002 \text {, e dá outras providências. }\end{array}$ \\
\hline & $08 / 02$ & $\begin{array}{l}\text { Aprova regulamento do processo eleitoral para o biênio } 2003 \text { - 2004, reti- } \\
\text { ratificada conforme Deliberação CBH-AT, } n^{\circ} 3 \text {, de } 28 / 01 / 2003 \text {. }\end{array}$ \\
\hline & $09 / 02$ & $\begin{array}{l}\text { Aprova o Regulamento da Lei }{ }^{\circ} 11.216 \text { de } 22 \text { de julho de } 2002 \text {, que altera a } \\
\text { Lei } n^{\circ} 1.172 \text {, de } 17 \text { de novembro de } 1976 \text {, que delimita as áreas de proteção } \\
\text { dos mananciais, cursos e reservatórios de água de interesse da Região } \\
\text { Metropolitana da Grande São Paulo. }\end{array}$ \\
\hline $12 / 12 / 2002$ & $10 / 02$ & $\begin{array}{l}\text { Determina o prosseguimento das análises do EIA-RIMA do empreendimento } \\
\text { RODOANEL MÁRIO COVAS, no âmbito do CBH-AT, e propor diretrizes } \\
\text { para a participação efetiva do Comitê no processo de licenciamento do projeto, } \\
\text { entre outras providências. }\end{array}$ \\
\hline
\end{tabular}

Fonte: Sistema Integrado de Gerenciamento de Recursos Hídricos, compilado pela autora. 


\section{ANEXO B - Deliberações do Comitê da Bacia Hidrográfica Alto Tietê}

Quadro 10 - Deliberações do ano 2003.

\begin{tabular}{|c|c|c|}
\hline Data & Identificação & Descrição \\
\hline \multirow{3}{*}{$03 / 04 / 2003$} & $\begin{array}{l}\text { Inundações } \\
\text { Tietê }\end{array}$ & $\begin{array}{l}\text { Observa que o rebaixamento da calha do rio Tietê foi planejado pensando em } \\
\text { diminuir as inundações na RMSP, porém devido ao levantamento dos } \\
\text { sedimentos do fundo do rio que estavam acumulados houveram problemas no } \\
\text { Médio Tietê, levando para a região poluentes. (Presidente do CBH-AT, Sra. } \\
\text { Marta Suplicy) }\end{array}$ \\
\hline & $\begin{array}{l}\text { Projeto de } \\
\text { Despoluição } \\
\text { do Tietê }\end{array}$ & $\begin{array}{l}\text { Fez colocação sobre o projeto afirmando que já haviam atingido } 61 \text { a } 62 \% \text { de } \\
\text { tratamento dos esgotos tratados na RMSP. (Dr. Antônio Marcília) }\end{array}$ \\
\hline & $\begin{array}{l}\text { Poluição } \\
\text { difusa }\end{array}$ & $\begin{array}{l}\text { Adicionou em sua fala que a poluição difusa não é apenas de responsabilidade } \\
\text { da sociedade civil, mas também das prefeituras. (Dr. Antônio Marcília) }\end{array}$ \\
\hline $14 / 04 / 2003$ & $\begin{array}{c}\text { Recursos } \\
\text { financeiros }\end{array}$ & $\begin{array}{l}\text { Tratou dos critérios e as prioridades de aplicação de recursos do FEHIDRO } \\
\text { para o ano. }\end{array}$ \\
\hline $23 / 04 / 2003$ & $\begin{array}{l}\text { Recursos } \\
\text { financeiros }\end{array}$ & $\begin{array}{l}\text { Tratou dos critérios e as prioridades de aplicação de recursos do FEHIDRO } \\
\text { para o ano. }\end{array}$ \\
\hline \multirow[b]{2}{*}{$29 / 05 / 2003$} & $\begin{array}{l}\text { Recursos } \\
\text { financeiros }\end{array}$ & $\begin{array}{l}\text { Tratou dos critérios e as prioridades de aplicação de recursos do FEHIDRO } \\
\text { para o ano. }\end{array}$ \\
\hline & Saneamento & $\begin{array}{l}\text { Falou sobre a importância de um Projeto de Lei do Executivo Municipal de } \\
\text { São Paulo sobre regulação do saneamento, que incidiria sobre o Plano da Bacia } \\
\text { na hipótese de municipalização do serviço de saneamento. (Representante da } \\
\text { Prefeitura Municipal de São Paulo, Sra. Viviana de Aquino Borges) }\end{array}$ \\
\hline \multirow[t]{2}{*}{ 03/06/2003 } & Saneamento & $\begin{array}{l}\text { Apresentou o Projeto de Lei } \mathrm{n}^{\circ} 219 \text { da prefeitura, que visa criar a política } \\
\text { municipal de saneamento e estabelecer o sistema de regulação do serviço de } \\
\text { saneamento no município. (Representante da Prefeitura Municipal de São } \\
\text { Paulo, Sra. Andréa de Oliveira Castro) }\end{array}$ \\
\hline & $\begin{array}{l}\text { Recursos } \\
\text { financeiros }\end{array}$ & $\begin{array}{l}\text { Homologou-se os pedidos de financiamento com recursos do FEHIDRO, de } \\
2003 \text {. }\end{array}$ \\
\hline
\end{tabular}

Fonte: Sistema Integrado de Gerenciamento de Recursos Hídricos, compilado pela autora. 


\section{ANEXO B - Deliberações do Comitê da Bacia Hidrográfica Alto Tietê}

Quadro 11 - Deliberações do ano 2004.

\begin{tabular}{|c|c|c|}
\hline Data & Identificação & Descrição \\
\hline \multirow[b]{2}{*}{$19 / 02 / 2004$} & $01 / 04$ & $\begin{array}{l}\text { Dispõe sobre o plano de aplicação e distribuição de recursos do FEHIDRO } \\
\text { para o ano } 2004 \text { e dá outras providências. }\end{array}$ \\
\hline & $02 / 04$ & $\begin{array}{l}\text { Aprova critérios e prioridades para seleção de empreendimentos para } \\
\text { utilização dos recursos financeiros do FEHIDRO destinados à Unidade de } \\
\text { Gerenciamento de Recursos Hídricos da Bacia do Alto Tietê, em 2004, e dá } \\
\text { outras providências. }\end{array}$ \\
\hline $23 / 04 / 2004$ & $03 / 04$ & $\begin{array}{l}\text { Aprova critérios de pontuação para pré-seleção e hierarquização dos } \\
\text { empreendimentos a serem financiados com recursos financeiros do FEHIDRO } \\
\text { destinados ao CBH-AT, para o exercício de } 2004 \text {, e dá outras providências. }\end{array}$ \\
\hline $07 / 05 / 2004$ & $04 / 04$ & $\begin{array}{l}\text { Aprova indicação ao FEHIDRO dos empreendimentos a serem financiados } \\
\text { com recursos financeiros do fundo destinados ao CBH-AT, para o exercício de } \\
\text { 2004, e dá outras providências. }\end{array}$ \\
\hline \multirow[t]{2}{*}{ 29/06/2004 } & $05 / 04$ & $\begin{array}{l}\text { Aprova o Estudo de Impacto Ambiental e respectivo Relatório de Impacto no } \\
\text { Meio Ambiente - EIA-RIMA do Projeto de Modernização e Ampliação da } \\
\text { Usina Termoelétrica Piratininga, e dá outras providências. }\end{array}$ \\
\hline & $06 / 04$ & $\begin{array}{l}\text { Indicação ao FEHIDRO de empreendimentos a serem financiados com } \\
\text { recursos excedentes do exercício de } 2004 \text {. }\end{array}$ \\
\hline $26 / 07 / 2004$ & 07/04 & $\begin{array}{l}\text { Aprova manifestação sobre a renovação da outorga do Sistema Cantareira e dá } \\
\text { outras providências. }\end{array}$ \\
\hline $07 / 10 / 2004$ & $08 / 04$ & $\begin{array}{l}\text { Altera o proponente tomador para empreendimento do CBH-AT a ser } \\
\text { financiado com recursos financeiros do FEHIDRO, para o exercício de } 2004 \text {. }\end{array}$ \\
\hline $14 / 12 / 2004$ & $09 / 04$ & $\begin{array}{l}\text { Aprova calendário, fixar normas e constituir Comissão de Acompanhamento } \\
\text { do Processo Eleitoral para as eleições do Comitê do Alto Tietê, para o mandato } \\
\text { 2005/2007, e dá outras providências. }\end{array}$ \\
\hline
\end{tabular}

Fonte: Sistema Integrado de Gerenciamento de Recursos Hídricos, compilado pela autora. 
Quadro 12 - Deliberações do ano 2005.

\begin{tabular}{|c|c|l|}
\hline Data & Identificação & \multicolumn{1}{c|}{ Descrição } \\
\hline $15 / 03 / 2005$ & $01 / 05$ & $\begin{array}{l}\text { Aprova alteração do artigo 90 do Estatuto do Comitê da Bacia Hidrográfica do } \\
\text { Alto Tietê, CBH-AT, e dá outras providências. }\end{array}$ \\
\hline $30 / 06 / 2005$ & $04 / 05$ & $\begin{array}{l}\text { Dispõe sobre o plano de aplicação e distribuição de recursos do FEHIDRO } \\
\text { para o ano 2005, aprovar critérios e prioridades e dar prazos para seleção de } \\
\text { empreendimentos para utilização dos recursos financeiros do FEHIDRO } \\
\text { destinados à Unidade de Gerenciamento de Recursos Hídricos da Bacia do } \\
\text { Alto Tietê, em 2005, e dá outras providências. }\end{array}$ \\
\hline $06 / 07 / 2005$ & $02 / 05$ & $\begin{array}{l}\text { Aprova critérios de prioridades para pré-seleção e hierarquização dos } \\
\text { empreendimentos a serem financiados com recursos financeiros do FEHIDRO } \\
\text { destinados ao CBH-AT, para o exercício de 2005. }\end{array}$ \\
\hline $27 / 07 / 2005$ & $03 / 05$ & $\begin{array}{l}\text { Aprova indicação ao FEHIDRO dos empreendimentos a serem financiados } \\
\text { com recursos financeiros do fundo para o ano de 2005, e dá outras } \\
\text { providências. }\end{array}$ \\
\hline $14 / 09 / 2005$ & $04 / 05$ “ad \\
referendum” & $\begin{array}{l}\text { Aprova indicação dos representantes do CBH-AT ao Fórum Paulista de } \\
\text { Comitês de Bacias Hidrográficas, para o biênio 2005-2007, e dá outras } \\
\text { providências. }\end{array}$ \\
\hline
\end{tabular}

Fonte: Sistema Integrado de Gerenciamento de Recursos Hídricos, compilado pela autora. 


\section{ANEXO B - Deliberações do Comitê da Bacia Hidrográfica Alto Tietê}

Quadro 13 - Deliberações do ano 2006.

\begin{tabular}{|c|c|l|}
\hline Data & Identificação & \multicolumn{1}{c|}{ Descrição } \\
\hline 02/02/2006 & $01 / 06$ & $\begin{array}{l}\text { Aprova a manifestação da Fundação Agência da Bacia Hidrográfica do Alto } \\
\text { Tietê, sobre a implantação do Rodoanel, no âmbito da UGRHI-6, e dá outras } \\
\text { providências. }\end{array}$ \\
\hline 15/03/2006 & $02 / 06$ & $\begin{array}{l}\text { Dispõe sobre a recomposição e reorganização das Câmaras Técnicas do } \\
\text { Comitê de Bacia do Alto Tietê ao Fórum Paulista de Comitês de Bacias } \\
\text { Hidrográficas, para o biênio 2005-2007, e dá outras providências. }\end{array}$ \\
\hline 25/04/2000 & $03 / 06$ & $\begin{array}{l}\text { Aprova plano de aplicação, critérios de prioridades pontuação para pré-seleção } \\
\text { e hierarquização dos empreendimentos a serem financiados com recursos } \\
\text { financeiros do FEHIDRO destinados ao CBH-AT, para 2006, e dá outras } \\
\text { providências. }\end{array}$ \\
\hline $12 / 05 / 2006$ & $04 / 06$ "ad \\
referendum" & $\begin{array}{l}\text { Prorroga o prazo de apresentação de projetos a serem financiados com recursos } \\
\text { do FEHIDRO - exercício de 2006, no âmbito da UGRHI-6. }\end{array}$ \\
\hline \multirow{2}{*}{$19 / 05 / 2006$} & $05 / 06$ & $\begin{array}{l}\text { Indica ao Conselho Curador da Fundação Agência da Bacia Hidrográfica do } \\
\text { Alto Tietê, representante da Sociedade Civil no CBH-AT para o cargo de } \\
\text { Diretor Presidente da FABHAT. }\end{array}$ \\
\hline \multirow{2}{*}{$29 / 06 / 2006$} & $06 / 06$ & $\begin{array}{l}\text { Aprova indicação ao FEHIDRO dos empreendimentos a serem financiados } \\
\text { com recursos financeiros do FUNDO destinados ao CBH- AT, para o exercício } \\
\text { de 2006, e dá outras providências. }\end{array}$ \\
\hline \multirow{2}{*}{$19 / 12 / 2006$} & $\begin{array}{l}\text { Aprova alteração de Tomador para empreendimento a ser financiado com } \\
\text { recursos financeiros do FEHIDRO destinados ao CBH- AT, para o exercício } \\
\text { de 2006, e dá outras providências. }\end{array}$ \\
\hline $05 / 10 / 2006$ & $\begin{array}{l}\text { Aprova diretrizes para implementação da cobrança pela utilização dos recursos } \\
\text { hídricos na área de atuação do CBH-AT, e dá outras providências. }\end{array}$ \\
\cline { 2 - 4 } & $09 / 06$ & $\begin{array}{l}\text { Indica ao Conselho Curador da Fundação Agência da Bacia Hidrográfica do } \\
\text { Alto Tietê, representante da Sociedade Civil no CBH-AT para responder } \\
\text { temporariamente pelo cargo de Diretor Presidente da FABHAT. }\end{array}$ \\
\hline
\end{tabular}

Fonte: Sistema Integrado de Gerenciamento de Recursos Hídricos, compilado pela autora. 


\section{ANEXO B - Deliberações do Comitê da Bacia Hidrográfica Alto Tietê}

Quadro 14 - Deliberações do ano 2007.

\begin{tabular}{|c|c|c|}
\hline Data & Identificação & Descrição \\
\hline $19 / 03 / 2007$ & 01/07 & $\begin{array}{l}\text { Regulamenta os dispositivos da Lei Estadual } \mathrm{N}^{\circ} 12.233 \text {, de } 16 \text { de janeiro de } \\
2006 \text { - Lei Específica Guarapiranga, que define a Área de Proteção e } \\
\text { Recuperação dos Mananciais da Bacia Hidrográfica do Guarapiranga - } \\
\text { APRM-G, e dá outras providências. }\end{array}$ \\
\hline $12 / 04 / 2007$ & $\begin{array}{l}02 / 07 \text { “ad } \\
\text { referendum” }\end{array}$ & $\begin{array}{l}\text { Aprova calendário, fixa normas e constitui Comissão de Acompanhamento do } \\
\text { Processo Eleitoral, para as eleições do Comitê do Alto Tietê - mandato } \\
\text { 2007/2009, e dá outras providências. }\end{array}$ \\
\hline \multirow{3}{*}{$31 / 10 / 2007$} & 03/07 & $\begin{array}{l}\text { Dispõe sobre a homologação da nova composição das Câmaras Técnicas do } \\
\text { Comitê de Bacia do Alto Tietê e de seus coordenadores, para o biênio 2.007- } \\
2.009 \text {, e dá outras providências. }\end{array}$ \\
\hline & $04 / 07$ & $\begin{array}{l}\text { Aprova alteração de Tomador para empreendimento a ser financiado com } \\
\text { recursos financeiros do FEHIDRO destinados ao CBH- AT, exercício de } \\
2.004 \text {, e dá outras providências. }\end{array}$ \\
\hline & $05 / 07$ & Altera o artigo 14 do Estatuto do Comitê da Bacia Hidrográfica do Alto Tietê. \\
\hline $30 / 11 / 2007$ & 08/07 & $\begin{array}{l}\text { Homologa a proposta de Minuta de Lei Específica da Área de Proteção e } \\
\text { Recuperação de Mananciais do Alto Juquery - APRM-AJ }\end{array}$ \\
\hline $10 / 12 / 2007$ & 07/07 & $\begin{array}{l}\text { Homologa a proposta de Anteprojeto de Lei Específica da Área de Proteção e } \\
\text { Recuperação de Mananciais do Reservatório Billings - APRM-B }\end{array}$ \\
\hline $19 / 12 / 2007$ & $\begin{array}{l}09 / 07 \text { “ad } \\
\text { referendum” }\end{array}$ & $\begin{array}{l}\text { Aprova o processo para a implantação da cobrança pela utilização dos recursos } \\
\text { hídricos na Bacia Hidrográfica do Alto Tietê - UGRHI-6, e dá outras } \\
\text { providências. }\end{array}$ \\
\hline
\end{tabular}

Fonte: Sistema Integrado de Gerenciamento de Recursos Hídricos, compilado pela autora. 


\section{ANEXO B - Deliberações do Comitê da Bacia Hidrográfica Alto Tietê}

Quadro 15 - Deliberações do ano 2008.

\begin{tabular}{|c|c|c|}
\hline Data & Identificação & Descrição \\
\hline \multirow[t]{2}{*}{$28 / 01 / 2008$} & $01 / 08$ & $\begin{array}{l}\text { Dispõe sobre a aprovação de critérios de pontuação e hierarquização dos } \\
\text { empreendimentos a serem financiados com recursos do FEHIDRO destinados } \\
\text { ao CBH-AT, para o exercício de } 2008 \text {, e dá outras providências. }\end{array}$ \\
\hline & $02 / 08$ & $\begin{array}{l}\text { Dispõe sobre a indicação de projetos prioritários preestabelecidos (demandas } \\
\text { induzidas) pelo CBH-AT. }\end{array}$ \\
\hline \multirow[b]{2}{*}{$31 / 03 / 2008$} & $04 / 08$ & $\begin{array}{l}\text { Dispõe sobre a hierarquização e indicação de empreendimentos para } \\
\text { financiamento com recursos oriundos do Fundo Estadual de Recursos Hídricos } \\
\text { - FEHIDRO, referentes ao exercício de } 2007 / 2008 \text {, e dá outras providências. }\end{array}$ \\
\hline & $05 / 08$ & $\begin{array}{l}\text { Dispõe sobre a abertura de novo prazo para a apresentação de } \\
\text { empreendimentos para financiamento com saldo dos recursos oriundos do } \\
\text { Fundo Estadual de Recursos Hídricos - FEHIDRO, referentes ao exercício de } \\
\text { 2007/2008, e dá outras providências. }\end{array}$ \\
\hline $01 / 04 / 2008$ & 06/08 & $\begin{array}{l}\text { Correções dos valores do Anexo II da Deliberação } n^{\circ} 04 \text { de } 31 / 03 / 2008 \\
\text { referente aos recursos FEHIDRO-2008 e no valor do saldo disponível } \\
\text { mencionado na Deliberação } n^{\circ} 05 \text { de } 31 / 03 / 2008 \text {. }\end{array}$ \\
\hline $26 / 05 / 2008$ & 07/08 & $\begin{array}{l}\text { Dispõe sobre a hierarquização e indicação de empreendimentos para } \\
\text { financiamento com recursos oriundos do Fundo Estadual de Recursos Hídricos } \\
\text { - FEHIDRO, referentes ao exercício de } 2007 / 2008 \text {, com base na Deliberação } \\
\text { CBH-AT 05 de } 31.03 .2008 \text {, e dá outras providências. }\end{array}$ \\
\hline $28 / 07 / 2008$ & 08/08 & $\begin{array}{l}\text { Dispõe sobre aprovação das recomendações a serem consideradas no processo } \\
\text { de análise do EIA-RIMA do Projeto de Plano Diretor de Dutos da } \\
\text { PETROBRAS, pelo DAIA/SMA objeto de deliberação da CTPG do CBH-AT, } \\
\text { e dá outras providências. }\end{array}$ \\
\hline $10 / 10 / 2008$ & 03/08 & $\begin{array}{l}\text { Dispõe sobre a aprovação das recomendações descritas no Parecer Técnico da } \\
\text { CTPG em relação ao EIA/Rima do empreendimento Central de Tratamento de } \\
\text { Resíduos Leste - CLT, da Prefeitura Municipal de São Paulo. }\end{array}$ \\
\hline \multirow[b]{2}{*}{$14 / 10 / 2008$} & 09/08 & $\begin{array}{l}\text { Dispõe sobre a regulamentação dos procedimentos decorrentes da Resolução } \\
\text { SMA n }{ }^{\circ} 54 \text { de } 30 / 07 / 2008 \text {. }\end{array}$ \\
\hline & $10 / 08$ & $\begin{array}{l}\text { Dispõe sobre aprovação das recomendações a serem consideradas no processo } \\
\text { de análise do EIA-RIMA do Projeto Vila Florestal - Reserva Cotia, de } \\
\text { responsabilidade da empresa Alphaville Urbanismo S.A., pelo DAIA/SMA } \\
\text { objeto de deliberação da CTPG do CBH-AT, e dá outras providências. }\end{array}$ \\
\hline $05 / 11 / 2008$ & $11 / 08$ & $\begin{array}{l}\text { Dispõe sobre a expressa delegação do CBH-AT ao Subcomitê Cotia- } \\
\text { Guarapiranga para que atue como órgão colegiado do sistema de gestão da } \\
\text { APRM Guarapiranga e dá outras providências }\end{array}$ \\
\hline \multirow[t]{2}{*}{$17 / 12 / 2008$} & $12 / 08$ & $\begin{array}{l}\text { Dispõe sobre a revisão e aprovação do Plano de Bacia para o exercício de } \\
\text { 2008-2011 e indica o Plano de Ação e de investimentos 2008-1011 na Bacia } \\
\text { Hidrográfica do Alto Tietê. }\end{array}$ \\
\hline & $13 / 08$ & $\begin{array}{l}\text { Aprova o Relatório de Situação dos Recursos Hídricos da UGRHI do Alto } \\
\text { Tietê - } 2008 \text {, referente ao ano base } 2007 \text {. }\end{array}$ \\
\hline
\end{tabular}

Fonte: Sistema Integrado de Gerenciamento de Recursos Hídricos, compilado pela autora. 
Quadro 16 - Deliberações do ano 2009.

\begin{tabular}{|c|c|c|}
\hline Data & Identificação & Descrição \\
\hline $12 / 01 / 2009$ & $01 / 09$ & $\begin{array}{l}\text { Dispõe sobre a identificação da natureza das demandas, da aprovação de } \\
\text { critérios de pontuação e da hierarquização dos empreendimentos a serem } \\
\text { financiados com recursos do FEHIDRO destinados ao CBH-AT, para o } \\
\text { exercício de } 2009 \text {, e dá outras providências. }\end{array}$ \\
\hline $13 / 02 / 2009$ & 02/09 & $\begin{array}{l}\text { Procedimentos e critérios para o processo de escolha e indicação de } \\
\text { representantes no plenário do Comitê da Bacia Hidrográfica do Alto Tietê - } \\
\text { Mandato 2009/2011. }\end{array}$ \\
\hline $19 / 03 / 2009$ & $\begin{array}{l}03 / 09 \text { "ad } \\
\text { referendum" }\end{array}$ & $\begin{array}{l}\text { Prorrogação de prazo para apresentação de dos empreendimentos a serem } \\
\text { financiados com recursos do FEHIDRO destinados ao CBH-AT, para o } \\
\text { exercício de } 2009 \text {. }\end{array}$ \\
\hline $14 / 04 / 2009$ & $\begin{array}{l}05 / 09 \text { "ad } \\
\text { referendum" }\end{array}$ & $\begin{array}{l}\text { Prorrogação de prazo para apresentação dos empreendimentos a serem } \\
\text { financiados com recursos do FEHIDRO destinados ao CBH-AT, para o } \\
\text { exercício de } 2009 \text {. }\end{array}$ \\
\hline $27 / 04 / 2009$ & $04 / 09$ & $\begin{array}{l}\text { Aprova calendário, e constitui Comissão de Acompanhamento do Processo } \\
\text { Eleitoral para as eleições do Comitê do Alto Tietê e dos Subcomitês, para o } \\
\text { mandato 2009/2011, e dá outras providências. }\end{array}$ \\
\hline $05 / 06 / 2009$ & $\begin{array}{l}06 / 09 \text { "ad } \\
\text { referendum" }\end{array}$ & $\begin{array}{l}\text { Aprova transferência de recursos de investimento do FEHIDRO } 2009 \text { para a } \\
\text { subconta do FEHIDRO do Comitê da Bacia Hidrográfica do Médio } \\
\text { Paranapanema. }\end{array}$ \\
\hline $29 / 06 / 2009$ & 07/09 & $\begin{array}{l}\text { Dispõe sobre a hierarquização e indicação de empreendimentos para } \\
\text { financiamento com recursos oriundos do Fundo Estadual de Recursos Hídricos } \\
\text { - FEHIDRO, referentes ao exercício de } 2009 \text {, e dá outras providências. }\end{array}$ \\
\hline $20 / 07 / 2009$ & 08/09 & $\begin{array}{l}\text { Dispõe sobre a indicação de empreendimentos para financiamento com } \\
\text { recursos oriundos do Fundo Estadual de Recursos Hídricos - FEHIDRO, } \\
\text { referentes ao exercício de } 2009 \text {, e dá outras providências. }\end{array}$ \\
\hline $20 / 07 / 2009$ & 09/09 & $\begin{array}{l}\text { Dispõe sobre a criação da Câmara Técnica de Educação Ambiental do Comitê } \\
\text { de Bacia Hidrográfica do Alto Tietê - CBH-AT }\end{array}$ \\
\hline $20 / 07 / 2009$ & $10 / 09$ & $\begin{array}{l}\text { Elege e empossa os dirigentes do Comitê da Bacia Hidrográfica do Alto Tietê - } \\
\text { CBH-AT; e elege os representantes dos segmentos do Estado, dos Municípios } \\
\text { e da Sociedade Civil, e dá outras providências }\end{array}$ \\
\hline $11 / 09 / 2009$ & $11 / 09$ & $\begin{array}{l}\text { Dispõe sobre a hierarquização e indicação de empreendimentos para } \\
\text { financiamento com recursos oriundos do Fundo Estadual de Recursos Hídricos } \\
\text { - FEHIDRO enquadrado em Demanda Induzida sob o título "Revitalização de } \\
\begin{array}{l}\text { Bacias Hidrográficas", referentes ao exercício de } 2009 \text {, e dá outras } \\
\text { providências }\end{array}\end{array}$ \\
\hline 07/10/2009 & $12 / 09$ & $\begin{array}{l}\text { Aprova proposta dos mecanismos e valores para a cobrança pelo uso urbano e } \\
\text { industrial dos recursos hídricos na bacia hidrográfica do Alto Tietê e dá outras } \\
\text { providências. }\end{array}$ \\
\hline $07 / 10 / 2009$ & $\begin{array}{l}13 / 09 \text { "ad } \\
\text { referendum" }\end{array}$ & Lei Específica da Billings n ${ }^{\circ}$ 13.579/09 - ERRATA. \\
\hline $18 / 11 / 2009$ & $14 / 09$ & $\begin{array}{l}\text { Aprova a retificação da Deliberação CBH-AT } 12 \text {, de } 07.10 .2009 \text {, que trata dos } \\
\text { mecanismos e valores para a cobrança pelo uso urbano e industrial dos } \\
\text { recursos hídricos na bacia hidrográfica do Alto Tietê e dá outras providências. }\end{array}$ \\
\hline $18 / 11 / 2009$ & $15 / 09$ & $\begin{array}{l}\text { Dispõe sobre a homologação da nova composição das Câmaras Técnicas do } \\
\text { Comitê de Bacia do Alto Tietê, para o biênio 2009-2011, e dá outras } \\
\text { providências. }\end{array}$ \\
\hline $18 / 11 / 2009$ & $16 / 09$ & $\begin{array}{l}\text { Dispõe sobre a indicação de empreendimentos para financiamento com } \\
\text { recursos oriundos do Fundo Estadual de Recursos Hídricos - FEHIDRO, } \\
\text { referentes ao exercício de } 2009 \text {, considerando os termos da Deliberação } \\
\text { COFEHIDRO 110/2009, e dá outras providências. }\end{array}$ \\
\hline
\end{tabular}

Continua 
Quadro 16 - Deliberações do ano 2009.

Continuação

\begin{tabular}{|c|c|c|}
\hline Data & Identificação & Descrição \\
\hline $02 / 12 / 2009$ & $\begin{array}{l}17 / 09 \text { "ad } \\
\text { referendum" }\end{array}$ & $\begin{array}{l}\text { Dispõe sobre alteração do tomador do projeto 2008-AT- } 406 \text { que trata do } \\
\text { Levantamento, diagnóstico e avaliação de projetos financiados pelo } \\
\text { FEHIDRO, visando recomendações para o aprimoramento do sistema, cujo } \\
\text { tomador é a Secretaria de Estado de Meio Ambiente, e dá outras providências. }\end{array}$ \\
\hline $18 / 12 / 2009$ & $18 / 09$ & $\begin{array}{l}\text { Aprova a retificação do artigo } 9^{\circ} \text { da Deliberação CBH-AT } \mathrm{n}^{\circ} 12 \text {, de } \\
07.10 .2009 \text {, que trata dos mecanismos e valores para a cobrança pelo uso } \\
\text { urbano e industrial dos recursos hídricos na bacia hidrográfica do Alto Tietê e } \\
\text { dá outras providências. }\end{array}$ \\
\hline $18 / 12 / 2009$ & $19 / 09$ & $\begin{array}{l}\text { Dispõe sobre a atualização do Plano de Bacia Hidrográfica do Alto Tietê para } \\
\text { o exercício de 2008-2011 aprovado pela Deliberação CBH-AT n }{ }^{\circ} 12 / 2008 \text {. }\end{array}$ \\
\hline $18 / 12 / 2009$ & $20 / 09$ & $\begin{array}{l}\text { Aprova o Relatório de Situação dos Recursos Hídricos da Bacia Hidrográfica } \\
\text { do Alto Tietê }-2009 \text {, referente ao ano base } 2008 \text {. }\end{array}$ \\
\hline $18 / 12 / 2009$ & $21 / 09$ & $\begin{array}{l}\text { Dispõe sobre a identificação da natureza das demandas, da aprovação de } \\
\text { critérios de pontuação e da hierarquização dos empreendimentos a serem } \\
\text { financiados com recursos do FEHIDRO destinados ao CBH-AT, para o } \\
\text { exercício de } 2010 \text {, e dá outras providências. }\end{array}$ \\
\hline
\end{tabular}

Fonte: FEHIDRO, 2017, compilado pela autora. 
Quadro 17 - Deliberações do ano 2010.

\begin{tabular}{|c|c|l|}
\hline Data & Identificação & \multicolumn{1}{c|}{ Descrição } \\
\hline $29 / 03 / 2010$ & $01 / 10$ & $\begin{array}{l}\text { Aprova calendário para as eleições do Comitê do Alto Tietê e dos Subcomitês, } \\
\text { referentes aos cargos titulares e suplentes em vacância, para o mandato } \\
\text { 2009/2011, e dá outras providências. }\end{array}$ \\
\hline $26 / 05 / 2010$ & $02 / 10$ & $\begin{array}{l}\text { Aprova transferência de recursos de investimento do FEHIDRO 2010 para a } \\
\text { sub- conta do FEHIDRO do Comitê da Bacia Hidrográfica do Médio } \\
\text { Paranapanema }\end{array}$ \\
\hline $26 / 05 / 2010$ & $03 / 10$ & $\begin{array}{l}\text { Dispõe sobre a hierarquização e indicação de empreendimentos para } \\
\text { financiamento com recursos oriundos do Fundo Estadual de Recursos Hídricos } \\
\text { - FEHIDRO, referentes ao exercício de 2010, e dá outras providências. }\end{array}$ \\
\hline $18 / 11 / 2010$ & $04 / 10$ & $\begin{array}{l}\text { Elege os representantes do segmento da sociedade civil para os cargos em } \\
\text { vacância do Comitê da Bacia Hidrográfica do Alto Tietê e dos Subcomitês - } \\
\text { Biênio 2009-2011, e dá outras providências. }\end{array}$ \\
\hline $18 / 11 / 2010$ & $05 / 10$ & $\begin{array}{l}\text { Dispõe sobre a indicação de empreendimentos para financiamento com } \\
\text { recursos oriundos do Fundo Estadual de Recursos Hídricos - FEHIDRO, } \\
\text { referentes ao exercício de 2010. }\end{array}$ \\
\hline $16 / 12 / 2010$ & $06 / 10$ & $\begin{array}{l}\text { Aprova o Relatório de Situação dos Recursos Hídricos da Bacia Hidrográfica } \\
\text { do Alto Tietê - 2010. }\end{array}$ \\
\hline
\end{tabular}

Fonte: FEHIDRO, 2017, compilado pela autora. 


\section{ANEXO B - Deliberações do Comitê da Bacia Hidrográfica Alto Tietê}

Quadro 18 - Deliberações do ano 2011.

\begin{tabular}{|c|c|c|}
\hline Data & Identificação & Descrição \\
\hline $16 / 02 / 2011$ & $01 / 11$ & $\begin{array}{l}\text { Que estabelece áreas de restrição e controle para a captação e uso das águas } \\
\text { subterrâneas no município de São Paulo, na região de Jurubatuba e dá outras } \\
\text { providências. }\end{array}$ \\
\hline $16 / 02 / 2011$ & $02 / 11$ & $\begin{array}{l}\text { Aprova calendário, e constitui Comissão de Acompanhamento do Processo } \\
\text { Eleitoral para as eleições do Comitê do Alto Tietê e dos Subcomitês, para o } \\
\text { mandato 2011/2013, e dá outras providências. }\end{array}$ \\
\hline $16 / 02 / 2011$ & 03/11 & $\begin{array}{l}\text { Procedimentos e critérios para o processo de escolha, indicação e atualização } \\
\text { de cadastro de representantes no plenário do Comitê da Bacia Hidrográfica do } \\
\text { Alto Tietê - Mandato 2011/2013. }\end{array}$ \\
\hline $16 / 02 / 2011$ & $04 / 11$ & $\begin{array}{l}\text { Dispõe sobre alteração do tomador do projeto 2009-AT-479 que trata do } \\
\text { "Plano de Desenvolvimento Regional dos Mananciais do Sub Comitê Alto } \\
\text { Tiete Cabeceiras: PDPA e assessoria para elaboração das Leis Específicas", } \\
\text { cujo tomador é a Fundação de Apoio ao Instituto de Pesquisa tecnológica - } \\
\text { FIPT, e dá outras providências. }\end{array}$ \\
\hline $16 / 02 / 2011$ & $05 / 11$ & $\begin{array}{l}\text { Dispõe sobre a identificação da natureza das demandas, da aprovação de } \\
\text { critérios de pontuação e da hierarquização dos empreendimentos a serem } \\
\text { financiados com recursos do FEHIDRO destinados ao CBH-AT, para o } \\
\text { exercício de } 2011 \text {, e dá outras providências. }\end{array}$ \\
\hline $31 / 03 / 2011$ & $06 / 11$ & $\begin{array}{l}\text { Elege e empossa os dirigentes do Comitê da Bacia Hidrográfica do Alto Tietê } \\
\text { - CBH-AT; e elege os representantes dos segmentos Estado, Município e } \\
\text { Sociedade Civil para o biênio 2011-2013, e dá outras providências. }\end{array}$ \\
\hline $13 / 04 / 2011$ & $\begin{array}{l}07 / 11 \text { "ad } \\
\text { referendum" }\end{array}$ & $\begin{array}{l}\text { Prorroga o prazo para entrega de projetos FEHIDRO no CBH-AT, ano de } \\
\text { 2011. }\end{array}$ \\
\hline $20 / 04 / 2011$ & 08/11 & $\begin{array}{l}\text { Aprova calendário para as eleições do Comitê do Alto Tietê e dos Subcomitês, } \\
\text { referentes aos cargos titulares e suplentes em vacância, para o mandato } \\
\text { 2011/2013, e dá outras providências. }\end{array}$ \\
\hline $20 / 04 / 2011$ & 09/11 & $\begin{array}{l}\text { Trata da alteração de estrutura e funcionamento das Câmaras Técnicas do } \\
\text { CBH-AT. }\end{array}$ \\
\hline $20 / 04 / 2011$ & $10 / 11$ & $\begin{array}{l}\text { Estabelece o cronograma da Cobrança pelo Uso da Água na Bacia } \\
\text { Hidrográfica do Alto Tietê para os anos de } 2011-2012 \text {. }\end{array}$ \\
\hline $30 / 06 / 2011$ & $11 / 11$ & $\begin{array}{l}\text { Aprova transferência de recursos de investimento do FEHIDRO } 2011 \text { para a } \\
\text { subconta do FEHIDRO do Comitê da Bacia Hidrográfica do Médio } \\
\text { Paranapanema. }\end{array}$ \\
\hline $30 / 06 / 2011$ & $12 / 11$ & $\begin{array}{l}\text { Elege os representantes do segmento da sociedade civil para os cargos em } \\
\text { vacância do Comitê da Bacia Hidrográfica do Alto Tietê e dos Subcomitês - } \\
\text { Biênio 20011-2013, e dá outras providências. }\end{array}$ \\
\hline $30 / 06 / 2011$ & $13 / 11$ & $\begin{array}{l}\text { Dispõe sobre a hierarquização e indicação de empreendimentos para } \\
\text { financiamento com recursos oriundos do Fundo Estadual de Recursos Hídricos } \\
\text { - FEHIDRO, referentes ao exercício de } 2011 \text {, e dá outras providências. }\end{array}$ \\
\hline $13 / 07 / 2011$ & $\begin{array}{l}14 / 11 \text { "ad } \\
\text { referendum" }\end{array}$ & $\begin{array}{l}\text { Dispõe sobre alteração do tomador do projeto } 2008 \text { AT- } 405 \text { que trata do } \\
\text { "Plano de Comunicação e de Informação para o Comitê da Bacia Hidrográfica } \\
\text { do Alto Tietê" cujo o tomador é a Secretaria de Estado do Meio Ambiente, e dá } \\
\text { outras providências. }\end{array}$ \\
\hline $15 / 09 / 2011$ & $\begin{array}{l}15 / 11 \text { “ad } \\
\text { referendum" }\end{array}$ & $\begin{array}{l}\text { Indica } 02 \text { (dois) representantes para participar do Projeto: Desenvolvimento de } \\
\text { Capacidades da Sociedade Civil: Ampliando a atuação nos Comitês de Bacias } \\
\text { Hidrográficas. }\end{array}$ \\
\hline 06/10/2011 & $16 / 11$ & $\begin{array}{l}\text { Dispõe sobre a hierarquização e indicação de empreendimentos para } \\
\text { financiamento com recursos oriundos do Fundo Estadual de Recursos Hídricos } \\
\text { - FEHIDRO, referentes ao exercício de } 2011 \text {, e dá outras providências. }\end{array}$ \\
\hline $14 / 12 / 2011$ & $17 / 11$ & $\begin{array}{l}\text { Aprova o Relatório de Situação dos Recursos Hídricos da Bacia Hidrográfica } \\
\text { do Alto Tietê - } 2011 \text {. }\end{array}$ \\
\hline
\end{tabular}


Quadro 18 - Deliberações do ano 2011.

Continuação

\begin{tabular}{|c|c|l|c|}
\hline Data & Identificação & \multicolumn{1}{|c|}{ Descrição } \\
\hline $14 / 12 / 2011$ & $\begin{array}{c}18 / 11 \text { "ad } \\
\text { referendum" }\end{array}$ & $\begin{array}{l}\text { Dispõe sobre a hierarquização e indicação de empreendimentos para } \\
\text { financiamento com recursos oriundos do Fundo Estadual de Recursos Hídricos } \\
\text { - FEHIDRO, referentes ao exercício de 2011, e dá outras providências. }\end{array}$ \\
\hline 27/12/2011 & $\begin{array}{c}19 / 11 \text { "ad } \\
\text { referendum" }\end{array}$ & $\begin{array}{l}\text { Estabelece o cronograma da Cobrança pelo Uso da Água na Bacia } \\
\text { Hidrográfica do Alto Tietê para os anos de 2011-2012. }\end{array}$ \\
\hline
\end{tabular}

Fonte: FEHIDRO, 2017, compilado pela autora. 


\section{ANEXO B - Deliberações do Comitê da Bacia Hidrográfica Alto Tietê}

Quadro 19 - Deliberações do ano 2012.

\begin{tabular}{|c|c|l|c|}
\hline Data & Identificação & \multicolumn{1}{|c|}{ Descrição } \\
\hline $12 / 03 / 2012$ & $01 / 12$ & $\begin{array}{l}\text { Dispõe sobre a identificação da natureza das demandas, da aprovação de } \\
\text { critérios de pontuação e da hierarquização dos empreendimentos a serem } \\
\text { financiados com recursos do FEHIDRO destinados ao CBH-AT, para o } \\
\text { exercício de 2012, e dá outras providências. }\end{array}$ \\
\hline $12 / 03 / 2012$ & $02 / 12$ & $\begin{array}{l}\text { Estabelece o cronograma da Cobrança pelo Uso da Água na Bacia } \\
\text { Hidrográfica do Alto Tietê para os anos de 2011-2012. }\end{array}$ \\
\hline $29 / 05 / 2012$ & $\begin{array}{l}03 / 12 \text { "ad } \\
\text { referendum" }\end{array}$ & $\begin{array}{l}\text { Dispõe sobre a prorrogação do prazo para apresentação e protocolo de } \\
\text { propostas de empreendimentos a serem financiados com recursos do } \\
\text { FEHIDRO destinados ao CBH-AT, para o exercício de 2012, e dá outras } \\
\text { providências. }\end{array}$ \\
\hline $09 / 08 / 2012$ & $\begin{array}{l}\text { Aprova a minuta de lei que altera dispositivos da Lei 5.555, de 08 de julho de } \\
\text { referendum" } \\
\text { 2011, que institui a compatibilização da Lei 4.791, de 18 de setembro de 2004, } \\
\text { o Plano Diretor da Estância Turística de Ribeirão Pires, com a Lei Estadual 13. } \\
579, \text { de 13 de julho de 2009, e dá outras providências. }\end{array}$ \\
\hline $09 / 08 / 2012$ & $\begin{array}{l}\text { 05/12 "ad } \\
\text { referendum" }\end{array}$ & $\begin{array}{l}\text { Aprova transferência de recursos do FEHIDRO para investimento em 2012 } \\
\text { para a subconta do FEHIDRO do Comitê da Bacia Hidrográfica do Médio } \\
\text { Paranapanema. }\end{array}$ \\
\hline $28 / 11 / 2012$ & $\begin{array}{l}\text { Dispõe sobre a indicação de empreendimentos para financiamento com } \\
\text { recursos oriundos do Fundo Estadual de Recursos Hídricos - FEHIDRO, } \\
\text { referentes ao exercício de 2012, e dá outras providências. }\end{array}$ \\
\hline
\end{tabular}

Fonte: FEHIDRO, 2017, compilado pela autora. 
Quadro 20 - Deliberações do ano 2013.

\begin{tabular}{|c|c|c|}
\hline Data & Identificação & Descrição \\
\hline 27/03/2013 & $01 / 13$ & $\begin{array}{l}\text { Aprova aditamento de recursos do Contrato FEHIDRO 194/2011, referente ao } \\
\text { empreendimento FEHIDRO 2011-AT-553 - PDPA dos Mananciais do } \\
\text { Subcomitê Alto Tietê-Cabeceiras e Assessoria para Elaboração das } \\
\text { Respectivas Leis Específicas. }\end{array}$ \\
\hline $04 / 06 / 2013$ & $02 / 13$ & $\begin{array}{l}\text { Aprova a reforma do Estatuto do Comitê da Bacia Hidrográfica do Alto Tietê - } \\
\text { CBH-AT, e dá outras providências. }\end{array}$ \\
\hline $13 / 06 / 2013$ & $03 / 13$ & $\begin{array}{l}\text { Aprova o calendário eleitoral, os procedimentos para cadastramento, eleição e } \\
\text { indicação dos representantes das entidades do segmento "Sociedade Civil" } \\
\text { para o mandato 2013-2015. }\end{array}$ \\
\hline $13 / 06 / 2013$ & $04 / 13$ & $\begin{array}{l}\text { Aprova a transferência de recursos de investimento do FEHIDRO } 2013 \text { para a } \\
\text { realização do XI Diálogo Interbacias de Educação Ambiental em Recursos } \\
\text { Hídricos. }\end{array}$ \\
\hline $05 / 06 / 2013$ & $05 / 13$ & Aprova alteração no Edital anexo à Deliberação CBH-AT nº 03, de 2013. \\
\hline $23 / 08 / 2013$ & $06 / 13$ & Aprova novo cronograma para implementação da cobrança pelo uso da água. \\
\hline $23 / 08 / 2013$ & $07 / 13$ & $\begin{array}{l}\text { Dispõe acerca das Normas Gerais de funcionamento das Câmaras Técnicas e } \\
\text { dá outras providências. }\end{array}$ \\
\hline $23 / 08 / 2013$ & $08 / 13$ & $\begin{array}{l}\text { Aprova diretrizes para os Regimentos Internos dos Subcomitês de Bacia } \\
\text { Hidrográfica e dá outras providências. }\end{array}$ \\
\hline $23 / 08 / 2013$ & $09 / 13$ & $\begin{array}{l}\text { Aprova diretrizes gerais, calendário de ações e resumo de empreendimentos a } \\
\text { serem indicados ao FEHIDRO com recursos de } 2013 \text {. }\end{array}$ \\
\hline $30 / 08 / 2013$ & $10 / 13$ & $\begin{array}{l}\text { Elege a Diretoria, as representações para o CRH, o Conselho Estadual de } \\
\text { Saneamento - CONESAN, os Conselhos Deliberativo e Fiscal da FABHAT e } \\
\text { dá outras providências. }\end{array}$ \\
\hline $30 / 08 / 2013$ & $11 / 13$ & Cria a Câmara Técnica de Planejamento e Articulação - CTPA. \\
\hline $30 / 08 / 2013$ & $12 / 13$ & Cria a Câmara Técnica de Gestão de Investimentos - CTGI. \\
\hline $30 / 08 / 2013$ & $13 / 13$ & Atribui atividades e estabelece prazos às Câmaras Técnicas CT-PA e CT-GI. \\
\hline $01 / 10 / 2013$ & $14 / 13$ & $\begin{array}{l}\text { Indica empreendimentos para financiamento do FEHIDRO com recursos de } \\
2013 \text {. }\end{array}$ \\
\hline $01 / 10 / 2013$ & $15 / 13$ & Aprova os Regimentos Internos dos Subcomitês. \\
\hline $01 / 10 / 2013$ & $16 / 13$ & $\begin{array}{l}\text { Aprova cadastramento complementar de entidades do segmento "Sociedade } \\
\text { Civil" para os Subcomitês referente ao mandato 2013-2015 e define normas de } \\
\text { eleição. }\end{array}$ \\
\hline $07 / 11 / 2013$ & $17 / 13$ & $\begin{array}{l}\text { Aprova manifestação sobre a renovação da outorga do Sistema Cantareira em } \\
2014 \text {. }\end{array}$ \\
\hline $07 / 11 / 2013$ & $18 / 13$ & $\begin{array}{l}\text { Aprova alteração dos quantitativos do contrato para execução do PDPA Alto } \\
\text { Tietê Cabeceiras e Assessoria para Leis Específicas (empreendimento } \\
\text { FEHIDRO AT-553). }\end{array}$ \\
\hline $25 / 11 / 2013$ & $19 / 13$ & Aprova a alteração de escopo do empreendimento FEHIDRO AT-48. \\
\hline $18 / 12 / 2013$ & $20 / 13$ & $\begin{array}{l}\text { Aprova alteração no calendário para eleição e posse dos representantes nos } \\
\text { Subcomitês e dá outras providências. }\end{array}$ \\
\hline $18 / 12 / 2013$ & $21 / 13$ & $\begin{array}{l}\text { Aprova a proposta de Anteprojeto de Lei Específica da Área de Proteção e } \\
\text { Recuperação dos Mananciais do Alto Tietê Cabeceiras - APRM-ATC. }\end{array}$ \\
\hline $18 / 12 / 2013$ & $22 / 13$ & $\begin{array}{l}\text { Aprova parecer técnico sobre considerações da DERSA acerca da Deliberação } \\
\text { do CBH-AT de } 16 / 12 / 10 \text { referente ao EIA/RIMA do "Rodoanel Trecho-Norte" } \\
\text { e dá outras providências. }\end{array}$ \\
\hline $18 / 12 / 2013$ & $23 / 13$ & $\begin{array}{l}\text { Aprova parecer técnico sobre o EIA/RIMA do "Loteamento Residencial Santa } \\
\text { Maria III", no município de Jandira. }\end{array}$ \\
\hline $18 / 12 / 2013$ & $24 / 13$ & $\begin{array}{l}\text { Aprova parecer técnico sobre o EIA/RIMA da Ampliação da Extração e } \\
\text { Beneficiamento de Caulim, no município de Embu-Guaçu. }\end{array}$ \\
\hline $18 / 12 / 2013$ & $25 / 13$ & $\begin{array}{l}\text { Aprova parecer técnico sobre o EIA/RIMA do "Aterro Sanitário - Prefeitura } \\
\text { Municipal de Osasco". }\end{array}$ \\
\hline
\end{tabular}


Quadro 20 - Deliberações do ano 2013.

Continuação

\begin{tabular}{|c|c|l|}
\hline Data & Identificação & \multicolumn{1}{c|}{ Descrição } \\
\hline $18 / 12 / 2013$ & $26 / 13$ & $\begin{array}{l}\text { Aprova o Relatório de Situação dos Recursos da Bacia Hidrográfica do Alto } \\
\text { Tietê 2012, ano base 2011. }\end{array}$ \\
\hline $18 / 12 / 2013$ & $27 / 13$ & $\begin{array}{l}\text { Aprova o Relatório de Situação dos Recursos da Bacia Hidrográfica do Alto } \\
\text { Tietê 2013, ano base 2012. }\end{array}$ \\
\hline $18 / 12 / 2013$ & $28 / 13$ & $\begin{array}{l}\text { Aprova diretrizes gerais para critérios de hierarquização e calendário para } \\
\text { indicação de empreendimentos ao FEHIDRO com recursos do orçamento de } \\
2014 .\end{array}$ \\
\hline
\end{tabular}

Fonte: FEHIDRO, 2017, compilado pela autora. 


\section{ANEXO B - Deliberações do Comitê da Bacia Hidrográfica Alto Tietê}

Quadro 21 - Deliberações do ano 2014.

\begin{tabular}{|c|c|c|}
\hline Data & Identificação & Descrição \\
\hline $05 / 02 / 2014$ & $01 / 14$ & $\begin{array}{l}\text { Aprova segunda manifestação sobre a renovação da outorga do Sistema } \\
\text { Cantareira em } 2014 \text { e dá outras providências. }\end{array}$ \\
\hline $26 / 05 / 2014$ & $02 / 14$ & $\begin{array}{l}\text { Aprova parecer técnico sobre o EIA/RIMA do Aeródromo Harpia Ltda., no } \\
\text { município de São Paulo. }\end{array}$ \\
\hline $26 / 05 / 2014$ & $03 / 14$ & $\begin{array}{l}\text { Aprova parecer técnico sobre o EIA/RIMA da Ampliação da Pedreira Itapeti, } \\
\text { no município de Mogi das Cruzes. }\end{array}$ \\
\hline $26 / 05 / 2014$ & $04 / 14$ & $\begin{array}{l}\text { Aprova parecer técnico sobre o EIA/RIMA da Ampliação da CTL Ecourbis, no } \\
\text { município de São Paulo. }\end{array}$ \\
\hline $26 / 05 / 2014$ & $05 / 14$ & $\begin{array}{l}\text { Aprova parecer técnico sobre o EIA/RIMA do Sistema de Processamento e } \\
\text { Aproveitamento de Resíduos e Unidade de Recuperação de Energia (SPAR- } \\
\text { URE) - São Bernardo do Campo. }\end{array}$ \\
\hline $26 / 05 / 2014$ & $06 / 14$ & Aprova Plano de Trabalho para as instâncias do CBH-AT. \\
\hline $26 / 05 / 2014$ & $07 / 14$ & $\begin{array}{l}\text { Aprova providências para a criação de Câmara Técnica de Monitoramento } \\
\text { Hidrológico - CTMH. }\end{array}$ \\
\hline $26 / 05 / 2014$ & $08 / 14$ & $\begin{array}{l}\text { Aprova a criação de Grupo de Trabalho de Gestão da Demanda (GTGD) no } \\
\text { âmbito da CTPA. }\end{array}$ \\
\hline $26 / 05 / 2014$ & $09 / 14$ & $\begin{array}{l}\text { Aprova critérios de hierarquização de empreendimentos para indicações ao } \\
\text { FEHIDRO e altera calendário do processo de } 2014 \text {. }\end{array}$ \\
\hline $26 / 05 / 2014$ & $10 / 14$ & Aprova reindicação do empreendimento 2013-AT-625 ao FEHIDRO. \\
\hline $26 / 05 / 2014$ & $11 / 14$ & $\begin{array}{l}\text { Aprova a transferência de recursos de investimento do FEHIDRO } 2014 \text { para } \\
\text { apoio à realização do XII Diálogo Interbacias de Educação Ambiental em } \\
\text { Recursos Hídricos. }\end{array}$ \\
\hline $23 / 09 / 2014$ & $12 / 14$ & $\begin{array}{l}\text { Retifica e complementa a Deliberação CBH-AT n }{ }^{\circ} 09 \text {, de } 26 \text { de maio de } 2014 \text {, } \\
\text { e dá outras providências. }\end{array}$ \\
\hline 23/09/2014 & $13 / 14$ & $\begin{array}{l}\text { Aprova parecer técnico sobre o EIA/RIMA do Projeto Logum -Trecho Paulínia } \\
\text { - RMSP - Santos. }\end{array}$ \\
\hline 23/09/2014 & $14 / 14$ & $\begin{array}{l}\text { Indica empreendimentos para financiamento do FEHIDRO com recursos do } \\
\text { orçamento de } 2014 \text { e dá outras providências. }\end{array}$ \\
\hline $12 / 12 / 2014$ & $15 / 14$ & Aprova parecer técnico sobre o EIA/RIMA do Loteamento Paiva Ramos. \\
\hline $12 / 12 / 2014$ & $16 / 14$ & $\begin{array}{l}\text { Aprova o Relatório de Situação dos Recursos Hídricos da Bacia Hidrográfica } \\
\text { do Alto Tietê } 2014 \text {, ano base } 2013 \text {. }\end{array}$ \\
\hline $12 / 12 / 2014$ & $17 / 14$ & Aprova proposta de ações para gestão da demanda. \\
\hline $12 / 12 / 2014$ & $18 / 14$ & $\begin{array}{l}\text { Revoga a Deliberação CBH-AT n }{ }^{\circ} 11 \text {, de } 05 \text { de novembro de } 2008 \text {, e dá outras } \\
\text { providências. }\end{array}$ \\
\hline $12 / 12 / 2014$ & $19 / 14$ & $\begin{array}{l}\text { Aprova procedimentos para atualização cadastral ou cadastramento, eleição, } \\
\text { calendário eleitoral e indicação dos representantes das entidades da Sociedade } \\
\text { Civil para o mandato 2015-2017. }\end{array}$ \\
\hline
\end{tabular}

Fonte: FEHIDRO, 2017, compilado pela autora. 


\section{ANEXO B - Deliberações do Comitê da Bacia Hidrográfica Alto Tietê}

Quadro 22 - Deliberações do ano 2015.

\begin{tabular}{|c|c|c|}
\hline Data & Identificação & Descrição \\
\hline $12 / 03 / 2015$ & $01 / 15$ & $\begin{array}{l}\text { Aprova parecer técnico sobre o EIA/RIMA do Plano Diretor de Mineração - } \\
\text { PDM da Unidade Itapecerica da Serra, da Votorantim Cimentos. }\end{array}$ \\
\hline $12 / 03 / 2015$ & $02 / 15$ & $\begin{array}{l}\text { Aprova parecer técnico sobre o EIA/RIMA do Projeto Vila Florestal - Reserva } \\
\text { Cotia. }\end{array}$ \\
\hline $12 / 03 / 2015$ & $03 / 15$ & $\begin{array}{l}\text { Aprova o Parecer Técnico sobre a compatibilidade do Plano Diretor do } \\
\text { Município de São Bernardo do Campo, estabelecido pela Lei municipal } 6.184 \text {, } \\
\text { de } 21 \text { de dezembro de } 2011 \text {, com a Lei estadual } 13.579 \text {, de } 13 \text { de julho de } \\
2009 \text {, e dá outras providências. }\end{array}$ \\
\hline $31 / 03 / 15$ & $04 / 15$ & $\begin{array}{l}\text { Aprova alterações no Estatuto do Comitê da Bacia Hidrográfica do Alto Tietê - } \\
\text { CBH-AT, de } 4 \text { de junho de } 2013 \text {, e dá outras providências. }\end{array}$ \\
\hline $31 / 03 / 2015$ & $05 / 15$ & Cria a Câmara Técnica de Monitoramento Hidrológico - CTMH. \\
\hline $31 / 03 / 2015$ & $06 / 15$ & $\begin{array}{l}\text { Aprova o plano de trabalho, as premissas e proposta orçamentária anual da } \\
\text { Fundação Agência da Bacia Hidrográfica do Alto Tietê para o exercício 2015, } \\
\text { e dá outras providências. }\end{array}$ \\
\hline $31 / 03 / 2015$ & $07 / 15$ & $\begin{array}{l}\text { Aprova o remanejamento de vagas entre as categorias dos representantes do } \\
\text { segmento Sociedade Civil nos Subcomitês e dá outras providências }\end{array}$ \\
\hline $31 / 03 / 2015$ & $08 / 15$ & $\begin{array}{l}\text { Elege a Diretoria, os representantes para as Câmaras Técnicas, o CRH, o } \\
\text { CONESAN e os Conselhos Deliberativo e Fiscal da FABHAT, e dá outras } \\
\text { providências. }\end{array}$ \\
\hline $13 / 05 / 2015$ & $09 / 15$ & $\begin{array}{l}\text { Aprova critérios de hierarquização de empreendimentos para indicações ao } \\
\text { FEHIDRO e estabelece o calendário do processo de } 2015 \text {. }\end{array}$ \\
\hline $13 / 05 / 2015$ & $/ 15$ & Estabelece critérios para numeração das manifestações do CBH-AT. \\
\hline $16 / 06 / 2015$ & $11 / 15$ & Complementa a Deliberação CBH-AT nº 8, de 31 de março de 2015. \\
\hline $16 / 06 / 2015$ & $12 / 15$ & $\begin{array}{l}\text { Aprova a transferência de recursos de investimento do FEHIDRO } 2015 \text { para } \\
\text { apoio à realização do XIII Diálogo Interbacias de Educação Ambiental em } \\
\text { Recursos Hídricos. }\end{array}$ \\
\hline $16 / 06 / 2015$ & $13 / 15$ & $\begin{array}{l}\text { Aprova a alteração de escopo do empreendimento FEHIDRO AT-414, contrato } \\
\text { FEHIDRO no } 45 / 2009 \text {. }\end{array}$ \\
\hline $16 / 07 / 2015$ & $14 / 15$ & $\begin{array}{l}\text { Indica empreendimentos para financiamento do FEHIDRO com recursos do } \\
\text { orçamento de } 2015 \text { e dá outras providências. }\end{array}$ \\
\hline $13 / 08 / 2015$ & $15 / 15$ & $\begin{array}{l}\text { Aprova manifestação sobre a renovação da outorga do Sistema Cantareira em } \\
2015 .\end{array}$ \\
\hline $09 / 12 / 2015$ & $16 / 15$ & $\begin{array}{l}\text { Aprova o plano de trabalho, as premissas e a proposta orçamentária anual da } \\
\text { Fundação Agência da Bacia Hidrográfica do Alto Tietê para o exercício 2016, } \\
\text { e dá outras providências. }\end{array}$ \\
\hline $09 / 12 / 2015$ & $17 / 15$ & $\begin{array}{l}\text { Aprova o Relatório de Situação dos Recursos Hídricos da Bacia Hidrográfica } \\
\text { do Alto Tietê } 2015 \text {, ano base } 2014 \text {. }\end{array}$ \\
\hline $09 / 12 / 2015$ & $18 / 15$ & $\begin{array}{l}\text { Aprova diretrizes gerais para a indicação de empreendimentos ao FEHIDRO } \\
\text { com recursos do orçamento de } 2016 \text {. }\end{array}$ \\
\hline
\end{tabular}

Fonte: FEHIDRO, 2017, compilado pela autora. 


\section{ANEXO B - Deliberações do Comitê da Bacia Hidrográfica Alto Tietê}

Quadro 23 - Deliberações do ano 2016.

\begin{tabular}{|c|c|c|}
\hline Data & Identificação & Descrição \\
\hline $12 / 02 / 2016$ & $19 / 16$ & $\begin{array}{l}\text { Aprova o parecer técnico sobre o EIA/RIMA das "Obras de Aproveitamento } \\
\text { da Bacia do Rio Itapanhaú para Abastecimento da RMSP". }\end{array}$ \\
\hline $17 / 03 / 2016$ & $20 / 16$ & $\begin{array}{l}\text { Aprova critérios para análise e hierarquização de empreendimentos para } \\
\text { indicações ao FEHIDRO e estabelece o calendário do processo de } 2016 \text {. }\end{array}$ \\
\hline $20 / 05 / 2016$ & $21 / 16$ & Cria a Câmara Técnica Educação Ambiental - CTEA. \\
\hline $20 / 05 / 2016$ & $22 / 16$ & $\begin{array}{l}\text { Aprova critérios para seleção e indicação do Diretor Presidente da FABHAT, } \\
\text { constitui a Comissão do Processo Seletivo e dá outras providencias. }\end{array}$ \\
\hline 06/06/2016 & $23 / 16$ & $\begin{array}{l}\text { Aprova o Parecer Técnico sobre o EIA/RIMA da "Ampliação da Atividade de } \\
\text { Extração de Granito", no município de Caieiras. }\end{array}$ \\
\hline 06/06/2016 & $24 / 16$ & $\begin{array}{l}\text { Aprova o Parecer Técnico sobre a Compensação Ambiental referente ao } \\
\text { "Condomínio Village Dei Fiori", no município de Embu das Artes. }\end{array}$ \\
\hline $28 / 06 / 2016$ & $25 / 16$ & $\begin{array}{l}\text { Aprova a indicação de empreendimentos para financiamento com recursos do } \\
\text { FEHIDRO em } 2016 \text {, e dá outras providências. }\end{array}$ \\
\hline $28 / 06 / 2016$ & $26 / 16$ & $\begin{array}{l}\text { Aprova manifestação sobre a renovação da outorga do Sistema Cantareira em } \\
2016 .\end{array}$ \\
\hline 28/06/2016 & $27 / 16$ & $\begin{array}{l}\text { Dispõe sobre avaliação dos empreendimentos FEHIDRO indicados pelo CBH- } \\
\text { AT, constantes nos anexos I e II da Deliberação COFEHIDRO n }{ }^{\circ} 168 / 2016 \text {. }\end{array}$ \\
\hline $26 / 08 / 2016$ & $28 / 16$ & $\begin{array}{l}\text { Aprova o Regulamento do Processo Eleitoral das entidades da Sociedade Civil } \\
\text { para o mandato 2017-2019. }\end{array}$ \\
\hline $26 / 10 / 2016$ & $29 / 16$ & $\begin{array}{l}\text { Aprova a proposta de Anteprojeto de Lei Específica que cria a Área de } \\
\text { Proteção e Recuperação dos Mananciais do Alto Cotia - APRM-AC. }\end{array}$ \\
\hline $26 / 10 / 2016$ & $30 / 16$ & $\begin{array}{l}\text { Altera a Deliberação CBH-AT } \text { n }^{\circ} 22 \text {, de } 20 \text { de maio de } 2016 \text {, que aprovou os } \\
\text { critérios para seleção e indicação do Diretor Presidente da FABHAT e } \\
\text { constituiu a CPS. }\end{array}$ \\
\hline $30 / 11 / 2016$ & $31 / 16$ & $\begin{array}{l}\text { Aprova o Relatório I do Plano da Bacia da UGRHI-06 de 2016, contendo o } \\
\text { Relatório de Situação dos Recursos Hídricos da Bacia Hidrográfica do Alto } \\
\text { Tietê } 2016 \text {, ano base } 2015 \text {. }\end{array}$ \\
\hline $30 / 11 / 2016$ & $32 / 16$ & $\begin{array}{l}\text { Aprova critérios para análise e hierarquização de empreendimentos para } \\
\text { indicação ao FEHIDRO em 2017, e dá outras providências. }\end{array}$ \\
\hline $30 / 11 / 2016$ & $33 / 16$ & $\begin{array}{l}\text { Aprova o Parecer Técnico sobre a Compensação Ambiental referente ao } \\
\text { Conjunto Residencial Bosque do Cipó } 1 \text {, em Embu-Guaçu. }\end{array}$ \\
\hline $30 / 11 / 2016$ & $34 / 16$ & $\begin{array}{l}\text { Aprova o plano de trabalho, as premissas e a proposta orçamentária anual da } \\
\text { Fundação Agência da Bacia Hidrográfica do Alto Tietê para o exercício 2017, } \\
\text { e dá outras providências. }\end{array}$ \\
\hline $12 / 12 / 2016$ & $35 / 16$ & $\begin{array}{l}\text { Aprova a indicação do Diretor Presidente da Fundação Agência da Bacia } \\
\text { Hidrográfica do Alto Tietê. }\end{array}$ \\
\hline
\end{tabular}

Fonte: FEHIDRO, 2017, compilado pela autora. 


\section{ANEXO C - Síntese de projetos aprovados para recebimento de recursos}

financeiros do FEHIDRO

Quadro 1 - Projetos aprovados que constam em deliberação do ano 1996.

\begin{tabular}{|c|c|l|l|l|c|}
\hline $\begin{array}{c}\text { Data } \\
\text { deliberação }\end{array}$ & Código & \multicolumn{1}{|c|}{ Nome do empreendimento } & Situação & $\begin{array}{c}\text { Valor } \\
\text { pleiteado }\end{array}$ & Valor total \\
\hline $11 / 11 / 1996$ & AT-72 & $\begin{array}{l}\text { Educação ambiental e mobilização para } \\
\text { criação de subcomitês }\end{array}$ & Concluído & $\mathrm{R} \$ 200.000,00$ & $\mathrm{R} \$ 313.000,00$ \\
\hline $11 / 11 / 1996$ & AT-94 & $\begin{array}{l}\text { Programa socioambiental de coleta } \\
\text { seletiva de resíduos sólidos }\end{array}$ & Concluído & $\mathrm{R} \$ 150.000,00$ & $\mathrm{R} \$ 187.500,00$ \\
\hline $11 / 11 / 1996$ & AT-124 & $\begin{array}{l}\text { Projeto de educação ambiental com } \\
\text { mobilização social para a bacia do } \\
\text { reservatório Billings }\end{array}$ & Concluído & $\mathrm{R} \$ 40.000,00$ & $\mathrm{R} \$ 50.000,00$ \\
\hline $11 / 11 / 1996$ & AT-126 & $\begin{array}{l}\text { Sistema de informação em saúde e meio } \\
\text { ambiente }\end{array}$ & Cancelado & $\mathrm{R} \$ 70.000,00$ & $\mathrm{R} \$ 548.256,00$ \\
\hline $11 / 11 / 1996$ & AT-133 & $\begin{array}{l}\text { Projeto - Plano de usos integrados e } \\
\text { disciplinados das áreas marginais ao } \\
\text { reservatório da barragem Paiva Castro }\end{array}$ & Concluído & $\mathrm{R} \$ 300.000,00$ & $\mathrm{R} \$ 375.000,00$ \\
\hline $11 / 11 / 1996$ & AT-144 & $\begin{array}{l}\text { Programa socioambiental de coleta } \\
\text { seletiva de resíduos sólidos }\end{array}$ & Concluído & $\mathrm{R} \$ 148.977,09$ & $\mathrm{R} \$ 192.952,77$ \\
\hline $11 / 11 / 1996$ & AT-160 & $\begin{array}{l}\text { Plano uso integrado e disciplinado nas } \\
\text { áreas res. Paiva Castro }\end{array}$ & Cancelado & $\mathrm{R} \$ 300.000,00$ & $\mathrm{R} \$ 300.000,00$ \\
\hline
\end{tabular}

Fonte: FEHIDRO, 2017, compilado pela autora. 


\section{ANEXO C - Síntese de projetos aprovados para recebimento de recursos financeiros do FEHIDRO}

Quadro 2 - Projetos aprovados que constam em deliberação do ano 1997.

\begin{tabular}{|c|c|c|c|c|c|}
\hline $\begin{array}{c}\text { Data } \\
\text { deliberação }\end{array}$ & Código & Nome do empreendimento & Situação & $\begin{array}{c}\text { Valor } \\
\text { pleiteado }\end{array}$ & Valor total \\
\hline $05 / 09 / 1997$ & AT-80 & $\begin{array}{l}\text { Proteção de áreas de várzea da bacia do } \\
\text { Guarapiranga }\end{array}$ & Concluído & $\mathrm{R} \$ 36.000,00$ & $\mathrm{R} \$ 45.000,00$ \\
\hline 05/09/1997 & AT-81 & $\begin{array}{l}\text { Montagem banco de dados especiais } \\
\text { sobre recursos hídricos da Bacia Alto } \\
\text { Tietê }\end{array}$ & Concluído & $\mathrm{R} \$ 91.952,80$ & $\mathrm{R} \$ 117.470,60$ \\
\hline 05/09/1997 & AT-86 & $\begin{array}{ll}\text { Diagnóstico } & \text { socioambiental } \\
\text { participativo da bacia hidrográfica da } \\
\text { Billings }\end{array}$ & Concluído & 00,00 & 00 \\
\hline 05/09/1997 & AT-88 & \begin{tabular}{|l|l|}
$\begin{array}{l}\text { Projeto integrado de educação e } \\
\text { saneamento ambiental }\end{array}$ \\
\end{tabular} & Con & 00 & 00 \\
\hline 05/09/1997 & AT-108 & $\begin{array}{l}\text { Educação ambiental em sub-bacias do } \\
\text { Pirajussara }\end{array}$ & Cancelado & $\mathrm{R} \$ 46.766,41$ & $\mathrm{R} \$ 58.458,02$ \\
\hline 05/09/1997 & -109 & Prevenção e defesa contra enchentes & lído & $\mathrm{R} \$ 100.000,00$ & 0,00 \\
\hline $05 / 09 / 1997$ & AT-118 & $\begin{array}{|llll|}\text { Projeto diagnóstico } & \text { ambiental } & \text { e } \\
\text { recomendações para recuperação e } & \text { recuça } \\
\text { exploração do ecoturismo rio São } \\
\text { Lourenço }\end{array}$ & Cancelado & $\mathrm{R} \$ 20.521,18$ & 73,18 \\
\hline 05/09/1997 & AT-119 & $\begin{array}{l}\text { Ação de fiscalização integrada da área } \\
\text { de proteção da várzea do Tietê }\end{array}$ & Concluído & 00,00 & 00,00 \\
\hline 05/09/1997 & AT-120 & $\begin{array}{l}\text { Cadastro de irrigantes na bacia do Alto } \\
\text { Tietê }\end{array}$ & Concluído & $\mathrm{R} \$ 162.500,00$ & $\mathrm{R} \$ 203.125,00$ \\
\hline 05/09/1997 & AT-122 & $\begin{array}{|lllll|}\begin{array}{l}\text { Diagnóstico } \\
\text { ambiental }\end{array} & \text { e sistema de gestão } \\
\end{array}$ & Concluído & $\mathrm{R} \$ 130.000,00$ & $\mathrm{R} \$ 170.000,00$ \\
\hline 05/09/1997 & AT-123 & $\begin{array}{l}\text { Estudo da potencialidade de turismo e } \\
\text { lazer na área do município de Mairiporã }\end{array}$ & Concluído & 0,00 & $\mathrm{R} \$ 120.000,00$ \\
\hline $05 / 09 / 1$ & AT-127 & $\begin{array}{l}\text { Diagnóstico de resíduos e elaboração de } \\
\text { programa de educação ambiental em } \\
\text { área de proteção de mananciais }\end{array}$ & í́do & 0,00 & $\mathrm{R} \$$ \\
\hline 05/09/1997 & AT-134 & $\begin{array}{l}\text { Conexão: estabelecendo correntes } \\
\text { cidadania pela defesa dos mananciais }\end{array}$ & Concluído & $\mathrm{R} \$ 169.460,00$ & $\mathrm{R} \$ 216.740,00$ \\
\hline 05/09/1997 & AT-138 & Projeto Chão Verde - Terra Firme & Concluído & $\mathrm{R} \$ 80.000,00$ & $\mathrm{R} \$ 102.303,97$ \\
\hline 05/09/1997 & AT-140 & \begin{tabular}{|l|l|} 
Caracterização & socioeconômica dos \\
pescadores profissionais da Billings
\end{tabular} & Concluído & $\mathrm{R} \$ 38.599,26$ & $\mathrm{R} \$ 48.370,00$ \\
\hline 05/09/1997 & AT-143 & $\begin{array}{l}\text { Construção de escadarias hidráulicas e } \\
\text { drenagem em vielas }\end{array}$ & Concluído & $\mathrm{R} \$ 118.600,00$ & $\mathrm{R} \$ 148.464,14$ \\
\hline 05/09/1997 & AT-146 & \begin{tabular}{|l} 
Subsídios do meio físico para \\
planejamento do desenvolvimento da \\
irrigação na bacia do Alto Tietê
\end{tabular} & Concluído & $\mathrm{R} \$ 119.878,71$ & $\mathrm{R} \$ 149.848,39$ \\
\hline 05/09/1997 & AT-161 & Parque do Nirvana & Concluído & $\mathrm{R} \$ 204.577,58$ & $\mathrm{R} \$ 245.555,16$ \\
\hline
\end{tabular}

Fonte: FEHIDRO, 2017, compilado pela autora. 


\section{ANEXO C - Síntese de projetos aprovados para recebimento de recursos financeiros do FEHIDRO}

Quadro 3 - Projetos aprovados que constam em deliberação do ano 1998.

\begin{tabular}{|c|c|c|c|c|c|}
\hline $\begin{array}{c}\text { Data } \\
\text { deliberação }\end{array}$ & Código & Nome do empreendimento & Situação & $\begin{array}{c}\text { Valor } \\
\text { pleiteado }\end{array}$ & Valor total \\
\hline $02 / 12 / 1998$ & AT-56 & Reviver o verde & Concluído & $\mathrm{R} \$ 80.000,00$ & $\$ 100.000,00$ \\
\hline $02 / 12 / 1998$ & AT-73 & \begin{tabular}{|c|}
$\begin{array}{c}\text { Diagnóstico limnológico e levantamento } \\
\text { ictiofanístico da represa Ponte Nova }\end{array}$ \\
\end{tabular} & Concluído & $\mathrm{R} \$ 98.000,00$ & $\mathrm{R} \$ 268.280,00$ \\
\hline 08/06/1998 & AT-74 & Projeto de educação ambiental & Concluído & $\mathrm{R} \$ 12.500,00$ & $\mathrm{R} \$ 15.625,00$ \\
\hline 08/06/1998 & AT-76 & $\begin{array}{c}\text { Elaboração do Plano de Investimento } \\
\text { em Recursos Hídricos para a bacia } \\
\text { hidrográfica do Alto Tietê }\end{array}$ & Concluído & $\mathrm{R} \$ 900.000,00$ & $\begin{array}{c}\mathrm{R} \$ \\
1.125 .940,00\end{array}$ \\
\hline $02 / 12 / 1998$ & AT-83 & $\begin{array}{c}\begin{array}{c}\text { Programa socioambiental de capacitação } \\
\text { e atuação para proteção/conservação de } \\
\text { Embu e região }\end{array} \\
\end{array}$ & Concluído & $\mathrm{R} \$ 78.636,25$ & $\mathrm{R} \$ 103.402,25$ \\
\hline 08/06/1998 & AT-84 & Programa de educação ambiental & Concluído & $\mathrm{R} \$ 74.955,00$ & $\mathrm{R} \$ 110.444,00$ \\
\hline 08/06/1998 & AT-85 & $\begin{array}{c}\text { Programa ecomunidade de educação } \\
\text { ambiental }\end{array}$ & Concluído & $\mathrm{R} \$ 93.810,00$ & $\mathrm{R} \$ 118.184,00$ \\
\hline $02 / 12 / 1998$ & AT-90 & $\begin{array}{r}\text { Parque Municipal n } \\
\text { Tietê, na área }\end{array}$ & Concluído & $\mathrm{R} \$ 80.000,00$ & $\mathrm{R} \$ 100.000,00$ \\
\hline 08/06/1998 & AT-91 & $\begin{array}{r}\text { Programa de in } \\
\text { APRI } \\
\end{array}$ & Concluído & $\mathrm{R} \$ 57.751,20$ & $\mathrm{R} \$ 72.188,20$ \\
\hline 08/06/1998 & AT-93 & \begin{tabular}{|c|}
$\begin{array}{c}\text { Educação ambiental para a conservação } \\
\text { da biodiversidade do Alto Tietê }\end{array}$ \\
\end{tabular} & $\begin{array}{c}\text { Em } \\
\text { xecução }\end{array}$ & $\mathrm{R} \$ 22.392,00$ & $\mathrm{R} \$ 27.990,00$ \\
\hline $02 / 12 / 1998$ & AT-96 & Vizinhança verde - fase II & Cancelado & $\mathrm{R} \$ 79.200,00$ & $\mathrm{R} \$ 129.200,00$ \\
\hline 08/06/1998 & AT-97 & $\begin{array}{l}\text { Comportam } g \\
\text { pesados na bc }\end{array}$ & Concluído & $\mathrm{R} \$ 44.000,00$ & $.000,00$ \\
\hline $02 / 12 / 1998$ & AT-98 & $\begin{array}{c}\text { Educação ambiental na região do } \\
\text { manancial da Guarapiranga }\end{array}$ & Concluído & $\mathrm{R} \$ 63.425,00$ & $\mathrm{R} \$ 113.825,00$ \\
\hline 08/06/1998 & AT-99 & $\begin{array}{r}\text { Recuperação e pı } \\
\text { Taia } \\
\end{array}$ & Cancelado & $\mathrm{R} \$ 34.400,00$ & $\mathrm{R} \$ 61.351,56$ \\
\hline 29/09/1998 & $\Gamma-100$ & Oficina de educação ambiental & Concluído & $\mathrm{R} \$ 58.415,00$ & $2 \$ 75.385,00$ \\
\hline $02 / 12 / 1998$ & AT-102 & \begin{tabular}{|c|} 
Implantação de modelo matemático de \\
qualidade de água - reservatório Billings
\end{tabular} & Concluído & $\mathrm{R} \$ 138.000,00$ & $\mathrm{R} \$ 172.500,00$ \\
\hline 08/06/1998 & AT-103 & Coleta de lixo - aquisição de veículo & Concluído & $\mathrm{R} \$ 12.500,00$ & $\$ 15.625,00$ \\
\hline 08/06/1998 & AT-106 & Agenda 21 das águas & Cancelado & $\mathrm{R} \$ 60.000,00$ & $\mathrm{R} \$ 75.000,00$ \\
\hline 29/09/1998 & AT-107 & $\begin{array}{l}\text { Avivamento de divisas do Parque } \\
\text { Estadual do Juquery - O nascimento de } \\
\text { um parque }\end{array}$ & Cancelado & $\mathrm{R} \$ 209.561,00$ & $\mathrm{R} \$ 330.561,00$ \\
\hline $02 / 12 / 1998$ & AT-110 & \begin{tabular}{|l|} 
Formação de agentes multiplicadores do \\
processo de monitoramento \\
participativo na bacia Guarapiranga \\
\end{tabular} & Concluído & $\mathrm{R} \$ 12.040,00$ & $\mathrm{R} \$ 15.050,00$ \\
\hline 08/06/1998 & AT-112 & $\begin{array}{l}\text { Capacitação para o monitoramento e } \\
\text { gerenciamento do sistema produtor do } \\
\text { Alto Tietê }\end{array}$ & Cancelado & $\mathrm{R} \$ 124.000,00$ & $\mathrm{R} \$ 155.000,00$ \\
\hline $08 /$ & AT-113 & \begin{tabular}{|l|}
$\begin{array}{l}\text { Programa de educação ambiental e } \\
\text { cidadania de Embu }\end{array}$ \\
\end{tabular} & uído & 0,00 & 77,50 \\
\hline $02 / 12 / 1998$ & AT-115 & $\begin{array}{l}\text { Programa de prevenção e defesa contra } \\
\text { inundações - segunda etapa }\end{array}$ & Concluído & $\mathrm{R} \$ 200.000,00$ & $\mathrm{R} \$ 250.000,00$ \\
\hline 08/06/1998 & AT-116 & $\begin{array}{l}\text { Programa de prevenção e defesa contra } \\
\text { inundações - primeira etapa }\end{array}$ & Concluído & $\mathrm{R} \$ 175.000,00$ & $\mathrm{R} \$ 218.802,00$ \\
\hline 08/06/1998 & AT-117 & Execução de projeto de lixo e cidadania & Concluído & $\mathrm{R} \$ 29.200,00$ & $\mathrm{R} \$ 36.500,00$ \\
\hline
\end{tabular}




\section{ANEXO C - Síntese de projetos aprovados para recebimento de recursos financeiros do FEHIDRO}

Quadro 3 - Projetos aprovados que constam em deliberação do ano 1998.

Continua

\begin{tabular}{|c|c|c|c|c|c|}
\hline $\begin{array}{c}\text { Data } \\
\text { deliberação }\end{array}$ & Código & Nome do empreendimento & Situação & $\begin{array}{c}\text { Valor } \\
\text { pleiteado }\end{array}$ & Valor total \\
\hline 29/09/1998 & AT-121 & $\begin{array}{l}\text { Consultoria técnica para a elaboração de } \\
\text { minuta de Lei Específica da APRM } \\
\text { Billings e PDPA }\end{array}$ & Concluído & $\mathrm{R} \$ 120.000,00$ & $\mathrm{R} \$ 150.000,00$ \\
\hline 02/12/1998 & AT-125 & $\begin{array}{l}\text { Projeto integrado de educação ambiental } \\
\text { e recomposição vegetal }\end{array}$ & Cancelado & $\mathrm{R} \$ 74.270,00$ & $\mathrm{R} \$ 107.275,30$ \\
\hline 02/12/1998 & AT-128 & Projeto a arte e o meio ambiente & Concluído & $\mathrm{R} \$ 12.000,00$ & $\mathrm{R} \$ 15.600,00$ \\
\hline 08/06/1998 & AT-129 & \begin{tabular}{|l} 
Educação ambiental na região de \\
mananciais da represa Guarapiranga
\end{tabular} & Concluído & $\mathrm{R} \$ 27.500,00$ & $\mathrm{R} \$ 94.700,00$ \\
\hline 08/06/1998 & AT-130 & $\begin{array}{l}\text { Descobrindo a Guarapiranga - } \\
\text { consciência ambiental }\end{array}$ & Concluído & $\mathrm{R} \$ 51.550,00$ & $\mathrm{R} \$ 64.500,00$ \\
\hline 08/06/1998 & AT-131 & $\begin{array}{l}\text { Capitação técnica e educação ambiental } \\
\text { de lideranças organizações da sociedade } \\
\text { civil }\end{array}$ & Concluído & $\mathrm{R} \$ 34.350,00$ & $\mathrm{R} \$ 42.937,50$ \\
\hline 08/06/1998 & AT-132 & $\begin{array}{l}\text { Monitoramento ambiental participativo } \\
\text { na bacia do Guarapiranga }\end{array}$ & Concluído & $\mathrm{R} \$ 27.500,00$ & $\mathrm{R} \$ 34.375,04$ \\
\hline 08/06/1998 & AT-135 & $\begin{array}{l}\text { Educação ambiental com mobilidade } \\
\text { social na bacia do reservatório Billings }\end{array}$ & Concluído & $\mathrm{R} \$ 72.351,20$ & $\mathrm{R} \$ 90.061,44$ \\
\hline 08/06/1998 & AT-136 & $\begin{array}{l}\text { Projeto integrado de educação e } \\
\text { saneamento ambiental II }\end{array}$ & Cancelado & $\mathrm{R} \$ 48.900,00$ & $\mathrm{R} \$ 67.846,00$ \\
\hline 08/06/1998 & AT-137 & $\begin{array}{l}\text { Meio ambiente e trabalho do servidor } \\
\text { público municipal }\end{array}$ & Cancelado & $\mathrm{R} \$ 12.500,00$ & $\mathrm{R} \$ 15.650,00$ \\
\hline 08/06/1998 & AT-139 & $\begin{array}{l}\text { Núcleo Águas Claras - educação } \\
\text { ambiental }\end{array}$ & Concluído & $\mathrm{R} \$ 109.419,00$ & $\mathrm{R} \$ 136.774,00$ \\
\hline 08/06/1998 & AT-142 & $\begin{array}{l}\text { Contenção de encosta - prevenção de } \\
\text { erosão }\end{array}$ & Concluído & $\mathrm{R} \$ 181.496,72$ & $\mathrm{R} \$ 226.870,90$ \\
\hline 08/06/1998 & AT-145 & $\begin{array}{l}\text { Viveiro de mudas e fomento da } \\
\text { vegetação - Billings Margem Verde }\end{array}$ & Concluído & $\mathrm{R} \$ 59.751,20$ & $\mathrm{R} \$ 88.426,22$ \\
\hline 02/12/1998 & AT-148 & Lagoa do Bacuri & Concluído & $\mathrm{R} \$ 60.000,00$ & $\mathrm{R} \$ 84.322,80$ \\
\hline 20/09/1998 & AT-150 & $\begin{array}{l}\text { Educação ambiental na gestão de bacias } \\
\text { hidrográficas do Estado de São Paulo }\end{array}$ & Cancelado & $\mathrm{R} \$ 30.130,00$ & $\mathrm{R} \$ 37.662,50$ \\
\hline 08/06/1998 & AT-153 & $\begin{array}{l}\text { Atlas temático da sub-região Tietê- } \\
\text { Cabeceiras }\end{array}$ & Concluído & $\mathrm{R} \$ 49.200,00$ & $\mathrm{R} \$ 131.650,00$ \\
\hline 02/12/1998 & AT-154 & $\begin{array}{l}\text { Recuperação ambiental } \\
\text { degradadas da GSP } \\
\text { Pinheiros Pirapora }\end{array}$ & Concluído & $\mathrm{R} \$ 48.000,00$ & $\mathrm{R} \$ 303.606,96$ \\
\hline 29/09/1998 & AT-155 & $\begin{array}{l}\text { Semana da Cantareira }- \text { projeto de } \\
\text { difusão de informações e tecnologias } \\
\text { sobre o uso da água }\end{array}$ & Concluído & $\mathrm{R} \$ 83.296,86$ & $\mathrm{R} \$ 107.148,01$ \\
\hline 02/12/1998 & AT-159 & $\begin{array}{l}\text { Implantação de modelo matemático de } \\
\text { qualidade de água - reservatório Billings }\end{array}$ & Cancelado & $\mathrm{R} \$ 138.000,00$ & $\mathrm{R} \$ 172.500,00$ \\
\hline 29/09/1998 & AT-166 & Reciclarte - coleta de resíduos sólidos & Concluído & $\mathrm{R} \$ 48.185,14$ & $\mathrm{R} \$ 60.234,14$ \\
\hline 29/09/1998 & AT-196 & $\begin{array}{l}\text { Fomento à fiscalização integrada - } \\
\text { Tamanduateí-Billings }\end{array}$ & Cancelado & $\mathrm{R} \$ 52.370,00$ & $\mathrm{R} \$ 65.462,50$ \\
\hline
\end{tabular}

Fonte: FEHIDRO, 2017, compilado pela autora. 


\section{ANEXO C - Síntese de projetos aprovados para recebimento de recursos financeiros do FEHIDRO}

Quadro 4 - Projetos aprovados que constam em deliberação do ano 1999.

\begin{tabular}{|c|c|c|c|c|c|}
\hline $\begin{array}{c}\text { Data } \\
\text { deliberação }\end{array}$ & Código & Nome do empreendimento & Situação & $\begin{array}{c}\text { Valor } \\
\text { pleiteado }\end{array}$ & Valor total \\
\hline $23 / 08 / 1999$ & AT-52 & Construindo o futuro da Guarapiranga & Concluído & $\mathrm{R} \$ 21.800,00$ & $\mathrm{R} \$ 27.250,00$ \\
\hline $23 / 08 / 1999$ & AT-78 & $\begin{array}{l}\text { Projeto de reciclagem de lodos das } \\
\text { estações de água da RMSP }\end{array}$ & Concluído & $\mathrm{R} \$ 81.986,00$ & $\mathrm{R} \$ 103.545,32$ \\
\hline $23 / 08 / 1999$ & AT-79 & $\begin{array}{l}\text { Centro de educação e difusão de } \\
\text { tecnologias ambientais para conservação } \\
\text { de ecossistemas de várzeas da bacia } \\
\text { Alto Tietê }\end{array}$ & Concluído & $\mathrm{R} \$ 80.000,00$ & $\mathrm{R} \$ 100.000,00$ \\
\hline 23/09/1999 & AT-82 & $\begin{array}{l}\text { Sistema de diagnóstico e avaliação de } \\
\text { projetos do Alto Tietê }\end{array}$ & Concluído & $\mathrm{R} \$ 79.000,00$ & $\mathrm{R} \$ 98.750,00$ \\
\hline 23/08/1999 & AT-87 & $\begin{array}{l}\text { Estudo da disposição de contaminantes } \\
\text { em sedimentos da represa Billings }\end{array}$ & Concluído & $\mathrm{R} \$ 59.530,00$ & $\mathrm{R} \$ 74.412,50$ \\
\hline $23 / 08 / 1999$ & AT-89 & $\begin{array}{l}\text { Erosão da bacia do Alto Tietê: avaliação } \\
\text { e diretrizes para conservação de } \\
\text { recursos hídricos superficiais }\end{array}$ & Concluído & $\mathrm{R} \$ 112.364,00$ & $\mathrm{R} \$ 150.420,00$ \\
\hline $23 / 08 / 1999$ & AT-92 & $\begin{array}{l}\text { Educação com enfoque em tratamento } \\
\text { de esgotos na RMSP }\end{array}$ & Concluído & $\mathrm{R} \$ 120.000,00$ & 0,00 \\
\hline $23 / 08 / 1999$ & AT-95 & $\begin{array}{l}\text { Estrutura fundiária da área de proteção } \\
\text { dos mananciais da região sul }\end{array}$ & Cancelado & $\mathrm{R} \$ 40.770,00$ & $\mathrm{R} \$ 123.490,00$ \\
\hline 23/09/1999 & AT-104 & 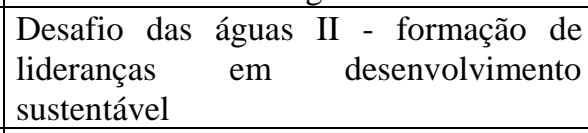 & Concluído & $\mathrm{R} \$ 68.000,00$ & $\mathrm{R} \$ 85.000,00$ \\
\hline 23/08/1999 & AT-105 & $\begin{array}{l}\text { Cyanophycea/ Cyanobactérias tóxicas } \\
\text { em reservatórios do Alto Tietê }\end{array}$ & Concluído & $\mathrm{R} \$ 36.000,00$ & $\mathrm{R} \$ 109.996,56$ \\
\hline $23 / 08 / 1999$ & AT-111 & Química, meio ambiente e sociedade & Concluído & $\mathrm{R} \$ 15.000,00$ & $\mathrm{R} \$ 37.357,00$ \\
\hline $23 / 08 / 1999$ & AT-114 & Chão Verde - Terra Firme - 2 & Concluído & $\mathrm{R} \$ 93.700,00$ & $\mathrm{R} \$ 117.660,00$ \\
\hline $23 / 08 / 1999$ & AT-141 & $\begin{array}{l}\text { Barragem de contenção das águas } \\
\text { pluviais no córrego Paim (terceira etapa) }\end{array}$ & Concluído & $\mathrm{R} \$ 130.000,00$ & $\mathrm{R} \$ 162.500,00$ \\
\hline $23 / 08 / 1999$ & AT-147 & $\begin{array}{l}\text { Projeto Billings potável por inteiro - } \\
\text { fase III - educação ambiental }\end{array}$ & Concluído & $\mathrm{R} \$ 70.000,00$ & $\mathrm{R} \$ 87.500,00$ \\
\hline $23 / 08 / 1999$ & AT-152 & $\begin{array}{l}\text { Campanha educacional para promover o } \\
\text { uso racional e economia da água }\end{array}$ & Concluído & $\mathrm{R} \$ 95.740,00$ & $\mathrm{R} \$ 128.740,00$ \\
\hline 23/08/1999 & AT-157 & $\begin{array}{l}\text { Seminário avaliação das áreas e ações } \\
\text { prioritárias para a recuperação, } \\
\text { conservação } \\
\text { mananciais }\end{array}$ & Concluído & $\mathrm{R} \$ 59.020,00$ & $\mathrm{R} \$ 89.896,10$ \\
\hline $23 / 08 / 1999$ & AT-158 & $\begin{array}{l}\text { Lama de luz e magia - educação } \\
\text { ambiental aoo longo do rio Tietê }\end{array}$ & Cancelado & $\mathrm{R} \$ 39.600,00$ & $\mathrm{R} \$ 49.500,00$ \\
\hline $23 / 09 / 1999$ & AT-162 & $\begin{array}{l}\text { Diagnóstico } \\
\text { participativo do Guarapiranga }\end{array}$ & Concluído & $\mathrm{R} \$ 58.574,00$ & $\mathrm{R} \$ 75.820,00$ \\
\hline $23 / 09 / 1999$ & AT-163 & $\begin{array}{l}\text { Projeto de educação ambiental para a } \\
\text { região do córrego Rico }\end{array}$ & Cancelado & $\mathrm{R} \$ 41.000,00$ & $\mathrm{R} \$ 51.250,00$ \\
\hline 23/09/1999 & AT-164 & $\begin{array}{l}\text { Diagnóstico socioambiental } \\
\text { participativo da Cantareira }\end{array}$ & Concluído & $\mathrm{R} \$ 108.000,00$ & $\mathrm{R} \$ 135.000,00$ \\
\hline
\end{tabular}

Fonte: FEHIDRO, 2017, compilado pela autora. 


\section{ANEXO C - Síntese de projetos aprovados para recebimento de recursos financeiros do FEHIDRO}

Quadro 5 - Projetos aprovados que constam em deliberação do ano 2000.

\begin{tabular}{|c|c|c|c|c|c|}
\hline $\begin{array}{c}\text { Data } \\
\text { deliberação }\end{array}$ & Código & Nome do empreendimento & Situação & $\begin{array}{c}\text { Valor } \\
\text { pleiteado }\end{array}$ & Valor total \\
\hline $14 / 12 / 2000$ & AT-58 & $\begin{array}{l}\text { Educação ambiental para favela } \\
\text { Heliópolis com enfoque em esgotos e } \\
\text { lixo }\end{array}$ & Cancelado & $\mathrm{R} \$ 67.400,00$ & $\mathrm{R} \$ 84.250,00$ \\
\hline $14 / 12 / 2000$ & AT-61 & $\begin{array}{llll}\text { Projeto } & \text { Tabarana: } & \text { conservação/ } \\
\text { diversidade de peixes } & \text { e educação } \\
\text { ambiental APA } & & & \\
\end{array}$ & Cancelado & $\mathrm{R} \$ 110.510,00$ & $\mathrm{R} \$ 138.137,00$ \\
\hline $14 / 12 / 2000$ & AT-62 & $\begin{array}{l}\text { Desenvolvimento de métodos com alta } \\
\text { frequência analítica para monitor/... }\end{array}$ & Cancelado & $\mathrm{R} \$ 79.580,00$ & $\mathrm{R} \$ 121.580,00$ \\
\hline $14 / 12 / 2000$ & AT-67 & Lagoa do Bacuri - segunda fase & Cancelado & $\mathrm{R} \$ 8.000,00$ & $\mathrm{R} \$ 23.213,80$ \\
\hline $14 / 12 / 2000$ & AT-68 & $\begin{array}{l}\text { Plano desenvolvimento/ proteção } \\
\text { ambiental e minuta lei especial da } \\
\text { APRM-Cotia }\end{array}$ & Cancelado & $\mathrm{R} \$ 312.000,00$ & $\mathrm{R} \$ 390.000,00$ \\
\hline $14 / 12 / 2000$ & AT-75 & $\begin{array}{l}\text { Estudo hidráulico/hidrológico - modelo } \\
\text { hidrodinâmico da várzea do rio Tietê }\end{array}$ & Concluído & $\mathrm{R} \$ 300.000,00$ & $\mathrm{R} \$ 375.000,00$ \\
\hline $14 / 12 / 2000$ & AT-77 & $\begin{array}{l}\text { Elaboração de mapa de uso e ocupação } \\
\text { do solo da RMSP }\end{array}$ & Concluído & $\mathrm{R} \$ 249.999,14$ & $\mathrm{R} \$ 312.500,00$ \\
\hline $14 / 12 / 2000$ & AT-101 & $\begin{array}{l}\text { Dia mundial do meio ambiente: a água } \\
\text { na palavra da mulher }\end{array}$ & Concluído & $\mathrm{R} \$ 154.500,00$ & $\mathrm{R} \$ 193.125,00$ \\
\hline $14 / 12 / 2000$ & AT-165 & Formação de agentes multiplicadores II & Concluído & $\mathrm{R} \$ 9.480,00$ & $\mathrm{R} \$ 11.850,00$ \\
\hline $14 / 12 / 2000$ & AT-204 & $\begin{array}{l}\text { Plano Diretor Regional da sub-região } \\
\text { Juqueri-Cantareira da UGRHI Alto } \\
\text { Tietê }\end{array}$ & Concluído & $\mathrm{R} \$ 320.000,00$ & $\mathrm{R} \$ 320.000,00$ \\
\hline
\end{tabular}

Fonte: FEHIDRO, 2017, compilado pela autora. 


\section{ANEXO C - Síntese de projetos aprovados para recebimento de recursos financeiros do FEHIDRO}

Quadro 6 - Projetos aprovados que constam em deliberação do ano 2002.

\begin{tabular}{|c|c|c|c|c|c|}
\hline $\begin{array}{c}\text { Data } \\
\text { deliberação }\end{array}$ & Código & Nome do empreendimento & Situação & $\begin{array}{c}\text { Valor } \\
\text { pleiteado }\end{array}$ & Valor total \\
\hline $19 / 04 / 2002$ & AT-48 & $\begin{array}{l}\text { Plano Diretor Regional da sub-região } \\
\text { Pinheiros-Pirapora }\end{array}$ & Concluído & $\mathrm{R} \$ 320.000,00$ & $\mathrm{R} \$ 400.000,00$ \\
\hline $19 / 04 / 2002$ & AT-149 & $\begin{array}{l}\text { Implantação do programa municipal de } \\
\text { coleta seletiva e reciclagem do lixo }\end{array}$ & Cancelado & $\mathrm{R} \$ 70.000,00$ & $\mathrm{R} \$ 127.585,15$ \\
\hline $19 / 04 / 2002$ & AT-151 & Saneamento municipal de Salesópolis & Cancelado & $\mathrm{R} \$ 78.201,20$ & $\mathrm{R} \$ 97.751,50$ \\
\hline $19 / 04 / 2002$ & AT-156 & Drenagem de estradas rurais - zona rural & Cancelado & $\mathrm{R} \$ 87.890,00$ & $\mathrm{R} \$ 111.159,60$ \\
\hline $19 / 04 / 2002$ & AT-167 & Projeto mídia ambiente & Concluído & $\mathrm{R} \$ 98.000,00$ & $\mathrm{R} \$ 122.500,00$ \\
\hline $19 / 04 / 2002$ & AT-197 & $\begin{array}{l}\text { Programa de educação ambiental - } \\
\text { SABESP educando para a cidadania - } \\
\text { Billings }\end{array}$ & Concluído & $\mathrm{R} \$ 57.700,00$ & $\mathrm{R} \$ 83.500,00$ \\
\hline $19 / 04 / 2002$ & AT-198 & $\begin{array}{l}\text { Programa de educação ambiental - } \\
\text { SABESP educando para a cidadania - } \\
\text { Billings }\end{array}$ & Concluído & $\mathrm{R} \$ 70.000,00$ & $\mathrm{R} \$ 100.000,00$ \\
\hline
\end{tabular}

Fonte: FEHIDRO, 2017, compilado pela autora. 


\section{ANEXO C - Síntese de projetos aprovados para recebimento de recursos financeiros do FEHIDRO}

Quadro 7 - Projetos aprovados que constam em deliberação do ano 2003.

\begin{tabular}{|c|c|c|c|c|c|}
\hline $\begin{array}{c}\text { Data } \\
\text { deliberação }\end{array}$ & Código & Nome do empreendimento & Situação & $\begin{array}{c}\text { Valor } \\
\text { pleiteado }\end{array}$ & Valor total \\
\hline $30 / 06 / 2003$ & AT-69 & $\begin{array}{l}\text { Intervenção tecnológica do uso racional } \\
\text { da água para redução de perdas em } \\
\text { escolas estaduais da RMSP }\end{array}$ & Concluído & $\mathrm{R} \$ 600.000,00$ & $\mathrm{R} \$ 750.000,00$ \\
\hline $30 / 06 / 2003$ & AT-170 & $\begin{array}{l}\text { Projeto de adequação da área do antigo } \\
\text { vazadouro municipal de resíduos a céu } \\
\text { aberto }\end{array}$ & Concluído & $\mathrm{R} \$ 84.050,00$ & $\mathrm{R} \$ 107.150,00$ \\
\hline $30 / 06 / 2003$ & AT-172 & Chão Verde - Terra Firme - 3 & Concluído & $\mathrm{R} \$ 110.117,55$ & $\mathrm{R} \$ 139.389,30$ \\
\hline $30 / 06 / 2003$ & AT-173 & Estrada Parque Serra da Cantareira & Concluído & $\mathrm{R} \$ 152.549,00$ & $\mathrm{R} \$ 193.100,00$ \\
\hline $30 / 06 / 2003$ & AT-174 & Patrulha especial de proteção ambiental & Concluído & $\mathrm{R} \$ 134.436,00$ & $\mathrm{R} \$ 197.700,00$ \\
\hline $30 / 06 / 2003$ & AT-175 & \begin{tabular}{|l}
$\begin{array}{l}\text { Ensino sistematizado de proteção à } \\
\text { natureza }\end{array}$ \\
\end{tabular} & Concluído & $\mathrm{R} \$ 81.732,00$ & $\mathrm{R} \$ 136.220,00$ \\
\hline $30 / 06 / 2003$ & AT-176 & O rio pelos trilhos & Concluído & $\mathrm{R} \$ 97.841,35$ & $\mathrm{R} \$ 123.849,80$ \\
\hline $30 / 06 / 2003$ & AT-178 & $\begin{array}{l}\text { Projeto nascente - fortalecimento da } \\
\text { educação ambiental na nascente do } \\
\text { Tietê }\end{array}$ & Concluído & $\mathrm{R} \$ 64.993,00$ & $\mathrm{R} \$ 81.241,25$ \\
\hline $30 / 06 / 2003$ & AT-180 & $\begin{array}{l}\text { Ensino sistematizado de proteção à } \\
\text { natureza }\end{array}$ & Concluído & $\mathrm{R} \$ 80.000,00$ & $\mathrm{R} \$ 100.000,00$ \\
\hline $30 / 06 / 2003$ & AT-182 & $\begin{array}{l}\text { Projeto de proteção integrada na área do } \\
\text { subcomitê Cotia-Guarapiranga }\end{array}$ & Concluído & $\mathrm{R} \$ 84.100,00$ & $\mathrm{R} \$ 105.125,00$ \\
\hline $30 / 06 / 2003$ & AT-183 & \begin{tabular}{|l} 
Projeto de fiscalização e educação \\
ambiental
\end{tabular} & Concluído & $\mathrm{R} \$ 60.000,00$ & $\mathrm{R} \$ 75.000,00$ \\
\hline $30 / 06 / 2003$ & AT-184 & $\begin{array}{l}\text { Construção de centro de triagem de } \\
\text { resíduos sólidos }\end{array}$ & Concluído & $\mathrm{R} \$ 179.516,97$ & $\mathrm{R} \$ 224.396,21$ \\
\hline $30 / 06 / 2003$ & AT-186 & $\begin{array}{l}\text { Indicação de áreas de intervenção e das } \\
\text { estratégias e prioridades para ação na } \\
\text { bacia hidrográfica do reservatório } \\
\text { Billings }\end{array}$ & Concluído & $\mathrm{R} \$ 279.997,57$ & $\mathrm{R} \$ 349.996,96$ \\
\hline $30 / 06 / 2003$ & AT-187 & $\begin{array}{l}\text { Interpretação e análise do uso do solo } \\
\text { em } 2003 \text { na bacia hidrográfica Billings- } \\
\text { Tamanduateí }\end{array}$ & Cancelado & $\mathrm{R} \$ 40.000,00$ & $\mathrm{R} \$ 50.000,00$ \\
\hline $30 / 06 / 2003$ & AT-188 & $\begin{array}{l}\text { Ampliação do programa de educação } \\
\text { ambiental em área de proteção de } \\
\text { mananciais }\end{array}$ & Concluído & $\mathrm{R} \$ 55.920,00$ & $\mathrm{R} \$ 69.900,00$ \\
\hline $30 / 06 / 2003$ & AT-189 & Automação do aspersor sobre o rio Tietê & Concluído & $\mathrm{R} \$ 198.360,00$ & $\mathrm{R} \$ 247.950,00$ \\
\hline $30 / 06 / 2003$ & AT-191 & $\begin{array}{l}\text { Projeto de educação ambiental para a } \\
\text { rede municipal de ensino }\end{array}$ & Concluído & $\mathrm{R} \$ 70.000,00$ & $\mathrm{R} \$ 87.500,00$ \\
\hline $30 / 06 / 2003$ & AT-192 & Patrulha especial de proteção ambiental & Concluído & $\mathrm{R} \$ 110.000,00$ & $\mathrm{R} \$ 27.500,00$ \\
\hline $30 / 06 / 2003$ & AT-193 & 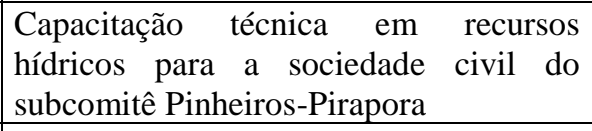 & Concluído & $\mathrm{R} \$ 45.000,00$ & $\mathrm{R} \$ 56.250,00$ \\
\hline $30 / 06 / 2003$ & AT-194 & Sementre de hoje, sombras do amanhã & Concluído & $\mathrm{R} \$ 156.640,00$ & $\mathrm{R} \$ 195.800,00$ \\
\hline $30 / 06 / 2003$ & AT-195 & $\begin{array}{l}\text { Ensino sistematizado de proteção à } \\
\text { natureza }\end{array}$ & Concluído & $\mathrm{R} \$ 60.000,00$ & $\mathrm{R} \$ 15.000,00$ \\
\hline $30 / 06 / 2003$ & AT-199 & $\begin{array}{l}\text { Sistema de previsão e modelagem de } \\
\text { vazões diárias para a bacia do Alto Tietê }\end{array}$ & Concluído & $\mathrm{R} \$ 320.000,00$ & $\mathrm{R} \$ 400.000,00$ \\
\hline $30 / 06 / 2003$ & AT-200 & $\begin{array}{l}\text { Cobrança pelo uso da água } \\
\text { levantamento do perfil dos usuários }\end{array}$ & Cancelado & $\mathrm{R} \$ 115.000,00$ & $\mathrm{R} \$ 143.750,00$ \\
\hline
\end{tabular}

Continua 


\begin{abstract}
ANEXO C - Síntese de projetos aprovados para recebimento de recursos financeiros do FEHIDRO
\end{abstract}

Quadro 7 - Projetos aprovados que constam em deliberação do ano 2003.

Continuação

\begin{tabular}{|c|c|l|l|c|c|}
\hline $\begin{array}{c}\text { Data } \\
\text { deliberação }\end{array}$ & Código & \multicolumn{1}{|c|}{ Nome do empreendimento } & Situação & $\begin{array}{c}\text { Valor } \\
\text { pleiteado }\end{array}$ & Valor total \\
\hline $30 / 06 / 2003$ & AT-202 & $\begin{array}{l}\text { Implementação do sistema de } \\
\text { informações da bacia hidrográfica do } \\
\text { Alto Tietê }\end{array}$ & Cancelado & $\mathrm{R} \$ 320.000,00$ & $\mathrm{R} \$ 400.000,00$ \\
\hline $30 / 06 / 2003$ & AT-203 & $\begin{array}{l}\text { Compensação aos municípios dos } \\
\text { mananciais do subcomitê Billings- } \\
\text { Tamanduateí }\end{array}$ & Cancelado & $\mathrm{R} \$ 60.000,00$ & $\mathrm{R} \$ 75.000,00$ \\
\hline $30 / 06 / 2003$ & AT-205 & $\begin{array}{l}\text { Diagnóstico preliminar da qualidade } \\
\text { ambiental da bacia hidrográfica do rio } \\
\text { Guaió }\end{array}$ & Concluído & $\mathrm{R} \$ 80.000,00$ & $\mathrm{R} \$ 101.028,40$ \\
\hline
\end{tabular}

Fonte: FEHIDRO, 2017, compilado pela autora. 


\section{ANEXO C - Síntese de projetos aprovados para recebimento de recursos financeiros do FEHIDRO}

Quadro 8 - Projetos aprovados que constam em deliberação do ano 2004.

\begin{tabular}{|c|c|c|c|c|c|}
\hline $\begin{array}{c}\text { Data } \\
\text { deliberação }\end{array}$ & Código & Nome do empreendimento & Situação & $\begin{array}{c}\text { Valor } \\
\text { pleiteado }\end{array}$ & Valor total \\
\hline $19 / 02 / 2004$ & AT-207 & \begin{tabular}{|l|} 
Ampliação da coleta seletiva de \\
materiais recicláveis do Embu
\end{tabular} & Concluído & $\mathrm{R} \$ 46.951,10$ & $\mathrm{R} \$ 134.151,10$ \\
\hline $19 / 02 / 2004$ & AT-208 & $\begin{array}{|lllr|}\text { PDPA para } & \text { o } & \text { subcomitê } & \text { Tietê- } \\
\text { Cabeceiras e leis } & \text { espefícias } & \text { para } \\
\text { proteção das APRM's } & & \\
\end{array}$ & Cancelado & $\mathrm{R} \$ 320.000,00$ & $\mathrm{R} \$ 400.000,00$ \\
\hline $07 / 05 / 2004$ & AT-209 & $\begin{array}{l}\text { Ampliação do programa socioambiental } \\
\text { de coleta seletiva }\end{array}$ & Concluído & $\mathrm{R} \$ 105.142,50$ & $\mathrm{R} \$ 131.445,70$ \\
\hline $07 / 05 / 2004$ & AT-210 & $\begin{array}{l}\text { Recomposição da mata ciliar do rio } \\
\text { Tietê - Ilha Marabá }\end{array}$ & \begin{tabular}{|c|} 
Em \\
execução
\end{tabular} & $\mathrm{R} \$ 83.909,00$ & $\mathrm{R} \$ 104.906,25$ \\
\hline $07 / 05 / 2004$ & AT-214 & $\begin{array}{l}\text { Implantação do centro de triagem de } \\
\text { resíduos sólidos }\end{array}$ & Concluído & $\mathrm{R} \$ 80.000,00$ & $\mathrm{R} \$ 100.000,00$ \\
\hline $07 / 05 / 2004$ & AT-215 & \begin{tabular}{|l|l|}
$\begin{array}{l}\text { Aquisição de containers para coleta } \\
\text { seletiva }\end{array}$ \\
\end{tabular} & Concluído & $\mathrm{R} \$ 60.800,00$ & $\mathrm{R} \$ 89.850,00$ \\
\hline $07 / 05 / 2004$ & AT-216 & \begin{tabular}{|l|} 
Elaboração do projeto executivo para \\
serviços e obras de proteção, \\
recuperação e conservação ambiental da \\
bacia do Sapiatã
\end{tabular} & Concluído & $\mathrm{R} \$ 40.000,00$ & $\mathrm{R} \$ 48.000,00$ \\
\hline $07 / 05 / 2004$ & AT-217 & \begin{tabular}{|l|} 
Programa de comunicação social, \\
educação ambiental e gestão de recursos \\
hídricos na bacia do Sapiatã
\end{tabular} & Concluído & $\mathrm{R} \$ 80.000,00$ & $\mathrm{R} \$ 100.000,00$ \\
\hline $07 / 05 / 2004$ & AT-221 & \begin{tabular}{|l|} 
Agenda 21 da cidade de Barueri - \\
construindo uma Barueri sustentável
\end{tabular} & Concluído & $\mathrm{R} \$ 31.643,72$ & $\mathrm{R} \$ 130.266,72$ \\
\hline $07 / 05 / 2004$ & AT-223 & Programa de educação ambiental & Concluído & 50 &, 28 \\
\hline $19 / 02 / 2004$ & AT-224 & $\begin{array}{l}\text { eferência em gerenciamento } \\
\text { hídricos }\end{array}$ & $\begin{array}{c}\text { Em } \\
\text { execução }\end{array}$ & $\mathrm{R} \$ 96.000,00$ & $\mathrm{R} \$ 120.000,00$ \\
\hline $07 / 05 / 2004$ & AT-225 & $\begin{array}{l}\text { Projeto de comunicação e educação } \\
\text { ambiental - Expo Juca Vivo }\end{array}$ & Concluído & $\mathrm{R} \$ 69.625,90$ & $\mathrm{R} \$ 69.625,90$ \\
\hline $07 / 05 / 2004$ & AT-226 & $\begin{array}{l}\text { Mobilização pela implantação do } \\
\text { circuito rodoviário ecoturistico Serra da } \\
\text { Cantareira }\end{array}$ & $\begin{array}{c}\text { Em } \\
\text { execução }\end{array}$ & $\mathrm{R} \$ 203.400,00$ & $\mathrm{R} \$ 256.871,00$ \\
\hline $07 / 05 / 2004$ & AT-227 & $\begin{array}{l}\text { Capacitação técnica da sociedade civil } \\
\text { do Bilings Tamanduateí }\end{array}$ & Concluído & $\mathrm{R} \$ 99.640,27$ & $\mathrm{R} \$ 124.665,27$ \\
\hline $07 / 05 / 2004$ & AT-228 & $\begin{array}{l}\text { Reciclarte II - programa de educação } \\
\text { ambiental }\end{array}$ & Concluído & $\mathrm{R} \$ 100.092,64$ & 115,80 \\
\hline $07 / 05 / 2004$ & AT-229 & $\begin{array}{l}\text { Chão Verde Terra Firme IV - programa } \\
\text { de educação ambiental }\end{array}$ & Concluído & $\mathrm{R} \$ 116.209,60$ & $\mathrm{R} \$ 130.609,60$ \\
\hline $07 / 05 / 2004$ & AT-230 & \begin{tabular}{|l} 
Capacitação de representantes do CBH- \\
AT e seus cinco subcomitês \\
utilização de ferramentas \\
geoprocessamento
\end{tabular} & Concluído & $\mathrm{R} \$ 171.600,00$ & $\mathrm{R} \$ 219.600,00$ \\
\hline $07 / 05 / 2004$ & AT-231 & $\begin{array}{l}\text { Seminário de avaliação e identificação } \\
\text { de áreas e ações prioritárias para } \\
\text { conservação }\end{array}$ & Concluído & $\mathrm{R} \$ 162.655,20$ & $\mathrm{R} \$ 203.455,20$ \\
\hline $07 / 05 / 2004$ & AT-232 & \begin{tabular}{|lr} 
Diagnóstico & socioambiental \\
participativo da região do subcomitê \\
Juquerí-Cantareira
\end{tabular} & Concluído & $\mathrm{R} \$ 68.500,00$ & $\mathrm{R} \$ 85.700,00$ \\
\hline
\end{tabular}

Continua 


\section{ANEXO C - Síntese de projetos aprovados para recebimento de recursos financeiros do FEHIDRO}

Quadro 8 - Projetos aprovados que constam em deliberação do ano 2004.

Continuação

\begin{tabular}{|c|c|c|c|c|c|}
\hline $\begin{array}{c}\text { Data } \\
\text { deliberação }\end{array}$ & Código & Nome do empreendimento & Situação & $\begin{array}{c}\text { Valor } \\
\text { pleiteado }\end{array}$ & Valor total \\
\hline $07 / 05 / 2004$ & AT-233 & $\begin{array}{l}\text { Avaliação da implementação das } \\
\text { propostas de ação e recomendações } \\
\text { resultantes do seminário Billings } 2002\end{array}$ & Concluído & $\mathrm{R} \$ 116.900,00$ & $\mathrm{R} \$ 146.900,00$ \\
\hline $07 / 05 / 2004$ & AT-234 & $\begin{array}{l}\text { Ampliação da rede telemétrica do Alto } \\
\text { Tietê - } 1^{\circ} \text { ano (área subcomitê Juquerí- } \\
\text { Cantareira) }\end{array}$ & Concluído & $\mathrm{R} \$ 38.940,00$ & $\mathrm{R} \$ 56.208,00$ \\
\hline 07/05/2004 & AT-235 & $\begin{array}{l}\text { Ampliação da rede telemétrica do Alto } \\
\text { Tietê }-1^{\circ} \text { ano (região Cotia- } \\
\text { Guarapiranga) }\end{array}$ & Concluído & $\mathrm{R} \$ 38.940,00$ & $\mathrm{R} \$ 56.208,00$ \\
\hline $07 / 05 / 2004$ & AT-236 & $\begin{array}{l}\text { Ampliação da rede telemétrica do Alto } \\
\text { Tietê }-1^{\circ} \text { ano (subcomitê Billings- } \\
\text { Tamanduateí) }\end{array}$ & Concluído & $\mathrm{R} \$ 77.880,00$ & $\mathrm{R} \$ 112.416,00$ \\
\hline $07 / 05 / 2004$ & AT-237 & $\begin{array}{l}\text { Ampliação da rede telemétrica do Alto } \\
\text { Tietê }-1^{\circ} \text { ano (subcomitê Tietê- } \\
\text { Cabeceiras) }\end{array}$ & Concluído & $\mathrm{R} \$ 116.820,00$ & $\mathrm{R} \$ 168.624,00$ \\
\hline $07 / 05 / 2004$ & AT-238 & $\begin{array}{l}\text { Centro de Treinamento em Recursos } \\
\text { Hídricos (CTRH) }-1^{\circ} \text { etapa }\end{array}$ & Concluído & $\mathrm{R} \$ 150.000,00$ & $\mathrm{R} \$ 187.500,00$ \\
\hline $07 / 05 / 2004$ & AT-239 & $\begin{array}{l}\text { Ampliação do Sistema de Alerta à } \\
\text { Inundações de São Paulo (SAISP) - } 1^{\circ} \\
\text { ano }\end{array}$ & Concluído & $\mathrm{R} \$ 476.800,00$ & $\mathrm{R} \$ 597.800,00$ \\
\hline $07 / 05 / 2004$ & AT-240 & $\begin{array}{lllll}\text { Projeto de redução da erosão } & \text { e } \\
\text { assoreamento } & -1^{\circ} \text { fase } & & & \\
\end{array}$ & Concluído & $\mathrm{R} \$ 177.550,00$ & $\mathrm{R} \$ 222.430,00$ \\
\hline 07/05/2004 & AT-241 & $\begin{array}{l}\text { Estudo experimental das características } \\
\text { hidráulicas de vertedores laretais }\end{array}$ & Concluído & $\mathrm{R} \$ 80.598,00$ & $\mathrm{R} \$ 102.000,00$ \\
\hline $07 / 05 / 2004$ & AT-242 & $\begin{array}{l}\text { Estudo de dispositivos e configurações } \\
\text { hidráulicas para atenuar o fluxo de lixo } \\
\text { aos piscinões }\end{array}$ & Concluído & $\mathrm{R} \$ 84.486,00$ & $\mathrm{R} \$ 108.000,00$ \\
\hline $07 / 05 / 2004$ & AT-243 & $\begin{array}{l}\begin{array}{l}\text { Sistema de gerenciamento de bacias } \\
\text { urbanas }\end{array} \\
\end{array}$ & Cancelado & $\mathrm{R} \$ 300.000,00$ & $\mathrm{R} \$ 375.000,00$ \\
\hline $07 / 05 / 2004$ & AT-244 & $\begin{array}{l}\text { Modelação unidimensional de transporte } \\
\text { de sedimentos em canais }\end{array}$ & Cancelado & $\mathrm{R} \$ 60.000,00$ & $\mathrm{R} \$ 75.000,00$ \\
\hline $07 / 05 / 2004$ & AT-245 & $\begin{array}{l}\text { Projeto de revitalização do viveiro de } \\
\text { mudas e adequação para pesquisa e } \\
\text { educação ambiental }\end{array}$ & Cancelado & $\mathrm{R} \$ 100.000,00$ & $\mathrm{R} \$ 125.000,00$ \\
\hline $07 / 05 / 2004$ & AT-246 & $\begin{array}{l}\text { Plano de desenvolvimento regional e } \\
\text { proteção ambiental e minuta de leis } \\
\text { espefícias para bacia do rio Cotia }\end{array}$ & Concluído & $\mathrm{R} \$ 320.000,00$ & $\mathrm{R} \$ 400.000,00$ \\
\hline $07 / 05 / 2004$ & AT-247 & $\begin{array}{l}\text { Programa de educação ambiental - Água } \\
\text { Viva }\end{array}$ & $\begin{array}{c}\text { Em } \\
\text { execução }\end{array}$ & $\mathrm{R} \$ 104.480,00$ & $\mathrm{R} \$ 130.600,00$ \\
\hline 07/05/2004 & AT-248 & $\begin{array}{l}\text { Atualização do PDPA da APRM } \\
\text { Guarapiranga }\end{array}$ & Concluído & $\mathrm{R} \$ 273.182,92$ & $\mathrm{R} \$ 367.762,92$ \\
\hline $07 / 05 / 2004$ & AT -250 & $\begin{array}{l}\text { Educação ambiental para educadores, } \\
\text { funcionários da saúde e setor privado }\end{array}$ & Concluído & $\mathrm{R} \$ 77.054,88$ & $\mathrm{R} \$ 96.334,12$ \\
\hline $07 / 05 / 2004$ & AT-251 & $\begin{array}{l}\text { Programa de fortalecimento da gestão } \\
\text { ambiental integrada do ABC }\end{array}$ & Concluído & $\mathrm{R} \$ 184.600,00$ & $\mathrm{R} \$ 237.240,00$ \\
\hline
\end{tabular}

Continua 


\section{ANEXO C - Síntese de projetos aprovados para recebimento de recursos financeiros do FEHIDRO}

Quadro 8 - Projetos aprovados que constam em deliberação do ano 2004.

Continuação

\begin{tabular}{|c|c|c|c|c|c|}
\hline $\begin{array}{c}\text { Data } \\
\text { deliberação }\end{array}$ & Código & Nome do empreendimento & Situação & $\begin{array}{c}\text { Valor } \\
\text { pleiteado }\end{array}$ & Valor total \\
\hline $07 / 05 / 2004$ & AT-254 & $\begin{array}{l}\text { Gerenciamento da APA da várzea do rio } \\
\text { Tietê }\end{array}$ & Concluído & $\mathrm{R} \$ 30.000,00$ & $\mathrm{R} \$ 37.500,00$ \\
\hline $07 / 05 / 2004$ & AT-256 & $\begin{array}{l}\text { Mobilização em educação ambiental e } \\
\text { práticas sustentáveis no entorno da } \\
\text { represa Billings - Distrito de Pedreira }\end{array}$ & Concluído & $\mathrm{R} \$ 73.006,00$ & $\mathrm{R} \$ 97.198,00$ \\
\hline $07 / 05 / 2004$ & AT-257 & $\begin{array}{l}\text { Mobilização em educação ambiental e } \\
\text { práticas sustentáveis no entorno da } \\
\text { represa Guarapiranga - Distrito Jd. } \\
\text { Angela }\end{array}$ & Concluído & $\mathrm{R} \$ 69.355,70$ & $\mathrm{R} \$ 93.547,70$ \\
\hline $07 / 05 / 2004$ & AT-258 & $\begin{array}{l}\text { Agenda } 21 \quad \text { e } \text { desenvolvimento } \\
\text { sustentável em áreas de mananciais }\end{array}$ & $\begin{array}{c}\text { Em } \\
\text { execução }\end{array}$ & $\mathrm{R} \$ 72.000,00$ & $\mathrm{R} \$ 94.540,00$ \\
\hline $07 / 05 / 2004$ & AT-259 & Agenda 21 escolar & Concluído & $\mathrm{R} \$ 54.240,00$ & $\mathrm{R} \$ 70.680,00$ \\
\hline $07 / 05 / 2004$ & AT-262 & $\begin{array}{l}\text { Fortalecimento institucional do } \\
\text { subcomitê da bacia hidrográfica } \\
\text { Pinheiros-Pirapora }\end{array}$ & Concluído & $\mathrm{R} \$ 80.000,00$ & $\mathrm{R} \$ 103.940,00$ \\
\hline $07 / 05 / 2004$ & AT-263 & $\begin{array}{l}\text { Ferramentas para a gestão integrada da } \\
\text { BH-AT }\end{array}$ & Concluído & $\mathrm{R} \$ 151.529,00$ & $\mathrm{R} \$ 189.411,25$ \\
\hline $19 / 02 / 2004$ & AT-264 & $\begin{array}{l}\text { Sistema de informação e comunicação } \\
\text { do Alto Tietê - o uso de ferramentas } \\
\text { comunicacionais para educação } \\
\text { ambiental }\end{array}$ & Concluído & $\mathrm{R} \$ 173.134,05$ & $\mathrm{R} \$ 216.417,56$ \\
\hline $07 / 05 / 2004$ & AT-268 & $\begin{array}{l}\text { Projeto de integração do CBH-AT - } \\
\text { parlamento das águas }\end{array}$ & Concluído & $\mathrm{R} \$ 194.800,00$ & $\mathrm{R} \$ 243.500,00$ \\
\hline $29 / 06 / 2004$ & AT-269 & $\begin{array}{l}\text { Valoração econômica dos serviços } \\
\text { ambientais prestados pelas áreas } \\
\text { florestadas da bacia da represa Billings }\end{array}$ & Concluído & $\mathrm{R} \$ 140.756,92$ & $\mathrm{R} \$ 220.756,92$ \\
\hline $29 / 06 / 2004$ & AT-270 & $\begin{array}{l}\text { Marco pedagógico de "O rio e os } \\
\text { trilhos" }\end{array}$ & Concluído & $\mathrm{R} \$ 33.638,50$ & $\mathrm{R} \$ 45.386,50$ \\
\hline $29 / 06 / 2004$ & AT-271 & Juca vivo - capacita subcomitê & Concluído & $\mathrm{R} \$ 87.151,00$ & $\mathrm{R} \$ 87.151,00$ \\
\hline $27 / 07 / 2004$ & AT-317 & $\begin{array}{l}\text { Protetores da água - formação de } \\
\text { agentes multiplicadores } \\
\text { Pirapora) }\end{array}$ & $\begin{array}{c}\text { Em } \\
\text { execução }\end{array}$ & $\mathrm{R} \$ 95.000,00$ & $\mathrm{R} \$ 140.120,00$ \\
\hline
\end{tabular}

Fonte: FEHIDRO, 2017, compilado pela autora. 


\section{ANEXO C - Síntese de projetos aprovados para recebimento de recursos financeiros do FEHIDRO}

Quadro 9 - Projetos aprovados que constam em deliberação do ano 2005.

\begin{tabular}{|c|c|c|c|c|c|}
\hline $\begin{array}{c}\text { Data } \\
\text { deliberação }\end{array}$ & Código & Nome do empreendimento & Situação & $\begin{array}{c}\text { Valor } \\
\text { pleiteado }\end{array}$ & Valor total \\
\hline $27 / 07 / 2005$ & AT-274 & $\begin{array}{l}\text { Indicação de áreas de intervenção e das } \\
\text { estratégias e prioridades para ação na } \\
\text { bacia hidrográfica do rio Guaió }\end{array}$ & Cancelado & $\mathrm{R} \$ 106.000,64$ & $\mathrm{R} \$ 133.246,28$ \\
\hline $27 / 07 / 2005$ & AT-275 & $\begin{array}{l}\text { Capacitação e treinamento para a gestão } \\
\text { ambiental - plano de qualidade de vida e } \\
\text { cidadania }\end{array}$ & Cancelado & $\mathrm{R} \$ 8.525,00$ & $\mathrm{R} \$ 10.865,00$ \\
\hline $27 / 07 / 2005$ & AT-276 & $\begin{array}{l}\text { Diretrizes e ações para proteção e } \\
\text { controle dos impactos decorrentes dos } \\
\text { processos erosivos na BH-AT - UGRHI } \\
6 \text { - Etapa } 1\end{array}$ & Concluído & $\mathrm{R} \$ 143.463,00$ & $\mathrm{R} \$ 192.463,00$ \\
\hline $27 / 07 / 2005$ & AT-277 & $\begin{array}{l}\text { Construção de travessia em aduelas de } \\
\text { concreto - barragem Ponte Nova - bairro } \\
\text { Aterrado }\end{array}$ & Concluído & $\mathrm{R} \$ 167.040,58$ & $\mathrm{R} \$ 259.410,58$ \\
\hline $27 / 07 / 2005$ & AT-278 & $\begin{array}{l}\text { Operacionalização do centro de triagem } \\
\text { de resíduos sólidos e implantação do } \\
\text { programa socioambiental de coleta } \\
\text { seletiva }\end{array}$ & Cancelado & $\mathrm{R} \$ 78.481,20$ & $\mathrm{R} \$ 98.382,20$ \\
\hline $27 / 07 / 2005$ & AT-279 & $\begin{array}{l}\text { Capacitação de lideranças comunitárias } \\
\text { para a difusão da educção ambiental na } \\
\text { região da subprefeitura de M'Bio Mirim }\end{array}$ & $\begin{array}{c}\text { Em } \\
\text { execução }\end{array}$ & $\mathrm{R} \$ 75.487,20$ & $\mathrm{R} \$ 95.191,20$ \\
\hline $27 / 07 / 2005$ & AT-280 & $\begin{array}{l}\text { Ampliação do sistema de alerta à } \\
\text { Inundações de São Paulo (SAISP) - } 2^{\circ} \\
\text { ano }\end{array}$ & Concluído & $\mathrm{R} \$ 61.000,00$ & $\mathrm{R} \$ 76.600,00$ \\
\hline $27 / 07 / 2005$ & AT-281 & $\begin{array}{l}\text { Ampliação da rede telemétrica do Alto } \\
\text { Tietê }-2^{\circ} \text { ano (subcomitê Billings- } \\
\text { Tamanduateí) }\end{array}$ & Concluído & $\mathrm{R} \$ 17.200,00$ & $\mathrm{R} \$ 21.600,00$ \\
\hline $27 / 07 / 2005$ & AT-282 & $\begin{array}{l}\text { Ampliação da rede telemétrica do Alto } \\
\text { Tietê }-2^{\circ} \text { ano (subcomitê Juqueri- } \\
\text { Cantareira) }\end{array}$ & Concluído & $\mathrm{R} \$ 8.400,00$ & $\mathrm{R} \$ 10.800,00$ \\
\hline $27 / 07 / 2005$ & AT-283 & $\begin{array}{l}\text { Ampliação do sistema de } \\
\text { monitoramento e divulgação dos dados } \\
\text { de qualidade das águas gerados pela } \\
\text { rede automática }\end{array}$ & Concluído & $\mathrm{R} \$ 93.480,00$ & $\mathrm{R} \$ 93.480,00$ \\
\hline $27 / 07 / 2005$ & AT-284 & \begin{tabular}{|l} 
Capacitação de organizações da \\
sociedade civil da região do subcomitê \\
Cotia-Guarapiranga em gestão e \\
elaboração de projetos socioambientais
\end{tabular} & Concluído & $\mathrm{R} \$ 136.000,00$ & $\mathrm{R} \$ 169.990,00$ \\
\hline $27 / 07 / 2005$ & AT-285 & Criação de site - projeto & Concluído & $\mathrm{R} \$ 184.585,00$ & $\mathrm{R} \$ 278.005,00$ \\
\hline $27 / 07 / 2005$ & AT-286 & Projeto de gestão ambiental partcipativa & Concluído & $\mathrm{R} \$ 95.510,00$ & $\mathrm{R} \$ 133.994,96$ \\
\hline $27 / 07 / 2005$ & AT-287 & $\begin{array}{l}\text { Formação de professores: agentes } \\
\text { multiplicadores do SIGRH - Cidade } \\
\text { Ademar/ Ribeirão Pires }\end{array}$ & Concluído & $\mathrm{R} \$ 80.000,00$ & $\mathrm{R} \$ 100.000,00$ \\
\hline $27 / 07 / 2005$ & AT-288 & $\begin{array}{l}\text { Identificação visual da área de proteção } \\
\text { e recuperção de mananciais Billings }\end{array}$ & Concluído & $\mathrm{R} \$ 47.600,00$ & $\mathrm{R} \$ 59.514,58$ \\
\hline $27 / 07 / 2005$ & AT-289 & $\begin{array}{l}\text { Cidadania e educação ambiental na área } \\
\text { de recursos hídricos }\end{array}$ & Concluído & $\mathrm{R} \$ 258.840,00$ & $\mathrm{R} \$ 323.560,00$ \\
\hline $27 / 07 / 2005$ & AT-290 & $\begin{array}{l}\text { Agenda } 21 \text { escolar - educação ambiental } \\
\text { em área de proteção aos mananciais }\end{array}$ & Concluído & $\mathrm{R} \$ 74.480,00$ & $\mathrm{R} \$ 100.144,00$ \\
\hline
\end{tabular}




\section{ANEXO C - Síntese de projetos aprovados para recebimento de recursos financeiros do FEHIDRO}

Quadro 9 - Projetos aprovados que constam em deliberação do ano 2005.

Continuação

\begin{tabular}{|c|c|c|c|c|c|}
\hline $\begin{array}{c}\text { Data } \\
\text { deliberação }\end{array}$ & Código & Nome do empreendimento & Situação & $\begin{array}{c}\text { Valor } \\
\text { pleiteado }\end{array}$ & Valor total \\
\hline $27 / 07 / 2005$ & AT-291 & $\begin{array}{l}\text { Capacitação técnica da sociedade civil } \\
\text { do Pinheiros Pirapora }\end{array}$ & Concluído & $\mathrm{R} \$ 99.640,27$ & $\mathrm{R} \$ 124.665,27$ \\
\hline $27 / 07 / 2005$ & AT-292 & \begin{tabular}{|l} 
Projeto "Comunidade presente \\
educação ambiental"
\end{tabular} & $\begin{array}{c}\text { Em } \\
\text { execução }\end{array}$ & $\mathrm{R} \$ 39.718,90$ & $\mathrm{R} \$ 49.718,90$ \\
\hline $27 / 07 / 2005$ & AT-293 & 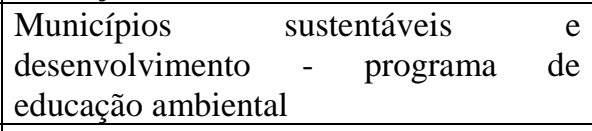 & Concluído & $\mathrm{R} \$ 113.870,97$ & $\mathrm{R} \$ 142.540,05$ \\
\hline $27 / 07 / 2005$ & AT-294 & $\begin{array}{l}\text { Levantamento socioambiental da região } \\
\text { do Baixo Alvarenga e curso de } \\
\text { capacitação de gestores ambientais }\end{array}$ & $\begin{array}{c}\text { Em } \\
\text { execução }\end{array}$ & $\mathrm{R} \$ 150.672,40$ & $\mathrm{R} \$ 188.338,00$ \\
\hline $27 / 07 / 2005$ & AT-295 & Fórum da sociedade civil no CBH-AT & Concluído & $\mathrm{R} \$ 111.566,00$ & $\mathrm{R} \$ 139.457,00$ \\
\hline $27 / 07 / 2005$ & AT-296 & $\begin{array}{l}\text { Capacitação técnica da sociedade civil } \\
\text { do Bilings Tamanduateí }\end{array}$ & Concluído & $\mathrm{R} \$ 99.640,27$ & $\mathrm{R} \$ 124.665,27$ \\
\hline $27 / 07 / 2005$ & AT-297 & $\begin{array}{l}\text { Revitalização do córrego Bussocaba } \\
\text { (Osasco) }\end{array}$ & Concluído & $\mathrm{R} \$ 33.040,00$ & $\mathrm{R} \$ 50.740,00$ \\
\hline $27 / 07 / 2005$ & AT-298 & $\begin{array}{l}\text { Associação do verde e proteção do meio } \\
\text { ambiente - AVEPEMA }\end{array}$ & Concluído & $\mathrm{R} \$ 80.000,00$ & $\mathrm{R} \$ 100.000,00$ \\
\hline $27 / 07 / 2005$ & AT-299 & $\begin{array}{l}\text { Formação de professores: } \\
\text { multiplicadores do SIGRH } \\
\text { Grande/ Embu }\end{array}$ & Concluído & $\mathrm{R} \$ 80.000,00$ & $\mathrm{R} \$ 100.000,00$ \\
\hline $27 / 07 / 2005$ & AT-300 & $\begin{array}{l}\text { Projeto mídia ambiente II: comunicação } \\
\text { social }\end{array}$ & Concluído & $\mathrm{R} \$ 188.626,00$ & $\mathrm{R} \$ 239.826,00$ \\
\hline $27 / 07 / 2005$ & AT-302 & $\begin{array}{l}\text { Programa de comunicação e integração } \\
\text { do Alto Tietê-Cabeceiras }\end{array}$ & Concluído & $\mathrm{R} \$ 99.985,00$ & $\mathrm{R} \$ 127.285,00$ \\
\hline $27 / 07 / 2005$ & AT-303 & $\begin{array}{l}\text { Canalização de trecho do córrego Itaim } \\
\text { (Poá) }\end{array}$ & Concluído & $\mathrm{R} \$ 181.511,85$ & $\mathrm{R} \$ 236.889,83$ \\
\hline $27 / 07 / 2005$ & AT-304 & $\begin{array}{l}\text { Intervenção tecnológica do uso racional } \\
\text { da água para redução de perdas em } \\
\text { escolas municipais }\end{array}$ & $\begin{array}{c}\text { Em } \\
\text { execução }\end{array}$ & $\mathrm{R} \$ 203.425,00$ & $\mathrm{R} \$ 257.500,00$ \\
\hline 06/07/2005 & AT-305 & Revisão do Plano da BH-AT & Concluído & $\mathrm{R} \$ 700.000,00$ & $\mathrm{R} \$ 875.000,00$ \\
\hline $27 / 07 / 2005$ & AT-306 & $\begin{array}{l}\text { Ampliação da rede telemétrica do Alto } \\
\text { Tietê }-2^{\circ} \text { ano (subcomitê Tietê- } \\
\text { Cabeceiras) }\end{array}$ & Concluído & $\mathrm{R} \$ 26.000,00$ & $\mathrm{R} \$ 32.520,00$ \\
\hline $27 / 07 / 2005$ & AT-307 & $\begin{array}{l}\text { Programa de Limpeza Emergencial de } \\
\text { Rios e Córregos - PROLIMPE - } 1^{\circ} \\
\text { etapa }\end{array}$ & Concluído & $\mathrm{R} \$ 880.000,00$ & $\mathrm{R} \$ 880.000,00$ \\
\hline $27 / 07 / 2005$ & AT-308 & $\begin{array}{l}\text { Adequação de aterro sanitário (Biritiba- } \\
\text { Mirim) }\end{array}$ & Concluído & $\mathrm{R} \$ 125.414,80$ & $\mathrm{R} \$ 204.396,38$ \\
\hline $27 / 07 / 2005$ & AT-309 & $\begin{array}{l}\text { Projeto olhos d'água - formação de } \\
\text { agentes ambientais } \\
\text { Guarapiranga) }\end{array}$ & $\begin{array}{c}\text { Em } \\
\text { execução }\end{array}$ & $\mathrm{R} \$ 45.064,00$ & $\mathrm{R} \$ 56.898,00$ \\
\hline $27 / 07 / 2005$ & AT-310 & $\begin{array}{l}\text { Projeto olhos d'água - formação de } \\
\text { agentes ambientais (Pinheiros-Pirapora) }\end{array}$ & $\begin{array}{c}\text { Em } \\
\text { execução }\end{array}$ & $\mathrm{R} \$ 45.064,00$ & $\mathrm{R} \$ 56.898,00$ \\
\hline $27 / 07 / 2005$ & AT-311 & $\begin{array}{l}\text { Projeto olhos d'água - formação de } \\
\text { agentes ambientais } \\
\text { Tamanduateí) }\end{array}$ & $\begin{array}{c}\text { Em } \\
\text { execução }\end{array}$ & $\mathrm{R} \$ 45.064,00$ & $\mathrm{R} \$ 56.898,00$ \\
\hline
\end{tabular}




\section{ANEXO C - Síntese de projetos aprovados para recebimento de recursos financeiros do FEHIDRO}

Quadro 9 - Projetos aprovados que constam em deliberação do ano 2005.

Continuação

\begin{tabular}{|c|c|l|c|c|c|}
\hline $\begin{array}{c}\text { Data } \\
\text { deliberação }\end{array}$ & Código & \multicolumn{1}{|c|}{ Nome do empreendimento } & Situação & $\begin{array}{c}\text { Valor } \\
\text { pleiteado }\end{array}$ & Valor total \\
\hline $27 / 07 / 2005$ & AT-312 & $\begin{array}{l}\text { Protetores da água - formação de } \\
\text { agentes multiplicadores }\end{array}$ & $\begin{array}{c}\text { Em } \\
\text { execução }\end{array}$ & $\mathrm{R} \$ 177.770,00$ & $\mathrm{R} \$ 222.890,00$ \\
\hline $27 / 07 / 2005$ & $\mathrm{AT}-313$ & Cine a história da água & Concluído & $\mathrm{R} \$ 179.331,00$ & $\mathrm{R} \$ 245.521,00$ \\
\hline $27 / 07 / 2005$ & AT-314 & $\begin{array}{l}\text { Fomento à fiscalização integrada da } \\
\text { bacia hidrográfica do Guarapiranga }\end{array}$ & Cancelado & $\mathrm{R} \$ 100.181,16$ & $\mathrm{R} \$ 126.912,16$ \\
\hline $27 / 07 / 2005$ & AT-315 & $\begin{array}{l}\text { Centro de treinamento em Recursos } \\
\text { Hídricos (CTRH) - 2ºtapa }\end{array}$ & Concluído & $\mathrm{R} \$ 190.000,00$ & $\mathrm{R} \$ 244.100,00$ \\
\hline $27 / 07 / 2005$ & AT-318 & $\begin{array}{l}\text { Fórum de difusão Tietê Vivo - ciência, } \\
\text { ação social e sustentabilidade da BH-AT }\end{array}$ & Concluído & $\mathrm{R} \$ 150.000,00$ & $\mathrm{R} \$ 194.900,00$ \\
\hline $27 / 07 / 2005$ & AT-319 & $\begin{array}{l}\text { Produção de vídeo ambiental da bacia } \\
\text { hidrográfica do Guarapiranga }\end{array}$ & Concluído & $\mathrm{R} \$ 69.600,00$ & $\mathrm{R} \$ 87.000,00$ \\
\hline $27 / 07 / 2005$ & AT-322 & $\begin{array}{l}\text { Fortalecimento institucional do } \\
\text { subcomitê Pinheiros-Pirapora - curso de } \\
\text { capacitação }\end{array}$ & Concluído & $\mathrm{R} \$ 93.080,00$ & $\mathrm{R} \$ 133.880,00$ \\
\hline $27 / 07 / 2005$ & AT-323 & $\begin{array}{l}\text { Plantio de mudas em escolas e programa } \\
\text { de educação ambiental }\end{array}$ & Concluído & $\mathrm{R} \$ 108.200,00$ & $\mathrm{R} \$ 161.512,00$ \\
\hline $27 / 07 / 2005$ & AT-327 & $\begin{array}{l}\text { Mobilização em educação ambiental e } \\
\text { práticas sustentáveis no entorno da } \\
\text { represa Billings - Distrito de Pedreira }\end{array}$ & Concluído & $\mathrm{R} \$ 64.821,00$ & $\mathrm{R} \$ 81.141,00$ \\
\hline
\end{tabular}

Fonte: FEHIDRO, 2017, compilado pela autora. 


\section{ANEXO C - Síntese de projetos aprovados para recebimento de recursos financeiros do FEHIDRO}

Quadro 10 - Projetos aprovados que constam em deliberação do ano 2006.

\begin{tabular}{|c|c|c|c|c|c|}
\hline $\begin{array}{c}\text { Data } \\
\text { deliberação }\end{array}$ & Código & Nome do empreendimento & Situação & $\begin{array}{c}\text { Valor } \\
\text { pleiteado }\end{array}$ & Valor total \\
\hline $29 / 06 / 2006$ & AT-328 & $\begin{array}{l}\text { Apoio à adequação da infraestrutura da } \\
\text { secretaria executiva do CBH-AT e } 5 \\
\text { subcomitês }\end{array}$ & Cancelado & $\mathrm{R} \$ 80.000,00$ & $\mathrm{R} \$ 80.000,00$ \\
\hline $29 / 06 / 2006$ & AT-329 & $\begin{array}{l}\text { Execução de estudos técnicos visando a } \\
\text { colaboração com o Plano Diretor de } \\
\text { Macrodrenagem para a bacia do rio } \\
\text { Pinheiros }\end{array}$ & Concluído & $\mathrm{R} \$ 177.843,01$ & $\mathrm{R} \$ 239.358,01$ \\
\hline $29 / 06 / 2006$ & AT-331 & $\begin{array}{l}\text { Conexão das águas: participação social } \\
\text { na cobrança de uso de água }\end{array}$ & Concluído & $\mathrm{R} \$ 70.840,00$ & $\mathrm{R} \$ 94.060,00$ \\
\hline $29 / 06 / 2006$ & AT-332 & $\begin{array}{l}\text { Capacitação de agentes vistores e } \\
\text { agentes técnicos em controle ambiental } \\
\text { para a fiscalização integrada, nas áreas } \\
\text { de mananciais na cidade de São Paulo } \\
\end{array}$ & Concluído & $\mathrm{R} \$ 52.780,00$ & $\mathrm{R} \$ 77.780,00$ \\
\hline 29/06/2006 & AT-336 & $\begin{array}{|lll|}\text { Desenvolvimento de } & \text { sistema de } \\
\text { indicadores ambientais } & \text { aplicáveis à } \\
\text { gestão das APRM's situadas na UGRHI } \\
\text { 6: Projeto geo bacias }\end{array}$ & Concluído & $\mathrm{R} \$ 185.000,00$ & $\mathrm{R} \$ 285.540,00$ \\
\hline $29 / 06 / 2006$ & AT-337 & $\begin{array}{l}\text { Plano de gestão integrada de resíduos } \\
\text { sólidos em área de proteção de } \\
\text { mananciais }\end{array}$ & Concluído & $\mathrm{R} \$ 87.160,00$ & $\mathrm{R} \$ 108.950,00$ \\
\hline $29 / 06 / 2006$ & AT-338 & $\begin{array}{l}\text { Educonservação ambiental - Jardim } \\
\text { Ângela/ Guarapiranga }\end{array}$ & \begin{tabular}{c|c|} 
Em \\
execução
\end{tabular} & $\mathrm{R} \$ 68.175,00$ & $\mathrm{R} \$ 88.815,00$ \\
\hline $29 / 06 / 2006$ & AT-340 & $\begin{array}{l}\text { Diagnóstico socioambiental da bacia } \\
\text { hidrográfica do município de Embu - } \\
\text { atlas socioambiental de Embu }\end{array}$ & Concluído & $\mathrm{R} \$ 84.456,00$ & $\mathrm{R} \$ 159.099,60$ \\
\hline $29 / 06 / 2006$ & AT-345 & $\begin{array}{|lr|}\text { Fortalecimento institucional do } \\
\text { subcomitê Pinheiros-Pirapora } & \text { - gestão } \\
\text { da comunicação } & \\
\end{array}$ & Concluído & $\mathrm{R} \$ 121.598,98$ & $\mathrm{R} \$ 152.398,98$ \\
\hline $29 / 06 / 2006$ & AT-346 & Projeto de olho nos mananciais - fase II & Concluído & $\mathrm{R} \$ 317.221,00$ & $\mathrm{R} \$ 403.346,00$ \\
\hline $29 / 06 / 2006$ & AT-347 & $\begin{array}{l}\text { Monitoramento automático das águas } \\
\text { superficiais da sub-bacia Juquery- } \\
\text { Cantateira }\end{array}$ & Concluído & $\mathrm{R} \$ 254.996,00$ & $\mathrm{R} \$ 318.828,10$ \\
\hline $29 / 06 / 2006$ & AT-349 & $\begin{array}{l}\text { Plano integrado de gerenciamento } \\
\text { regional dos resíduos da construção civil } \\
\text { e resíduos volumosos e de projetos } \\
\text { interligados nos municípios do Alto } \\
\text { Tietê-Cabeceiras }\end{array}$ & Concluído & $\mathrm{R} \$ 99.012,78$ & $\mathrm{R} \$ 123.912,53$ \\
\hline 29/06/2006 & AT-350 & $\begin{array}{l}\text { Projeto Yporã - proliferação de plantas } \\
\text { aquáticas da represa do Guarapiranga }\end{array}$ & Concluído & $\mathrm{R} \$ 127.390,29$ & $\mathrm{R} \$ 184.990,29$ \\
\hline 29/06/2006 & AT-352 & $\begin{array}{l}\text { Ampliação do (SAISP) - Sistema de } \\
\text { alerta à inundações de São Paulo - } 3^{\circ} \\
\text { ano }\end{array}$ & Concluído & $\mathrm{R} \$ 167.360,00$ & $\mathrm{R} \$ 211.260,00$ \\
\hline $29 / 06 / 2006$ & AT-364 & $\begin{array}{l}\text { Implantação da EFA-Billings - Escola } \\
\text { de formação ambiental Billings }\end{array}$ & Concluído & $\mathrm{R} \$ 182.690,00$ & $\mathrm{R} \$ 312.771,40$ \\
\hline 29/06/2006 & AT-366 & $\begin{array}{|lll|}\text { Modelagem } & \text { tridimensional } & \text { da } \\
\text { hidrodinâmica } & \text { do } \quad \text { reservatório } & \text { do } \\
\text { Guarapiranga } & & \end{array}$ & Concluído & $\mathrm{R} \$ 135.063,63$ & $\mathrm{R} \$ 225.120,19$ \\
\hline
\end{tabular}

Continua 


\section{ANEXO C - Síntese de projetos aprovados para recebimento de recursos financeiros do FEHIDRO}

Quadro 10 - Projetos aprovados que constam em deliberação do ano 2006.

Continuação

\begin{tabular}{|c|c|l|l|l|l|}
\hline $\begin{array}{c}\text { Data } \\
\text { deliberação }\end{array}$ & Código & \multicolumn{1}{|c|}{ Nome do empreendimento } & Situação & \multicolumn{1}{|c|}{$\begin{array}{c}\text { Valor } \\
\text { pleiteado }\end{array}$} & Valor total \\
\hline $29 / 06 / 2006$ & AT-370 & $\begin{array}{l}\text { Elaboração do Plano Diretor de } \\
\text { Macrodrenagem do município de } \\
\text { Suzano }\end{array}$ & Concluído & $\mathrm{R} \$ 146.034,00$ & $\mathrm{R} \$ 182.946,00$ \\
\hline $29 / 06 / 2006$ & AT-371 & $\begin{array}{l}\text { PROLIMPE - Programa de Limpeza } \\
\text { Emergencial de Rios e Córregos - 2 } \\
\text { etapa }\end{array}$ & Cancelado & $\mathrm{R} \$ 360.000,00$ & $\mathrm{R} \$ 360.000,00$ \\
\hline $29 / 06 / 2006$ & AT-374 & $\begin{array}{l}\text { Implantação de núcleo de educação } \\
\text { ambiental no município de Pirapora do } \\
\text { Bom Jesus }\end{array}$ & Concluído & $\mathrm{R} \$ 42.230,00$ & $\mathrm{R} \$ 80.951,00$ \\
\hline $29 / 06 / 2006$ & AT-375 & $\begin{array}{l}\text { Construção de galpão para triagem de } \\
\text { materiais recicláveis }\end{array}$ & Concluído & $\mathrm{R} \$ 187.585,07$ & $\mathrm{R} \$ 244.790,07$ \\
\hline $29 / 06 / 2006$ & AT-381 & $\begin{array}{l}\text { Adequação e controle da ocupação da } \\
\text { área de preservação permanente das } \\
\text { margens do reservatório guarapiranga }\end{array}$ & Cancelado & $\mathrm{R} \$ 122.000,00$ & $\mathrm{R} \$ 152.000,00$ \\
\hline $29 / 06 / 2006$ & AT-382 & $\begin{array}{l}\text { Estudos e serviços técnicos em apoio à } \\
\text { implantação da cobrança pelo uso da } \\
\text { água na UGHRI 6 fase I }\end{array}$ & Concluído & $\mathrm{R} \$ 200.000,00$ & $\mathrm{R} \$ 200.000,00$ \\
\hline
\end{tabular}

Fonte: FEHIDRO, 2017, compilado pela autora. 


\section{ANEXO C - Síntese de projetos aprovados para recebimento de recursos financeiros do FEHIDRO}

Quadro 11 - Projetos aprovados que constam em deliberação do ano 2008.

\begin{tabular}{|c|c|c|c|c|c|}
\hline $\begin{array}{c}\text { Data } \\
\text { deliberação }\end{array}$ & Código & Nome do empreendimento & Situação & $\begin{array}{c}\text { Valor } \\
\text { pleiteado }\end{array}$ & Valor total \\
\hline $31 / 03 / 2008$ & AT-386 & $\begin{array}{l}\text { Projeto curso de formação em } \\
\text { saneamento ambiental na região do } \\
\text { Pinheiros, Ipiranga e Billings } \\
\end{array}$ & Concluído & $\mathrm{R} \$ 195.067,50$ & $\mathrm{R} \$ 248.686,14$ \\
\hline $31 / 03 / 2008$ & AT-387 & $\begin{array}{l}\text { Projeto interação socioambiental da } \\
\text { Billings - Programa de gestão ambiental } \\
\text { participativa }\end{array}$ & $\begin{array}{c}\text { Em } \\
\text { execução }\end{array}$ & $\mathrm{R} \$ 196.713,20$ & $\mathrm{R} \$ 245.955,20$ \\
\hline $31 / 03 / 2008$ & AT-391 & $\begin{array}{l}\text { Centro de estudos e recuperação } \\
\text { ambiental }\end{array}$ & Concluído & $\mathrm{R} \$ 309.152,70$ & $\mathrm{R} \$ 572.992,00$ \\
\hline $31 / 03 / 2008$ & AT-392 & Turminha das águas & $\begin{array}{c}\text { Em } \\
\text { execução }\end{array}$ & $\mathrm{R} \$ 238.949,60$ & $\mathrm{R} \$ 299.945,60$ \\
\hline $31 / 03 / 2008$ & AT-393 & Comunicação institucional do CBH-AT & $\begin{array}{c}\text { Em } \\
\text { execução }\end{array}$ & $\mathrm{R} \$ 238.267,50$ & $\mathrm{R} \$ 299.395,50$ \\
\hline $31 / 03 / 2008$ & AT-394 & $\begin{array}{l}\text { Despoluição de óleo vegetal na bacia do } \\
\text { tietê cabeceiras }\end{array}$ & $\begin{array}{c}\text { Em } \\
\text { execução }\end{array}$ & $\mathrm{R} \$ 99.900,00$ & $\mathrm{R} \$ 169.900,00$ \\
\hline $31 / 03 / 2008$ & AT-396 & $\begin{array}{l}\text { Plano de manejo participativo para o } \\
\text { Parque Natural Municipal Pedra Bonita }\end{array}$ & Concluído & $\mathrm{R} \$ 151.555,20$ & $\mathrm{R} \$ 189.444,00$ \\
\hline $31 / 03 / 2008$ & AT-398 & $\begin{array}{l}\text { Projeto fonte da vida - formação de } \\
\text { professores para atuação como agentes } \\
\text { multiplicadores do SIGRH na região dos } \\
\text { subcomitês Juqueri-Cantareira e Alto } \\
\text { Tietê-Cabeceiras }\end{array}$ & $\begin{array}{c}\text { Em } \\
\text { execução }\end{array}$ & $\mathrm{R} \$ 208.040,90$ & $\mathrm{R} \$ 267.473,22$ \\
\hline $31 / 03 / 2008$ & AT-399 & $\begin{array}{l}\text { Desenvolvimento do sistema de suporte } \\
\text { à decisão da bacia do Alto Tietê }\end{array}$ & $\begin{array}{c}\text { Em } \\
\text { execução }\end{array}$ & $\mathrm{R} \$ 213.300,00$ & $\mathrm{R} \$ 266.600,00$ \\
\hline $31 / 03 / 2008$ & AT-400 & $\begin{array}{l}\text { Centro de triagem na bacia do } \\
\text { Taiassupeba, reciclando materiais para } \\
\text { um ambiente sustentável }\end{array}$ & Concluído & $\mathrm{R} \$ 671.150,28$ & $\mathrm{R} \$ 849.557,32$ \\
\hline $31 / 03 / 2008$ & AT-401 & $\begin{array}{l}\text { Elaboração de diagnóstico da concepção } \\
\text { adotada do sistema existente para } \\
\text { elaboração de projeto da ampliação da } \\
\text { ETE Salesópolis }\end{array}$ & Cancelado & $\mathrm{R} \$ 88.500,00$ & $\mathrm{R} \$ 150.000,00$ \\
\hline $31 / 03 / 2008$ & AT-402 & $\begin{array}{l}\text { Capacitação para a educação ambiental } \\
\text { para o programa escola da família }\end{array}$ & Concluído & $\mathrm{R} \$ 79.430,34$ & $\mathrm{R} \$ 101.787,22$ \\
\hline $31 / 03 / 2008$ & AT-403 & $\begin{array}{l}\text { Ampliação da coleta seletiva Itapecerica } \\
\text { da Serra }\end{array}$ & Concluído & $\mathrm{R} \$ 108.000,00$ & $\mathrm{R} \$ 199.299,60$ \\
\hline $31 / 03 / 2008$ & AT-405 & $\begin{array}{l}\text { Plano de comunicação e de informação } \\
\text { para o CBH-AT }\end{array}$ & Cancelado & $\begin{array}{c}\mathrm{R} \$ \\
2.700 .000,00 \\
\end{array}$ & $\begin{array}{c}\mathrm{R} \$ \\
2.700 .000,00 \\
\end{array}$ \\
\hline $31 / 03 / 2008$ & AT-406 & $\begin{array}{l}\text { Levantamento, diagnóstico e avaliação } \\
\text { de projetos pelo FEHIDRO de anos } \\
\text { anteriores visando recomendações para } \\
\text { melhoria do sistema }\end{array}$ & Cancelado & $\mathrm{R} \$ 700.000,00$ & $\mathrm{R} \$ 700.000,00$ \\
\hline $31 / 03 / 2008$ & AT-409 & $\begin{array}{l}\text { Proteção da margem direita do córrego } \\
\text { da Av. Campo Grande, Bairro Nova Poá }\end{array}$ & Concluído & $\mathrm{R} \$ 469.269,44$ & $\mathrm{R} \$ 594.011,51$ \\
\hline $31 / 03 / 2008$ & AT-410 & $\begin{array}{l}\text { Implantação do programa de jovens da } \\
\text { reserva da biosfera para o município de } \\
\text { Embú }\end{array}$ & Concluído & $\mathrm{R} \$ 76.660,00$ & $\mathrm{R} \$ 181.260,00$ \\
\hline
\end{tabular}

Continua 


\section{ANEXO C - Síntese de projetos aprovados para recebimento de recursos financeiros do FEHIDRO}

Quadro 11 - Projetos aprovados que constam em deliberação do ano 2008.

Continuação

\begin{tabular}{|c|c|c|c|c|c|}
\hline $\begin{array}{c}\text { Data } \\
\text { deliberação }\end{array}$ & Código & Nome do empreendimento & Situação & $\begin{array}{c}\text { Valor } \\
\text { pleiteado }\end{array}$ & Valor total \\
\hline $31 / 03 / 2008$ & AT-411 & $\begin{array}{l}\text { Mapeamento das redes de esgoto e de } \\
\text { águas pluviais nas bacias do Poly e do } \\
\text { Judas nos bairros Alto Da Boa Vista e } \\
\text { Granja Julieta no distrito de Santo } \\
\text { Amaro pertencente à bacia Cotia- } \\
\text { Guarapiranga, bacia do Cordeiro e } \\
\text { córrego do Poly junto à bacia do } \\
\text { Jurubatuba, integrada à BH-AT }\end{array}$ & Concluído & $\mathrm{R} \$ 106.760,00$ & $\mathrm{R} \$ 155.720,00$ \\
\hline $31 / 03 / 2008$ & AT-413 & $\begin{array}{l}\text { Caminhos do rio Cotia - ações e } \\
\text { estratégias para educação ambiental }\end{array}$ & Cancelado & $\mathrm{R} \$ 173.522,00$ & $\mathrm{R} \$ 216.902,00$ \\
\hline $31 / 03 / 2008$ & AT-414 & $\begin{array}{l}\text { Programa de Educação Ambiental para } \\
\text { Alto Tietê - fase } 1 \text { - Produção do Atlas } \\
\text { de Recursos Hídricos do Alto Tietê } \\
\end{array}$ & Concluído & $\mathrm{R} \$ 239.204,70$ & $\mathrm{R} \$ 299.255,30$ \\
\hline $31 / 03 / 2008$ & AT-418 & $\begin{array}{l}\text { Cidadania verde - educação ambiental } \\
\text { para implementação da coleta seletiva }\end{array}$ & $\begin{array}{c}\text { Em } \\
\text { execução }\end{array}$ & $\mathrm{R} \$ 167.050,00$ & $\mathrm{R} \$ 268.386,00$ \\
\hline $31 / 03 / 2008$ & AT-419 & $\begin{array}{l}\text { Observatório do Programa mananciais } \\
\text { na bacia do Alto Tietê - sub-bacias } \\
\text { Guarapiranga e Billings }\end{array}$ & $\begin{array}{c}\text { Em } \\
\text { execução }\end{array}$ & $\mathrm{R} \$ 138.098,00$ & $\mathrm{R} \$ 193.376,88$ \\
\hline $31 / 03 / 2008$ & AT-421 & $\begin{array}{l}\text { Consolidação do Cadastro do DAEE e } \\
\text { da Cia de Tecnologia de Saneamento } \\
\text { Ambiental - CETESB para a } \\
\text { Implantação da Cobrança pelo Uso dos } \\
\text { Recursos Hídricos na UGRHI } 6 \\
\end{array}$ & Cancelado & $\begin{array}{c}\mathrm{R} \$ \\
1.600 .000,00\end{array}$ & $\begin{array}{c}\mathrm{R} \$ \\
1.600 .000,00\end{array}$ \\
\hline $31 / 03 / 2008$ & AT-422 & $\begin{array}{l}\text { Elaboração de Estudos e Serviços } \\
\text { Técnico em apoio em apoio à } \\
\text { implementação da cobrança pelo uso } \\
\text { dos Recursos Hídricos na UGRHI } 6\end{array}$ & Cancelado & $\mathrm{R} \$ 130.000,00$ & $\mathrm{R} \$ 130.000,00$ \\
\hline $31 / 03 / 2008$ & AT- 423 & $\begin{array}{l}\text { Sistema de alerta e controle de cheias do } \\
\text { município de Cajamar }\end{array}$ & Concluído & $\mathrm{R} \$ 103.530,00$ & $\mathrm{R} \$ 174.722,22$ \\
\hline $31 / 03 / 2008$ & AT-424 & $\begin{array}{l}\text { Plano de controle de cheias do ribeirão } \\
\text { dos Cristais e ribeirão dos Félix }\end{array}$ & Concluído & $\mathrm{R} \$ 150.000,00$ & $\mathrm{R} \$ 215.040,00$ \\
\hline $31 / 03 / 2008$ & AT-425 & $\begin{array}{l}\text { Elaboração de Plano de Manejo do } \\
\text { Parque Ecológico do Guarapiranga }\end{array}$ & Concluído & $\mathrm{R} \$ 46.440,00$ & $\mathrm{R} \$ 58.050,00$ \\
\hline $31 / 03 / 2008$ & AT-426 & $\begin{array}{l}\text { Fortalecimento do subcomitê Pinheiros: } \\
\text { comunicação institucional, integração e } \\
\text { mobilização social }\end{array}$ & Concluído & $\mathrm{R} \$ 232.104,80$ & $\mathrm{R} \$ 290.163,20$ \\
\hline $26 / 05 / 2008$ & AT-429 & $\begin{array}{l}\text { Diagnóstico da cobertura vegetal e } \\
\text { definição de estratégias para o } \\
\text { reflorestamento de áreas degradadas na } \\
\text { região de Paranapiacaba e Parque } \\
\text { Andreense (APRM) em Santo André }\end{array}$ & Concluído & $\mathrm{R} \$ 215.500,00$ & $\mathrm{R} \$ 326.216,70$ \\
\hline $26 / 05 / 2008$ & AT- 430 & $\begin{array}{l}\text { Plano de manejo participativo do parque } \\
\text { natural municipal nascentes de } \\
\text { Paranapiacaba, Santo André, São Paulo }\end{array}$ & Concluído & $\mathrm{R} \$ 171.880,00$ & $\mathrm{R} \$ 218.180,00$ \\
\hline
\end{tabular}

Fonte: FEHIDRO, 2017, compilado pela autora. 


\section{ANEXO C - Síntese de projetos aprovados para recebimento de recursos financeiros do FEHIDRO}

Quadro 12 - Projetos aprovados que constam em deliberação do ano 2009.

\begin{tabular}{|c|c|c|c|c|c|}
\hline $\begin{array}{c}\text { Data } \\
\text { deliberação }\end{array}$ & Código & Nome do empreendimento & Situação & $\begin{array}{c}\text { Valor } \\
\text { pleiteado }\end{array}$ & Valor total \\
\hline 20/07/2009 & AT-435 & $\begin{array}{l}\text { Quiz das águas - proposta de difusão } \\
\text { digital para o SIGRH }\end{array}$ & Cancelado & $\mathrm{R} \$ 290.124,50$ & $\mathrm{R} \$ 367.324,50$ \\
\hline 20/07/2009 & AT-436 & Coleta seletiva de atitude & Cancelado & $\mathrm{R} \$ 194.960,00$ & $\mathrm{R} \$ 243.700,00$ \\
\hline 20/07/2009 & AT-437 & $\begin{array}{l}\text { Avaliação do impacto dos efluentes } \\
\text { domésticos na qualidade das águas } \\
\text { subterrâneas na região de paranapiacaba } \\
\text { e parque andreense (APRM-Billings) no } \\
\text { município de Santo André }\end{array}$ & Concluído & $\mathrm{R} \$ 250.000,00$ & $\mathrm{R} \$ 315.853,72$ \\
\hline 20/07/2009 & AT-438 & $\begin{array}{l}\text { Projeto minha nascente - revitalização } \\
\text { dos corpos d'água na bacia do Alto Tietê } \\
\text { Cabeceiras }\end{array}$ & $\begin{array}{c}\text { Em } \\
\text { execução }\end{array}$ & $\mathrm{R} \$ 122.830,00$ & $\mathrm{R} \$ 172.930,00$ \\
\hline $20 / 07 / 2009$ & AT-439 & $\begin{array}{l}\text { Projeto gestão sustentável do meio } \\
\text { ambiente e dos recursos hídricos }\end{array}$ & $\begin{array}{c}\text { Em } \\
\text { execução }\end{array}$ & $\mathrm{R} \$ 241.166,64$ & $\mathrm{R} \$ 302.006,64$ \\
\hline 20/07/2009 & AT-441 & $\begin{array}{l}\text { Vida Limpa - educação ambiental, } \\
\text { inclusão social através da reciclagem }\end{array}$ & Cancelado & $\mathrm{R} \$ 133.540,80$ & $\mathrm{R} \$ 166.926,00$ \\
\hline 20/07/2009 & AT-446 & Turminha das águas & Cancelado & $\mathrm{R} \$ 182.860,80$ & $\mathrm{R} \$ 230.334,72$ \\
\hline 20/07/2009 & AT-451 & $\begin{array}{l}\text { Escola de formação ambiental Billings: } \\
\text { plano de educação ambiental para a } \\
\text { gestão e conservação dos recursos } \\
\text { hídricos }\end{array}$ & Concluído & $\mathrm{R} \$ 237.195,00$ & $\mathrm{R} \$ 608.034,62$ \\
\hline 20/07/2009 & AT-453 & $\begin{array}{l}\text { Comunicação e informação sobre } \\
\text { questões relacionadas aos recursos } \\
\text { hídricos da bacia hidrográfica do Alto } \\
\text { Tietê }\end{array}$ & Concluído & $\mathrm{R} \$ 112.424,40$ & $\mathrm{R} \$ 140.965,60$ \\
\hline 20/07/2009 & AT-454 & Adequação de estradas rurais & $\begin{array}{c}\text { Em } \\
\text { execução }\end{array}$ & $\mathrm{R} \$ 467.980,00$ & $\mathrm{R} \$ 585.110,00$ \\
\hline 20/07/2009 & AT-457 & $\begin{array}{l}\text { Diagnóstico socioambiental na APA } \\
\text { Embu verde: educação ambiental para } \\
\text { sustentabilidade na bacia do rio cotia }\end{array}$ & $\begin{array}{c}\text { Em } \\
\text { execução }\end{array}$ & $\mathrm{R} \$ 183.510,00$ & $\mathrm{R} \$ 244.270,00$ \\
\hline 20/07/2009 & AT-459 & \begin{tabular}{|l}
$\begin{array}{l}\text { Livro - história do Alto Tietê } \\
\text { despoluindo }\end{array}$ \\
\end{tabular} & Cancelado & $\mathrm{R} \$ 70.000,00$ & $\mathrm{R} \$ 100.000,00$ \\
\hline 20/07/2009 & AT-461 & \begin{tabular}{|l} 
Redescobrindo e despoluindo os \\
córregos do seu bairro - apoio ao \\
Programa Córrego Limpo-SABESP
\end{tabular} & Concluído & $\mathrm{R} \$ 186.940,00$ & $\mathrm{R} \$ 238.680,00$ \\
\hline 20/07/2009 & AT-463 & $\begin{array}{l}\text { De olho no óleo - despoluindo os } \\
\text { recursos hídricos e transformando } \\
\text { resíduos em fonte de energia }\end{array}$ & Concluído & $\mathrm{R} \$ 210.529,00$ & $\mathrm{R} \$ 299.529,00$ \\
\hline $11 / 09 / 2009$ & AT-464 & $\begin{array}{l}\text { Parque linear ecológico Jaguari - } \\
\text { recuperando áreas na bacia do Tietê- } \\
\text { leste }\end{array}$ & Concluído & $\mathrm{R} \$ 748.311,49$ & $\begin{array}{c}\mathrm{R} \$ \\
1.092 .455,54\end{array}$ \\
\hline 20/07/2009 & AT-468 & $\begin{array}{l}\text { Construção de um viveiro municipal de } \\
\text { mudas com espécies nativas e frutíferas, } \\
\text { promovendo o reflorestamento e a } \\
\text { recuperação de áreas de proteção } \\
\text { ambiental da sub-bacia Pinheiros- } \\
\text { Pirapora }\end{array}$ & Cancelado & $\mathrm{R} \$ 185.669,46$ & $\mathrm{R} \$ 235.024,64$ \\
\hline $20 / 07 / 2009$ & AT-469 & $\begin{array}{l}\text { Sustentabilidade de tratamentos de } \\
\text { esgotos domiciliares em comunidades } \\
\text { isoladas - projeto piloto: Vila Machado }\end{array}$ & Concluído & $\mathrm{R} \$ 74.423,42$ & $\mathrm{R} \$ 94.213,84$ \\
\hline
\end{tabular}




\section{ANEXO C - Síntese de projetos aprovados para recebimento de recursos financeiros do FEHIDRO}

Quadro 12 - Projetos aprovados que constam em deliberação do ano 2009.

Continuação

\begin{tabular}{|c|c|c|c|c|c|}
\hline $\begin{array}{c}\text { Data } \\
\text { deliberação }\end{array}$ & Código & Nome do empreendimento & Situação & $\begin{array}{c}\text { Valor } \\
\text { pleiteado }\end{array}$ & Valor total \\
\hline 20/07/2009 & AT -470 & $\begin{array}{l}\text { SIG para a sub-bacia do rio Embu- } \\
\text { Mirim }\end{array}$ & Concluído & $\mathrm{R} \$ 143.778,00$ & $\mathrm{R} \$ 180.156,00$ \\
\hline 20/07/2009 & AT -473 & $\begin{array}{l}\text { Programa de conservação e proteção de } \\
\text { corpos hídricos } \quad \text { nascentes do } \\
\text { Guarapiranga }\end{array}$ & Concluído & $\mathrm{R} \$ 173.320,60$ & $\mathrm{R} \$ 240.951,54$ \\
\hline 20/07/2009 & AT-474 & $\begin{array}{l}\text { Estudos e projetos de remediação do } \\
\text { antigo vazadouro de resíduos sólidos } \\
\text { domiciliares de Caieiras }\end{array}$ & Concluído & $\mathrm{R} \$ 249.095,00$ & $\mathrm{R} \$ 355.795,00$ \\
\hline 20/07/2009 & AT-475 & $\begin{array}{l}\text { Caracterização das águas do Alto Tietê } \\
\text { em relação a presença de cianobactérias } \\
\text { e toxicidade nos organismos aquáticos }\end{array}$ & Concluído & $\mathrm{R} \$ 207.262,00$ & $\mathrm{R} \$ 320.946,64$ \\
\hline $20 / 07 / 2009$ & AT-477 & $\begin{array}{l}\text { Capacitação em gestão de contratos } \\
\text { referentes a projetos contidos no plano } \\
\text { da bacia hidrográfica do Alto Tietê e } \\
\text { financiados pelo fundo estadual de } \\
\text { recursos hídricos }\end{array}$ & Concluído & $\mathrm{R} \$ 247.590,72$ & $\mathrm{R} \$ 247.590,72$ \\
\hline 20/07/2009 & AT -478 & $\begin{array}{l}\text { Relatório de situação dos recursos } \\
\text { hídricos da bacia hidrográfica do Alto } \\
\text { Tietê no ano de } 2008\end{array}$ & Concluído & $\mathrm{R} \$ 450.000,00$ & $\mathrm{R} \$ 450.000,00$ \\
\hline 20/07/2009 & AT-479 & $\begin{array}{l}\text { Plano de desenvolvimento regional dos } \\
\text { mananciais do subcomitê alto tietê } \\
\text { cabeceiras: PDPA - e assessoria para } \\
\text { elaboração das leis específicas }\end{array}$ & Cancelado & $\mathrm{R} \$ 500.000,00$ & $\mathrm{R} \$ 625.000,00$ \\
\hline 20/07/2009 & AT -480 & $\begin{array}{l}\text { Plano diretor regional da sub-região } \\
\text { Juquery-Cantareira - complementação: } \\
\text { indicação das áreas de intervenção e } \\
\text { respectivas leis específicas para os } \\
\text { compartimentos Itaim e Alto Cristais }\end{array}$ & Cancelado & $\mathrm{R} \$ 120.000,00$ & $\mathrm{R} \$ 120.000,00$ \\
\hline 20/07/2009 & AT -482 & $\begin{array}{l}\text { Planos municipais de saneamento } \\
\text { ambiental para os municípios de } \\
\text { Mairiporã, Francisco Morato, Franco da } \\
\text { Rocha, Caieiras e Cajamar }\end{array}$ & Cancelado & $\mathrm{R} \$ 576.400,00$ & $\mathrm{R} \$ 576.400,00$ \\
\hline 20/07/2009 & AT -483 & $\begin{array}{l}\text { Cidadania verde Ii - educação ambiental } \\
\text { para implementação da coleta seletiva }\end{array}$ & Cancelado & $\mathrm{R} \$ 120.120,00$ & $\mathrm{R} \$ 180.442,00$ \\
\hline 20/07/2009 & AT-484 & $\begin{array}{l}\text { Inserção da educação ambiental nas } \\
\text { escolas, cuidando das microbacias do } \\
\text { município de Cajamar, na sub-bacia } \\
\text { Juquery-Cantareira }\end{array}$ & Concluído & $\mathrm{R} \$ 313.300,00$ & $\mathrm{R} \$ 391.810,00$ \\
\hline 20/07/2009 & AT-485 & $\begin{array}{l}\text { Mapeamento dos pontos de alagamento } \\
\text { e inundação do município de São Paulo }\end{array}$ & $\begin{array}{c}\text { Em } \\
\text { execução }\end{array}$ & $\mathrm{R} \$ 249.970,00$ & $\mathrm{R} \$ 298.450,00$ \\
\hline 20/07/2009 & AT-486 & $\begin{array}{l}\text { Elaboração de manual para projetos } \\
\text { integrados de sistemas de águas pluviais } \\
\text { e esgotos sanitários }\end{array}$ & $\begin{array}{c}\text { Em } \\
\text { execução }\end{array}$ & $\mathrm{R} \$ 106.600,00$ & $\mathrm{R} \$ 133.600,00$ \\
\hline
\end{tabular}

Continua 


\section{ANEXO C - Síntese de projetos aprovados para recebimento de recursos financeiros do FEHIDRO}

Quadro 12 - Projetos aprovados que constam em deliberação do ano 2009.

Continuação

\begin{tabular}{|c|c|c|c|c|c|}
\hline $\begin{array}{c}\text { Data } \\
\text { deliberação }\end{array}$ & Código & Nome do empreendimento & Situação & $\begin{array}{c}\text { Valor } \\
\text { pleiteado }\end{array}$ & Valor total \\
\hline $20 / 07 / 2009$ & AT-487 & $\begin{array}{l}\text { Atualização da } \text { infraestrutura } \\
\text { tecnológica da sede }- \text { cidade } \\
\text { universitária - da rede hidrológica básica } \\
\text { do estado de S.P. }\end{array}$ & Concluído & $\mathrm{R} \$ 57.500,00$ & $\mathrm{R} \$ 57.500,00$ \\
\hline 20/07/2009 & AT-488 & $\begin{array}{l}\text { Via verde - recuperação de áreas } \\
\text { degradadas e produção de mudas } \\
\text { florestais nativas - fase I }\end{array}$ & Concluído & $\mathrm{R} \$ 167.410,86$ & $\mathrm{R} \$ 213.705,86$ \\
\hline $11 / 09 / 2009$ & AT-490 & $\begin{array}{l}\text { Via verde - recuperação de áreas } \\
\text { degradadas e produção de mudas } \\
\text { florestais nativas -fase II }\end{array}$ & Concluído & $\mathrm{R} \$ 131.796,85$ & $\mathrm{R} \$ 195.083,85$ \\
\hline 20/07/2009 & AT-493 & Juca vivo - bióleo & Cancelado & $\mathrm{R} \$ 244.768,00$ & $\mathrm{R} \$ 306.768,00$ \\
\hline $20 / 07 / 2009$ & AT-494 & $\begin{array}{l}\text { Disposição correta de óleo de cozinha } \\
\text { na bacia do Alto Tiête - } \\
\text { Billings/Tamanduatei; geração de } \\
\text { ocupação e renda, oportunidade } \\
\text { socioambiental em Ribeirão Pires }\end{array}$ & $\begin{array}{c}\text { Em } \\
\text { execução }\end{array}$ & $\mathrm{R} \$ 134.104,00$ & $\mathrm{R} \$ 170.122,00$ \\
\hline 20/07/2009 & AT -495 & $\begin{array}{l}\text { Construção de locais de entrega } \\
\text { voluntaria de resíduos sólidos -lev no } \\
\text { município de Ribeirão Pires, localizado } \\
\text { na sub-bacia Billings da bacia } \\
\text { hidrográfica do Alto Tiete }\end{array}$ & Cancelado & $\mathrm{R} \$ 499.893,42$ & $\mathrm{R} \$ 627.686,73$ \\
\hline $20 / 07 / 2009$ & AT-496 & $\begin{array}{l}\text { Programa cílios da represa Billings } \\
\text { (CBH-AT-BT), elaboração de } \\
\text { instrumentos legais, e implantação de } \\
\text { políticas públicas para gestão, } \\
\text { conservação e proteção de mananciais } \\
\text { superficiais em Ribeirão Pires }\end{array}$ & Cancelado & $\mathrm{R} \$ 114.369,80$ & $\mathrm{R} \$ 169.711,56$ \\
\hline $11 / 09 / 2009$ & AT -497 & $\begin{array}{l}\text { Recuperação da mata ciliar em nascente, } \\
\text { córrego, lago e canal de drenagem no } \\
\text { campus capital da USP }\end{array}$ & $\begin{array}{c}\text { Em } \\
\text { execução }\end{array}$ & $\mathrm{R} \$ 239.129,55$ & $\mathrm{R} \$ 350.367,40$ \\
\hline $18 / 09 / 2009$ & AT-499 & $\begin{array}{l}\text { Apoio à adequação da infraestrutura da } \\
\text { secretaria executiva do CBH-AT e dos } 5 \\
\text { subcomitês }\end{array}$ & $\begin{array}{c}\text { Em } \\
\text { execução }\end{array}$ & $\mathrm{R} \$ 206.000,64$ & $\mathrm{R} \$ 206.000,64$ \\
\hline $18 / 09 / 2009$ & AT-500 & $\begin{array}{l}\text { Novos procedimentos para drenagem de } \\
\text { estruturas subterrâneas }\end{array}$ & $\begin{array}{c}\text { Em } \\
\text { execução }\end{array}$ & $\mathrm{R} \$ 90.000,00$ & $\mathrm{R} \$ 112.500,00$ \\
\hline
\end{tabular}

Fonte: FEHIDRO, 2017, compilado pela autora. 


\section{ANEXO C - Síntese de projetos aprovados para recebimento de recursos financeiros do FEHIDRO}

Quadro 13 - Projetos aprovados que constam em deliberação do ano 2010.

\begin{tabular}{|c|c|c|c|c|c|}
\hline $\begin{array}{c}\text { Data } \\
\text { deliberação }\end{array}$ & Código & Nome do empreendimento & Situação & $\begin{array}{c}\text { Valor } \\
\text { pleiteado }\end{array}$ & Valor total \\
\hline $26 / 05 / 2010$ & AT-503 & $\begin{array}{c}\text { Elaboração do Plano Diretor de } \\
\text { Drenagem do município de Salesópolis }\end{array}$ & $\begin{array}{c}\text { Em } \\
\text { execução }\end{array}$ & $\mathrm{R} \$ 118.792,13$ & $\mathrm{R} \$ 148.490,16$ \\
\hline $26 / 05 / 2010$ & AT-515 & $\begin{array}{c}\text { Núcleo de audiovisual para registro e } \\
\text { divulgação dos empreendimentos, ações } \\
\text { e atividades do subcomitê Pinheiros- } \\
\text { Pirapora }\end{array}$ & Cancelado & $\mathrm{R} \$ 140.213,34$ & $\mathrm{R} \$ 184.399,94$ \\
\hline $26 / 05 / 2010$ & AT-516 & $\begin{array}{c}\text { Implantação do programa de uso } \\
\text { racional da água - pura, em próprios } \\
\text { municipais do tipo escolas e unidades de } \\
\text { saúde }\end{array}$ & Cancelado & $\mathrm{R} \$ 596.424,42$ & $\mathrm{R} \$ 627.815,20$ \\
\hline $26 / 05 / 2010$ & AT-518 & $\begin{array}{l}\text { Escola piloto em educação ambiental: } \\
\text { escola eco sustentável, escola Palmira } \\
\text { Antônio pereira, E.M.,Sito a rua } \\
\text { Emerson C. S. Giacomino, } 200 \text { - Jd. } \\
\text { Aymoré } \\
\end{array}$ & $\begin{array}{c}\text { Em } \\
\text { execução }\end{array}$ & $\mathrm{R} \$ 103.613,34$ & $\mathrm{R} \$ 132.837,61$ \\
\hline $26 / 05 / 2010$ & AT-520 & $\begin{array}{c}\text { Elaboração de plano diretor de } \\
\text { drenagem do município de Biritiba } \\
\text { Mirim } \\
\end{array}$ & $\begin{array}{c}\text { Em } \\
\text { execução }\end{array}$ & $\mathrm{R} \$ 118.435,20$ & $\mathrm{R} \$ 148.044,00$ \\
\hline $26 / 05 / 2010$ & AT-523 & $\begin{array}{c}\text { Agroecologia como estratégia de } \\
\text { preservação e recuperação dos } \\
\text { mananciais da Guarapiranga e do Alto } \\
\text { Cotia }\end{array}$ & Cancelado & $\mathrm{R} \$ 98.404,00$ & $\mathrm{R} \$ 123.496,00$ \\
\hline $26 / 05 / 2010$ & AT-526 & $\begin{array}{c}\text { Projeto para manutenção da rede de } \\
\text { monitoramento automático da qualidade } \\
\text { das águas superficiais da sub-bacia } \\
\text { Juqueri-Cantareira }\end{array}$ & Concluído & $\mathrm{R} \$ 118.518,60$ & $\mathrm{R} \$ 149.080,00$ \\
\hline $26 / 05 / 2010$ & AT-527 & $\begin{array}{l}\text { Implantação do programa do uso } \\
\text { racional da água - PURA }\end{array}$ & $\begin{array}{c}\text { Em } \\
\text { execução }\end{array}$ & $\mathrm{R} \$ 678.019,06$ & $\mathrm{R} \$ 713.704,27$ \\
\hline $26 / 05 / 2010$ & AT-528 & $\begin{array}{c}\text { Empreendimento, implantação } \\
\text { Programa de Uso Racional da Água em } \\
\text { entidades do tipo escolas e unidades de } \\
\text { saúde }\end{array}$ & Concluído & $\mathrm{R} \$ 681.488,60$ & $\mathrm{R} \$ 717.356,42$ \\
\hline $26 / 05 / 2010$ & AT-531 & Programa de Uso Racional da Água & $\begin{array}{c}\text { Em } \\
\text { execução }\end{array}$ & $\mathrm{R} \$ 666.387,26$ & $\mathrm{R} \$ 701.460,27$ \\
\hline $26 / 05 / 2010$ & AT-533 & $\begin{array}{l}\text { Subsídios e estudos para formulação de } \\
\text { manual de boas práticas em } \\
\text { assentamentos urbanos da APRM de } \\
\text { São Bernardo do Campo }\end{array}$ & Concluído & $\mathrm{R} \$ 348.033,03$ & $\mathrm{R} \$ 387.433,59$ \\
\hline $26 / 05 / 2010$ & AT-537 & $\begin{array}{l}\text { Subsídios para o enquadramento dos } \\
\text { corpos d'água na bacia do Alto Tietê }\end{array}$ & $\begin{array}{c}\text { Em } \\
\text { execução }\end{array}$ & $\mathrm{R} \$ 650.000,00$ & $\mathrm{R} \$ 812.500,00$ \\
\hline $26 / 05 / 2010$ & AT -540 & $\begin{array}{c}\text { Água é Vida: educação ambiental para a } \\
\text { proteção compartilhada do rio } \\
\text { Guarapiranga }\end{array}$ & Cancelado & $\mathrm{R} \$ 312.234,00$ & $\mathrm{R} \$ 395.434,00$ \\
\hline $26 / 05 / 2010$ & AT-542 & $\begin{array}{c}\text { Mapeamento de áreas com potenciais } \\
\text { riscos de contaminação das águas } \\
\text { subterrâneas na UGHI } 6 \text { e suas regiões } \\
\text { de recarga }\end{array}$ & Concluído & $\mathrm{R} \$ 690.000,00$ & $\mathrm{R} \$ 690.000,00$ \\
\hline
\end{tabular}

Continua 


\section{ANEXO C - Síntese de projetos aprovados para recebimento de recursos financeiros do FEHIDRO}

Quadro 13 - Projetos aprovados que constam em deliberação do ano 2010.

Continuação

\begin{tabular}{|c|c|c|c|c|c|}
\hline $26 / 05 / 2010$ & AT-543 & $\begin{array}{c}\text { Análise da qualidade da água utilizada } \\
\text { na atividade agrícola, no município de } \\
\text { Mogi das Cruzes }\end{array}$ & $\begin{array}{c}\text { Em } \\
\text { execução }\end{array}$ & $\mathrm{R} \$ 95.815,00$ & $\mathrm{R} \$ 136.222,00$ \\
\hline $26 / 05 / 2010$ & AT-544 & $\begin{array}{c}\text { Desenvolvimento de medidor de vazão } \\
\text { de baixo custo }\end{array}$ & Concluído & $\mathrm{R} \$ 225.000,00$ & $\mathrm{R} \$ 225.000,00$ \\
\hline $26 / 05 / 2010$ & AT-545 & $\begin{array}{c}\text { Portal hidrológico da bacia do Alto } \\
\text { Tietê }\end{array}$ & $\begin{array}{c}\text { Em } \\
\text { execução }\end{array}$ & $\mathrm{R} \$ 125.000,00$ & $\mathrm{R} \$ 125.000,00$ \\
\hline $18 / 11 / 2010$ & AT-548 & $\begin{array}{c}\text { Adequação de estradas rurais no } \\
\text { município de Mogi das Cruzes, comitê } \\
\text { de BH-AT, subcomitê de bacia } \\
\text { hidrográfica Alto Tietê-Cabeceiras }\end{array}$ & Concluído & $\mathrm{R} \$ 709.961,57$ & $\mathrm{R} \$ 888.551,40$ \\
\hline
\end{tabular}

Fonte: FEHIDRO, 2017, compilado pela autora. 


\section{ANEXO C - Síntese de projetos aprovados para recebimento de recursos financeiros do FEHIDRO}

Quadro 14 - Projetos aprovados que constam em deliberação do ano 2011.

\begin{tabular}{|c|c|c|c|c|c|}
\hline $\begin{array}{c}\text { Data } \\
\text { deliberação }\end{array}$ & Código & Nome do empreendimento & Situação & $\begin{array}{c}\text { Valor } \\
\text { pleiteado }\end{array}$ & Valor total \\
\hline $30 / 06 / 2011$ & AT-551 & Represa Billings: visão e ação & Cancelado & $\mathrm{R} \$ 403.578,00$ & $\mathrm{R} \$ 448.578,00$ \\
\hline $16 / 02 / 2011$ & AT-553 & $\begin{array}{l}\text { Plano de desenvolvimento regional dos } \\
\text { mananciais do subcomitê Alto Tietê- } \\
\text { Cabeceiras: PDPA e assessoria para } \\
\text { elaboração das leis específicas }\end{array}$ & Concluído & $\mathrm{R} \$ 500.000,00$ & $\mathrm{R} \$ 500.000,00$ \\
\hline $30 / 06 / 2011$ & AT-557 & $\begin{array}{l}\text { Plano de manejo da Apa Embu Verde - } \\
\text { zoneamento ambiental participativo na } \\
\text { bacia do rio Cotia }\end{array}$ & $\begin{array}{c}\text { Em } \\
\text { execução }\end{array}$ & $\mathrm{R} \$ 268.099,60$ & $\mathrm{R} \$ 337.100,40$ \\
\hline $30 / 06 / 2011$ & AT-563 & $\begin{array}{l}\text { Rios do nosso lugar: conhecendo e } \\
\text { cuidando dos recursos hídricos do Alto } \\
\text { Tietê-Cabeceiras }\end{array}$ & Concluído & $\mathrm{R} \$ 454.098,00$ & $\mathrm{R} \$ 504.558,00$ \\
\hline $30 / 06 / 2011$ & AT-569 & Mairiporã - água e socioambiente & Cancelado & $\mathrm{R} \$ 261.802,66$ & $\mathrm{R} \$ 351.716,41$ \\
\hline $30 / 06 / 2011$ & AT-573 & $\begin{array}{l}\text { Escola flutuante -práticas de educação } \\
\text { ambiental (represa Billings e APA } \\
\text { Bororé-Colônia) }\end{array}$ & Cancelado & $\mathrm{R} \$ 234.421,00$ & $\mathrm{R} \$ 293.071,00$ \\
\hline 13/07/2011 & AT-574 & $\begin{array}{l}\text { Plano de comunicação e de informação } \\
\text { para o CBH-AT }\end{array}$ & Concluído & $\begin{array}{c}\mathrm{R} \$ \\
2.699 .996,00 \\
\end{array}$ & $\begin{array}{c}\mathrm{R} \$ \\
2.699 .996,00\end{array}$ \\
\hline 06/10/2011 & AT-575 & Escola Selo Verde & Cancelado & $\mathrm{R} \$ 362.786,02$ & $\mathrm{R} \$ 465.110,25$ \\
\hline 06/10/2011 & AT-584 & $\begin{array}{l}\text { Toxicidade e genotoxicidade de água } \\
\text { intersticial proveniente de sedimentos } \\
\text { na unidade de gerenciamento de } \\
\text { recursos hídricos do Alto Tietê (UGRHI } \\
6 \text { ) }\end{array}$ & $\begin{array}{c}\text { Em } \\
\text { execução }\end{array}$ & $\mathrm{R} \$ 454.100,00$ & $\mathrm{R} \$ 788.008,33$ \\
\hline $06 / 10 / 2011$ & AT-586 & $\begin{array}{l}\text { Desenvolvimento sustentável em áreas } \\
\text { de mananciais - diagnóstico e propostas; } \\
\text { levantamento e desenvolvimento de } \\
\text { ações a serem contempladas por } \\
\text { pagamentos de serviços ambientais - } \\
\text { PSA, em áreas de pro... }\end{array}$ & Cancelado & $\mathrm{R} \$ 906.573,74$ & $\mathrm{R} \$ 950.598,74$ \\
\hline
\end{tabular}

Fonte: FEHIDRO, 2017, compilado pela autora. 
ANEXO C - Síntese de projetos aprovados para recebimento de recursos financeiros do FEHIDRO

Quadro 15 - Projetos aprovados que constam em deliberação do ano 2012.

\begin{tabular}{|c|c|c|c|c|c|}
\hline $\begin{array}{c}\text { Data } \\
\text { deliberação }\end{array}$ & Código & Nome do empreendimento & Situação & $\begin{array}{c}\text { Valor } \\
\text { pleiteado }\end{array}$ & Valor total \\
\hline $28 / 11 / 2012$ & AT-603 & $\begin{array}{l}\text { Avaliação da contaminação ambiental } \\
\text { por metais pesados nos compartimentos } \\
\text { água, sedimento e peixes dos } \\
\text { reservatórios da UGRHI 6. }\end{array}$ & $\begin{array}{c}\text { Em } \\
\text { execução }\end{array}$ & $\begin{array}{c}\mathrm{R} \$ \\
1.300 .000,00\end{array}$ & $\begin{array}{c}\mathrm{R} \$ \\
1.629 .026,20\end{array}$ \\
\hline $28 / 11 / 2012$ & AT-604 & $\begin{array}{l}\text { Atualização de metodologias analíticas } \\
\text { para avaliação e monitoramento dos } \\
\text { impactos dos efluentes dispostos nas } \\
\text { águas superficiais da BH-AT - São } \\
\text { Paulo }\end{array}$ & $\begin{array}{c}\text { Em } \\
\text { execução }\end{array}$ & $\mathrm{R} \$ 445.000,00$ & $\mathrm{R} \$ 498.015,00$ \\
\hline
\end{tabular}

Fonte: FEHIDRO, 2017, compilado pela autora. 


\section{ANEXO C - Síntese de projetos aprovados para recebimento de recursos financeiros do FEHIDRO}

Quadro 16 - Projetos aprovados que constam em deliberação do ano 2013.

\begin{tabular}{|c|c|c|c|c|c|}
\hline $\begin{array}{c}\text { Data } \\
\text { deliberação }\end{array}$ & Código & Nome do empreendimento & Situação & Valor pleiteado & Valor total \\
\hline $01 / 10 / 2013$ & $\begin{array}{l}\text { AT- } \\
619\end{array}$ & $\begin{array}{l}\text { Programa de uso racional da água } \\
\text { (PURA) em escolas públicas }\end{array}$ & Cancelado & $\mathrm{R} \$ 4.995 .000,00$ & $\mathrm{R} \$ 4.995 .000,00$ \\
\hline $01 / 10 / 2013$ & $\begin{array}{l}\text { AT- } \\
623\end{array}$ & $\begin{array}{l}\text { Avaliação de indicações, proposta } \\
\text { de novos critérios r de } \\
\text { hierarquização e sistema de } \\
\text { acompanhamento da execução dos } \\
\text { empreendimentos FEHIDRO } \\
\end{array}$ & Cancelado & $\mathrm{R} \$ 600.000,00$ & $\mathrm{R} \$ 600.000,00$ \\
\hline $01 / 10 / 2013$ & $\begin{array}{l}\text { AT- } \\
626 \\
\end{array}$ & $\begin{array}{l}\text { Plano da bacia hidrográfica do } \\
\text { Alto Tietê (UGRHI 6) }\end{array}$ & $\begin{array}{c}\text { Em } \\
\text { execução }\end{array}$ & $\mathrm{R} \$ 3.999 .628,80$ & $\mathrm{R} \$ 3.999 .628,80$ \\
\hline $01 / 10 / 2013$ & $\begin{array}{l}\text { AT- } \\
628\end{array}$ & $\begin{array}{l}\text { Construção de galpão e aquisição } \\
\text { de equipamentos para ampliação } \\
\text { da coleta seletiva na sub-bacia } \\
\text { Taiaçupeba }\end{array}$ & $\begin{array}{c}\text { Em } \\
\text { execução }\end{array}$ & $\mathrm{R} \$ 372.000,00$ & $\mathrm{R} \$ 483.260,55$ \\
\hline 01/10/2013 & $\begin{array}{l}\text { AT- } \\
629\end{array}$ & $\begin{array}{l}\text { Mapeamento sistemático e } \\
\text { temático de uso e ocupação do } \\
\text { solo, da BH-AT e da RMSP }\end{array}$ & $\begin{array}{c}\text { Em } \\
\text { execução }\end{array}$ & $\mathrm{R} \$ 14.200 .000,00$ & $\mathrm{R} \$ 14.200 .000,00$ \\
\hline
\end{tabular}

Fonte: FEHIDRO, 2017, compilado pela autora. 


\section{ANEXO C - Síntese de projetos aprovados para recebimento de recursos financeiros do FEHIDRO}

Quadro 17 - Projetos aprovados que constam em deliberação do ano 2014.

\begin{tabular}{|c|c|c|c|c|c|}
\hline $\begin{array}{c}\text { Data } \\
\text { deliberação }\end{array}$ & Código & Nome do empreendimento & Situação & Valor pleiteado & Valor total \\
\hline $26 / 05 / 2014$ & $\begin{array}{l}\text { AT- } \\
630 \\
\end{array}$ & $\begin{array}{l}\text { Programa de uso racional da água } \\
\text { e telemedição (PURA) }\end{array}$ & $\begin{array}{c}\text { Em } \\
\text { execução }\end{array}$ & $\mathrm{R} \$ 4.982 .716,74$ & $\mathrm{R} \$ 4.982 .716,74$ \\
\hline $23 / 09 / 2014$ & $\begin{array}{l}\text { AT- } \\
634\end{array}$ & $\begin{array}{l}\text { Programa de uso racional da água } \\
\text { e telemedição (PURA) em escolas } \\
\text { da rede estadual de ensino } \\
\text { abastecidas pelos sistemas } \\
\text { Cantareira e Alto Tietê }\end{array}$ & $\begin{array}{c}\text { Em } \\
\text { execução }\end{array}$ & $\mathrm{R} \$ 1.932 .269,40$ & $\mathrm{R} \$ 3.220 .448,97$ \\
\hline $23 / 09 / 2014$ & $\begin{array}{l}\text { AT- } \\
640\end{array}$ & $\begin{array}{l}\text { Subsídios a elaboração do plano } \\
\text { de macrodrenagem da bacia do rio } \\
\text { cotia e do município de Cotia - } \\
\text { parte I }\end{array}$ & $\begin{array}{c}\text { Em } \\
\text { execução }\end{array}$ & $\mathrm{R} \$ 360.010,60$ & $\mathrm{R} \$ 403.510,60$ \\
\hline $23 / 09 / 2014$ & $\begin{array}{l}\text { AT- } \\
650\end{array}$ & $\begin{array}{l}\text { Programa de comunicação visual } \\
\text { nas áreas de proteção e } \\
\text { recuperação de mananciais - } \\
\text { Billings - Grande ABC }\end{array}$ & Cancelado & $\mathrm{R} \$ 659.320,70$ & $\mathrm{R} \$ 732.606,86$ \\
\hline $23 / 09 / 2014$ & $\begin{array}{l}\text { AT- } \\
653\end{array}$ & $\begin{array}{l}\text { Desenvolvimento de metodologia } \\
\text { e projeto piloto de revitalização de } \\
\text { bacia urbana (córrego Jaguaré, } \\
\text { município de São Paulo) }\end{array}$ & $\begin{array}{c}\text { Em } \\
\text { execução }\end{array}$ & $\mathrm{R} \$ 1.500 .000,00$ & $\mathrm{R} \$ 1.667 .061,30$ \\
\hline $23 / 09 / 2014$ & $\begin{array}{l}\text { AT- } \\
654\end{array}$ & $\begin{array}{l}\text { Redução do consumo de água em } \\
\text { escolas de cidades integrantes do } \\
\text { CIOESTE }\end{array}$ & $\begin{array}{c}\text { Em } \\
\text { execução }\end{array}$ & $\mathrm{R} \$ 796.059,67$ & $\mathrm{R} \$ 1.015 .059,67$ \\
\hline $23 / 09 / 2014$ & $\begin{array}{l}\text { AT- } \\
656\end{array}$ & $\begin{array}{l}\text { Avaliação da presença de } \\
\text { poluentes orgânicos persistentes } \\
\text { (POPS) e metais pesados nas } \\
\text { águas, sedimentos e organismos } \\
\text { aquáticos da UGRHI } 6\end{array}$ & $\begin{array}{c}\text { Em } \\
\text { execução }\end{array}$ & $\mathrm{R} \$ 2.878 .656,00$ & $\mathrm{R} \$ 3.334 .371,00$ \\
\hline
\end{tabular}

Fonte: FEHIDRO, 2017, compilado pela autora. 
ANEXO C - Síntese de projetos aprovados para recebimento de recursos financeiros do FEHIDRO

Quadro 18 - Projetos aprovados que constam em deliberação do ano 2015.

\begin{tabular}{|c|c|c|c|c|c|}
\hline $\begin{array}{c}\text { Data } \\
\text { deliberação }\end{array}$ & Código & Nome do empreendimento & Situação & Valor pleiteado & Valor total \\
\hline $16 / 07 / 2015$ & $\begin{array}{l}\text { AT- } \\
672\end{array}$ & $\begin{array}{l}\text { Delimitação de áreas de restrição } \\
\text { e controle da captação e uso das } \\
\text { águas subterrâneas da bacia } \\
\text { hidrográfica do rio Baquirivu- } \\
\text { Guaçu e porção sedimentar do } \\
\text { entorno leste, municípios de } \\
\text { Guarulhos e Arujá }\end{array}$ & $\begin{array}{c}\text { Em } \\
\text { execução }\end{array}$ & $\mathrm{R} \$ 1.500 .000,00$ & $\mathrm{R} \$ 1.500 .000,00$ \\
\hline
\end{tabular}

Fonte: FEHIDRO, 2017, compilado pela autora. 


\section{ANEXO C - Síntese de projetos aprovados para recebimento de recursos financeiros do FEHIDRO}

Quadro 19 - Projetos aprovados que constam em deliberação do ano 2016.

\begin{tabular}{|c|c|c|c|c|c|}
\hline $\begin{array}{c}\text { Data } \\
\text { deliberação }\end{array}$ & Código & Nome do empreendimento & Situação & Valor pleiteado & Valor total \\
\hline $28 / 06 / 2016$ & $\begin{array}{l}\text { AT- } \\
677\end{array}$ & $\begin{array}{l}\text { Elaboração do plano diretor de } \\
\text { abastecimento de água do } \\
\text { município de Santo André }\end{array}$ & Em análise & $\mathrm{R} \$ 1.477 .986,96$ & $\mathrm{R} \$ 1.847 .483,70$ \\
\hline $28 / 06 / 2016$ & $\begin{array}{l}\text { AT- } \\
678\end{array}$ & Caieiras e suas nascentes & Em análise & $\mathrm{R} \$ 1.405 .712,56$ & $\mathrm{R} \$ 1.561 .902,89$ \\
\hline $28 / 06 / 2016$ & $\begin{array}{l}\text { AT- } \\
679\end{array}$ & $\begin{array}{l}\text { Investigação detalhada de } \\
\text { contaminação e avaliação de risco } \\
\text { à saúde humana do antigo lixão da } \\
\text { Volta Fria }\end{array}$ & Em análise & $\mathrm{R} \$ 606.579,72$ & $\mathrm{R} \$ 677.995,72$ \\
\hline $28 / 06 / 2016$ & $\begin{array}{l}\text { AT- } \\
680\end{array}$ & $\begin{array}{l}\text { Avaliação ambiental preliminar e } \\
\text { investigação confirmatória de } \\
\text { contaminação da antiga usina de } \\
\text { siderúrgica de Mogi das Cruzes }\end{array}$ & Em análise & $\mathrm{R} \$ 502.521,00$ & $\mathrm{R} \$ 561.771,00$ \\
\hline $28 / 06 / 2016$ & $\begin{array}{l}\text { AT- } \\
684\end{array}$ & $\begin{array}{l}\text { Adequação e melhoria da estrada } \\
\text { da moralogia no município de } \\
\text { Mogi das Cruzes }\end{array}$ & $\begin{array}{c}\text { Não } \\
\text { iniciado }\end{array}$ & $\mathrm{R} \$ 650.222,73$ & $\mathrm{R} \$ 812.778,41$ \\
\hline $28 / 06 / 2016$ & $\begin{array}{l}\text { AT- } \\
689\end{array}$ & $\begin{array}{l}\text { Obra do sistema de esgotamento } \\
\text { sanitário no município de São } \\
\text { Paulo - EEE Caiubá, na bacia } \\
\text { hidrográfica do Alto Tiete }\end{array}$ & Em análise & $\mathrm{R} \$ 1.596 .747,14$ & $\mathrm{R} \$ 2.001 .425,12$ \\
\hline
\end{tabular}

Fonte: FEHIDRO, 2017, compilado pela autora. 